The Aporia of Equality 



\section{The Aporia of Equality}

A Historico-Political Approach to Swedish

Educational Politics 1946-2000

Tomas Wedin 
(C) Tomas Wedin

$\begin{aligned} & \text { Centre for Educational } \\ & \text { and Teacher Research }\end{aligned} \quad$ and $\quad \begin{aligned} & \text { Department of Literature, } \\ & \text { History of ideas, and Religion }\end{aligned}$

University of Gothenburg

Box 200

40530 Gothenburg

CUL Graduate school in educational science, doctoral thesis 72 .

In 2004 the University of Gothenburg established the Centre for Educational Science and Teacher Research (CUL). CUL aims to promote and support research and third-cycle studies linked to the teaching profession and the teacher training programme. The graduate school is an interfaculty initiative carried out jointly by the Faculties involved in the teacher training programme at the University of Gothenburg and in cooperation with municipalities, school governing bodies and university colleges. www.cul.gu.se

Reproduktion: Repro Lorensberg

Omslagsbild: J. M. W. Turner, "Rain, Steam and Speed - The Great Western Railway", 1844

Turner Bequest, 1856. Foto: Wikimedia Common

ISBN 978-91-7833-259-5 (TRYCK)

ISBN 978-91-7833-260-1 (PDF) 


\section{Abstract}

In the present thesis, I analyse how the idea of equality appeared in Swedish educational policy documents from 1946 to 2000. The dissertation aims to advance our understanding of equality as an educational ideal by analysing it as a politicotemporal problem. I do this by combining political thought with historiographical reflections. The material on which I draw is primarily governmental official reports (Statens offentliga utredningar) and Government bills. Utilising what I call the historico-political approach, I examine the empirical material by focusing on how the idea of equality has been envisaged with regard to the past, present, and future. The chief problem is divided into five research questions, which in turn are analysed in four separate studies.

By exploring how the relationship between teacher, pupil, and content has appeared in key policy documents, I reveal a crucial dislocation in educational policies that has been overlooked to date. Whereas the idea of centring education around the individual pupil was initially popularised in the post-war period and articulated as a more efficient means for ensuring that pupils assimilated greater knowledge, this successively morphed into a democratic goal in itself, in line with the overt attempt to further the democratisation of the educational system in the 1970s. Concurrently, the role of the teacher and the content taught also underwent substantial changes. I show how these transformations can be seen as indicative of a new way of temporally charging equality, where the present is given priority at the expense of both the past and the future. Building on and yet diverging from previous research on Sweden's educational reforms, in which the reforms around 1990 are depicted as a break from earlier educational policies, my results showcase important and seldom noted strands of continuity in educational policies from 1946 to 2000 . In short, this project shows how the desire to further equalise conditions in the educational system paradoxically undermined the democratic order that it was intended to strengthen, helping to pave the way for the changes around 1990, which are often depicted as manifestations of a major, systemic shift.

\section{Keywords}

Equality, politico-temporal problem, education, post-war period, Sweden, political thought, regime of historicity, Arendt, democratic paradox, imaginary equality, the social, Tocqueville, world 



\section{Tack/Acknowledgements}

Bland alla de personer som på olika sätt och i olika sammanhang har bidragit till att göra mitt tänkande mindre dunkelt och på så vis ge föreliggande avhandling en klarare form, vill jag framförallt lyfta fram mina tre handledare. Min huvudhandledare Johan Kärnfelt har med sin klara blick kommit med förtydligande synpunkter på form såväl som innehåll och har även stöttat och uppmuntrat när det har behövts. Tack även för hjälpen med sättningen av avhandlingen. Min biträdande handledare Cecilia Rosengren vill jag tacka för hennes skarpa kommentarer och för många givande diskussioner. Jag vill även rikta ett särskilt tack till henne för hjälpen vid mitt första Parisutbyte 2013. Min andra biträdande handledare Thomas Karlsohn har med sin lärdom och analytiska blick varit ett omistligt stöd under hela avhandlingsarbetet. Hur betydelsefull hans breda överblick över diverse olika fält har varit för denna avhandling kan inte nog betonas. Jag är oerhört tacksam för all den kunskap och språkliga känslighet som ni delat med er av!

Bland de som bidragit till att strukturera upp detta arbete utanför vår institution vill jag först och främst tacka min slutopponent Victoria Fareld. Victorias kombination av djuplodande kunskaper, analytisk stringens och inkännande läsning av manuskriptet uppmärksammade mig på flera oklarheter. Hennes kommentarer har varit ett ovärderligt stöd när jag arbetat om texten.

Ett stort tack går även till doktorandkollektivet i idéhistoria vid Göteborgs universitet. Ett särskilt tack vill jag rikta till Anton Jansson samt min rumskamrat under det första halvåret, Julia Nordblad, för er öppenhet och försök att introducera mig till den för mig nya miljön. Under hela min tid som doktorand har jag lärt mig otroligt mycket av mina kolleger - doktorander såväl som seniora forskare - på vårt doktorandseminarium. Jag är mycket tacksam för de oerhört lärorika år som jag har tagit del av denna intellektuellt dynamiska miljö. Bland alla som bidragit till detta bör - igen Johan Kärnfelt framhållas som har lett doktorandseminariet under större delen av denna tid. Ett särskilt tack vill jag även rikta till Martin Wiklund 
för läsning av hela manuset under slutspurten, samt för klargörande synpunkter och diskussioner även under resten av doktorandtiden. Tack även till Michael Azar som läste och kom med klargörande synpunkter på delar av manuskriptet i slutfasen.

Vid institutionen vill jag rikta ett varmt tack till Annika Bourdieu och Kristina Svensson samt alla andra som har hjälpt till med diverse administrativa spörsmål. Deras stöd i alla tänkbara frågor och alltid lika vänliga bemötande har uppskattats mycket. För både intensiva diskussioner och uppsluppna samtal tackar jag även Anton Svanqvist, Britas Benjamin Eriksson, Christer Ekholm, Christine Quarfood, Elin Thorsén, Jens Norrby, Johan Revelj, Lisa Schmidt, Michael Azar, Signe Leth Gammelgaard (i synnerhet för betydelsefulla synpunkter i slutet), Sandra Grehn och Therese Svensson på Bengt Lidnersgatan 7. Tack även till Sandra Kottum för meningsfulla diskussioner om diverse under åren som gått. För det mer praktiska arbetet kring utformandet av arbetet vill jag även tacka Thomas Ekholm.

Under mina utbyten i Paris har jag blivit varmt välkomnad och står i tacksamhetsskuld till flera personer. Tack till professor Sylvain Briens vid REIGENN, Sorbonne för hans hjälp och stöd i alla möjliga olika frågor. Tack även till professor Yohann Aucante för att ha bjudit in mig att presentera mitt projekt vid sitt seminarium vid EHESS. Je voudrais aussi exprimer ma grande reconnaissance au professeur François Hartog de m'avoir accueilli dans son séminaire et de ses commentaires sur mon travail. Mais je tiens surtout à exprimer ma profonde gratitude envers le professeur Frédéric Brahami pour sa très grande générosité et son appui tout au long de mon séjour à l'EHESS. Son séminaire, son soutien et les conversations que nous avons entretenus ont été indispensables dans mon travail sur cette thèse. J'ai aussi une dette de reconnaissance envers Piero Colla, qui à travers nos longues conversations sur Skype, nos rendez-vous intensifs un peu partout en Europe, et ses commentaires par écrit, a été un interlocuteur central à la fin du travail sur cette thèse. Enfin, je voudrais aussi remercier Eddy Gaillard pour nos conversations stimulantes pendant mon séjour à l'EHESS.

Utanför LIR vill jag även tacka Sharon Rider och deltagarna vid högre seminariet i språk- och kulturfilosofi vid Uppsala universitet, Joakim Landahl och deltagarna vid utbildningshistoriska seminariet vid Stockholms universitet, samt Ylva Waldemarsson och deltagarna vid seminariet på Samtidshistoriska institutet för värdefulla kommentarer. Jag vill också tacka Ulf P. Lundgren och Donald Broady för att de har tagit sig tid att diskutera diverse frågor rörande de skolpolitiska omvandlingarna i Sverige under efterkrigstiden. 
Avhandlingsarbetet, och i synnerhet mina två utbyten, har möjliggjorts genom generösa bidrag från: Anders Karitz Stiftelse, Gertrude och Ivar Philipsons stiftelse, Helge Ax:son Johnsons stiftelse, Hvitfeldska stiftelsen, Stiftelsen Stipendiefonden Viktor Rydbergs minne, Stiftelsen Karl Staffs fond för frisinnade ändamål, Stiftelsen Paul och Marie Berghaus donationsfond, Svensk-franska stiftelsen, samt Adlerbertska Stipendiestiftelsen.

Bland mina vänner är det i synnerhet tre personer som med sitt intresse och öppenhet för att diskutera politisk teori i en vid mening har varit omistliga vid arbetet med avhandlingen; tack för allt Carl, Matilde och Sebastian - våra diskussioner och era synpunkter och förslag på förändringar har på ett avgörande vis bidragit till att klarlägga vad jag här vill och kan säga. Tacksam är jag även för de mycket värdefulla kommentarer som jag i ett tidigt skeende fick från Caj Strandberg och Rune Romhed. Tack även till Jacob Jonsson och Marco Tiozzo för klargörande synpunkter. Jag vill även rikta ett varmt tack till mina andra, för denna avhandling mer eller mindre intresserade, vänner för alla de samtal och moment av samvaro som vi har haft tillsammans; ingen nämnd, ingen glömd.

Avslutningsvis vill jag tacka alla er i min familj, i synnerhet min mor och farmor för er tilltro och ert osvikliga stöd, och min far och Inger både för ert aldrig sviktande stöd och för era kommentarer på diverse textutkast under arbetets gång. En särställning inom denna trängre skara intar emellertid du Anne, min förstaläsare, för dina klargörande synpunkter och ditt tålamod. Jag tillägnar denna bok NW, via det förflutna in i framtiden.

Orust den 4 november 2018 


\section{Content}

I. Introduction 1

Initiation 1

Purpose and Outline of the Thesis 5

Background 9

$\begin{array}{ll}\text { State of Research } & 13\end{array}$

(i) History of Education 14

(ii) Studies on Professions 15

(iii) Studies on the concept of equality in educational policies $\quad 16$

$\begin{array}{ll}\text { Material and delimitations } & 18\end{array}$

$\begin{array}{ll}\text { Material } & 18\end{array}$

Delimitations in time $\quad 21$

Method 22

$\begin{array}{ll}\text { The Historico-Political Approach } & 27\end{array}$

Excursus I: Theory and Theorising 32

II. Summary of Articles

(1) "In Praise of the Present" 35

(2) "The Paradox of Democratic Equality" 37

(3) "Tocqueville, Educational Politics and Individualisation” 39

(4) "Equality and Education" 40 
III. Concluding Discussion 43

Educating for Reality 44

Presentism and the Late Modern Teacher as a Character $\quad 51$

The Social and the Role of Institutions $\quad 55$

On the possibilities and limits of the social as an analytical tool $\quad 58$

Rupture and Continuity $\quad 62$

Excursus II: The Primacy of the Political? 73

$\begin{array}{ll}\text { The Aporia of Equality } & 76\end{array}$

The Janus Face of Abstract Universality 82

Closing Remarks 86

$\begin{array}{lr}\text { Svensk sammanfattning } & 89\end{array}$

Syfte, frågeställningar och material $\quad 89$

$\begin{array}{ll}\text { Angreppssätt } & 90\end{array}$

$\begin{array}{ll}\text { Resultat } & 90\end{array}$

$\begin{array}{ll}\text { Bibliography } & 95\end{array}$

Appendix I: "In Praise of the Present"

Appendix II: "The Paradox of Democratic Equality"

Appendix III: "Tocqueville, Educational Politics and Individualisation”

Appendix IV: "Educational Equality"

Appendix V: Reports 

All fixed, fast-frozen relations, with their train of ancient and venerable prejudices and opinions, are swept away, all newformed ones become antiquated before they can ossify. All that is solid melts into air, all that is holy is profaned, and man is at last compelled to face with sober senses his real conditions of life, and his relations with his kind.

Karl Marx \& Friedrich Engels, The Communist Manifesto

If we want everything to remain as it is, everything must change.

Giuseppe Tomasi di Lampedusa, Il Gattopardo 



\section{Introduction}

\section{Initiation}

The aim of democratic upbringing must be a free, primordial, and independent personality, a personality that is not suppressed or bound by others, and that neither herself attempts to dominate others, but who freely can cooperate with other humans in love and work. ${ }^{1}$

In his reflections upon the motives behind the French Revolution, the French politician Pierre-Louis Roederer - whose participation in that event was immortalised when Jacques-Louis David included him in the drawing of The Tennis Court - writes that the primary force behind the revolution was "the passion for equality". ${ }^{2}$ Throughout the modern period, the concept of equality has played a key mobilising role in the transformation of Western societies. However, more recently a number of measures serve to indicate that the world has become more and more unequal. As Pierre Rosanvallon has argued, for around three decades now, equality has undergone a crisis, which reflects the "collapse of a whole set of old ideas of justice and injustice". ${ }^{3}$ This breakdown can be related to a range of reforms that have occurred within a number of societal domains and which often, with varying degrees of nuances, are described as manifestations of a neoliberal social order. ${ }^{4}$

Within the geographical confines of Sweden, the diminution of equality is particularly salient within the educational sphere. As the liberal-conservative Swedish politician Carl Bildt stated upon taking on his role as Prime Minister of Sweden in 1991, one of the foremost objectives of his newly

1 Einar Tegen, "Den demokratiska uppfostrans mål”, Skola och samhälle 3-4 (1945): 65.

2 "la passion de l'égalité", Pierre-Louis Roederer, L'esprit de la Révolution de 1789 (Paris, 1831), 9.

3 "l'affaissement de tout un ensemble de répresentations précédents du juste et de l'injuste”, Pierre Rosanvallon, La société des égaux (Paris: Éditions du Seuil, 2011 ), 18.

4. David Harvey, A Brief History of Neoliberalism (Oxford: Oxford University Press, 2005). 
formed government was to launch "a revolution in the individual's liberty to choose". ${ }^{5}$ This declaration of intent, which on a discursive level neatly illustrates the political ambitions of the new government, captures the proclaimed systemic shift to a "neoliberal" order with its focus on the individual at the expense of the notion of equality as a structuring ideal. ${ }^{6}$ Subsequently, already in 1992, a Government bill was passed that in the long run would transform the Swedish educational system into one of the world's most market-driven systems, based on a voucher system. ${ }^{7}$

The introduction of a voucher system in Swedish educational politics was but one of a number of structural reforms of the educational system around 1990. Alongside this we find the preceding decentralisation from the State to the municipalities of the governing of schools, and the shift from a ruleoriented governance to a form of management by objectives, to mention just two of the most significant reforms in this regard. When considered in their totality, as a single reform cycle, they are often depicted as manifestations of a system change. With these reforms, the educational system is said to have shifted from being a public good to a private good. ${ }^{8}$ Speaking with the oftenevoked public committee regarding the distribution of power in Sweden of 1985, the democratic form of Swedish society had become less societycentred and more individual-centred. ${ }^{9}$ On both sides of the political spectrum - whether welcomed or lamented - this development is read as marking a notable shift from equality towards an individual-centred freedom to choose. ${ }^{10}$ In contrast, by focusing on how the idea of equality appeared in

5 “en valfrihetsrevolution”, Carl Bildt, Declaration of Government, Riksdagens protokoll 1991/92:6. And in this, the Liberal Coalition government of 1991-1994 would prove to be successful, as in the following year they launched a bill that served to enhance the freedom to choose in school in Valfrihet $i$ skolan, bill 1992:93:230, much along the lines of the type suggested by Milton Friedman around 40 years before, see: Milton Friedman, "The Role of Government in Education", in Robert A. Solo (ed.), Economics and the Public Interest (New Brunswick, NJ: Rutgers University Press, 1955). Apart from the voucher system, the number of possible courses for pupils to choose from, and in particular for high-school pupils, underwent a virtual explosion.

6 I place "neoliberal" within quotation marks since the concept has been defined in various ways, and not all would agree that increased individual liberty forms an essential component of it.

7 Andreas Fejes \& Magnus Dahlstedt, Skolan, marknaden och framtiden (Lund: Studentlitteratur, 2018).

8 Tomas Englund, “Utbildning som 'public good' eller 'private good': Svensk skola i omvandling?”, in Tomas Englund (ed.), Utbildningspolitiskt systemskifte? (Stockholm: HLS Förlag, 1996).

$9 \quad 1985$ års maktutredning, SOU 1990:44, 390ff.

10 Francis Sejersted, Socialdemokratins tidsålder: Sverige och Norge under 1900-talet (Nora: Nya Doxa, 2005), 405ff. 


\section{INTRODUCTION}

educational policy documents throughout the post-war period, the findings of the present thesis indicate that we have good reasons to qualify our understanding of this shift.

Alongside the line of conflict around the introduction of a voucher system, which clearly ties in to a much older field of political contestation between left and right, another dividing line runs between those (from the left) who have tended to stress the importance of educating for citizenship and criticise the reforms since the 1990s, and those (tending to come from the political right) who have been much more prone to emphasise the primacy of transmitting knowledge. ${ }^{11}$ Whereas the former issue - the voucher system - is interlocked with political tendencies stretching further back in time, the latter cleavage is somewhat puzzling, not least in light of the long struggle of labour movements across the world to facilitate the inevitably "fatiguing climb" leading up to the "luminous summits" of knowledge for children also from unprivileged conditions. ${ }^{12}$

The two ideal-typical positions - with the mainly leftist articulation emphasising the role of school in preparing pupils to become active citizens, and those with a bent towards the right who stress transmission of knowledge and freedom of choice - both appear to have their origins in the attempts to democratise the educational system.

The introduction of universal suffrage in 1919 shed new light on specific questions - such as those around improving the education of children in the countryside and those from humble backgrounds in the cities - that, while not being completely ignored in the past, were only now starting to receive more serious attention. But it was in the immediate aftermath of the Second World War when the attempt to democratise the educational system became intensified.13 One of the clearest manifestations of this came in the

11 I have elsewhere shown how the dichotomy between the so-called "fuzzy" school (flumskolan) and the school for learning was articulated by the "Knowledge movement" (Kunskapsrörelsen) in the late 1970s. However, with time, it seems that the initial line of conflict shifted in the 1980s, as the movement in the second half of the 1980s, judging from their main forum, the journal Äplet, started advocating actions - such as the introduction of a voucher system - that do not follow from their initial critique, see: Tomas Wedin, "The Rise of the Knowledge School and the Resurrection of Bildung", Nordic Journal of Educational History 2.2 (2015): 49-67. For an analysis of how the trope "knowledge school" (kunskapsskolan) was appropriated from the 1990s onwards, see: Matilda Wiklund, Kunskapens fanbärare (Örebro: Örebro universitet, 2006).

12 Karl Marx, Preface to the French Edition, Capital, Volume 1 (London: Penguin Classics, 1990 [1867]), 104. Although the question, as we shall see, becomes less unambiguous when assessed in light of how the individual pupil had been envisioned in previous decades.

13 Ylva Boman, Utbildningspolitik $i$ det andra moderna: Om skolans normativa villkor (Örebro: Örebro universitet, 2002); Gunnar Richardson, Drömmen om en ny skola (Stockholm: 
decision by the Social Democratic Government at the time to appoint a committee tasked with preparing a thoroughgoing reform of the educational system, aiming to adapt it to the needs of a changing, increasingly democratic society.

In parallel with these attempts to reform the educational system, a number of political problems were brought to a head in the wake of the first wave of educational reforms between 1950 and 1970. Key among these were how to balance different competing interests and political aims within the educational system, such as preparation for the labour market by improving the meritocratic function of the educational system on the one hand, and how to prepare pupils to become participative citizens on the other hand.

From then on, the problem of equality became a crucial concern in educational politics: from the committee of 1946 and throughout the post-war period up until - if we are to believe the dominant historiography - the 1990 s, when equality successively gave way to individual liberty as a structuring ideal, as manifested by the voucher system reform of 1992.14 Simultaneously, however, key educational ideals, often associated with the period preceding the 1990s, continued to be reflected in policy documents after the purported shift as well..$^{15}$ Thus, rather than reversing the launched reform of 1992, the Social Democratic government that replaced the liberal coalition government in 1994 in many respects furthered the educational policies that they had promoted for decades. ${ }^{16}$ Indeed, in many respects, the teachers training Government bill of 1999/2000:135 could be considered the acme of crucial post-war educational ideals, stretching right back to the 1950s, with far-reaching calls to further democratise teaching practices by creating a more equal educational system. ${ }^{17}$ How are we to make sense of this?

Liber/Allmänna förlaget, 1983); Johan Östling, Nazismens sensmoral (Stockholm: Atlantis, 2008), 152.

14 This understanding ties in with the "traditional picture" that, as it is presented in a leading introductory book in political philosophy: "people on the left believe in equality, and hence endorse some form of socialism, while those on the right believe in freedom, and hence endorse some form of free-market capitalism", Will Kymlicka, Contemporary Political Philosophy (Oxford: Oxford University Press, 2002), 1-2.

15 A contradiction that the Swedish historian Hans Albin Larsson has also pointed out. See: Hans Albin Larsson, Skola eller kommunal ungdomsomsorg? Om att försöka skapa en jämlik och demokratisk skola (Stockholm: SNS Förlag, 2002), 109.

16 As exemplified by, for example, Bill 1995/96:206 and Bill 1997:98:94, both of which comprise questions regarding the attempts to integrate school and pre-school, as well as the teacher training bill 1999/2000:135. Cf. Hans-Albin Larsson, Mot bättre vetande: En svensk skolhistoria (Stockholm: SNS Förlag, 2011), $101 \mathrm{ff}$.

17 In e.g. the official report SOU 1952:33, Den första lärarhögskolan: Betänkande utgivet av 1946 års skolkommission, which served to discuss a teacher training formation fit to address the requirements of a more unitary educational system. 


\section{Purpose and Outline of the Thesis}

Out of these ostensibly contradictory impressions, my interest has shifted from the manifest marketisation of the educational system and the problem of inequality, and towards how equality has been articulated in what is often depicted as the construction of the democratic and equality-promoting school from 1946 until the 2000s. More specifically, the aim of the present thesis is to examine how the problem of equality - particularly in terms of how the individual has been imagined in relation to the collective - appeared within key educational policy documents between 1946 and 2000 in Sweden. ${ }^{18}$

The problem will be assessed via what I will refer to as the historicopolitical approach. This designates a way of tackling societal issues with regard to both the latent and manifest ways in which they are temporally charged, that is, how they betoken different ways of orienting oneself towards the past, present, and future. ${ }^{19}$ From the encompassing historicopolitical approach, it follows that the underlying issues - namely the relationship between individual and collective, equality and the closely related ideal of freedom - are analysed as politico-temporal problems. Although this way of tackling political problems could be applied to almost any politically relevant question, I maintain that it is an especially apt method through which to examine the idea of equality in the educational system, in virtue of being an institution that conducts a kind of intergenerational mediation. Alongside the aforementioned manifestly structuring questions, regarding how to balance the formation of democratic citizens vis-à-vis the needs of the labour market, this is a crucial and often overlooked dimension within studies of educational history.

With regard to the French historian François Hartog's concept of regimes of historicity, to which the present approach is heavily indebted, the historico-political approach is located at the intersection of political theory

18 By policy documents, I refer to "plans, programs, principles or more broadly the course of action of some kind of actor, usually a political one such as a government, a party, or a politician”, see: Tony Bennett, Lawrence Grossberg, \& Meaghan Morris, New Keywords: A Revised Vocabulary of Culture and Society (London: Blackwell Publishing Ltd., 2005), 258. Under the heading "Material", I will further qualify the epistemic status of the material on which I draw.

19 In some relevant respects, this ties in with what the Swedish sociologist Håkan Thörn in his thesis, drawing on Bakhtin's idea of the chronotope, refers to as the spatio-temporal structures of political texts, see: Håkan Thörn, Modernitet, sociologi och sociala rörelser (Göteborg: Sociologiska institutionen Göteborgs universitet, 1997), 185ff. A similar approach is also present in Peter Osborne's idea of time politics, which he defines as "politics which takes the temporal structures of social practices as the specific objects of its transformative (or preservative) intent". See: Peter Osborne, The Politics of Time: Modernity and Avant-Garde (London: Verso, 1995), xii. 
and historiography. ${ }^{20}$ Under the headline Method, I will further elaborate on what is meant by this approach, and what analytical affordances it provides in comparison with more empirically driven studies, as well as pointing out the limits entailed by the pursued approach. In "Excursus I: On Theory and Theorising", I offer a brief outline of how my approach relates to strictly perspectivist-driven studies, where theories predetermine the object of the analysis.

It follows from the purpose - namely to examine how the idea of equality has appeared in policy documents - that the ways in which these ideas have been implemented will not be analysed. As indicated, my aim is to emphasise how the articulated ideas can be read as artefacts through which, when analysed diachronically, we can also discern societal changes. In light of the exceptional position of the school, beside the family and immediate surrounddings, as a central transmitter of values and ideals in modern society, it is a particularly suitable object with which to analyse the idea of equality, and how, via the individual-collective axis, it has been envisioned during a given period of time. To this end, the separate studies that comprise this thesis serve to elucidate how the idea of equality, as a politico-temporal problem, has been expressed in Sweden via the country's educational policy documents.

The purpose set out above falls into four separate studies, each of which address various aspects of the structuring problem through five research questions (the last article answers two questions). In the first two studies of the thesis - (1) "In Praise of the Present: The Pupil at Centre in Swedish Educational Politics in the Post-War Period" and (2) "The Paradox of Democratic Equality: On the Modified Teacher Role in Post-War Sweden" - I empirically examine how the individual pupil was envisioned in relation to both the teacher and the content taught in educational policies during that period of time. In the first article, I answer the question of how the ideal to place the pupil at the centre of education changed during the period of 19351992 in relevant educational policy documents. In the second article, the main question is how the ideal of a good teacher was modified throughout the period, as well as how this relates to changing views of the content of the knowledge taught throughout the period 1946-2000.

Drawing on the results of these more empirically oriented articles, the third article - (3) "Tocqueville, Equality, and Individualisation: On the Democratisation of Pre-University Education in Post-War Sweden" - serves to further the theoretical problems evinced in the two preceding articles. Here, I tackle the question of how Tocqueville's idea of modernity, as concomitant

20 François Hartog, Régimes d'historicité: Présentisme et expérience du temps (Paris: Seuil, 2012). 


\section{INTRODUCTION}

with an emerging imaginary equality, could serve to enhance our understanding of the policy changes analysed in the previous two studies.

In the fourth article - (4) "Educational Equality: A Politico-Temporal Approach" - I first establish how the presentist tendencies and the imaginary form of equality from the third article should be understood as entwined problems. As such, it serves to elaborate on the analytical concepts emerging out of the first three studies. In the second part of the article, I answer the fifth question of the thesis: How can Hannah Arendt's reflections on the relation between education and politics be mobilised to constructively address the discerned politico-temporal aporia of equality? Therefore, rather than expanding my empirical results horizontally with two more studies, I have opted for what I refer to as a vertical analysis of the questions. The idea of verticality alludes to two aspects: the central role of theorising within the thesis, and the diachronic approach. ${ }^{21}$

The reason for adopting such an approach is that I have wanted to consider the material with as few theoretical presuppositions as possible, attempting to pursue a more internal or immanent critique of the concept of equality with the empirical studies serving as a basis for the ensuing theoretical discussions. Put differently, I want the analytical constructs to interact with the empirical material, rather than the former being imposed on the latter. As such, the concepts around which the theoretical qualifications revolve in the last two articles all stem from the empirical analyses.

The study contains historical claims, albeit necessarily conditioned by the limited empirical basis, and serves to pursue an internal critique (via the outlined historico-political approach) of the alleged attempts to democratise the educational system. By internal, I mean to say that the analysed politicotemporal problems, as well as the more constructive approach in the fourth article, are extracted from the manifest attempts to create a school in the service of democracy as a political project. ${ }^{22}$ This should be contrasted to, for example, a critique directed against the reforms with reference to some external, competing aim of the educational system, such as improving its capacity to enhance Sweden's competitiveness, for example. ${ }^{23}$

21 I elaborate on what I mean by this approach under "Method".

22 "Internal critique" is a definition that I have borrowed from Raymond Geuss. In The Idea of a Critical Theory, he argues that an essential characteristic of Ideologiekritik is that it proceeds not from external or transcendent yardsticks, but rather from "views of the good life, from the notions of freedom, truth and rationality" that the subjects analysed themselves subscribe to. See: Raymond Geuss, The Idea of a Critical Theory (Cambridge: Cambridge University Press, 1981), 87f.

23 Another possible and equally interesting external perspective relates to the temporal horizon that I intentionally have chosen to leave out, to wit, eternity. Arendt has made an analytically very useful distinction in this regard. In e.g. The Human Condition she 
In the concluding section, Chapter III, the analysis is extended. The chapter falls into three parts. In the first, under the heading "Educating for Reality", I mainly summarise and elaborate on the results of the first three articles. In the second part, "Rupture and Continuity: The Transmutations of Equality", I contrast my findings with previous analyses of the problem at hand. In the third part, "The Aporia of Equality", the constructive position delineated in the fourth study, in particular its political-theoretical underpinnings, are expounded on via related debates around the ideal of political equality. In line with how I emphasise the importance of the historicopolitical approach with regard to previous studies in educational history, I also stress the uniqueness and pertinence of the outlined approach with respect to competing political-theoretical approaches to the complex of problems. Thus, whereas my findings in the first two parts are contrasted with competing perspectives on the educational reforms, the third serves to plot my results within a larger framework and situate my findings in relation to associated political-theoretical issues. The thesis is then brought to an end under the heading "Closing Remarks".

The concluding discussion should be read not merely as a summary of my results, but as a substantial development of them. In order to follow the argumentation, it is thus recommended that having read the current introductory section, the reader moves on to the four articles, and finishes by consulting the concluding section. In addition, in terms of the compiled nature of the thesis, some degree of repetition is inevitable, as the central themes appear in both the articles and the conclusion.

The thesis also contains two excurses: one (in the first section) in which I develop the meaning ascribed to theorisation; and a second (in the third section) in which I suggest how my results might be further enhanced by way of contrasting them with another theoretical tradition.

distinguishes between eternity, relating to bios theoretikos, whether philosophical or in the form of the religious traditions, and immortality, which relates to bios politikos and life in the polis. And since what is at stake in this thesis relates to political life, aiming at creating an educational system in the service of democracy, and not for the salubrity of an eternal soul, I have chosen to leave the temporal dimension of eternity out of the analysis. This is not because Arendt is necessarily right-indeed, it could be argued that it is precisely the loss of eternity and some form of guiding Order that has led educational politics astray; rather, it is because I will pursue an internal critique, maintaining the immanent yardsticks against which the educational reforms were made. Hannah Arendt, The Human Condition (Chicago: University of Chicago Press, 1998), 17ff. For a comparison of the approach pursued here with two competing strategies, see: Tomas Wedin, "Countering the Paradoxes of Equality: Three Politico-Temporal Approaches", unpublished article. 


\section{INTRODUCTION}

With the aim of introducing the central problematics of the dissertation, we will now briefly consider the historical background out of which the more specific problems of the thesis emerged.

\section{Background}

A milestone in the chain of reforms that sought to transform the Swedish educational system during the post-war period was the decision in 1962 to create a nationally integrated school - a comprehensive school. In the ensuing 10 years, this new school would replace the myriad of different educational paths that had existed previously in what is referred to as the parallel school system (not least with regard to how children from different social classes tended to attend different schools). Subsequently, the 9-year comprehensive school, which had been discussed and planned intensively since the appointment of The School Commission of 1946, gradually replaced the earlier system. ${ }^{24}$ There was strong political support for the reform, in both the Swedish Parliament and most sites to which the proposal was sent out before being implemented..$^{25}$

Although the comprehensive school marked an important victory for those who had advocated a less segregated educational system, it did not imply that all problems would be solved once the parallel school system had been replaced. The differences between pupils who had until then been dealt with through parallel educational paths had now become a challenge that would have to be worked through within the confines of the comprehensive school. The question of differentiation was one of the fiercest bones of contention. ${ }^{26}$ Other problems that emerged in the wake of the comprehensive school included the predictable teacher shortage, as well as the question of how the different levels within the new school would be woven together; in particular, the relationship between intermediate and senior level teachers was a matter of debate. ${ }^{27}$ Nevertheless, in 1972, the reform was enacted throughout the country.

24 But which in varying forms had been promoted by educational politicians such as Adolf Hedin, Sven Adolf Hedlund, and, most famously, Fridtjuv Berg. For an analysis of the visions and political work of the latter, see: Joakim Landahl, Politik \&ं pedagogik: En biografi över Fridtjuv Berg (Stockholm: Lärarstiftelsen, 2016).

25 However, although all parties agreed when the decision was finally taken, major cleavages existed between the different parties regarding the design of the comprehensive school (and before that, opinions differed as to how, more precisely, the results of the pilot schools launched in the 1950s should be evaluated), see: Richardson 1983, 213ff; Boman 2002, 252ff.

26 Richardson 1983, $201 \mathrm{ff}$.

27 As the pedagogical researcher Erik Wallin has shown, this was a relevant background to the nowadays fiercely criticised educational technology that emerged during the 
In the time between Parliament's decision and the reform's implementation, it was also decided that a reformed upper secondary school - to meet the adapted needs of the new comprehensive school - would replace the earlier one. As a consequence, new curricula were developed for both the comprehensive school and the upper secondary school. The situation is neatly captured by the commissioners behind the official report The individual and school (Individen och skolan) from 1975, who concluded that:

[...] the thorough work of the external school reforms is now finished for the foreseeable future. For the educational system, the task ahead of us is to now find better ways through which all children and teenagers can experience schoolwork as stimulating and the teaching as meaningful. ${ }^{28}$

The quote encapsulates what could be considered to be the broad outlines of a second phase in the remoulding of the Swedish school from the 1970s and onwards. Then, around 1990, a number of reforms were launched, three of which are of particular relevance for this thesis, and which had a profound effect on the Swedish school. These were, firstly, the municipalisation of school and the concomitant replacement of the National Board of Education (Skolöverstyrelsen) with the National Agency for Education (Skolverket). The second crucial reform was the abandonment of the vicinity principle, which was replaced by a voucher system in 1992, alongside far more generous rules and regulations for establishing private schools and a veritable explosion of opportunities to choose between different courses. The third central change was the replacement of the rule-governed system with a goal-oriented system along with the introduction of the National Agency of Education, as noted previously.

Following the launch of this cluster of reforms, a number of new questions emerged, emanating from new political and technical experiences. An example can be seen in the questions relating to the rapidly expanding development of information technologies since the 1990s, and the problems and opportunities that followed in their wake. ${ }^{29} \mathrm{~A}$ distinguishable but closely related question concerns what new capacities would be required of both teachers and pupils as a consequence of the accelerating technological changes,

1960s. See: Erik Wallin, "Svensk utbildningsteknologi - dess uppgång och nedgång åren 1960-1980", Studies in Educational Policy and Educational Philosophy, E-tidskrift 2006:1.

28 " $[\ldots]$ det genomgripande yttre reformarbetet av ungdomsskolan nu är avslutat för den framtid som idag kan överblickas. För skolväsendets del gäller det att nu att söka ännu bättre vägar för att få alla barn och ungdomar att uppleva skolarbetet stimulerande och undervisningen meningsfull”, SOU 1975:9, Individen och skolan, 11.

29 For a comprehensive analysis of the rhetoric regarding these questions, see: Thomas Karlsohn, Teknik - Retorik - Kritik: Om IT-bubblan och datoriseringen av den svenska skolan (Stockholm: Carlsson, 2009). 


\section{INTRODUCTION}

or, in other words, what type of capacities would be demanded by the "new economy". Another question concerns establishing the particular "we" that should (not) be discursively constituted and addressed by the educational system. Indeed, as we will see, a prominent strand in educational policy documents since the late 1960 s is precisely that they manifest an increased unwillingness to articulate any collective identities whatsoever - be it in the name of class equality, antiracism, equality between the sexes, or with reference to the educational system as a tool for enhancing the pupil's competitiveness. In this regard, a tension is often assumed to exist between the territorial state on the one hand, and different forms of more recent supranational constructs such as the European Union, United Nations, as well as other forms of regional and global alliances and agreements on the other. In light of this often-evoked dimension of the changes, the present study should be considered as a contribution to what a temporally oriented approach can add to the much-analysed effects of the spatial transformations on the educational system.

With regard to the three aforementioned reforms - namely the municipalisation, the introduction of the voucher system, and management by objectives - the 1990s is often deemed to mark a break with the educational policies that came before. The period is designated as a rightward shift on the political scale with an increased focus on the individual at the expense of the collective: from the state as representing a collective order to the individual pupil. ${ }^{30}$ One expression of this that is often invoked is the 1985 official report on the distribution of power in Sweden, headed by political scientist Olof Petersson, wherein the authors argue that Swedish society at the time was currently undergoing substantial changes. As an example of such transformations, the commissioners noted how citizens' demands "become increasingly differentiated", and how the public sector appeared

so Johanna Ringarp, "Utbildningspolitiken - från kommunaliseringen till PISA", in Anders Ivarsson Westerberg, Ylva Waldemarsson, \& Kjell Österberg (eds.), Det långa 1900talet: När Sverige forrändrades (Finland: Boréa, 2014), 143; Tomas Englund (ed.), Utbildningspolitiskt systemskifte? (Stockholm: HLS, 1996); Tomas Englund, Läroplanens och skolkunskapens politiska dimension (Göteborg: Daidalos, 2005); Tomas Englund \& Ann Quennerstedt (eds.), Vadå likvärdighet (Daidalos: Göteborg, 2008); Anders Fredriksson, Marknaden och lärarna: Hur organiseringen av skolan påverkar lärares offentliga tjänstemannaskap (Göteborg: Göteborg Studies in Politics, 2010); Boman 2002; Mattias Börjesson, Från likvärdighet till marknad: En studie av offentligt och privat inflytande över skolans styrning $i$ svensk utbildningspolitik 1969-1999 (Örebro: Örebro universitet, 2016); Anders Björklund, Melissa A. Clark, Per-Anders Edin, Peter Fredriksson, \& Alan B. Krueger (eds.), The Market Comes to Education in Sweden: An Evaluation of Sweden's Surprising School Reforms (New York: Russell Sage Foundation, 2005). 
less like a "solution but rather the problem". ${ }^{31}$ As a result of this shift, the commissioners argue that "the integrity of the individual ought to be more strongly emphasised", and that a vast array of power asymmetries have "a different ground than the uneven distribution of resources". ${ }^{32}$ Taken together, the commissioners claim, this has contributed to an ideological shift of emphasis from a collectivistic ideal of democracy, characteristic of the "Swedish model", towards an increasingly individual-centred ideal of democracy. .3

Notwithstanding the relevance of the undeniable changes noted by the commissioners in the passages cited above, as well as the concomitant criticism of the purported inefficiency of the public sector that intensified during the 1980s, it is possible to discern particular political tensions, which indicate that the roots of this critique lay deeper in the ideological ground. One such inherent structural problem is the tensions engendered by a society that strives to, in the words of Marx and Engels, relentlessly set itself anew, i.e. the temporal acceleration with which it appears to be associated. If the incessant creative destruction of the dynamic generated by the capitalist system entails that "all that is solid melts into air", and that, as a consequence, all "fixed relations [...] are swept away" and "all new-formed ones become antiquated before they can ossify", what are the implications of this for our conditions as political beings? ? $^{34}$ What are the politico-temporal effects of the modern impulse to have men facing their "real conditions of life" with "sober senses"? ${ }^{35}$ Put otherwise, how are we to envision democracy as a promise of freedom - privately and politically - in societies constituted out of the past as a negative counter-image? And what have been the impacts of these structural changes on the educational system? In what ways

31 "blir alltmer differentierade"; "lösningen utan som problemet”. SOU 1990:44, Demokrati och makt $i$ Sverige: maktutredningens huvudrapport, 392.

32 "den enskildes integritet bör betonas starkare [...] annan grund än resursers ojämna fördelning”, SOU 1990:44, 392; 394.

33 SOU 1990:44, s. 14f; 402ff.

34. In the original German, the formulation is a clear allusion to the emerging industrial landscape: "Alles Ständische und Stehende verdampft" (my italics), and the literal translation is thus not "melts into air", but rather vaporises, or evaporates. With regard to the present thesis, this double meaning of the original German has the advantage of simultaneously accentuating how their text both took form against another backdrop and is something in which we can recognise our own society. See: Karl Marx \& Friedrich Engels, "Manifest der Kommunistischen Partei" (last version from 1890), in MarxEngels Werke, Band 4 (Berlin: Dietz Verlag, 1977), 465. For an intriguing analysis of the "Manifest" read as a modernist work, see: Marshall Berman, All That is Solid Melts into Air (London: Verso, 1983).

35 Karl Marx \& Friedrich Engels, The Communist Manifesto (Oxford: Oxford University Press, 2008), 6. 
has temporal acceleration been reflected in certain visions of education following the end of the Second World War? It is such questions that have served to inspire and provoke the work presented in this thesis.

With the democratisation of society and the expansion of the welfare state via Keynesian economic policies throughout the post-war period, the institutionalisation of these ideals entered a new phase; new in the sense that now, on a broad scale, the distributive ideals that had primarily been circumscribed to political ideals to be realised, were now successively implemented in political practice. In the present thesis, I will analyse what seems to have been the underlying ideas that gave form to the post-war educational reforms in light of the broader problems that have structured political life in the modern period. In other words, how might we understand the various justifications of the democratisation of the educational system as attempts to respond to the wider questions set out in the previous paragraph?

\section{State of Research}

There is a wide array of research horizons in relation to which this thesis has taken shape. Apart from the empirical problems on which I draw, there are, as we shall see, some theoretical fields of research to which I wish to contribute.

In the ensuing discussion of the state of research, I will focus on and present what I take to be the three most pertinent and clearly identifiable fields of research. In spite of the theoretical questions addressed, there is a clear bias for more empirically oriented fields of research. I have chosen to structure the study in this way so as to emphasise the primary object of the thesis, i.e. to enhance our understanding of equality in educational policies throughout the post-war period. As such, it accentuates the instrumental role of theory within the thesis, serving to shed light on the empirical transformations. By implication, there are a number of fields of research on which I will trespass, such as the exegesis of Arendt's political thought, for example. However, with regard to the principal aim of the thesis, these remain secondary. Furthermore, there are some individual studies that clearly touch on closely related themes, but do not fit within the fields of research mentioned. For these studies, while I will refer to them when necessary in the concluding section, they will not be presented here. ${ }^{36}$

36 I have in mind in particular the seminal study Är svensken en människa by Henrik Berggren and Lars Trädgårdh, which in addressing individualism in Sweden by drawing on, among others, Tocqueville, touches on themes that are central to this dissertation. See: Henrik Berggren \& Lars Trädgårdh, Är svensken en människa (Stockholm: Norstedts, 2014). Another study falling within the category of non-categorisable previous studies is Helena Stensöta's study on the expansion of caring norms within the educational sy- 


\section{(i) History of Education}

The primary field of research for this thesis is that of post-war educational history. Within this field, the dominant narrative holds that the Swedish educational system underwent an intensified process of democratisation throughout the post-war period, with the curriculum of 1980 marking its peak. Subsequently, in the second half of the 1980s, this was successively replaced by what could be called a neoliberalisation of educational politics, indicating a systemic political shift. Along the lines of Tomas Englund's argumentation, as exhibited in, for example, the anthology Utbildningspolitiskt systemskifte?, similar ideas have been championed in a number of studies. ${ }^{37}$

When, in the concluding section of the thesis, I return to the narrative of a systemic shift, it will be primarily by way of a dialogue with one of the more recent studies in this tradition, namely Mattias Börjesson. Notwithstanding the substantial differences between Börjesson's Neo-Marxistinspired approach and the more common sources of inspiration in a great number of other studies in this area, such as those by John Dewey and Jürgen Habermas, as well as poststructuralist and postcolonial thought, Börjesson's general narrative structure - from equality to market - coincides with the narrative structure of many other studies of Swedish educational history during this period. In line with previous research - such as the historian Johanna Ringarp's analysis of the transfer of responsibility from the state to municipalities, as well as the work of the political scientist Maria Jarl Börjesson argues that the municipalisation was decisive for the ensuing reforms, particularly in terms of the introduction of the voucher system and the deregulation of private schools, or "free" schools as they are usually called. ${ }^{38}$ However, regarding the more general wave of reforms, the system change, Börjesson's study also has the advantage of illuminating the shifting

stem and the police in Sweden in the post-war period. See: Helena Stensöta, Den empatiska staten (Göteborg: Göteborgs universitet, 2004). Besides these two studies, there a few other studies including the historian Hans Albin Larsson's book Skola eller kommunal ungdomsomsorg?, which is something of a hybrid between a polemic and a piece of research. I have therefore decided not to consider it part of the state of research. See: Larsson 2002.

37 Examples of studies in this tradition are: Ninni Wahlgren, Om det förändrade ansvaret för skolan (Örebro: Örebro universitet, 2002); Englund 1996; Åke Isling, Kampen för och emot en demokratisk skola (Stockholm: Sober Förlag, 1980); Sara Carlbaum, Blir du lönsam lille vän (Umeå: Umeå universitet, 2012); Börjesson 2016; Englund 2005; Boman 2002.

38 Börjesson 2016; Johanna Ringarp, Professionens problematik: Lärarkårens kommunalisering och välfärdsstatens förvandling (Stockholm: Makadam, 2011); Maria Jarl, Skolan och det kommunala huvudmannaskapet (Malmö: Gleerups, 2012). 


\section{INTRODUCTION}

ideological sands - the fact that school increasingly became articulated as a private good as opposed to its previous purpose as a public good. ${ }^{99}$

Studies focusing on the rupture around 1990 have made important contributions to our understanding of the educational policy changes throughout the post-war period. However, without wanting to deny the explanatory value of the conceptual couple of private good/public good, I contend that these analytical constructs appear in a somewhat different light than Börjesson and Englund seem to imply when we take into account the temporal dimension. Thus, by tackling the reforms through what I have referred to as a vertical approach, we have good reason to re-imagine equality as a political force in educational policy documents throughout the period. ${ }^{40}$

\section{(ii) Studies on Professions}

Another field of research that is pertinent to the present study, and which I discuss in particular in the second study, relates to how the teaching profession developed throughout the post-war period. The sociologist Sofia Persson has produced a lengthy historical perspective on these changes. She analyses the emergence and development of the teaching profession in Sweden from 1800 to 2000. Regarding the post-war period, she particularly emphasises the continuing disagreement between teachers from the old secondary grammar schools and teachers from the elementary school; in particular, Persson shows how their organisation in different unions had the effect of maintaining a gap between the groups. In terms of the reforms around 1990, she observes how the diverging interpretations of whether or not these reforms strengthened the teaching profession seem to hinge on whether we focus on the teaching profession as a collective or on the possibilities of the individual teacher to control her situation. Individually, she argues, teachers were accorded a greater influence in the form of more influence over content and methods. As a collective, however, teacher

9 Börjesson 2016, 209f.

40 Another study that, in relevant respects, can be subsumed under this category, and which shares some similarities with the theoretical underpinnings of this thesis, is the pedagogical researcher Daniel Sundberg's dissertation Skolreformernas dilemman: En läroplansteoretisk studie av kampen om tid $i$ den svenska obligatoriska skolan. The author here examines curricula reforms with regard to the governing and organisation of time in compulsory school. Of particular importance in his thesis is the ways in which the temporal order of the school changes in late modern society. However, in focusing on the operational side of the educational system, by conducting case studies on how the reforms launched around 1990 were implemented in schools, the problems addressed diverge substantially from the aim of this thesis, see: Daniel Sundberg, Skolreformernas dilemman: En läroplansteoretisk studie av kampen om tid $i$ den svenska obligatoriska skolan (Växjö: Växjö universitet, 2005). 
professionalism was circumscribed due to an increased influence of pupils/ parents, as well as the direct influence of the local employer. ${ }^{41}$

From a much narrower historical perspective, with a specific focus on the reforms around 1990, the historian Niklas Stenlås and economic historian Ylva Hasselberg have highlighted what they see as a process of de-professionalisation, particularly as a result of the post-1990 reforms. ${ }^{42}$ The educational sociologists Emil Bertilsson, Donald Broady, and Mikael Börjesson have argued in a similar vein. ${ }^{43}$ My contribution to this field is primarily that of accentuating how the shifts discerned within this field might be understood from a wider historico-political perspective.

\section{(iii) Studies on the concept of equality in educational policies}

Another approach to educational politics throughout the post-war period was initiated in the early 1990s by political scientists Karin Hadenius and Göran Bergström. ${ }^{44}$ In their respective theses, they tackle educational debates by applying the various conceptions of equality that had been developed within the analytical-philosophical tradition in the wake of two influential articles entitled "What is Equality?" (parts one and two) by Ronald Dworkin in $1981 . .^{45}$ But whereas Bergström more narrowly analyses the shifts

${ }_{41}$ Sofia Persson, Läraryrkets uppkomst och förändring: En sociologisk studie av lärares villkor, organisering och yrkesprojekt inom den grundläggande utbildningen ca 1800-2000 (Göteborg: Department of Sociology, University of Gotheburg, 2008), 407.

42 Ylva Hasselberg, Vem vill leva $i$ kunskapssamhället? Essäer om universitetet och samtiden (Hedemora: Gidlunds, 2009); Niklas Stenlås, "En kår i kläm - läraryrket mellan professionella ideal och statliga reformideologier", Rapport till expertgruppen for studier $i$ offentlig ekonomi 2009:6; Niklas Stenlås, "Läraryrket mellan autonomi och statliga reformideologi”, Arbetsmarknad \&̊ Arbetsliv 17.4 (2011): 11-27; Jan-Erik Gustavsson, Sverker Sörlin, \& Jonas Vlachos, Policyidéer för svensk skola (SNS Förlag: Stockholm, 2016); Shirin Albäck Öberg, Thomas Bull, Ylva Hasselberg, \& Niklas Stenlås, "Professions Under Siege”, Statsvetenskaplig tidskrift 188.1 (2016): 93-126; see also: Ringarp 2011.

43 Donald Broady, Mikael Börjesson, \& Emil Bertilsson, "Temaintroduktion: Lärarutbildningens hierarkier", Praktiske Grunde 4 (2009): 7-18; Emil Bertilsson, Skollärare: rekrytering till utbildning och yrke 1977-2009 (Uppsala: ILU, Uppsala universitet, 2014); Mikael Börjesson \& Donald Broady, Det svenska högskolefältet och lärarutbildningarna (Uppsala: ILU, Uppsala, 2006).

44 Göran Bergström, Jämlikhet och kunskap: debatter om reformstrategier $i$ socialdemokratisk skolpolitik 1975-1990 (Stockholm: Symposium Graduale, 1993); Karin Hadenius, Jämlikhet och frihet: politiska mål för den svenska grundskolan (Stockholm: Almqvist \& Wiksell, 1990).

45 Ronald Dworkin, "What is Equality? Part 1: Equality of Welfare", Philosophy \& Public Affairs 10.3 (1981): 185-246; Ronald Dworkin, "What is Equality? Part 2: Equality of Resources", Philosophy \& Public Affairs 10.4 (1981): 238-345. However, from a slightly more overarching perspective, his papers must, of course, be seen in light of the immense activities that John Rawls's seminal work $A$ Theory of Justice instigated following 
within the Social Democratic movement, Hadenius examines the educational changes throughout the post-war period from a national perspective. ${ }^{46}$ With a similar focus on the various conceptions of equality drawing on the debates mentioned, the influential curriculum theoretician Ulf P. Lundgren, who also served as Director-General for the Swedish National Agency for Education between 1991 and 1999, and the political scientist Bo Lindensjö tackle the educational reforms from 1940 to $2000 .{ }^{47}$

With some minor variations, these analyses strive to foreground how the transmutations of educational policies in the post-war period interlock with different regimes of envisioning distributive equality. Thus, the launching of the comprehensive school is seen to express the replacement of simple equality with the principle of equal opportunities, whereas the influential official report on the working environment in schools, produced by the commission on the "inner life of school" (Utredningen om skolans inre arbete), is interpreted as an expression of a more compensatory ideal of equality, "to each according her needs... from each according to her forces". ${ }^{48}$

Studies along these lines have made important contributions to our understanding of how different regimes of equality - simple equality, equal opportunities, etc. - have shaped educational policies in various periods. As a consequence, they have enhanced our understanding of the changes of the educational system more generally. However, due to the individualist bias stemming from their very distributive point of departure - equality as a constitutively distributive concept - they obscure other aspects of how we can envision equality, including the politico-temporal aspects of equality

its publication in 1971. Cf.: Andrew Williams \& Matthew Clayton (eds.), Social Justice (Oxford: Blackwell, 2004); Andrew Williams \& Matthew Clayton (eds.), The Ideal of Equality (Basingstoke: Palgrave Macmillan, 2002); Gerald Allan Cohen, If You're an Egalitarian, How Come You're So Rich? (Cambridge, MA: Harvard University Press, 2001); John Rawls, Justice as Fairness; A Restatement (Cambridge, MA: Belknap Press, 2002); Michael Walzer, Spheres of Justice (New York: Basic Books, 1983); Roger Crisp, "Equality, Priority, and Compassion,” Ethics 113.4 (2003): 745-763; Debra Satz, "Equality, Adequacy and Education", Ethics 117.4 (2007): 623-648; Elisabeth Anderson, "Fair Opportunity in Education: A Democratic Equality Approach", Ethics 117.4 (2007): 595622; Harry Brighouse \& Adam Swifts, "Equality, Priority and Positional Goods", Ethics, 116.3 (2006): 471-497; Ingmar Persson, "Equality, Priority and Person-Affecting Value", Ethical Theory and Moral Practice 4.1 (2001): 23-39; Samuel Scheffler, "What is Egalitarianism?", Philosophy \& Public Affairs 31.1 (2003): 5-39.

Cf. Boman 2002, 263ff.

${ }_{47}$ Other examples of this are: Bo Lindensjö \& Ulf P. Lundgren, Utbildningsreformer och politisk styrning (Stockholm: Liber, 2014); Boman 2002.

48 SOU 1974:53, Skolans arbetsmiljö. "A chacun suivant ses besoins... De chacun suivant ses forces”, Étienne Cabet, Voyage en Icarie (Paris, 1846), title page. With Marx’s rephrasing in The Critique of the Gotha Program, the principle spread worldwide. 
highlighted in the present work. In the conclusion, I will explain how my findings relate to these analyses of different regimes of equality.

\section{Material and delimitations}

\section{Material}

The empirical material on which the thesis is based is comprised of official publications (offentligt tryck) in the form of official reports (Statens offentliga utredningar [SOU $]$ ) and, to a lesser extent, Government bills. ${ }^{49}$ The official reports are preparatory works commissioned by the government to provide the Parliament with a satisfactory basis before taking decisions within different fields. The role of the reports is hence to elucidate various aspects of the question at hand, to analyse the problems highlighted in the directives, and often, but not always, provide the government with suggestions for possible improvements. ${ }^{50}$ A key idea behind the reports is to minimise the risk of retroactive criticism. ${ }^{51}$ It is therefore vitally important to clearly separate the reports from the decisions actually taken.

A potential complication in using reports as an empirical basis is that they are not homogenous; they may take on a number of different shapes. There are four forms in which an official report can be undertaken: it can be the work of a group of politicians (often Members of Parliament), a group of specialists within the given field, or a combination of the two. In addition to these three variations of co-authorship, there are also individual reports, which have become recurrent since the turn of the millennium. ${ }^{52}$ For the purposes of this study, where I utilise the reports as artefacts from which I attempt to detect political impulses, it seems preferable, at least as a general rule, to use collective reports, given that the authors will generally have been required to weigh up their different positions against one another. As

49 The argumentation is also, in one of the articles as well as in the conclusion, substantiated by references to relevant curricula.

50 Ulf Olsson, Folkhälsa som pedagogiskt projekt: Bilden av hälsoupplysning $i$ statens offentliga utredningar (Uppsala: Uppsala universitet, 1997), 46.

51 Jan Johanson, Det statliga kommittéväsendet: Kunskap-kontroll-konsensus (Stockholm: Statsvetenskapliga institutionen Stockholms universitet, 1992).

52 A clear pointer of this state of affairs is that a number of the central reports behind the last cycle of reforms under the liberal coalition government were single-author investigations. See e.g.: SOU 2008:27, Framtidsvägen - en reformerad gymnasieskola, led by the administration manager Anita Ferm; SOU 2008:109, En hållbar lärarutbilning, led by the professor in pedagogics Sigbrit Franke; and, more recently, SOU 2014:5, Staten fär inte abdikera - om kommunialiseringen av den svenska skolan, led by the professor in political science Leif Lewin. 
co-authored, it is easier and more justifiable to understand such reports as expressing a degree of consensus within the commission. ${ }^{53}$ As a consequence, all the reports on which I draw are the fruits of collective work.

Moreover, with the possible exception of the commission of 1985 (which, in comparison to the other reports, appears to have fewer dignitaries on its board), all reports have been written by key actors in the post-war Swedish political landscape. This is another circumstance that underpins the arguments above in support of using reports - and these reports in particular to address the research questions. In Appendix V, I supply a brief presentation of the commissionaires behind the reports, as well as how they relate to the Government bills that also serve as primary material.

In light of the fact that the official reports are commissioned by the government, and, as such, we can presume that the committee members have been carefully selected, I maintain that it is plausible to read them as crucial indications of the notions and presumptions, or the ideological undercurrents, that structure political life under a given period. All the more so when the persons behind the reports also occupy central positions within the governing bodies of the educational system. In virtue of identifying problems as well as tackling them in this way rather than another, one can analyse the reports as manifestations of political impulses during a particular passage of time. The reports are especially valuable insofar as we can analyse them to uncover what was considered possible at the time, and to reveal why one action was deemed preferable to another.

I will also draw on Government bills. I will do this in order to further bolster my argumentation by demonstrating that the discerned ideas resonate here too. Essentially, my reason for utilising Government bills is the same as that stated above in relation to official reports, albeit with the crucial difference that the Government bills can be understood as being even more politically constrained or directed than the reports. In Government bills, we also find reflections of the government behind the bill in terms of how they conceive of it in relation to antecedent political developments, which provide further clues to our interpretations of them.

Regarding the differences between these two different forms of policy documents, the Finnish educational sociologist Hannu Simola has distinguished between what he refers to as authoritative texts and directly steering documents. The former serves to affect the object of inquiry in a given direction and manifest a neutral position between the various wills of the politicians and/or individuals with specific special knowledge constituting

${ }_{53}$ This does not rule out the possibility of individual committee members voicing their concerns. However, since I read them as prisms serving to convey general tendencies, any such individual deviations will not be highlighted in the current study. 
the commission. The Government bills, on the other hand, are steering documents designed to be directly transformed into laws. ${ }^{54}$

As indicated, I have chosen to read them alongside each other in order to reduce the risk of ascribing any undue influence to individual reports that deviate from the general direction of travel. In light of the overarching aim of the study - to examine the ideal of equality in educational policies in the post-war period - the distinction between official reports and Government bills is of secondary importance. Rather, I will read the various documents as manifestations of underlying ideological impulses, where the empirical materials are understood as carriers of political impulses over time, which are discernible via the interplay of diachronic analyses and the mode of theorization pursued. Therefore, as I will elaborate on in the methodological considerations, only by way of theorising can we disengage the desires and convictions reified in the artefacts. Following Arendt, I consider the texts as "frozen thoughts", which we can defrost and thereby understand the complex of forces that help to form a specific society at a given moment in history. 55

So far, I have argued why I believe that the selected material is particularly well suited to illuminate the problem of the thesis. But it is worth noting the possible alternatives that I could have chosen, either as a complement to or as a substitute for the actual material. One alternative would have been to flesh out my findings by analysing teachers' journals, such as Skolvärlden with origins in the secondary grammar school teacher's organisations, and/or Lärarnas tidning, which was the journal for elementary school teachers.

By including these in my empirical material, I would have been able to give a synchronically richer and more extensive depiction of the changing role of teachers during the post-war period. But, in contrast to my preferred approach, in doing so I would not have been able to elaborate on the categories emerging out of the empirical studies and explore how they could be related to other, structural, societal changes. Therefore, as enriching as such a synchronically more comprehensive approach would be, it would have provided answers to other questions than the ones posed in this thesis. That said, and as I will comment on further in due course, the specific form

${ }_{54}$ Hannu Semola, "Construction of the Finnish Teacher in the National Steering Documents of the 1990s. Tasks and Qualifications", in Kirsti Klette, Ingrid Carlgren, J. Rasmussen, Hannu Simula, \& M. Sundqvist (eds.), Reform Policy and Teacher Professionalism in Different Nordic Countries (Oslo: University of Oslo, 2000).

55 Hannah Arendt, "Thinking and Moral Considerations: A Lecture", Social Research 38.3 (1971): 431. 
of diachronic analysis that I pursue here is limited insofar as its results come at the expense of the evident tensions in each individual report.

\section{Delimitations in time}

The official material constituting the lion's share of the empirical material stretches across the period 1945-2000. I have, however, also decided to include one commission before the outbreak of the war: namely The School Commission of 1935, which was summoned to discuss and present a proposal regarding an eventual seventh compulsory school year. I wanted to include this commission since it could help to throw into sharp relief the post-war tendencies. The report of 1935, and to a lesser extent, the major school commission of 1940, thus both serve primarily as a background to the main period in focus: the reforms of the post-war period up until the teachers training reform of 2001.

By focusing on the period from the school commission of 1946 and onwards, I follow a well-trodden path within the field of educational history. ${ }^{56}$ I have considered including the discussions from the early twentieth century, starting with the school commission of 1918, whereby a clearly discernible critique was articulated against the class-segregating effects of the parallel school system. These early manifestations of the critique of the educational system were, nevertheless, of a different character, embedded in ideas of the relation between individual, collective, and equality, which hark back to ideas of the previous century rather than embrace those notions of equality that emerged in the post-war period. ${ }^{57}$

The delimitation forward in time is the teacher's training reform of 2001. I have, by implication, chosen to omit the cycle of reforms launched by the liberal government between 2008 and 2011, including both new curricula and a new teacher's training reform. There is one major reason for leaving these outside the concerns of the present thesis: this cycle of reforms was of such a character that it could not have been included here without substantially modifying the whole shape of the study, in particular the endeavour to pursue the historico-political approach, as it would have circumscribed my possibilities to vertically qualify my empirical results. "Such a character" can be understood as a relative description: what I mean by this is that the reforms were interwoven into discourses, which, in some respects, contrast with the educational reforms of the preceding decades. Thus, in order to adequately frame these reforms, I would have been obliged to pursue at least

56 Boman 2002; Börjesson 2016; Englund 2005; Richardsson 1983; Wahlgren 2002, to name but a few examples.

57 For examples of this, see in particular "In Praise of the Present". 
one additional study to empirically substantiate my claims, which would have curtailed my possibilities of furthering the politico-temporal implycations of my findings. However, in order to outline how I maintain that the presented results interlock with the last wave of reforms, in the conclusion I will tentatively indicate why and how I believe that the most recent cycle of reforms ties in with the present results; but I will do so more as an attempt to signal possibilities for future research than to substantially contribute to the understanding of these reforms..$^{58}$

Against these limitations, both backwards and forward in time, it might be objected that the arguments presented herein rest on an artificial distinction between two aspects that, strictly speaking, are not separable: (i) the object of the study; and (ii) the delimitations in time. Is it not the case that the latter constitutes a moment in the articulation of what constitutes the very scientific object? It is to such questions around the normative conditions of history writing, and its relation to political theory, that we will turn in the following section.

\section{Method}

The purpose of this section is to define the normative conditions of the present study. Drawing primarily on the German historical theorist Jörn Rüsen's reflections on conditions of justification in historiography, I will discuss how these problems are addressed here. His reflections offer useful analytical tools that can help to explicate and conceptualise the practice of historiography in which I engage, and, by extension, thereby hopefully maintain an openness towards competing understandings. ${ }^{59}$ That said, Rüsen's reflections will be mobilised merely on the level of the general structure of the thesis. They will serve as a meta-theoretical framework via which the overarching narrative emerging out of the separate studies can be related to competing ways of explaining the problems addressed herein. Thus, it will not be at play within the separate studies, where different strategies have been applied - hence the denomination "meta-theoretical". But before turning to the primary questions regarding the conditions of the study, some further remarks on the question of context are in order.

As the historian of ideas Victoria Fareld puts it, contexts are mutable forms:

58 Although, it should go without saying, the results presented here clearly have implycations for how the last cycle of reforms might be understood.

59 In this regard, I contend, it can be understood as a form of ideology analysis, cf. Geuss 1981; Sven-Eric Liedman, Surdeg (Stockholm: Författarförlaget, 1980); Sven-Eric Liedman \& Ingmar Nilsson, Om ideologi och ideologianalys: uppsatser och texter (Göteborg: Institutionen för idé- och lärdomshistoria, 1989). 


\section{INTRODUCTION}

The arrangement of the historical material into a coherent story consisting of different contexts is at the centre of the historian's activity. A remaining question, however, is of what this arrangement more precisely consists: which contexts are taken as offering an understanding of the text? The question and the variety of possible answers reveal the constructed and ambiguous character of the context. ${ }^{60}$

A crucial aspect of Fareld's reasoning is that any a priori ties that bind the object to the temporal delimitations $\mathrm{x}$ and the spatial delimitation $\mathrm{y}$ do not exist: they must be created. In this regard, Hayden White has famously claimed that there are "as many equally plausible versions" of narrative representations "as there are plot structures available in a given culture for endowing stories". ${ }^{61}$ Against this far-reaching relativism, Fareld emphasises the importance of a reflexive stance vis-à-vis the context within which one writes, as well as that to which the object of inquiry belongs. As I shall discuss further below, not all positions are equally plausible or valid. The writing of history is not exclusively about representation; it also includes a cognitive dimension. ${ }^{62}$ If we concede (and I think we should) that there is an "epistemological ground for qualitatively distinguishing between different historical claims", then questions over the criteria of validity and norms immediately arise, through which we can navigate between various ways of approaching the past. ${ }^{63}$ Later, I will address these problems by first discussing how I have tackled the question of contexts. But in the remaining part of this section, the discussion will revolve around the questions of validity and norms that have a bearing on the present thesis.

The diachronic strategy to examine my chosen material has the advantage of comprehending the discernible phenomena as becoming rather than being. This way of reading can be contrasted to other forms of contextualising, such as synchronic-oriented discourse analyses, as well as the closely affiliated forms of series of synchronic analyses stretched out over time. The difference between the procedure of the present study and such competing modes of analyses can be illustrated by comparing the reforms around 1990 . By a synchronous analysis, focusing on how various concepts are related to each other - e.g. by analysing how different signs via "articulations" in, let's say, the curriculum of 1994 and the cluster of reforms that around 1990 saw the light of day - we can demonstrate how the various parts can be cemen-

60 Victoria Fareld, "Contexts in Flux: Textual Concerns for the Historian of Ideas", Ideas in History 2.3 (2007a): 55.

61 Hayden White, “Historical Pluralism”, Critical Inquiry 12.3 (1986): 489.

62 Fareld 2007a, 52.

63 Fareld 2007a, 52. 
ted into a chain of equivalence, which is then ascribed a certain meaning. ${ }^{64}$ Essentially, this holds both for discourse analyses focusing on one sequence of time and those focusing on a number of sequences: in either case, the method remains ungainly when we wish to analyse transmutations over time as they are transforming. It is for this reason that I maintain that the form of diachronic analysis adopted here creates opportunities to reveal how the ideal of equality as a politico-temporal category has been articulated throughout the post-war period.

That said, I do not wish to imply that diachronic studies per se are preferable to synchronic studies (or series of the same genre); which of these two forms one opts for must clearly be decided with regard to the purpose of the study at hand. The present thesis should thus be read as a complementary rather than mutually exclusive contribution to the number of studies that - with regard to different theoretical perspectives - focus on different points in time.

As hinted at previously, an obvious example of where a synchronic approach would be preferable is when we wish to accentuate the various tensions that always, at any given moment in time, intersect policy documents. In any document, analysed within the context out of which it emerged, we will always be able to discern conflicting convictions and desires. Virtually all policy documents can be read as discursive battlefields, with conflicting wills pulling in different directions. If this were the aim, I could also have focused on how equality appeared in other policy documents. ${ }^{65}$

64 Cf. Chantal Mouffe and Ernesto Laclau, Hegemony and Socialist Strategy: Towards a Radical Democratic Politics (London: Verso, 1985), 105ff.

65 In, for example, the 1990 s a debate broke out regarding precisely the concept of equality in light of the increasing proportion of people with roots in other countries, propelling discussions of new forms of envisioning equality, such as what cultural equality might mean. On a policy level, we find manifestations of this in, for example: SOU 1996:143, Krock eller möte - om den mångkulturella skolan (Stockholm, 1996); SOU 1997:121, Skolfrågor - Om skola $i$ en ny tid (Stockholm, 1997); SOU 2006:40, Utbildningens dilemma demokratiska ideal och andrafierande praxis (Stockholm, 2006). In the wake of these changes, a number of studies have been made addressing the same theme. To mention just two such examples, see: Pia Nykänen, Värdegrund, demokrati och tolerans: Om skolans fostran i ett mångkulturellt samhälle (Stockholm: Thales, 2009); Joachim Rosenquist, Pluralism and Unity in Education: On Education for Democratic Citizenship and Personal Autonomy in a Pluralist Society (Örebro: Örebro Universitet, 2011). For an intriguing philosophical analysis of the historical antecedents and revival of the related concept of recognition, see: Victoria Fareld, Att vara inom sig utom sig: Charles Taylor, erkännandet och Hegels aktualitet (Göteborg: Glänta, 2007). For an analysis of how the emergence of recognition could be understood with regard to the previously dominant demands for redistribution, see: Nancy Fraser, "Social Justice in the Age of Identity Politics: Redistribution, Recognition, and Participation", The Tanner Lectures on Human Values, delivered at Stanford University, April 30-May 2, 1996. However, as indicated by the aim, this debate falls outside the purview of this thesis. 


\section{INTRODUCTION}

Indeed, such analyses, where the discernible tensions between competing forms of temporally charged equality within separate policy documents, would be an excellent way to enhance and further the present findings. ${ }^{66}$ But again, approaching them in this way would have been a completely different study, focusing primarily on the open-ended discussions within a particular sequence in time, for example, within the various documents on which I draw. From the vertical historico-political approach, including both historical and political theoretical considerations, giving form to this study, it follows that such horizontal qualifications fall outside of its scope.

Therefore, given the purpose of the present thesis - to discern how equality as a politico-temporal problem appears in educational policies throughout the period - I maintain that the most conducive way to understand the material is to read it as a form of temporally extended discourse, discernible first when approached in a diachronic fashion. Thus, I do not read the documents within the confines of the ongoing educational debates of which they form a part, but rather as manifestations of an ongoing and remodelling discussion on the role of education in society. ${ }^{67}$ The chief purpose of reading them in this fashion is that it allows me to grasp the central object - equality as a politico-temporal problem - as a chronologically expansive political impulse. ${ }^{68}$

As stated, two of the four articles are empirically oriented, whereas the other two serve to theoretically elaborate on the empirical findings. In virtue of the historico-political approach via which I have chosen to examine the problem, the compilation form of the thesis offers a major advantage, as it allows me to focus on various aspects of the central problem individually in sequence. This is a crucial benefit of the present thesis, as it enables greater opportunities to elaborate on the historiographical and politicotheoretical themes in a more systematic form in studies 3 and 4 .

66 Quentin Skinner's reflections on how the meaning of specific texts are analysed against "the precise cultural contexts in which they were originally formed" is telling in this regard, see: Quentin Skinner, Visions of Politics, Volume 1 (Cambridge: Cambridge University Press, 2002), 125. By tackling the documents within a narrower, synchronic division of time, we could address a vast array of questions to which, in the words of Collingwood, "the thing [ ...] said or written was meant as answer", see: Robin George Collingwood, An Autobiography (Oxford: Oxford University Press, 1939), 31.

67 Cf.: Linn Spross, Ett välfärdsstatligt dilemma: Statens formuleringar av en arbetstidsfråga 1919-2002 (Uppsala: Acta Universitatis Upsaliensis, 2016), $27 \mathrm{f}$.

68 A further methodological advantage of reading them as such is that it diminishes the risk of ascribing undue weight to more peripheral ideas, i.e. ideas that do not recur in other policy documents. Another, already indicated, strategy for limiting this risk that I have also applied is to read the reports alongside Government bills and, to a lesser extent, school curricula. 
At the same time, however, as noted above, this method does also curtail my possibilities of accentuating the tensions discernible at each given moment in time, within each policy document. Clearly, defining the relevant context will inevitably hinge on the purpose of the study. It should therefore be stressed that the analysis pursued here makes no claims regarding the ongoing struggles behind each document. Without paying due attention to this limiting factor, the reader might get the impression that the perceived impulses were predestined, as if forces beyond the political actors involved. For obvious reasons, which I will elaborate on when establishing how my findings tie in with previous research, this is not how I understand them. As mentioned, I read them rather as the outcomes of political struggles, as artefacts from which we can evince certain political impulses over time. My focus is therefore on political positions that have proven to be influential, not the political struggles behind their advancement at any given moment in time. ${ }^{69}$

As an example, the historico-political approach endorsed here could be seen to supplement rather than compete with existing perspectives, much like Pierre Bourdieu advocated analysing the history of a phenomenon not as a fait accompli, but rather as the:

[...] product of strategies (conscious or unconscious) oriented towards the satisfaction of material and symbolic interests and organized by reference to a determinate set of economic and social conditions. Once one forgets all that is implied in extracting from the product the principles of its production, from the opus operatum to the modus operandi, one condemns oneself to proceed as if the regular product had been produced in accordance with the rules. ${ }^{70}$

69 Where a focus on the latter would have necessitated a horizontal analysis, and would have foregrounded the competing understandings that could have been discerned at any given point in time. This reading strategy closely corresponds with the distinction made by the Swedish historian Bo Stråth, inspired by Koselleck, between past futures and present pasts: “[ ...] past futures is an alternative to the application of the retrospective analytical concepts outlining present pasts. The argument is that the focus on past futures outlines historical processes in their ambiguities, contradictions, oppositions and openendedness, whereas the focus on present pasts tends to confirm the history that actually happened and ignores the potential alternatives." Clearly, the present study bears many traits of what Stråth calls a present past, since my focus is on tendencies that proved to be influential, and this, to some degree, operates at the expense of the open-endedness that is notable in studies focusing on the tensions intersecting separate political documents be they policy documents or of any other form. See: Bo Stråth, "Identity and Social Solidarity: An Ignored Connection. A Historical Perspective on the State of Europe and its Nations", Nations and Nationalism 23.2 (2017): 227-247.

70 Pierre Bourdieu, Outline of a Theory of Practice (Cambridge: Cambridge University Press, 1977), 36. 
To the extent that researchers within the Bourdieu-tradition do not reduce our understanding of social phenomena to analyses of agents' strategic action - be they individuals or collectives - I cannot, in my approach, see any intrinsic qualities that would prevent the results from being taken further by such studies. On the contrary, I believe that such analyses should be read alongside my own results. ${ }^{71}$ The two reading strategies appear rather like two different techniques of tackling the educational system as a general object of analysis in the humanities and social sciences.

\section{The Historico-Political Approach: Between Historiography and Political Theory}

With regard to the relationship between empirically oriented history and "pure" empirically detached political philosophy, this thesis takes a middle position. ${ }^{72}$ Indeed, as I have hinted at previously and will further explore below, the very historico-political approach informing this study serves to bridge the gap between abstract political philosophy and strictly empirical research which always runs the risk of becoming myopic. This is a key assumption behind the vertical approach.

Instead, I maintain the importance of examining material in ways that do not bend to the vagaries of the punctual now, but rather, via historicopolitical reflections, bring to the surface those slower-moving impulses that escape "the unmediated experience". ${ }^{33}$ Put differently, only by theorising can we render possible a richer and more nuanced understanding of the manifest expressions within the policy documents. It is in this sense that the third and fourth studies, as well as the advancing of the analysis in the concluding section, serve to expound the wider implications of the impulses identified in the empirical studies.

71 However, when they do reduce their analyses to the outcomes of strategic actions, they appear more like a sociologically informed branch of the Rational Choice school. For an outline of one of the major proponents of this tradition, with a focus on, e.g., educational issues, see Gary Becker's Nobel Speech, "The Economic Way of Looking at Life", held December 9, 1992:

www.nobelprize.org/nobel_prizes/economic-sciences/laureates/1992/beckerlecture.pdf. For an overview of Becker's theory from an historical perspective, see: AnnChristine Dellnäs, Om ekonomisk imperialism - En studie av Gary S. Beckers idéer om humankapital, familj och kriminalitet (Göteborg: Institutionen för idéhistoria och vetenskapsteori, Göteborgs universitet, 2002).

72 Jonathan Floyd \& Marc Stears (eds.), Political Philosophy Versus History? Contextualism and Real Politics in Contemporary Political Thought (Cambridge: Cambridge University Press, 2011).

73 "die sich der unmittelbaren Erfahrung entziehen", Reinhart Koselleck, Zeitschichten. Studien zur Historik (Frankfurt: Suhrkamp, 2000), 39. 
The relationship between historiography and political theory can be expressed as a question about what claims historians can rightly make. In the discussion that follows, I will take as my point of departure some reflections by the German historiographer Jörn Rüsen on the conditions of writing history. In so doing, I can show how the present study can be related to other approaches, as well as how I conceive of it with respect to history writing and political theory. This is particularly pertinent given that the object of the study remains at the heart of contemporary educational debates.

Rüsen's starting point is that history is to be understood as a field where recollections are interwoven with expectations, where we "relate experiences of temporal changes to intentions of action". ${ }^{74}$ Thereby he emphasises how all writing of history could be understood as Janus-faced, insofar as we must simultaneously look to the past and the future. It should, Rüsen maintains, be envisioned as an articulation of various narratives where historians "try out the future in practice via the past". ${ }^{75}$ With this, he attempts to narrow down the vital role that history writing plays in our attempts to orient in the present, where reconstructions of the past are crucial. But he also stresses how the practice is related to future-oriented questions concerning which paths we ought to prefer and pursue. More specifically, Rüsen notes how the various ways in which we narratively relate to the past, and thereby anchor ourselves in time, are central to the articulation of our identities, and how the past as such conditions our possibilities for action.

Out of these assumptions, Rüsen discerns three different but closely related dimensions of history writing. The first dimension pertains to the empirical foundations, and the uncontroversial claim that all competing historical narratives regard facts, that is, experiences of events in the past: something turned out this way and not that way. Rüsen refers to this as the dimension of experience, and this is where the muteness of the artefact is transformed into history by being woven into a temporal then and now by way of an interpreter. Of course, one must also recall that these artefacts are merely splinters or fragments left behind by the past, and as such must not be confused with what once happened. ${ }^{76}$ As one of Rüsen's primary sources

74 "relaterar erfarenheter av tidsliga förändringar till handlingsavsikter", Jörn Rüsen, Berättande och förnuft: Historieteoretiska texter (Göteborg: Daidalos, 2004), 62.

75 “prövar framtiden i praktiken med hjälp av det förflutna”, Rüsen 2004, 61.

76 As Michael Oakeshott puts it in his reflections on the task of the historian, history is constituted of relics. Independently, qua an object at hand, any such remnant is an indisputable fact, but "in respect of being a survival from the past its authentic character is a matter for enquiry”, Michael Oakeshott, On History (Indianapolis: Liberty Fund, 1999), 39. 


\section{INTRODUCTION}

of inspiration, Gustav Droysen, puts it, the remnants ought to be understood:

[...] ideally [...] as faded traces and suppressed gleams. Apart from knowledge these are as if they existed not. Only searching vision, the insight of investigation, is able to resuscitate them to a new life, and thus cause light to shine back into the empty darkness of the past. Yet what becomes clear is not past event as past. These exist no longer. ${ }^{77}$

It is first through our active reconstruction of the vestiges left behind by events in the past that the past itself can be "resuscitated". ${ }^{78}$ And, as noted, this thesis is not the result of new empirical material, but instead realises previous research by showing how we can enhance our understanding of the problem at hand via the historico-political approach.

Alongside the artefacts serving as the empirical ground of the research questions, history writing inevitably comprises norms through which we select among all that could have been transformed into history; something ought to be one way rather than another. What Rüsen calls the dimension of meaning, the second dimension, is constituted of norms and values, which the interpreter can use to help decide on what to include and exclude from what has happened. It is concerned with the normative validity of the narrative. ${ }^{79}$ In focus are questions regarding how the selection of material has been made, which questions are posed, what is foregrounded, etc. The author should here address how her narrative can help us orient ourselves in the contemporary world. In motivating her choices, the author should be able to point to which normative questions the perspective depends on, and why this is desirable. To answer such questions, she must inevitably draw on normative arguments, short of which she will not be able to legitimate her perspective and explicitly address how history writing interrelates with both the present and the future.

Both of these - the empirical dimension and the dimension of meaning can be understood as conditions for history writing. In order to fulfil both, we must examine the remnants of past events and discursively defend why our way of tackling the issue at hand is the most desirable way. For example, if we take as our normative point of departure a perspective whereby the past from the outset is stigmatised in accordance with some form of Whiggish idea of a presupposed development, it seems unlikely that we will satisfy the dimension of experience. Instead, the latter seems to have been

\footnotetext{
77 Johann Gustav Droysen, Outline of the Principles of History (Australia: Leopold Classic Library, 2015 [1893]), 11.

78 Droysen 2015, 11.

79 Rüsen 2004, 67.
} 
made to conform to our current norms. As we shall see, key tenets in the post-war educational ideals, as well as some interpretations in the current debate, manifest some of these characteristics, where the past - as less developed, less democratic, and more hierarchical - is articulated as a negative discursive counter-image. ${ }^{80} \mathrm{~A}$ severe problem with this form of approaching the past is that it seems to render us poorly equipped to at least evaluate how and in what senses the past continues to structure our present - including aspects of the past that we might wish to have been different. At the same time, however, it does not seem desirable for historical studies to be completely detached from the actual surrounding society; we want history to serve the conservation of "historical sense", not to "mummify life". ${ }^{81}$

In my view, a more fruitful way to approach the past is to strive to approach it in dialogue with the present; dialogical in a way that to some extent corresponds to the tradition of magistra vitae, where we, as Arendt described it, turn to the past in order to have it shed light on the present. ${ }^{82}$ But also dialogical with the purpose of explicating, and thereby rendering more dynamic, how the past continues to structure our present through what Rüsen refers to as "dormant traditions". ${ }^{83}$

Alongside and out of these two conditions of reliability - the criterion of experience and the criterion of meaning - Rüsen discerns a third dimension: namely the criterion of narrative credibility. With respect to the two preceding conditions, the third has a synthesising function by threading together the other two into one historical narrative with its own aim and structuring ideas. The purpose indicates how, to what, and to whom the narrative relates. ${ }^{84}$ What characterises historical narration, besides the two aforementioned dimensions, is the need to embed our findings in a narrative. In this sense, White's point that history, in light of its narrativity, is not "out there", is indeed very illuminating. ${ }^{85}$

80 In this regard, it can be compared with what Arendt refers to as a form of process thinking, see: Hannah Arendt, The Origins of Totalitarianism (New York: Schocken Books, 2004), 604ff.

81 "historiska sinnet"; "mumifierar livet”, Friedrich Nietzsche, Otidsenliga betraktelser (Stockholm: Symposium, 2005), 98.

82 Hannah Arendt, Men in Dark Times (USA: Stellar Classics, 2014), 205.

83 With which he means the strands of continuity that pervade us in the form of unconscious elements in our culturally rooted mental life. See: Jörn Rüsen, "Tradition: A Principle of Historical Sense-Generation and its Logic and Effect in Historical Culture", History and Theory 51.6 (2012): 45-59.

84 In this regard, it does call to mind White's distinction between descriptive and interpretative categories, see: White 1986, 487.

85 White 1986, 487. 


\section{INTRODUCTION}

The study should thus be read and evaluated not only as another historiographical narrative alongside a range of other narratives about our past. Rather, my ambition is to argue in favour of history writing as a collective practice in which the participants together aim at - via each and everyone's particular contribution - jointly maintaining a living relationship to the past. ${ }^{86}$ Indeed, as Fareld remarks, it is precisely by emphasising the narrative and constructive dimensions of the past that we can help to maintain it as a living and transforming reality, and hence ensure that it does not become reified into something detached from us. ${ }^{87}$

To sum up, Rüsen defines the qualitative criteria for history writing as: (i) intersubjective evaluability, by explicating how the results have been reached (the empirical dimension); the extent to which it is capable of (ii) reflecting on the normative substance of the narrative (which should aim at extending our perspectives); and (iii) that it is capable of theorising the findings, i.e. that the historian is able to bind together facticity and meaning into a coherent narrative, where the specificity of historical narratives is that they explicate and substantiate their claims. And since, as previously explained, this study serves primarily to qualify our understanding vertically, it is the two latter criteria that I will focus on when returning to the Rüseninspired framework in the concluding section.

In the conclusion, in the second section, I will return to Rüsen and mobilise some of his insights in order to highlight how my results interlock with previous studies in the field. In addition, I will set out how the analytical categories of the separate studies relate to the dimension of experience (by claiming that something has happened), the normative dimension (which we satisfy by addressing questions of relevance for our self-understanding), and finally, at a more overarching level, the narrative reliability. ${ }^{88}$ In the following section, I will show how this way of envisioning the practice of history writing is in contrast to perspectivist approaches.

86 Moreover, and to be precise, understanding history in this way "entails an openness to contemporary appeals by letting new interpretations appear that transcend the origins of the historical text", Fareld 2007a, 52f.

87 Fareld writes that the "very practice of writing history, taken as a continuous, incessantly changing and dynamic actualisation of the past into the present, can therefore be understood as what secures the autonomy of the past", Fareld 2007a, 48. See also Walter Benjamin's Sixth Thesis on history: “[I $]$ n every era the attempt must be made anew to wrest tradition away from a conformism that is about to empower it [...] Only the historian will have the gift of fanning a spark of hope in the past who is firmly convinced that even the dead will not be safe from the enemy if he wins. And this enemy has not ceased to victorious." Walter Benjamin, Illuminations: Essays and Reflections (New York: Schocken Books, 1999), 255.

Rüsen 2004, 66. 


\section{Excursus I: Theory and Theorising: A Brief Remark on Perspectivism}

The outlined point of departure should be contrasted with the idea that history writing is about the articulation of a narrative tailored for the group that one takes to represent, and with an explicit scepticism towards - if not downright dismissal of - the desirability of a shared narrative. ${ }^{89}$ The solution here seems to be that we accept and promote the idea of different narratives existing as incommensurable monoliths alongside one another. A serious flaw in this way of thinking about the writing of history is the constraint on our reflexivity that it risks engendering, since advocates for competing perspectives are invited to content themselves with striving for coherence merely with regard to the premises of their own perspective. An essential distinction in this regard is the separation between theory as the application of a fixed scheme, and the practice of theorising as the development of a theory by having empirical data interact with conceptualisations..$^{90}$

Drawing inspiration from the work of Rüsen, the Swedish intellectual historian Martin Wiklund has made a useful distinction in respect of the importance of theorising without merely reproducing one's own ideological convictions. ${ }^{91} \mathrm{He}$ also stresses the difference between various ways of instrumentalising the past, in particular the line of demarcation separating

89 This is something that the Swedish sociologist Donald Broady has aptly described as "additive critique", defined by "reproaches such as: here we are missing a class perspective, a gender perspective, an actor perspective, a macro perspective, a micro perspective, an in-between perspective. As a rule, the absence of the perspective that the critic herself happens to endorse." See: Donald Broady, "Det svenska hos ramfaktorteorin”, Pedagogisk forskning $i$ Sverige 4.1 (1999): 115.

90 Richard Swedberg, "Before theory comes theorizing or how to make social science more interesting", The British Journal of Sociology 67.1 (2016): 5-22; Mikael Carleheden, "What conception of the theoretical does 'theorizing' presuppose? Comment on Richard Swedberg's 'Before theory comes theorizing or how to make social science more interesting'”, The British Journal of Sociology 67.1 (2016): 36-42. As Carleheden reminds us, the "application of ready-made theory may obscure rather than disclose the world", Carleheden 2016, 37. For a blistering but brief critique of the role that Theory has come to play in academia, see also: Barbara Carnevali, "Contro la Theory. Una provocazione", www.leparoleelecose.it/?p=24320.

91 Martin Wiklund, Historia som domstol: Historisk värdering och retorisk argumentation kring "68" (Nora: Nya Doxa, 2012); Martin Wiklund, "Ett ansvarslöst ansvar? Om historikerns ansvar för historiska lärdomar”, in Patricia Lorenzoni \& Ulla Manns (eds.), Historiens hemvist, vol. II: Etik, politik och historikerns ansvar (Göteborg/Stockholm: Makadam, 2016), 193-216; Martin Wiklund, "Meaning in History Beyond Instrumental Rationality: The Concepts of Meaning and Rationality of Meaning in Jörn Rüsen's Theory of History", Ideas in History 2 (2008): 57-86. 


\title{
INTRODUCTION
}

that the past is used and how it is used. ${ }^{92}$ The usage of the past as such, Wiklund argues, is not a problem in itself. However, when used to confirm a readymade ideological scheme with its own desiderata, it risks becoming merely an instrument serving to reproduce a preordained theoretical perspective and its concomitant worldview. In such a situation, the evaluation of historical knowledge - i.e. whether the claims are justified and motivated or rather distorting and deceptive - runs the risk of being reduced to whether or not the normative conclusions are congenial to one's own ideological premises. ${ }^{93}$

At the same time, we must, as White has remarked, bear in mind that "all knowledge produced in the human and social sciences" lends itself better to "a given ideology better than it does to others". ${ }^{94}$ Along the same lines, it is reasonable to assume that what in a given period is deemed plausible is also socially conditioned:

\begin{abstract}
What is plausible, we know since Freud, is that which conscience, the distillation of social authority, tells us we should desire against that which need or instinct tells us we desire. The plausible is the distillate of the conflict between social restraints, introjected as the "symbolic system" of the culture to which we belong, on the one side, and the "imaginary", acting under the impulsions of the libido and instincts, on the other. ${ }^{95}$
\end{abstract}

Following White's remark, it is therefore judicious, or precisely plausible that that which in a given society is considered to be plausible is conditioned by the prevalent class structures of that society. If, however, we, as White does in the same article, take it to be a "socially given category" (my italics), it appears as if the "plausible" is reduced to an effect of the current power structures in the society at hand (where class relations are merely one of a plethora of competing categories of relevance). ${ }^{96}$ Thus, when intersubjectivity is not even maintained as an ideal to pursue in terms of the incessantly moving object of the past, we run a severe risk of increasing the gulf between theory and experience, and, as a consequence, between ourselves and the world. In treading this path we risk ending up in a situation where understanding is reduced to us being able to "understand the consistency of

92 Martin Wiklund, “Den historiska kunskapens praktiska ändamål”, Scandia 79.2 (2013): 113-124.

93 Wiklund 2013, 120.

94 Hayden White, The Content of the Form: Narrative Discourse and Historical Representation (Baltimore: Johns Hopkins University Press, 1990), 81.

95 White 1990, 94.

96 It should be added that occasionally White himself argues in a way that bears a surprising resemblance to the inflexible vulgar-Marxism that he himself so convincingly criticises, see e.g.: White 1990, 93. 
arguing and reasoning, of the process of argumentation in its sheer formality", thereby opening up an insurmountable abyss between the terminology within our subgroup - "it follows from our premises..." - and the world. ${ }^{97}$

In contrast, I maintain that the Rüsen-inspired manner of envisioning the practice of historiography offers better preconditions with which to address the problems defined by White; better in virtue of unpacking the various (normative and other) moments in different narratives. Whereas White seems to want to dissolve the ideal of veracity as such in favour of narrative pluralism, I maintain that Rüsen's approach offers tools for explicating, and thereby making us more aware of, our underlying premises.

97 Arendt 2006a, 95-96. 


\section{Summary of Articles}

\section{(1) "In Praise of the Present: The Pupil at Centre in Swedish Educational Politics in the Post-War Period"}

(History of Education 46.6 (2017): 768-787)

The first empirically oriented study focuses on the individual pupil. I identify how the post-war ideal of placing the pupil at the centre of the educational process changed throughout the period. The problem is assessed via an examination of how the individual pupil was articulated in relevant policy documents between 1935 and 1992. In order to refine the problem, I approach it indirectly through three external reference points: the teachers' assumed authority; the role ascribed to the cultural heritage; and the forming potentiality of the subjects studied.

By analysing how the ideal of centring the individual pupil was transmuted in policy documents throughout the period, I touch upon the muchdiscussed question of individualisation during the post-war period. As an analytical tool for rendering the inner shifts within this general tendency explicit, I mobilise what the French historian François Hartog calls "regimes of historicity". The concept refers to the various forms in which societies and/or cultural spheres install and deploy themselves in time. As such, it can be seen as an expansion of Reinhart Koselleck's reflections on the new ways in which spaces of experience and horizons of expectation became intertwined in the second half of the eighteenth century.

Historiographically, the purpose is to qualify an influential narrative, according to which the Swedish educational system underwent a drastic change during the 1990s, moving towards a more individualistic and marketised system. Without denying the relevance of this perspective, I supplement this narrative by arguing that we can trace antecedents to the reforms undertaken in the 1990 s far back in post-war educational policies. I argue that the introduction of a voucher system in the early 1990 s could partly be considered as a response to a critical impulse that goes all the way back to the school commission of 1946, with a noteworthy shift of emphasis occurring from the 1970s. I contend that an increased focus on what was at hand 
in the present - at the individual level of the pupil, as well as at a societal level - gradually replaced the previously dominant ideal of preparing pupils for the future. Thus, where preceding research has tended to emphasise how the reforms around 1990 signal a rupture of post-war educational policies in Sweden, I stress the hitherto overlooked aspects of continuity.

In 1948, cultural decay was still a threat to the commissioners, and childcentred learning appeared primarily as a means. In the report of 1985, with its strongly emphasised generation-based idea of equality, the tone had changed. This, I maintain, is a shift of nuance that can be reconstructed via two related ideas. First, we are facing a manifestation of the progressivist conviction that pupils learn by doing things, i.e. that practicing democracy here and now is the best way to prepare pupils to become democratic subjects. Secondly, I argue that we can discern an equality-promoting idea emphasising each pupil's right to exercise more influence over their education qua members of the democratic community. When radicalised, these two convictions - the pedagogical (the former) and the ideological (the latter) can be understood as expressions of what Hartog describes as a presentist regime of historicity. When interpreted in this manner, taking into consideration the increasingly radical attempts to further the democratisation of the educational system, the reforms around 1990 appear less like a rupture; they now appear more like the outcome (as unexpected as it was unwanted) of the fervent attempts to advance the process of democratisation.

Hence, in the first phase, school was deemed the primary arena for preparing pupils for a community that both preceded and outlived them. The way into the future for pupils went through the past in the form of, for example, cultural heritage; the task of the comprehensive school (Enhetsskolan) was to give as many pupils as possible an opportunity to take part in this. This is a manifestation of a modern regime of historicity, where the future dictates whether and why certain restrictions are necessary; the pupil needs to be subjected to this in order to become a citizen and develop a "harmonic" personality. Until the 1970s, this view dominated policy documents.

In the second phase, the pupils were successively transformed from potential future citizens to incarnations of a more direct route to the new, more equal and democratic society. This was due in part to the radicalisation of progressivism and an increased inter-generational idea of equality. The very same ideals therefore now became forces to loosen up what they had inspired to construct 20-30 years earlier. In facilitating the shift towards the particular in the form of the pupil and her/his parents, and/or the local school, the radicalisation started to undermine what had previously been built up; and this under the aegis of the principal aim to further democratise the educational system and make it more equal. By implication, the same 
ideals thus turned against the very same (future-oriented) premise on which they had originally been founded. In the concluding section, I flesh out how these transmutations can be conceived of in political terms by employing two different conceptions of the term "equality" in educational terms, as developed by the French philosopher Marcel Gauchet.

\section{(2) "The Paradox of Democratic Equality: On the Modified Teacher Role in Post-War Sweden"}

(Confero 5.1 (2017): 193-241)

In this article, I examine how the ways in which the ideal teacher has been envisioned, as well what she as teacher has been expected to achieve in her role, have changed throughout the post-war period. More specifically, I focus on how these ideas have been related to the goal of rendering school more democratic and equal. As my point of departure, I have chosen the school commission of 1946. I then advance all the way up to the teacher training reform of 2001.

The study should be understood as a counterpart to the previous article "In Praise of the Present". It marks an attempt to offer new perspectives on previous studies of the transformations of the teaching profession during the period, such as the effects of municipalisation, the proclaimed de-professionalisation of the teaching profession, as well as analyses made of teachers' social backgrounds from the end of the 1970s onwards. It has been convincingly shown that the changes analysed in these studies have had an effect on the teacher's authority. By analysing how the relevant questions have been posed in policy documents over time from an institutional perspective, I present new perspectives on how these reforms can be related to more thoroughgoing ideological shifts in society.

By mobilising Alasdair MacIntyre's analytical construct "character", as well as Arendt's conception of "the social", I focus on previously overlooked aspects of the changes. I argue that the strong pupil-centred education, an outgrowth of which was the introduction of the voucher system, can be related to a successively modified definition of the teacher's task since the school commission of 1946.

I assess the problem by examining (i) how the idea of what teachers are expected to do has changed, and (ii) how different organisational changes can be understood as implicit transformations in the teacher's tasks. The purpose is to illustrate how the perception of the reproduction of society through pre-university education has altered. The diachronic analysis of the changed role of teachers therefore aims primarily at shedding light on how the school qua institution has changed. 
From having been expected to pass on a selection of knowledge from the previous generations to the new, the teacher's ideal throughout the post-war period shifted towards that of providing stimulating support for pupils, who in turn were expected to flesh out the content themselves on the basis of their own preferences. Since today's content may be outdated by tomorrow at any rate, the supporting form becomes the primary task for teachers. That this has contributed to a weakening of the teaching profession has already been noted. What I try to draw attention to here is (i) how we can trace several of the long-term changes behind this shift to the foundational ideas behind the comprehensive school, as well as (ii) some hitherto insufficiently examined politico-temporal problems that these shifts have actualised.

In the preceding parallel school system, it was clear how different pupils (generally from different classes of society) were prepared for different occupations (which tended to be within the same social stratum as that of the parents). When the comprehensive school replaced the parallel school system, this was something that reformers hoped to do away with. However, as school critics already highlighted in the 1970s, it was not long before critique amassed in this regard against the new comprehensive school as well. One crucial policy retort to this criticism was to change the forms of school's internal work. In this way, the widely shared belief that school needed to be further democratised was further intensified. The desire to create a more equal school thus goes hand in hand with the explicit movement towards democratisation; a consequence of this was that the boundary between pupils and teachers became increasingly vague, manifested in the demand for teachers to adapt to the pupils' diverse experiences and backgrounds. This is the first border-dissolving tendency that I discern.

A second change, in the same vein, was the desire to dissolve differences between what were originally class and subject teachers. The third dissolving impulse that I highlight was the criticism of the dichotomy between practical and theoretical work. These shifts should, I maintain, be understood as materialisations of a different notion of school as an institution, which increasingly was being seen as part of the (democratic) public sphere. By so arguing, the reformers also advanced the private sphere within this peculiar "in-between" space; as such, it was a protracted shift that we have good reason to view as an expansion of the social. It is a manifestation of what the Dutch sociologist Anton C. Zijderveld describes as an increasingly anti-institutional modus, where common institutions are regarded as limitations of each individual's subjective identity.

Furthermore, by downplaying the content-oriented, imparting role of education, school practices engaged with the surrounding community, thereby undermining it as a specific site for the public preparing institution, 
and the teachers' positions within it. It is by virtue of representing the leading common institution that I maintain that the late modern teacher ideal should be regarded as a character.

Out of these shifts emerges what I call the paradox of democratic equality. The paradox consists in the fact that the intensified attempts to create a school inspired by a public-oriented logic, in a number of relevant respects, seem to have helped to pave the way for the clearly private-oriented logic that has characterised school development since the 1990s. As stated above, the post-war school policy was characterised by an effort to create a more democratic school: first through the comprehensive school, and subsequenttly in reforming the inner workings. However, a consequence of this impulse was that the common fabric into which the pupil was expected to be woven became more fragile, as the importance of articulating/reproducing a common backdrop - in the name of democratic equality - was downplayed.

\section{(3) "Tocqueville, Educational Politics and Individualisation: On the Democratisation of Post-War Educational Policies in Sweden"}

\section{(Lychnos (2018))}

As indicated, the two preceding, empirically oriented, articles serve to highlight previously overlooked strands of continuity in educational policies in the post-war period. I have argued that the reforms are indicative of new ways of envisioning the individual pupil with regard to the surrounding society, in the articles represented by teachers and in the content taught. Out of these studies, problems of a more theoretical and structural nature have emerged, and it is these that the third study seeks to address.

The purpose of this article is to elaborate on my findings from the previous studies by reactivating Alexis de Tocqueville's reflections on the promises and challenges of democratic society. Writing in the initial stages of the fledgling modern society, Tocqueville addressed challenges of a fundamental character that I believe can open up new perspectives on the transformations of pre-university education from 1945 until today. In particular, I note how his reflections on a specific form of individual-centred equality can enhance our understanding of the pervasiveness of a neoliberal logic in the educational sphere (and, indeed, in political life more generally) from the 1990 s and onwards.

I argue that a specific form of imagined (imaginaire) equality has been a crucial ideological component of the educational reforms, propelling a dismantling of different forms of substantial ideals in the form of qualitative distinctions, most notably manifested by disparaging the transmission of a 
given content and in nourishing a new role for the teacher. By qualitative differences, I refer to structuring ideals that transcend the individualist values of self-determination and positive rights. In virtue of representing something other vis-à-vis the individual, I refer to this shift as a withering of alterity as a structuring ideal in educational policies.

In order to structure the study, I distinguish four analytical categories: (i) democratic epistemology; (ii) opinion replacing authority: the transhistorical premise; (iii) temporal provincialism; and (iv) a shift from social to natural bonds. Through these four categories, I argue that a number of politically relevant facets of the educational reforms can be understood as, at least partly, internally engendered impulses. Emphasising a number of central dimensions of post-war educational policies, I argue that, in various ways, they evince a tendency to weaken political and strengthen interest-driven bonds. The democratic epistemology, temporal provincialism, and intimisation of upbringing all converge in a tendency to have individuals retracting into themselves.

The outlined undermining of alterity, I maintain, is another thread that connects the above policy changes. The implicit tendency to dismantle the idea of authority, the scepticism towards the disinterested (as opposed to that which serves a practical purpose) and towards engagement with the abstract and theoretical, to increasingly focus on what is present, to promote the natural at the expense of the artificial, can all be thought of as manifestations of a hostility towards alterity. The disassembling of qualitative distinctions and the increased importance ascribed to the present appear rather straightforward by virtue of manifesting a direct scepticism towards timebound and person-bound otherness. Regarding the abstract, it could be thought of as examples of alterity owing to their time-demanding, imperative, and subjectifying character; treading their inaccessible paths, without any fixed terminus, necessitates subjection to their premises, and this presupposes the acceptance of an initial inequality.

\section{(4) "Equality and Education: a Politico-Temporal Approach"}

\section{(Journal of Philosophy of Education (under review 2018))}

Drawing on the results of the first three studies - in particular the relation observed between the Tocquevillian imaginary form of equality and presentism - the relationship between the previous studies is further advanced here. There are two overarching aims that I set out to fulfil in this study: as indicated, first, it serves to elaborate on how the presentist temporal logic in educational policies appears to be entwined with a specific form of, following Tocqueville, imaginary equality. Building on the results of the preceding 
studies, I argue that the two discerned tendencies - the presentist regime of historicity and the imaginary form of equality - should be analysed as a single politico-temporal problem, and that this is crucial for comprehending what I have termed the democratic paradox. With regard to the study on Tocqueville, I flesh out in greater detail how the imaginary form of equality relates to competing conceptions of equality. Against this backdrop, the second purpose is to delineate a more politically fruitful way to think of educational equality, structured around a more politically tenable temporal logic.

I argue that Hannah Arendt's reflections on the role of education and her idea of the world provide a rich source of inspiration for rethinking and tackling the problem outlined. The study is divided into two parts: in the first, I identify the senses in which the imaginary equality has bolstered the emergence of a presentist temporal order, as well as the political contradictions that these energies have engendered. I briefly present how two overarching societal changes - namely environmental changes, as well as transmutations of the capitalist economy - have both contributed to the emergence of a presentist regime of historicity.

Thereafter, I argue that behind this shift, from a future-oriented regime of historicity to a presentist, we should also consider the specific form of equality that I, drawing on Tocqueville, referred to as imaginary equality. Thus, in contrast to the shift from a producer-oriented to a consumeroriented economy and the associated move towards a more financially oriented economy, as well as the increasingly gloomy outlook of the future on account of major climatic changes, I maintain that a politically inspired impulse to further the equalisation of conditions has also contributed to the outlined shift of temporal horizons. Such an impulse is rooted in the ideologically motivated desire to further democratise society by emancipating the individual from the assumed shackles holding her back within the educational sphere. Subsequently, I contrast this form of equality with two, far more common alternatives that appear in political theory: the distinction between formal and real equality.

In light of the political dead-ends that seem to result from the imaginary form of equality as a democratic ideal, in the second part of the study, I explore how Arendt's reflections on the role of the educational system offer an outline of a contrasting fourth political ideal of equality, based on a different temporal logic. As such, I contend that it offers a politically more tenable way of imagining education than the presentist-inducing form of equality that predominates today. Furthermore, I contend that this way of grasping the challenge of education in modern societies calls into question 
the rigid, modern division of traditionalism and progressivism in educational thought.

In virtue of tackling the question of education as a politico-temporal problem with the relationship between world and newcomers as structuring poles, I claim that the analytical categories borrowed from Arendt suggest new, potentially fruitful ways of tackling the question of education beyond reified dichotomies such as traditionalism and progressivism. 


\section{Concluding Discussion}

In this thesis, I set out to examine the ideal of equality in educational policies in the post-war period via what I have called a historico-political approach. Manifested in a number of reforms - such as municipalisation, the introduction of a voucher system, and the virtual explosion in courses for pupils to choose from upper secondary school, as well as the loosening up of rules and regulations regarding the establishment of private schools - the educational system is said to have shifted from being based on a collectivist, equality-promoting order to a liberal, individual-based model of society. Against this backdrop, the aim has been to highlight the transformation of educational policies throughout the post-war period with regard to the idea of equality.

The conclusion that follows contains a furthering of the analyses presented in the articles. Due to the necessarily limited format of journal publications, this longer conclusion is necessary in order to fulfil the overarching objective of thesis. The format of the articles has also forced me to limit my selection of material. As I synthesise my results, I will therefore, to some extent, corroborate my empirical findings from the first two articles with more empirical material. The analysis will proceed in three steps followed by a brief section entitled "Closing Remarks".

The immediately ensuing section, "Educating for Reality", serves to synthesise the results from the articles. To this end, I expound how the concept of presentism interplays with the analytical constructs of the character, the Tocquevillian themes, and the analytical construct of the social. In the second section, entitled "Rupture and Continuity: The Transmutations of Equality", I discuss how the outlined narrative relates to the three initially discerned fields of research by mobilising the analytical framework developed by Jörn Rüsen that I presented in the introductory chapter.

In the third section, under the heading "The Aporia of Equality", I further qualify how the fourth article - namely "Equality and Education: A Historico-Political Approach" - ties in with contemporary political-theoretical discussions regarding a complex of related problems. Thus, whereas the first and the second sections serve to elaborate on primarily the first four research questions, including how they relate to previous research, the 
purpose of the third section is to locate the politico-historical arguments in the second part of the fourth article - the fifth research question - within a broader political-theoretical framework. In terms of the overall aim, this serves to extricate the further implications of my results in relation to the adjacent, more overarching, political-theoretical problems on which my results rest.

\section{Educating for Reality}

In the first article, I approached the policy documents by analysing how the ideal of placing the pupil at the centre of the educational process had changed - and, indeed, how it had stayed the same - throughout the period of the study. ${ }^{98}$ In the second article, I tackled the material in a way that could be seen as a counterpart to the first by examining how the ideal teacher role had changed throughout the same period. ${ }^{99}$ Alongside teachers and pupils, the role ascribed to the transmission of a particular content was another central theme. Due to the close interrelation of these three elements - pupil, teacher, and content - in educational policies, the outcome of the two analyses follow each other closely.

In both articles, I argued that we can witness a dislocation in the ideal of placing the pupil at the centre of the educational process. Initially in the post-war period, the idea was articulated as a more efficient means for achieving the end of having pupils assimilate more knowledge, and thereby becoming better prepared for their future role as citizens. With time, as the first phase of the democratisation had been accomplished, it increasingly became a democratic goal in itself. In line with the explicit aim to further the democratisation of the educational system by also democratising the inner work of the school (in contrast to the major transformation of the multiple educational paths into one common school for all), it appears as if the underlying purpose of the ideal underwent a transformation.

When focusing specifically on the changing role of the teacher during the period, further dimensions emerged, such as the attempts to bring class and subject teachers closer together, as well as limiting the gap between practical and theoretical teachers. ${ }^{100}$ Both tendencies, I maintain, can be related

98 Wedin 2017a.

99 Wedin 2017b.

100 Whereas this ideal, to reduce the gap between the world outside school - the "real" world - by way of integrating the new democratic and comprehensive school, and diminishing the differences between various forms of teachers, appears in virtually all policy documents from 1946 up until 2000, there is a noticeable shift of emphasis within the bills that are actually passed from the first Teacher Training Government Bill of 
to the main aim of furthering the democratisation by reforming the inner life of the school, and, as such, to indirectly prepare the terrain of the reforms around 1990 by negating that which, until the 1970s, had served as a normative counterweight to the individual pupil. ${ }^{101}$ It should be understood as in part the upshot of various attempts to democratise the educational system insofar as the precedent, parallel school system and all that was related to it served as the ideological counter-image - a materialisation of the undemocratic past. More specifically, my claim is that the increasingly negating critique throughout the post-war period served to undermine the basis on which a counter-attack against the successive introduction of a voucher system could have been mobilised, that is, had things developed differently. Due to the triumphant political impulses, which the 1980 s inherited from the radical critique of the 1970s, the window of opportunity for articulating a substantial alternative - a collectively structure idea of education - was closed. ${ }^{102}$ As Gauchet puts it, this can be described as the emergence of an "understanding of collective life based on the abstract individual $[\ldots]$ ", and of man as an essentially unmediated abstract bearer of rights. ${ }^{103}$

1954:209, to the acme of the attempts, materialised in the Government Bill of 1999/ 2000: 135 .

${ }_{101}$ As I argue in the first study, the attempt to reactivate the ideal of Bildung in the report that prepares the new curriculum of 1994 is a noteworthy anomaly in this context. However, as shown in the second study, and as Donald Broady has noted too (and, indeed, as I have argued elsewhere), the re-emergence of the concept of Bildung in educational documents does not seem to indicate a more substantial tendency in policy documents, see: Donald Broady, "Bildningstankens krumbukter. Några blad ur historien från 1970-tal till 2010-tal”, in Anders Burman \& Per Sundgren (eds.), Svenska bildningstraditioner (Göteborg: Daidalos, 2012); Wedin 2017a; Tomas Wedin, "Ideological Continuity and Discursive Changes in the Swedish Educational System", LIR-journal 3.13 (2013): 49-65; Wedin 2015.

102 And that, by implication, the tendency of "reactive" educational policies, without any clear visions for the future that Lundgren argues emerged in the 1990s, was, by that time, firmly established on a discursive level in policy documents. See: Ulf P. Lundgren, "Utbildningspolitik och utbildningskoder: Förändringar i svensk utbildningspolitik", in Jesper E. Larsen, Börge Riis Larsen, \& Susanne Wiborg (eds.), Arbog 2006: Velfaerdsstaten under pres (Köpenhamn: Selskabet for skole- og uddannelsehistorie, 2006), $58 \mathrm{f}$.

103 "n'est autre chose que la lecture de la vie collective pratique à partir de l'individu abstrait [...]", Gauchet 2017, 550; 558. The critique, however, is essentially a furtherring of Marx's critique in Zur Judenfrage. See: Karl Marx \& Friedrich Engels, Werke Band 1 (Berlin: Dietz, 1981). Therefore, as much as I agree with the argumenttation in Jenny Andersson's otherwise excellent study on the rupture and continuity within Social Democracy and New Labour during the 1990s, where she argues that their loss of utopian energies has contributed to the manifest changes in the 1990s, I contend that the dynamics outlined here serve to complete her analysis. Thus, when she writes that it seems as if Social Democracy does not have any "real answer to the question of what opportunity and human potential are, or what defines the common good in an era where individuals may be increasingly concerned with the cultivation of their selves but also 
In contradistinction to earlier societies, which were seen to be structured around some shared normative ideals or shared norms, democratic society has tended to progressively undermine forms of constructively uniting structures alongside the pervasive, equality-promoting, rights-based order. As the French anthropologist Louis Dumont writes, earlier societies have been integrated "with reference to values" that transcend the individual in virtue of representing something fundamentally other. ${ }^{104}$ Moreover, as Tocqueville notes, this equality-driven form of individualism, by annihilating all forms of alterity, also undercuts the political forms that undergird our own individual independence. ${ }^{105}$ This criticism is an important point of convergence between the form of republicanism cherished by Hannah Arendt, the more Durkheimian approach of Gauchet, and Tocqueville's reflections on the burgeoning modern society, despite their differences in other respects.

It would, however, be a misunderstanding to assume that all differences will vanish: equality can surely be merged with the "recognition of differrences, on the condition that these differences are morally neutral". ${ }^{106}$ This is where, as I argue in the third study, the impulses identified here tie in with Michel Foucault's analyses of a new governmentality. More specifically, I argued that the explicit exhortations to have an entrepreneurial logic pervade the whole educational system, alongside the interpellation of pupils and their parents as homines oeconomici right from the outset when choosing a school, should be understood in light of the tendencies explored here. ${ }^{107}$ Whereas pre-modern societies have been built on an assumed transcendent hierarchy of values, to which the ruling classes have stood in a particular and beneficial relationship, modern capitalist societies have tended - with a

seem to ask for new forms of belonging”, I maintain that my results provide a relevant clue to our attempts to understand why this is so. See: Jenny Andersson, The Library and the Workshop: Social Democracy and Capitalism in the Knowledge Age (Stanford: Stanford University Press, 2008), 156.

104 "par référence aux valeurs", Louis Dumont, Homo hierarchicus (Paris: Gallimard, 1992), 318.

105 Cf. study 3. Luc Boltanski is, therefore, wrong when arguing that the "new critique" that emerged in the wake of May ' 68 is "if not non-egalitarian, at least only weakly orientated towards the aim of equality"; and the Tocqueville-inspired idea of an imaginary form equality is essential for understanding why. See: Luc Boltanski, "The Left After May 1968 and the Longing for Total Revolution”, Thesis Eleven 69.1 (2002): 7.

106 "reconnaissance de différences, à la condition que ces différences soient moralement neutres", Dumont 1992, 322.

107 Michel Foucault, Sécurité, territoire, population (Paris: Gallimard, 2004), 111f.; Michel Foucault, Naissance de la biopolitique (Paris: Gallimard, 2004), 232. I refer here to idea of homo economicus in the extended sense as developed by Gary Becker and others in the Chicago School, as well as the idea of human capital from the 1960s onwards, see: Becker 1992. A similar point is made by John Milbank and Adrian Pabst in The Politics of Virtue. 
conspicuous acceleration in the post-war period - towards the morally egalitarian logic of welfare-maximisation and negative freedom. ${ }^{108}$ And this, I should add, is perfectly compatible with a wide range of positive rights - but not a substantial ideal of freedom, which inevitably, as I have attempted to show, is concomitant with some form of hierarchies. "The coils of a serpent", as Gilles Deleuze remarks, are indeed "more complex than the burrows of a molehill”. ${ }^{109}$

Aside from the dynamics outlined in the empirical articles, it is illuminating to compare my findings in relation to how the role of cultural heritage has been discussed in various curricula for the comprehensive school throughout the period. In formulations comparable to those quoted in the studies, the curricula of 1962 and 1969 both state that the school carries an important responsibility in protecting that which is, to quote the curriculum for the mandatory school of 1969, "valuable from the past". ${ }^{110}$ In 1962, the claim is made more directly: as a "societal institution it [the school] has to a large degree the task to manage and transmit the cultural heritage". ${ }^{111}$ Along the lines of the tendencies outlined in the two articles, the curriculum of 1980 contains no such formulations. The closest sentiment we find there is that education, in adapting to the interests of the particular pupils in each school and class - whilst having the content concretised in the present ought to take the past as its starting point. ${ }^{112}$

Interestingly, and in line with the demand to adapt to the specific needs of particularities, there is one form of cultural heritage that is essential to defend in school, namely the heritage of pupils whose mother tongue is not Swedish. ${ }^{113}$ In a similar vein, but now explicitly framed with reference to the ongoing "internationalisation of Swedish society" and the importance of emphasising the value of living in a culturally diverse society, the curriculum of 1994 states that an "awareness of one's own and participation in the shared cultural heritage gives an assured identity". ${ }^{114}$ In terms of how cul-

${ }_{108}$ As Amartya Sen puts it: "Welfarism asserts that the goodness of states of affairs depends ultimately only on the personal utilities in the respective states [...]", see: Amartya Sen, "Utilitarianism and Welfarism", The Journal of Philosophy 76.9 (1979): 487.

109 "Les anneaux d'un serpent [...] plus compliqués que les trous d'une taupinière", Gilles Deleuze, "Post-scriptum sur les sociétés de contrôle", L'autre journal 1 (1999).

110 “det värdefulla från gången tid”, Läroplan för grundskolan 1969, 11.

111 "som samhällsinstitution har den i hög grad uppgiften att förvalta kulturarvet och föra det vidare”, Läroplan för grundskolan 1962, 14.

112 Läroplan för grundskolan 1980, 17. See also: Larsson 2002, 109.

113 Läroplan för grundskolan 1980, 16.

114 "medvetenhet om det egna och delaktighet i det gemensamma kulturarvet ger en trygg identitet", Läroplan för det obligatoriska skolväsendet 1994, 5. The same formulation is 
tural heritage is framed here, culture seems to be understood along the lines of ethnicity and religious belonging, echoing the debates on multiculturalism that emerged in the early 1990s. Nevertheless, it should be stressed that the dynamics indicated by my results go further back in time and, as such, are not conditioned by the future debates around multiculturalism in the 1990s, and the much-discussed shift from class struggle to struggles for recognition. ${ }^{115}$ Therefore, although the very discussion regarding recognition is related to the question of multiculturalism and the societal changes in late modern Western societies, it would, tentatively, seem as if the outlined individual-centred tendency of equality anticipates the demands for recognition that would explode in the 1990s. ${ }^{116}$ Judging from how the question of equality was discussed in other reports from the 1990s, in respect of the educational system and the role of youths in society, as well as how it has been discussed in existing research, the general tendency seems to be a strengthening of the here outlined impulses. ${ }^{117}$ However, the question of whether this could actually be confirmed empirically is beyond the scope of this thesis.

With regard to the noted changes in the role of culture as a structuring ideal in educational policies, there are some noteworthy points of convergence in terms of how the concept of culture per se was envisioned during the period. ${ }^{118}$ Whereas culture as an explicitly defined sphere of politics was non-existent in the $1950 \mathrm{~s}$, it became a major topical theme in the $1960 \mathrm{~s} .{ }^{119}$

repeated in the curriculum of 2011 as well, see: Läroplan for grundskolan, förskoleklassen fritidshemmet 2011, 7 .

${ }^{115}$ For an analysis of how the emergence of recognition could be understood in relation to the previously dominant demands for redistribution, see: Fraser 1996.

116 As exemplified on a policy level by e.g. the following three reports: SOU 1996:143; SOU 1997:121; SOU 2006:40.

117 As mentioned, a wide array of studies has been written on the theme of multiculturalism in Swedish educational policies, see e.g.: Nykänen 2009; Rosenquist 2011.

118 In the ensuing discussion, I will not explicate the various definitions of culture discernible in the debate, nor will I give an account of the traditions to which they belong. Instead, my discussion is instrumental and serves merely to shed further light on the chief problem. For insightful overviews of the concept, see: Raymond Williams, "Culture", in Keywords: A Vocabulary of Culture and Society (London: Fontana, 1988); Terry Eagleton, The Idea of Culture (Oxford: Blackwell, 2000); Johan Fornäs, Defending Culture: Conceptual Foundations and Contemporary Debate (London: Palgrave Macmillan, 2017); Hannah Arendt, "Crisis in Culture", in Between Past and Future (London: Penguin, 2006a).

119 It was not, however, until 1974 that Sweden would get its first official cultural politics with the Government bill on cultural politics, Government bill 1974:28. As in the case of the educational policies, the 1960 s was marked by increasingly radicalised critiques of the hitherto qualitative, hierarchical concept of culture, corresponding to the tendencies outlined in the educational policies from the late 1960s, and even more so in the $1970 \mathrm{~s}$ and 1980s. Concerning the debates regarding cultural policies in Sweden, see: Anders 
Prompted by the publishing of the book The Democratic Vision of Culture (Demokratins kultursyn) by the author and journalist Bengt Nerman, discussions about the meaning of culture were intensified, as the purportedly "bourgeois" and/or "conservative" concept of culture came under fire. ${ }^{120}$

A number of the critics challenged the qualitative distinctions on which the default "bourgeois" concept of culture rested. They criticised it for being both paternalistic and rooted in an unequal vision of societal phenomena, favouring expressions that reflected bourgeois experiences. ${ }^{121}$ Interestingly, the ways in which Nerman defines a democratic approach to culture in the concluding chapter of his seminal work bear a striking resemblance to the key ideas in educational policies. In contrast to the conventional definition, where culture is something "given, something static", Nerman advocates a more anthropological definition of culture, wherein it "becomes a word for each individual's activity of expression and for the results of this activity". ${ }^{122}$ "As a principle", he continues,

it leaves man being in the world, not as a result of something or a potentiality to something but as a reality, dependent on and changing itself with each other change, free to be simple, close to the relative, not bound up with the ideal. ${ }^{123}$

This democratic vision of culture should be contrasted with the

$[\mathrm{m}]$ oralistic vision of culture, which is hardly democratic but yet the norm in our democracy, comes from the outside and wants to change man in a particular direction, making him not just different, but aspiring to something more. ${ }^{124}$

Frenander, Debattens vågor: Om politisk-ideologiska i efterkrigstidens svenska kulturdebatt (Göteborg: Göteborgs universitet, 1998); Anders Frenander, Kulturen som kulturpolitikens stora problem: Diskussionen om svensk kulturpolitik under 1900-talet (Hedemora: Gidlunds Förlag, 2005); My Klockar Linder, Kulturpolitik: Formeringen av en modern kategori (Uppsala: Uppsala universitet, 2014); My Klockar Linder, När kultur var i rörelse: Kulturbegreppets förändring under sextiotalet, speglad genom tidskriften OrdङBild (unpublished Master's thesis, Södertörn, 2006); Per Sundgren, Arbetarrörelsen och kulturen: Kultur politiska strävanden från August Palm till Tage Erlander (Stockholm: Carlsson Förlag, 2007); Per Sundgren, Smakfostran - en attityd i folkbildning och kulturliv (unpublished paper, 2001).

120 Frenander 2005.

121 Frenander 2005, 133ff.

122 "givet, något statiskt"; "blir ett ord för varje individs uttrycksaktivitet och för resultaten av denna aktivitet", Bengt Nerman, Demokratins kultursyn (Stockholm: Albert Bonniers Förlag, 1962), 91; 92 .

123 “den låter i princip människan vara i världen, inte som resultat av något eller möjlighet till något utan som realitet, beroende av, förändrande sig med varje annan förändring, fri att vara vanlig, enkel, närvarande i det relativa, inte inspänd i det ideala”, Nerman 1962, 92. 
What makes the debate regarding the definition of culture from the $1960 \mathrm{~s}$ onwards so compelling for the present discussion is not that such a critique conjoins with the tendencies outlined in the educational policies - similar expressions can presumably be found in a number of other societal spheres from this period. Rather, what makes it interesting is the conspicuous difference in terms of policy outcomes when compared with the educational sphere.

By and large, the Government bill that eventually arrived in 1974, despite including some formulations drawing on the critique of the 1960 s, is generally thought of as a manifestation of a relatively untouched conception of culture, that is, one that maintained important strands of the "bourgeois", hierarchical ideal. And in the wake of the bill of 1974, not much happened either from the 1970s until 2000. ${ }^{125}$ As the intellectual historian Anders Frenander rightly observes, this is somewhat surprising, given that society at large has undergone a number of manifest changes within the same period. ${ }^{126}$

With all due reservations, both for the differences of the present study and those studies regarding cultural policies, one can tentatively suggest that those who struggled for a substantial redefinition of culture were not at all as unsuccessful as the outcomes in cultural policies would indicate. Indeed, it was not the limited sphere of cultural policies that was deemed to be the spearhead into the future; it was the education system. This was

124 "Den moraliserande kultursynen, som ju är mycket litet demokratisk men ändå den normala I vår demokrati, kommer utifrån och uppifrån och vill förändra människan i en viss riktning, göra henne inte bara annorlunda, utan till något mera”, Nerman 1962, 92. However, the most radically individualist and relativist position was taken by young liberals who wanted to erase all forms of value judgements and qualitative distinctions. See: Sundgren 2001, 74.

${ }^{125}$ Frenander suggests three possible reasons for this: (i) cultural politics has never played an important role in Sweden; (ii) the ideological underpinnings of the Social Democrats that had dominated society remain active in cultural policies; and (iii) the complexities of establishing hegemony along the lines of the previous idea of Folkhemmet (as Frenander points out, it is an open question in terms of how much this category can be separated from the first two mentioned). See: Frenander 2005, $212 \mathrm{f}$.

126 In contrast to Per Sundgren (in Sundgren 2001), as another intellectual historian who has analysed the role of culture in the post-war period, who posits that this is a manifestation of a lagging conservatism within an overall progressive labour movement, I want to stress how the shift towards the individual also has bearing on how we orient in time. The relevant sense in which the very defence of qualitative differences is related to the future is that, in lieu of qualitative differences, we will have a harder time in seeing the point in working for a substantial change for the better - not in accordance with some preordained ideal, some reified utopia to which we ought to surrender ourselves, but simply by virtue of the conviction that there are better and worse ways of organising collective life, beyond that which happens to enhance the utility-function of individuals. 
where the action was, so to speak, and where central tenets in Nerman's critique would be substantiated, albeit without, it would seem, the long-term benefits for democracy as a political way of life that its promoters from the left had envisaged.

In the next section, we will turn to the various concepts that I have gathered throughout the studies, and see how they tie in with each other, as well as exploring how we could further elaborate on them and why, ultimately, the outlined strands of continuity are historically and politically pertinent.

\section{Presentism and the Late Modern Teacher as a Character}

In Hartog's reflections on the expansion of the present at the expense of both the past and the future, the arguments unfold at a high level of abstraction. In employing the analytical category of regimes of historicity, Hartog reflects on the transmutations of how cultural spheres and civilisations have deployed themselves in time throughout history.127 In my analysis, the abstraction is brought down to the level of educational policies, where I argue that it renders more comprehensible key aspects of the shifts during the post-war period. Through his analytical construct, I have been able to discern the politico-temporal continuity between the 1970s and the 1990 s.

What Hartog calls the presentist regime of historicity could be compared with what the German sociologist Hartmut Rosa refers to as an acceleration of time. ${ }^{128}$ This way of envisioning the phenomenon has the advantage of more clearly stressing the continuity between the forward-oriented regime of historicity typical of the modern period, and the presentist regime typical of late modernity: from Marx and Engels's apposite formulations from 1848

127 Hartog 2012.

128 In the same vein, the German philosopher Hermann Lübbe has developed the term $G \boldsymbol{e}$ genwartsschrumpfung, arguing that what I refer to as the emergence of a regime of presentism could be understood as a contraction of the present. Closely coinciding with what I have called the expansion of a presentist regime of historicity, Lübbe's definition has the advantage of illustrating how the constriction of both past and future as structuring horizons could be thought of as a contraction of the present itself, as our experience of the present stands in a positive relationship to both the past and the future. See: Herman Lübbe, "The Contraction of the Present", in Hartmut Rosa \& William E. Scheuerman (eds.), High-Speed Society: Social Acceleration, Power and Modernity (Pennsylvania: Penn State University Press, 2009); Hermann Lübbe, Im Zug der Zeit: Verkürzter Aufenthalt in der Gegenwart (Berlin: Springer, 1992); Hartmut Rosa, "Social Acceleration: Ethical and Political Consequences of a Desynchronized High-speed Society", in Hartmut Rosa \& William E. Scheuerman (eds.), High-Speed Society: Social Acceleration, Power and Modernity (Pennsylvania: Penn State University Press, 2009); see also: Paul Virilio, Vitésse et politique (Paris: Édition Galilée, 1977). 
through to the Futurists of the early twentieth century up to the increasing focus on the present from the 1970 and onwards.

In this sense, contemporary society, as many have pointed out, rather than being indicative of a postmodern condition, appears more like an intensified, or "accelerated", condition of hypermodernity. ${ }^{129}$ And as indicated in the article on Tocqueville, the same goes for the question of equality. ${ }^{130}$ Therefore, although the presentist tendencies in educational policy documents indicate that an important shift has occurred in the post-war period, it is crucial to also keep in mind that the shifts can be traced back to distinctly modern energies. What I have referred to as the expansion of a presentist regime of historicity, after Hartog, could in this sense be thought of as the emergence of a new temporal modus of politics, conveying a shift of emphasis towards the individual at the expense of institutions, here represented by the school. With regard to Hartog's focus on the emerging experience of a condition of crisis - economic crisis, climatic crisis, etc. - my results draw out the continuity before and after the perceived experience of crisis emerged, as I emphasise the ideological impulses behind the varying nuances. ${ }^{131}$

That said, it remains an open question as to how the results tie in, more precisely, with the emerging experience of living in times of crises, for which the 1970s could be considered an approximate watershed, with the oil crises of 1973 and 1979 and the collapse of Bretton Woods in 1971, as well

129 See e.g. Rosa 2009; Hartmut Rosa, Social Acceleration: A New Theory of Modernity (New York: Columbia University Press, 2013); Jameson 1992; Gauchet 2017; Lübbe 2009. One aspect of these changes, which I will not discuss further, is how these can be related to the emergence of a new, more detached, memory culture. As the key reference within the field, Pierre Nora, puts it: "There are lieux de mémoire, sites of memory, because there are no longer milieux de mémoire, real environments of memory". See: Pierre Nora, "Between Memory and History: Les Lieux de Mémoire”, Representations 26 (1989): 7. His major work on the topic is the three-volume work Lieux de mémoires. See: Pierre Nora, Lieux des mémoires: La République; La Nation; Les France (Paris: Gallimard, 1984; 1986; 1992).

${ }^{130}$ In order to further emphasise the continuity between the modern and our late modern regime, consider, alongside the already invoked examples of Tocqueville and Marx and Engels, how the paradox is expressed in Twilight of the Idols: "The West in its entirety has lost the sort of instincts that give rise to institutions, that give rise to a future: it might well be that nothing rubs its 'modern spirit' the wrong way more than this $[\ldots]$ The things that make an institution into an institution are despised, hated, rejected [...]". See: Friedrich Nietzsche, "Twilight of the Idols", in Aaron Ridley \& Judith Norman (eds.), The Anti-Christ, Ecce Homo, Twilight of the Idols, and Other Writings (Cambridge: Cambridge University Press, 2005), $214 \mathrm{f}$.

131 It should be noted that Hartog does not neglect the continuity between the forwardoriented regime and the presentist, and he explains how presentist tendencies are already evident in e.g. Marinetti's Futurist Manifesto and Roquetin's position in Sartre's La nausée. See: Hartog 2012, 149ff. 
as a growing awareness of the deteriorating environment. Although these questions fall outside the scope of this thesis, I sketch the outlines of how such a discussion could be advanced with respect to the economic changes in Excursus II.

In the wake of Hartog's notion of the emergence of a presentist regime of historicity, a strand of critique has taken shape focusing on what is seen to be a simplification of our ways of deploying temporally throughout history. Hartog's theory has been criticised for reducing what in fact should be understood as a plethora of synchronous and competing regimes of historicity. For example, a critique of Hartog along these lines has been put forward by the historian Helge Jordheim, who has convincingly argued that it would be wrong to assume that only one regime of historicity exists, and that we must take into account how competing regimes co-exist, with "differing time regimes and different speeds, durations and rhythms". ${ }^{132}$

Jordheim suggests an essential qualification of Hartog's analysis. At the same time, as Rosa has noted, it should also be stressed that not all temporalities have an equal impact. That is to say, we must evaluate how the "simultaneously non-synchronic" temporalities relate to each other, and in particular to what degree some of them might be comprehended as reactions to or results of other ones. ${ }^{133}$ The shift of emphasis towards the present at the expense of both the past and the future within the educational system does not appear to be on a par with the increased popularity of slow-food, for example, in contemporary society. In other words, it is reasonable to assume that the noted shifts in the educational system indicate an impulse that, in virtue of playing such a fundamental role in modern society, carries significant weight - much more so than the ever-increasing popularity of "old things" on a more general basis in society.

It is against this backdrop that my usage of the MacIntyrean character should be understood, as the teacher ideal that grew out of these transmutations in the post-war period appeared increasingly empty and outdated. As I have argued throughout the thesis, it is vital to comprehend this metamorphosis as also the upshot of the radicalised progressivist ideal to emancipate the individual. Rather than stressing the role of school as an institution for introducing the pupils to the public sphere, with the formal roles and personae of which this sphere ideally is constituted, teachers were increasingly called on to address pupils in what I, after Zijderfeld, have

\footnotetext{
132 "skilda tidsregimer och skilda hastigheter, varaktigheter och rytmer", Helge Jordheim, "Historiemedvetande, tidsregimer och synkronisering", in Victoria Fareld \& Hans Ruin (eds.), Historiens hemvist 1: Den historiska tidens former (Stockholm: Makadam Förlag, 2016), 187.

133 Rosa 2009, $91 \mathrm{f}$.
} 
referred to as their subjective identity. ${ }^{134}$ Moreover, as I point out in all four of the articles, this is a tendency that, alongside the structural changes, could be read as the outcome of the radicalisation of the impulse that I have described with reference to an imaginary equality and the expansion of what Arendt terms "the social". ${ }^{135}$ In doing so, it also fomented the illusion that each and every one of us is the sovereign ruler over herself. ${ }^{136}$ However, where Tocqueville warned of the consequences of what he saw as an emerging societal shift, what I referred to as democratic epistemology (the first theme), I have contended that this was elevated to a decree in the postwar period.

Moreover, in addition to the ideological convictions, we also find a number of parallel and interacting practical needs that coincide with the desideratum of democratising the educational system. Following in the footsteps of previous research, I have stressed how, as a consequence of the implementation of the comprehensive school, the constant feature of resource constraints was felt even stronger and played a non-negligible role in, for example, the demands to bring class and subject teachers closer together. Thus, the endeavour to eradicate the continuing existence of the parallel school division within the framework of the comprehensive school, as well as the re-articulation of the ideal teacher that is discernible in the policy documents, must also be understood as effects of economic constraints.

Furthermore, alongside the imaginary form of equality and the practical motives, the reforms of the educational system must be considered in light of the attempt to adapt the school to the vicissitudes of the global labour market and the concomitant technical advances - the so-called "third industrial revolution" - that has successively restructured society since the 1970s. In the empirical analyses, I demonstrate how this materialised in policy documents in the form of calls to decrease the gap between society and school. Another expression of this was the increased emphasis on the means to learn - that is, learning how to learn - rather than the assimilation of content. ${ }^{137}$ In other words, the importance of transmitting specific content

${ }^{134}$ Zijderveld 2000, p. 13. Essentially, this definition is identical to Gauchet's concrete individualism, and they are both in turn inspired by Émile Durkheim, see: Émile Durkheim, Sociologie et philosophie (Paris: PUF, 2014), 1-39.

135 I expand on this idea in my discussion of the concept of the social.

136 Arendt discusses this in: Arendt 2006a, "What is Freedom". See also: George Kateb, "Political Action: Its Nature and Advantages", in Dana Villa (ed.), The Cambridge Companion to Hannah Arendt (Cambridge: Cambridge University Press, 2002); George Kateb, Hannah Arendt (Oxford: Rowman \& Allanheld, 1983).

137 Wedin 2017b. 
was downplayed with reference to the ever-accelerating technical development, and a greater emphasis on the learning techniques was called for. This is an elucidating example of how the demands of the economy and the proclaimed attempts to democratise the educational system coincided, according to a logic where the unpredictability of the future becomes a force that binds us to the temporal confines of the present, focusing on the forms of learning, to master the techniques. ${ }^{138}$ As indicated, the relationship between the structural economic conditions and the overarching narrative of this thesis will be further elaborated upon in Excursus II.

The demand to reduce the gap between school and society is a recurrent idea throughout the post-war period, and it has sometimes been proposed with particular fervour. ${ }^{139}$ As exhibited in terms such as "entrepreneurial learning", employability, and flexibility, it was also a pivotal theme of the last wave of reforms (2008-2011). However, where the arguments mobilised between 1970 and 2000, as shown, were ambiguous (even ostensibly paradoxical), the educational ideals articulated in the last cycle of reforms, as shown in previous research, appear to be more unequivocally related to the country's competitiveness, i.e. to be subjected to the demands of the labour market. ${ }^{140}$

\section{The Social and the Role of Institutions}

When I mobilised the social as an analytical tool, it was activated on an operational level to ascertain how the outlined tendencies could be understood from an institutional perspective. ${ }^{141}$ In consequence, as the realisation

${ }^{138}$ In a recent interview with the previous director-general of the Swedish National Agency for Education, Ulf P. Lundgren, he describes the emergence of "competences" as educational goals along the same lines. See: Piero Colla \& Tomas Wedin, "De la planification à la liberté de choix: Une révolution pour le modèle éducatif suédois? Conversation avec Ulf P. Lundgren", Nordiques (forthcoming).

139 As the intellectual historian Thomas Karlsohn observes, it was e.g. also a crucial theme in the argumentation of those advocating an all-encompassing computerisation of the school, see: Karlsohn 2009.

${ }^{140}$ Sara Carlbaum, Blir du lönsam lille vän (Umeå: Umeå universitet, 2012); Magnus Dahlstedt \& Fredrik Hertzberg, "Den entreprenörskapande skolan: Styrning, subjektsskapande och entreprenörskapspedagogik”, Pedagogisk forskning $i$ Sverige 16.3 (2011); Eva Leffler, Företagsamma elever: Diskurser kring entreprenörskap och företagsamhet $i$ skolan (Umeå: Umeå universitet, 2006). For an overview of how the ideology of labour-market adaptation has been articulated throughout the post-war period, see: Wedin 2013.

${ }_{141}$ Wedin 2017b, 236. It is worth stressing again the ambiguous status of the educational sphere, in virtue of being a peculiar space "in-between" the private and the public. I do, however, maintain that the proper political attitude towards education is to evaluate it with the right public attitude, that is, by having the world at the forefront of our minds when discussing it. For Arendt's uses of the concept and how I respond to the critique 
of the comprehensive school had been implemented (which was not realised until the early 1970s), and the democratisation of the educational system entered into its second phase, with its insistence on centring the here-andnow and to have teachers further accommodate pupils' diverse experiences, a gradual turn took place. In this turn, care for the public space progressively gave way to an emotional logic that I have argued attitudinally stems from the private sphere. I have maintained how the social as an analytical construct can enhance our understanding of this move by eliciting how political impulses of various shades contributed to considerations that were hitherto subsumed under the private sphere being transposed into the educational sphere. Furthermore, as developed in studies three and four, this shift was fomented by a form of imaginary equality. Within this transformation, Tocqueville's remarks on what I termed democratic epistemology coincide with his claim that natural bonds will tend to replace social bonds.

A wide array of tendencies in educational policies throughout the period betokens this: attempts to include more of pupils' private experiences within the school; efforts to bring closer class and subject teachers, and to reduce the gap between practical and theoretical teachers. All of these features, to varying degrees, can be related to the imaginary form of equality. In addition, they can all be related to practices and attitudes that, in institutional terms, correspond to the private sphere, where the individual is addressed in her particularity.

Clearly, the protection of the private sphere is essential, and it goes without saying that anyone working professionally with humans cannot, and should not, leave her psychological sensibility at home when leaving for work. However, as I argue in the fourth article, when she loses her sense of distinction between public and private personas, she risks both spheres. ${ }^{142}$ As Arendt writes:

The more completely modern society discards the distinction between what is private and what is public, between what can thrive only in concealment and what needs to be shown to all in the full light of the public world, the more, that is, it introduces between the private and the public a social sphere [...], the harder it

levelled against her usage of the concept, see the reflection on using the social as an analytical category.

142 As Arendt also remarks on numerous occasions: see Arendt 1998: 38ff. An illuminating contemporary example of this can be seen in how people, when discussing politics, culture, etc., appear increasingly prone to feel rather than to think or form a well-grounded position in ongoing public debates. 


\section{CONCLUDING Discussion}

makes for its children, who by nature require the security of concealment in order to mature undisturbed. ${ }^{143}$

Maintaining a clear distinction between the two spheres therefore serves to protect not just the world, but also the pupil qua child. Advising teachers to primarily address pupils as precisely pupils, thereby inviting them to an order structured by a public emotional logic, could also be thought of as a strategy for letting the children be children when not pupils. Put differently, to introduce them to a role-ordered world could also be seen as a strategy for defending their specificity as individualised children, and to teach them how to harbour both and keep them separated. ${ }^{144}$

An analogous tendency within the welfare sector has been noted by the political scientist Helena Stensöta in her thesis The Empathic State (Den empatiska staten). ${ }^{145}$ As hinted at by the title, the results of her study point in the same direction as the impulse that I have analysed here. Along the lines of my argument in "The Democratic Paradox", Stensöta shows how there is a clear ideological continuity in respect of how the relationship between children and adults was envisioned in key policy documents from the late 1960s up to the 1990s, culminating in Government bill 1995/96:206, in which the Social Democratic government, under Göran Persson as Prime Minister, called for a further integration of preschool pedagogics also in school. ${ }^{146}$ Alluding to the relatively new idea of life-long learning, the government argued that it is essential that school adapts to the preschool tradition, characterised by "the single child, free play and creation", all practices regarded as fundamental to guaranteeing the potential for all children to succeed in school. ${ }^{147}$ In what is by now a familiar fashion, preschool is

143 Arendt 2006a, 185. Similar arguments have more recently been put forward by the German sociologist Thomas Ziehe and the Swedish ethnologist Jonas Frykman. See: Thomas Ziehe, Kulturanalyser: Ungdom, utbildning och modernitet (Stockholm/Stehag: Symposium Bokförlag, 1989); Jonas Frykman, Ljusnande framtid (Lund: Historiska media, 2014).

144 Tomas Wedin, "Education and Emotions: From One Emotional Logic to Another", Conference Proceedings. The Future of Education (Florence: Libreria universitaria, 2018). See also Karlsohn's reflection on emotions and education, to which I am heavily indebted: Thomas Karlsohn, “On Emotions, Knowledge and Educational Institutions”, Confero 4.1 (2016): 137-164. The distinction could be compared to the dangers of sentimentalism that Arendt highlights in: Arendt 2006b; as well as Hannah Arendt, Crises of the Republic (San Diego/New York/London: Harcourt Brace \& Company, 1972), 161.

145 Stensöta 2004.

${ }_{146}$ Wedin 2017b; Stensöta 2004, 96. See also: Helena Stensöta, "Den empatiska staten”, Ord Eं Bild 3-4 (2006): 46-55.

147 "det enskilda barnet, den fria leken och det fria skapandet", Government bill 1995/ 96:206, Vissa skolfrågor m.m., $16 f$. 
thereafter contrasted with the school tradition, where the focus is on the "group and the class, taking the subject as its point of departure and stressing the cognitive". ${ }^{148}$

Then again, it should be stressed how Arendt, rightly in my view, distinguishes between the action of the public sphere and the preparatory work that occurs within schools. Whereas the public sphere functions as both an arena for each citizen to disclose their particular who, short of which the world would cease to exist, and a way for citizens as a collective to undergird what Arendt calls a world, the school serves to introduce the newcomers to this world. ${ }^{149}$ As such, it does not form part of the public sphere; rather, it is intended to bridge the private and the public. Thus, when the pupil enters school and is addressed qua pupil, it is something quintessentially different from an adult individual partaking in public affairs, as a citizen among peers. Reality for us as private beings is one thing; as participants of a political community it is something quite different. One of the main aims of the educational system, therefore, I contend, should be to introduce us to the distinction between the public and private spheres, as well as to acquaint pupils with the public sphere - and thereby simultaneously, as I argue in study four, stimulate the public sphere, which, to a large degree, is underpinned precisely by institutions like the school. ${ }^{150}$

\section{On the possibilities and limits of the social as an analytical tool}

In light of the controversies provoked by the use of the social as an analytical concept, it is worth addressing some of the critiques that have been levelled against it, before proceeding to the main discussion. This is

148 Government bill 1995/96:206, 16ff (pagination is not clear, and I therefore refer to the pages following the relevant section).

149 The disclosure of the "who" is contrasted with the "what", with which Arendt refers to the multiple traits - qualities, gifts, talents, etc. - that we share with other individuals, see: Arendt 1998, 179ff. As such, it overlaps with Paul Ricoeur's distinction between ipse and idem in his reflections on identity; whereas the ipseity of a person is the specific way in which she is she, the non-utterable ways in which I differ from all else (thereby overlapping with Arendt's "who"), the idem refers to those dimensions of my identity that are shared with others. See: Paul Ricoeur, Soi-même comme un autre (Paris: Points, 2015), $11 \mathrm{ff}$. Emphasising the importance of maintaining the world as something intersubjectively shared could also be thought of as a strategy for countering the tendencies of man in modern society to retract into "the darkness of the heart". For a discussion on this theme in Arendt's thought, see: Dan Degerman, "Within the Heart's Darkness: The Role of Emotions in Arendt's Political Thought", European Journal of Political Theory (2016): 1-21.

${ }_{150}$ Wedin 2018b. On the role of institutions in Arendt's thought, see also: Ingrid Straume, "A Common World? Arendt, Castoriadis and Political Creation", European Journal of Social Theory 15.3 (2012): 367-383. 
also an opportune moment for me to explain why I maintain that the social remains nevertheless an important analytical tool for understanding the central problem of this thesis. In the following, I will therefore refine my use of the concept in dialogue with Seyla Benhabib. In her illuminating discussion - and critique of - Arendt's political thought, Benhabib distinguishes between three ways of interpreting Arendt's much contested and, for some, infamous usage of the social. ${ }^{151}$ Drawing on her analysis of the concept, I will discuss its limitations as well as its unique analytical advantages.

We must, Benhabib contends, distinguish between the social as: (i) a given content, or object of discussion; (ii) an attitudinal category; and (iii) an institutional distinction. According to the first definition, which is perhaps the most common interpretation, and the one that has provoked most outrage in the reception, an example of the social is when economic distribution is discussed in the public sphere. There are, by implication, issues that, due to their ontological qualities, define them as either social or political.

Due to the rather inflexible way of thinking of the concept that this approach confirms, I side with Benhabib's critique, as I have difficulty in seeing how the social can help us to better understand the world. As Arendt puts it, the crucial question regarding the usefulness of an analytical construct should be: "can you point to something very real with these words", i.e. do they "have a revealing - or disclosing - quality" or do they not? ${ }^{152}$ Clearly, defined in such a reified way, as a given content, the concept appears of little use. It seems, rather, as Benhabib succinctly puts it, to erect

${ }^{151}$ Hanna Fenichel Pitkin's analysis is probably the hitherto most comprehensive study of the concept. However, for the purpose of the present thesis, Benhabib's distinctions have proven more fecund. See: Hanna Fenichel Pitkin, The Attack of the Blob: Hannah Arendt's Concept of the Social (Chicago: University of Chicago Press, 1998). For an example of how provocative it seemed to some of her colleagues, see: Hannah Arendt, Hannah Arendt: The Recovery of the Public World, edited by Melvyn A. Hill (New York: St. Martins Press, 1979), 301ff. For another defence of the social in Arendt's thought and how it ties in with her concept of the world, see: Dana Villa, Public Freedom (Princeton: Princeton University Press, 2008). However, as mentioned in the second study, her usage of the concept is incoherent: Arendt's application of the concept to the specific case of segregated schools in Little Rock, Arkansas, in 1957 is incompatible with what she writes elsewhere, in e.g. "Crisis in Education" and The Human Condition. But, as pointed out, her conclusions in "Little Rock" will be left out of this thesis, as my engagement with her political thought is primarily of a practical rather than exegetic nature. See: Hannah Arendt, "Reflections on Little Rock", in Responsibility and Judgment (New York: Schocken Books, 2003).

152 Arendt quoted in Hill 1979, 319. 
an "ontological wall" between the social and the political, as if they constituted an absolute either/or dichotomy. ${ }^{153}$

According to the second definition of the social, it is, in Arendt's words, conceived of

as the form in which the fact of mutual dependence for the sake of life and nothing else assumed public significance and where the activities concerned with sheer survival are permitted to appear in public. ${ }^{154}$

Again following Benhabib, I believe that this does seem to be a fruitful way of conceiving of the social: it does indeed, as seen in the second study, seem to have the capacity to disclose phenomena in the world, such as policy discussions and reforms. However, contrary to Benhabib's conditioning of her acceptance, arguing that it seems indebted to "the quasi-aristocratic" distinction between bread and politics, I would maintain the fundamental importance of principles as regulative ideals for political action, and that this - i.e. collective political ideals, or visions - is exactly one of the dimensions that disappeared from the policy documents. ${ }^{155}$ Indeed, as I argue in the fourth article, one of the primary tasks of school is precisely to introduce the child to a public order, via public roles and the personas through which the pupils can learn to distinguish between public and private, based on collective principles that (ideal-typically) differ from the temporal and normative order of the private household.156 In attempting to adapt school to the plethora of experiences that pupils come with, our long-term possibilities of jointly charging responsibility for the public sphere have been gradually sapped.

The third definition, finally, refers to an institutional distinction, where economy and civil society are assumed to contrast with the political in the form of the state and its various institutions. Clearly, this form of application also risks becoming reified when regarded as an absolute, where $\mathrm{x}$ either is the social or it is not, just as Benhabib does in her presentation. However, this is hardly unique to the social; it applies equally to any other

${ }^{153}$ Seyla Benhabib, The Reluctant Modernism of Hannah Arendt (Thousand Oaks, CA: Sage Publications, 1996), 158. This is similar to how Benhabib argues, although she is very detailed, dedicating almost 30 pages to the distinction between the political and the social, see: Benhabib 1996: 138ff. And one could add in passing that it was against such misinterpretations that I wanted to guard myself when stressing "the social" as a heuristic tool, see: Wedin 2017b, 205.

${ }^{154}$ Arendt 1998, 46.

155 Benhabib 1996, 140.

${ }^{156}$ In The Promise of Politics, Arendt claims that "in psychological terms, one might say that it is the fundamental conviction that a group of people share", Arendt 2007, 195. Cf also: Richard Sennett, The Fall of Public Man (New York: W.W. Norton \& Company, 1992). 
analytical concept - class, race, ideology, capital, etc. As such, we need to be sure not to apply them sloppily, and carefully subject them to examination by probing whether or not they are able to clarify empirical phenomena and improve our understanding of them. Thus, while Benhabib's distinctions, generally speaking, are illuminating, I contend that her dismissal of the social as a fruitful concept for examining institutions is based on a straw man argument. When defined as givens, where the social refers to "the economy and the civil society", and the political to the "public sphere, the state and its institutions", then clearly the revelatory quality seems to be minimal. ${ }^{157}$

However, the relevant question to pose when examining institutions such as the educational system by mobilising the concept of the social is rather whether or not the change $\mathrm{x}$ is rendered more comprehensible by our theorisation of the concept. By tackling the problem of education with what Arendt refers to as "the world" as a point of reference, I argue that the social can help us to better understand the transmutations of the educational system. When operationalising the concept in the second study, I do not therefore assume any inherent qualities of actual public institutions; instead, I argue that we can mobilise the social as an analytical construct serving to disclose what seems to be a successive change throughout the post-war period, and that this shift indicates a hitherto overlooked strand of continuity within educational politics from 1945-2000. Thus, I do not assume that the actual public sector is either one thing or the other, but rather that its emphasis has shifted, and that this gradual movement is pivotal in understanding the reforms throughout the period.

That said, a clarifying remark is in order before proceeding. At a high level of abstraction, the bonds between the public educational system and capitalism, with the labour market as the principal connection between the two, are indissoluble; in all industrialised states, the two have expanded in parallel. ${ }^{158}$ When Arendt thus claims that the emergence of the modern state

${ }^{57}$ Benhabib 1996, 140.

158 As, among others, the Swedish literary historian Lars Pettersson has shown, there was a range of reasons behind the emergence of a public educational system in Sweden. Firstly, it should be understood as the upshot of progressive reformers who wished to provide everyone, i.e. also those who did not have parents with sufficient means to pay for their education, with a basic education. The motivational forces behind this defence of basic education for everyone is, from this perspective, principally seen as a benevolent endeavour to improve the situation of the poor, who at the time was also intimately associated with the countryside, not only because most children lived there, but also because schooling provision was extremely poor there. A second reason was the population growth (from 2.4 to 3.5 million inhabitants during the period 1810-1850) and the subsequent growing proletarianisation. The emergence of a public educational system should here be understood as an answer to this development: a proactive measure to handle the threats that the increasing number of proletarians might pose to 
replaces the tyranny of the absolute monarchy with a no-man's rule in the form of "the assumed one interest of society as a whole in economics", the same would seem to hold for the biopolitical techniques that the same state has developed. ${ }^{159}$ However, if we accept such a narrative of decline without qualifications, it really does not make much sense to discuss the social as a relative concept, and it is certainly not at this level of abstraction that I have operationalised the social in my work. ${ }^{160}$

\section{Rupture and Continuity: The Transmutations of Equality}

So far, I have attempted to draw together the results from primarily the first three studies: "In Praise of the Present", "The Democratic Paradox", and "Tocqueville, Equality and Individualisation". Establishing how the emergence of the increasingly present-oriented educational policies interconnect with the social, as well as the Tocqueville-inspired imaginary form of equality, I have argued that these articles offer new perspectives on the transmutations of the ideal of equality in educational policies in the post-war period.

Of the vast array of previous studies focusing on the two latter waves of reforms - around 1990 and 2008-2011 - most have tended to emphasise how the movements fit in to a more overarching systemic change, whereby the Swedish educational system has progressively distanced itself from its post-war path, in which equality and democracy were so central. ${ }^{161}$ I have

the state. Put differently, it was a technique to deal with the so-called social question. In accordance with this explanation, a national basic education was desired both as an instrument of social and political control, and as a way of meeting the disgruntlement of the poor with some social reforms that served to legitimate the state. In this way, the state provided itself with the means for exercising a certain degree of social control, for indoctrinating its subjects in accordance with the dominant ideology, while at the very same time giving a voice to proletarian discontent. The third explanation underlines the economic incentives to construct a school system. The idea here is that through a national school system, the population will all possess a basic education and as a result be more productive. The fourth and final explanation directs its attention to the nationalistic ideas that had gradually poured into Sweden in the wake of the Napoleonic Wars. For a more detailed analysis of the implementation of the educational system in Sweden and its relationship to capitalism, see: Lars Petterson, Frihet, jämlikhet, egendom och Bentham: Utvecklingslinjer $i$ svensk folkundervisning mellan feodalism och kapitalism 18091860 (Uppsala: Studia historica Upsaliensia, 1992); see also: Henrik Edgren, "Folkskolan och grundskolan”, in Esbjörn Larsson \& Johannes Westberg (eds.), Utbildningshistoria (Lund: Studentlitteratur, 2011).

159 Arendt 1998, 40.

${ }^{160}$ Regarding Arendt's own usage of the concept, it clearly operates on different levels in her thought, see: Pitkin 1997; Benhabib 1996; Passerin d'Entrèves 1994.

161 Carlbaum 2012; Börjesson 2016; Johanna Ringarp, "From Bildung to Entrepreneurship: Trends in Education Policy in Sweden”, Policy Futures in Education 11.4 (2013): 456-464. 
nevertheless maintained that this narrative has obscured a number of politically pertinent strands of continuity. ${ }^{162}$

In so arguing, I do not, however, wish to disqualify previous studies tending towards a rupture-oriented narrative. It was in order to map the narrative outlined here in relation to earlier analyses that, in the introductory chapter, I turned to Rüsen and some of his key analytical distinctions to show how divergences in history writing can be conceived. In what follows, we will revisit these criteria, and examine how the narrative that has been forged here relates to the existing research.

The historian Johanna Ringarp, the political scientist Maria Jarl, and the educational historian Mattias Börjesson have all highlighted the openness of the political situation before the municipalisation of 1989. The reforms that followed thereafter, they argue, passed through much more smoothly than the initial municipalisation. ${ }^{163}$ Following the arguments of Jarl and Ringarp, it is therefore, Börjesson contends, reasonable to consider this as the reform that opened up the way for subsequent changes.

Simultaneously, although the municipalisation is considered to be the breaking point, Börjesson repeatedly stresses how the reforms around 1990 must be understood as the outcome of three coinciding aspects. Firstly, the economic crisis that was triggered by the cancellation of the real estate investor Nyckeln in 1990, instigating what would turn out to be the worst economic crisis in Sweden since the Great Depression of the 1930s. Secondly, the political struggle between different groups in society to which the struggle of municipalisation attests. Thirdly, there is what Börjesson refers to as the "ideological" dimension, where attention is on discursive transformations. ${ }^{164}$ Börjesson follows others, such as the educational scientist

162 The similarities between the impulses from the 1970s and the 1990s have also been noted by the Swedish economic historian Ylva Hasselberg, who has stressed how both new pedagogical techniques in the 1970 s and the later emphasis on economic efficiency overlook the end of education by focusing solely on the means, see: Ylva Hasselberg, Vem vill leva $i$ kunskapssamhället? Essäer om universitetet och samtiden (Hedemora: Gidlunds, 2009), 78. See also: Larsson 2002.

163 Ringarp 2011; Maria Jarl \& Linda Rönnberg, Skolpolitik: från riksdagshuset till klassrum (Stockholm: Liber, 2010); Jarl 2012; Börjesson 2016. By focusing in particular on the openness of the question of municipalisation and the divergence of opinions almost until the final decision was taken, Ringarp's study is also worth highlighting for what differrent approaches are evident, as well as, implicitly, the limits of the form of analysis that I have pursued. As indicated in the introductory chapter, the forms of horizontal qualifications made in Ringarp's elucidating study are essential for enhancing our understanding of the past, and it is important to bear this in mind when reading this thesis, where the parallel undercurrents of continuity stand at the centre.

${ }_{164}$ The author also refers to this as the preferred perspective of "poststructuralist curriculum theory”, Börjesson 2016, 52f. Clearly, the author wishes to encapsulate the 
Tomas Englund, in arguing that the move away from discussing school as a "public good" and instead viewing it as a "private good" was a crucial factor in bringing about the systemic change. ${ }^{165}$ For Börjesson, systemic change was the culmination of a mixture of these three factors, with the municipalisation serving as the decisive, triggering moment, the break from which the ensuing reforms would follow. ${ }^{166}$

When deciding how best to examine the issues that have shaped this thesis, I distinguished between two ways of proceeding: to examine the policy documents horizontally, or to do so vertically. Opting for the latter, I have argued that the variable ways in which pupils, teachers, as well as what the former should learn, are manifestations of transformations in the idea of equality, understood as a politico-temporal ideal. How, then, could the initially outlined dimensions of validity in Rüsen's reflections on historiography and justification be mobilised to set apart the present study from previous analyses? ${ }^{167}$

In order to structure his analysis, Börjesson develops six different analytical categories, a bundle of ideal-typical "principles" drawing on Amy Gutmann's classical distinctions, through which he examines the evolving discourses around educational policy. ${ }^{168}$ Among these, most are designed in order to determine public and private influence on the educational system, based on an implicit left-right political scale, with principles such as the "market" principle and the "equality" principle, each of which clearly also indicate a political tendency. ${ }^{169}$ Of these, there is one analytical construct that, revealingly, does not play a prominent role in his analysis; namely what he refers to as the "principle of user influence" (brukarinflytandeprincipen). This principle, Börjesson claims, emerged in the 1970 s as an attempt to develop a more pupil-oriented pedagogics, as well as democratising school via increased involvement by parents and pupils, which "to sum up [...] denotes a private influence over the governing of school". ${ }^{170}$

greater role ascribed to language in humanistic and social sciences with what, since the second half of the 1960s, has been designated as the "linguistic turn".

165 Tomas Englund, “Utbildning som 'public good' eller 'private good'?”, in Tomas Englund (ed.), Utbildningspolitiskt systemskifte? (Stockholm: HLS Förlag, 1996), $107 \mathrm{ff}$.

${ }^{166}$ Börjesson 2016, 210.

167 Rüsen 2004, 69.

168 Amy Gutmann is a political theorist who, in Democratic Education, distinguishes between four ideal-typical state orders: Family State; State of Families; State of Individuals; and the Democratic State. The distinctions have been widely used as an analytical scheme with which to examine educational orders, see: Amy Gutmann, Democratic Education (Princeton: Princeton University Press, 1987).

169 Börjesson 2016, 60ff.

170 Börjesson 2016, 65. 
This dimension coincides with my arguments insofar as it showcases how the cycle of reforms around 1990 must also be understood in light of the successive shift - the furthering of the democratisation - during the 1970s, manifested in particular by The Working Environment report from the major commission regarding the inner working of the school, pursued between 1970 and 1974. ${ }^{171}$ My findings thus tie in with and augment what Börjesson calls the emergence and expansion of the "principle of user influence" - an analytical construct whose major merit is to highlight the ideological continuity between the 1970 s and the 1990s. When conceiving it as "a weak tendency towards an increased private influence over the governing of school", I maintain that Börjesson underestimates the politico-temporal shifts taking place here. ${ }^{172}$ By contrast, I have sought to note how multiple and divergent features can be subsumed under this principle, cutting across many of the other political dimensions through which school is envisioned within educational research. ${ }^{173}$ In order to further my results from this point, in the following I will discuss how my results interlock with the three dimensions set out by Börjesson - namely the economic, the political, and the ideological.

In respect of the economic dimension, Börjesson stresses the importance of the deteriorating economic situation, and in particular the major crisis that Sweden underwent in the early 1990s, for understanding the shift around 1990. I have no issues with this explanation, and it does indeed seem plausible that the impaired economic situation "was a contributory factor in getting the question of educational cost efficiency onto the agenda". ${ }^{174}$ However, as indicated in the fourth article, the impulses discerned in this thesis also point to the transmutations of the capitalist system from a production-oriented order to an increasingly financial and consumer-oriented system from the 1960 s onwards, with its accompanying spatio-temporal compression. ${ }^{175}$ How my results interconnect with and perhaps deviate from these shifts, with particular attention given to the notion of equality, is outlined in Excursus II, "The Primacy of the Political?"

\footnotetext{
171 Börjesson 2016, 82ff.

172 Börjesson 2016, 98.

${ }_{173}$ The title of Börjesson's thesis, From Equivalence to Market, reflects an oft-repeated narrative structure.

174 "en bidragande orsak till att frågan om skolans kostnader och effektivitet fördes upp på den utbildningspolitiska dagordningen”, Börjesson 2016, 208.

175 David Harvey, The Condition of Postmodernity: An Inquiry into the Origins of Cultural Change (Oxford: Wiley-Blackwell, 1991), 63, 284ff; Fredric Jameson, "Postmodernism: The Cultural Logic of late Capitalism”, Nerw Left Review 146 (1984): 53-92.
} 
In relation to the second dimension - that societal changes are the partial upshot of political struggles between different groups in society - I agree entirely: in light of Ringarp's and Börjesson's convincing analyses of the debates regarding the first major reform around 1990 - the transferral of the operative responsibility from the state to the municipalities - it would seem difficult to deny this aspect. What is more, as Börjesson points out, it seems plausible to conceive of the municipalisation as a pivotal reform, forging the path for future educational reforms.

In many respects, the third dimension - the ideological dimension - is the one that best illustrates my results. Contrary to what one might expect, ideology is here not envisioned as it is applied in political science as an analytical term, nor in the sense with which it is used within the Marxist tradition; instead, it refers to how educational policy shifts should be understood as the outcome of struggles between various discourses. From this point of view, as Börjesson argues with reference to previous studies, one can justifiably assume that the emerging market-oriented discourses advocating a voucher system were "a contributory factor" to the reforms around $1990 . .^{176}$

However, as he rightly points out, this explanation clearly begs the question of why these discourses gained momentum in the 1980s, and were eventually implemented. As indicated previously, Börjesson's answer to this is that the outcome of the struggle concerning the municipalisation was crucial.

In this regard, my findings demonstrate how the shift around 1990 - and in particular the introduction of a voucher system - must also be seen in light of the previous strengthening of support for a specific form of equality, and the temporal logic with which this was coupled. More specifically, I have contended that the left-tinged critique - that emphasised the importance of transferring more influence to the pupils at the expense of the content taught and the influence of authorities, as exemplified by the teachers should also be seen as contributing to a weakening of the extant educational system. ${ }^{177}$ They did so by surreptitiously undermining the terrain on which

${ }^{176}$ Börjesson 2016, 210. The previous studies to which he refers are: Englund 1996; Magnus Dahlstedt, "I val(o)frihetens spår. Segregation, differentiering och två decennier av skolreformer", Pedagogisk forskning i Sverige 12:1 (2007): 20-38.

177 Clearly, how political categories such as left and right are defined changes over time, and both are malleable concepts. In an article written by the educational scientists Staf Callewaert \& Daniel Kallós, it is argued that the purportedly radical ideas placing the pupil at the centre towards the end of the 1960s, and in particular the emphasis on dialogical pedagogics, appear like the outcomes of a pink wave in educational policies rather than a red. Whether this is an apt way of describing these policies, as well as the more general question regarding what the presented results eventually have to say about the transmutations of the Swedish left, are both questions falling outside the purview of this study. See: Staf Callewaert \& Daniel Kallós, "Den rosa vågen i svensk 
an eventual counter-attack could have been mounted when the demands for a voucher system were forwarded by the liberal party Moderaterna from the 1980 s onwards. ${ }^{178}$ After having criticised the pre-democratic shackles that held back the individual, these influential voices from the left voiced a criticism to which the voucher system could be considered the "right-wing" liberal answer. This is a strand of ideological continuity that emerges first when we examine societal changes as interventions, as I defined them in the introduction, as temporally expanded discourses, which are discernible only when tackled in a diachronic fashion.

Now, clearly this does not entail that the well documented mobilisation of the political right from the 1970 s onwards, as exemplified by the foundation of the pro-liberal think tank Timbro, were without any effects; on the contrary. ${ }^{179}$ What I do claim, however, is that the changes around 1990 appear in a different light when analysed from a historico-political perspective. As I have tried to argue in this thesis, the proclaimed shift must also be understood as the result of an emancipatory impulse constitutive of modernity itself - namely an egalitarian impulse focusing on the individual at the expense of the collective, and the present at the expense of the past and future, as was presciently formulated by Marx and Engels in the Manifesto. ${ }^{180}$

Clearly, this impulse must not be understood as some form of Spirit deploying itself in time. I agree entirely with Börjesson that the ways in which this impulse - the modern desideratum of equality - has been handled differently at different times, and that its trajectory, the way in which it has successfully been vindicated in the post-war period, is also the outcome of political struggles and concurrent changes in material conditions. But nevertheless, there seems to be an underlying political impulse, which, within the plethora of political struggles, has made its way through and has been strengthened as the project to democratise society has progressed through-

pedagogik”, in Staffan Selander (ed.), Forskning om utbildning: An antologi (Stockholm: Brutus Östlings Bokförlag, 1992), 32-41; Daniel Kallós, Den nya pedagogiken: En analys av den $s k$ dialogpedagogiken som svenskt samhällsfenomen (Stockholm: Wahlström \& Widstrand, 1979).

${ }_{178}$ Sun-Joon Wang, "Kampen om begreppet valfrihet i skolpolitiken”, Kommunal ekonomi och politik 6.2 (2002): 7-44; Jarl \& Rönnberg 2010, 75. With regard to the politicotemporal analysis of equality around which this thesis revolves, the differences between Moderaterna and the Social Democrats as to what concerns freedom to choose in welfare terms essentially only confirm the central conclusions of this thesis, see: Matilde Millares, Att välja välfärd: Politiska berättelser om valfrihet (Stockholm: Stockholms universitet, 2015).

179 Kristina Boréus, Högervåg: Nyliberalismen och kampen om språket 1969-1989 (Stockholm: Tiden, 1994).

180 And then, as outlined above, developed much later in e.g. Rosa's idea of acceleration. 
out the post-war period. ${ }^{181}$ This is how the present dissertation, returning to Rüsen's three categories, brings new findings to the field by showing how novel and meaningful results can be extracted from known material by combining facticity and meaning in innovative ways.

The results presented herein also qualify the many studies in which educational equality has been viewed as a principle for distributing some good or welfare among individuals. Overemphasising this aspect of equality, I maintain, leads us astray politically. ${ }^{182}$ According to a well-established interpretation of educational politics with regard to the concept of equality, it is understood as a movement from a formalist ideal of equality to the post-war ideal of equal opportunity. Initially, this was interpreted as ensuring equal access, but it was then gradually replaced by a compensatory - "real" - ideal of opportunity, or equality of outcome, which in the 1970s opened up the way for the introduction of the idea of a truly equivalent education - an adaptation to local circumstances in order to better realise the underlying ideals. ${ }^{183}$ Michael Young's dystopian The Rise of the Meritocracy is often evoked as an exemplification of the instrumentalist rationalism that, towards the end of the 1960 s, was challenged by a more needs-oriented principle - "to each and one according to his or her needs" - for the educational system. ${ }^{184}$

Thereafter, in the 1980s, the concept of equivalence was integrated into a discourse structured around key ideas such as efficiency, equivalence, and decentralisation, all of which were pivotal in the discourse surrounding the reforms of the 1990s. ${ }^{185}$ Thus, having once been a tool for the protectors of equality, the concept of equivalence was appropriated by those advocating individualism in the second half of the 1980s, when, as Boman puts it, "the traditional Swedish educational politics" was abandoned. ${ }^{186}$

181 As noted, Excursus II outlines how this energy in future research could be furthered by conceiving of it in light of the fundamental structural changes to the economic system.

182 Cf. Rosanvallon 2011, 405f.

${ }^{183}$ Both Boman and Englund emphasise how the educational policy shift from the second half of the 1960s onwards should be considered as a move towards an outcome-oriented ideal of equality, see: Boman 2002, 263ff; Englund 2005, $313 \mathrm{ff}$.

${ }^{184}$ See Boman 2002, 277; Michael Young, The Rise of the Meritocracy 1870-2033: An Essay on Education and Equality (London: Penguin Books, 1961). For an analysis of the limits of Young's classical thesis, and in particular on the limits of his critique with the reformation of the educational system in Britain as an example, see: Gary McCulloch, Philosophers and Kings: Education for Leadership in Modern England (Cambridge: Cambridge University Press, 1991).

${ }^{185}$ Interestingly, in Englund's thesis on the educational reforms, written during the first half of the 1980s, he writes that it remains an open question as to the direction to which schools would be oriented following the 1970s reforms, see: Englund 2005, 278.

186 Boman 2002, 324; Quennerstedt \& Englund 2009, 19; Lindensjö \& Lundgren 2014, 88f. 
The problem with this way of analysing the policy changes, and the individualist and the distributive focus on which it is structured, is that it obscures our understanding of education as something beyond the distribution of welfare; it prevents us from seeing equality as a political ideal, with a bearing on society as a community across time. And by averting our attention from the political dimension of equality, by implicitly reducing it to a form of individually based distribution, it also, by implication, saps our capacity to envision the long-term practice of freedom to the benefit of the punctuality of liberation, where freedom implies tearing down obstacles. ${ }^{187}$

Thus, when Boman argues that an important impulse behind the educational policy shifts at the end of the 1960s and 1970 s was an attempt to further the process of democratising the school, with a view to including pupils in the formation of the content, I agree. I also concur with her remark that a democratic educational system should address "actual problems of society", and have its "context and various implications [...] transformed into objects of teaching". ${ }^{188}$

However, one of the key findings of the present thesis is that the ways in which these attempts were promoted in policy documents indicate that over time the ideal turned into one of immediacy and an overemphasis on the unmediated here and now. Or, to put it in more Arendtian terms, that the moment of negation was strengthened at the expense of the defence of the world, which, as I elaborate on in study four, "transcends our life-span into past and future alike". ${ }^{189}$ Therefore, while Boman's analyses of the metamorphoses of the idea of equality also touch on the relationship between the individual and the collective, the absence of a temporal dimension inhibits her from discerning the strand of continuity in educational policies between the 1970 s through to the 1980 s and into the 1990s. ${ }^{190}$

${ }_{187}$ With regard to the temporal dimension, Dennis McKerlie's and Richard Sikora's introduction of the temporal dimension was definitely an important development of the discussions around the concept of equality that came in the wake of Ronald Dworkin's seminal double article "What is Equality?" (parts 1 \& 2) in 1981 (from which the Swedish debate on educational equality stems), but which remained within the confines of goods to be distributed among individuals, see: Dennis McKerlie, "Equality and Time", Ethics 99.3 (1989): 475-491; Richard I. Sikora, "Six Viewpoints for Assessing Egalitarian Distribution Schemes”, Ethics 99.3 (1989): 492-502. Moreover, as Rosanvallon rightly remarks, only when freedom is considered "a capacity attributed to the individual" is it transformed into a normative opposite of equality, see: Rosanvallon 2011, 406. For a bold and thought-provoking analysis of how this idea of freedom emerged in Western political thought, see: Arendt 2006a, "What is Freedom?".

188 Boman 2002, 317.

189 Arendt 1998, 55.

190 Boman 2002, 323. Her argumentation coincides closely with that of Englund in Englund 2005. 
A very different approach can be found in Henrik Berggren and Lars Trädgårdh's study, Is the Swede Human? (Är svensken en människa?), to understand the specific relationship between the state and the individual in modern Swedish society. ${ }^{191}$ Their thesis is that Sweden's cultural and political history is characterised by a distinct relationship between the state and the individual that stretches far back in time. They do, however, concede that the centre of gravity has tilted towards the individual over the last 30 years, and that this has had two noteworthy effects.

The first is that the transferral of influence towards the individual, apart from being concomitant with various market models, has also engendered new measures of control to supervise what was intended as a deregulation: the controlling state thus soon reappeared through the backdoor, so to speak. ${ }^{192}$ The other dimension that the authors highlight is the "dissolution of nationally integrating institutions." ${ }_{193}$ Examples of such institutions include the military service and the comprehensive school system, which the authors claim have "constituted the binding in the alliance between state and individual". ${ }^{194}$

By deploying the historico-political approach, I have been able to identify key politico-temporal aspects of the problem that serve to complement, in many respects, the cultural-historical approach of Berggren and Trädgårdh's study. Whereas they mobilise Ferdinand Tönnies's classical distinction between Gemeinschaft and Gesellschaft to argue that Sweden is much more of a Gesellschaft than is often claimed, the present thesis should be seen as an analysis of the politico-temporal aporias of what Tönnies called die Gesellschaft. ${ }^{195}$ Furthermore, in contrast to Berggren and Trädgårdh's em-

${ }^{191}$ Henrik Berggren \& Lars Trädgårdh, Är svensken en människa (Stockholm: Norstedts, 2014).

192 A number of studies have noted how the state has again become more interventionist, see e.g.: Milbank \& Pabst 2016. In the specific case of the educational system, Sven-Eric Liedman has invented the apt term "pseudo-quantities" for the phenomenon of the quantifiable structuring the teacher, rather than vice versa. See: Sven-Eric Liedman, "Marknaden och viljan att mäta", in Magnus Dahlstedt \& Andreas Fejes (eds.), Skolan, marknaden och framtiden (Lund: Studentlitteratur, 2018).

${ }_{193}$ Besides the educational system, the dissolution of the state's monopolies over radio and television at the end of the 1980 s are just two examples of other structural changes in Sweden throughout the period.

${ }^{194}$ Berggren \& Trädgårdh 2014, 375.

195 Ferdinand Tönnies, Community and Civil Society (Cambridge: Cambridge University Press, 2001 [1887]), 247ff. The claim of Berggren \& Trädgårdh is straightforward: contrary to the Gemeinschaft-inspired notions that the ideal of Folkhem invokes in many, Sweden actually bears more resemblance to a far-reaching Gesellschaft with a population with a developed sense of individual independence that is rooted in a collective identity dating back to the nineteenth century, see: Berggren \& Trädgårdh 2014, 22. 
phasis on the strands of continuity going back to the nineteenth century, and indeed even further, the historico-political approach of the present thesis, building on previous studies in educational history, clearly indicates how the experiences of the war signalled a rupture. ${ }^{196}$

In contrast to the narratives portrayed, which, in their way, have advanced our understanding of how various factors should be positioned in relation to one another, I have focused on an impulse that appears in multiple guises, all of which, however, can be connected to an imaginary equality. It is primarily via this implicit but nevertheless identifiable impulse, that stretches far back in time, that I have attempted to qualify the discussions around the immediate causes, and, by extension, the shift from equality to an increasingly unequal order.

In other words, the present findings could be conceived of as supplementing previous analyses of the changes by exploring the politico-temporal ideological conditions of possibilities for the manifest "neoliberalisation" of the educational system. The thesis adds to previous studies not by rebuffing the undeniable transformations that were realised around 1990, but rather by rendering our understanding of them richer and more nuanced by way of a politico-temporal analysis of equality.

Speaking with Rüsen, the historico-political approach marks an attempt to enhance our self-understanding by envisioning equality as a politicotemporal problem in educational policies; as such, it clearly pertains to what

196 In contrast to Berggren \& Trädgårdh's narrative of a deep-seated statist-individualism, the Swedish historian Johan Östling argues that the post-war cultural and political landscape must be understood in light of the experiences of Nazism. Approaching the problem as a general societal question, he highlights how the experiences of Nazism brought about changes in a number of societal spheres, as exemplified not least in the educational system where the experiences were institutionalised, in addition to the strong influence of cultural radicalism within the educational sphere, among many others. My study thus coincides, in a number of respects, with Östling's work, although my emphasis on the political repercussions has led me to emphasise somewhat different aspects. However, while stressing the importance of the experiences of the war, I have concurrently focused on how the politico-temporal aporia of equality must also be understood in parallel with modernity as such, and not merely with regard to one of its most enigmatic and foulest manifestations, namely totalitarianism, see: Östling 2008. There are, for example, aspects of the tendencies set out here that tie in with the cultural radicalism that deeply inspired Swedish society from the early twentieth century onwards. For elucidating studies of the cultural radical rationalism in Sweden and its societal influence from the 1920 s onwards, see e.g.: Staffan Källström, Den gode nihilisten (Stockholm: Raben \& Sjögren, 1986), especially chapter 4; Crister Skoglund, Vita mössor under röda fanor: Vänsterstudenter, kulturradikalism och bildningsideal $i$ Sverige 1880-1940 (Stockholm: Almqvist \& Wiksell, 1991), especially chapter 5. That these rationalistic ideas overlap with some of the tendencies outlined here is undeniable; however, the forms that such connections took, and their importance, are questions that go beyond the scope of this thesis. 
he refers to as the normative dimension and not the empirical. ${ }^{197}$ Furthermore, in order to enhance the narrative reliability of the thesis in its totality, which, as Rüsen stresses, must not be reduced to the satisfaction of the empirical and normative dimensions, in what follows, after Excursus II, I will elaborate on how my results fit in with other, closely associated politico-temporal problems.

As mentioned in the introductory chapter, by adopting a longer historical perspective and the historico-political approach, the present thesis seeks to fulfil the previous research of others, such as the work of the historian Niklas Stenlås and economic historian Ylva Hasselberg, in addition to the work pursued at the centre of educational sociology in Uppsala. ${ }^{198}$ Tackling the teacher reforms in light of other educational reforms throughout the period, as forming part of a comprehensive politico-temporal shift throughout the post-war period, I have attempted to further elaborate on the tendencies identified in their studies. In particular, Hasselberg and Stenlås's understanding of the changes introduced in the 1990s coincides closely with the successive reinforcement of a negating critique during the same period. As such, my results provide a historico-political context for the de-professionalisation analysed by Hasselberg and Stenlås.

Recall that, in the introductory chapter, I presented Rüsen's three differrent conditions of historical narrative, in contrast to other forms of narratives. I argued that there are two conditions - two dimensions - that would be of particular relevance for this thesis. These are the extent to which the author is able (i) to reflect on the normative substance of the narrative (which should aim at extending our perspectives); and (ii) to theorise her findings and effectively combine facticity - the artefacts - and meaning into a coherent historical narrative.

So far, I have focused on my findings regarding how the idea of equality has been envisaged between 1945-2000 in politico-temporal terms, and, as my argumentation has unfolded, a number of more overarching problems have emerged. In order to further the complex of problems around which the thesis revolves - equality as a politico-temporal problem - in what follows I will expand upon what I have referred to as the aporia of equality and the democratic paradox from a more general political-theoretical perspective. More specifically, I will ask: what is the normative substance of the supplementing narrative defended here? And how does this relate to corre-

\footnotetext{
197 Rüsen 2004, 66.
}

198 Hasselberg 2009; Hasselberg \& Stenlås 2012; Stenlås 2009; Albäck Öberg et al. 2016; Stenlås 2011; Gustavsson et al. 2016; Broady et al. 2009; Bertilsson 2014; Broady et al. 2006. 
sponding political-theoretical issues? These questions will be addressed in the section that follows the excursus below.

\section{Excursus II: The Primacy of the Political? ${ }^{199}$}

In light of the conspicuous absence of reflections on the noted changes and their interdependence with external factors, in particular the close bonds between the educational system and the capitalist system since the emergence of public education in the nineteenth century, it is crucial to at least indicate how my results could be taken up in future studies.

As Fredric Jameson, one of the most influential Western Marxist thinkers since the 1980s, has argued, a relevant aspect of the societal shifts that have occurred since the 1970s is the dislocation of the conception of time, which increasingly seems to be characterised by a "fragmentation of time into a series of perpetual presents". ${ }^{200}$ Jameson maintains that the further geographical expansion of the capitalist order has eradicated the pre-modern pockets that previously existed, and that, as a consequence, the historical phase characterised by the simultaneity of the non-simultaneous has passed. ${ }^{201}$ Besides bringing about a universalisation of wage-labour, this has had the effect of eradicating earlier ways of organising societies, and with that the very phenomenological experience of the past. ${ }^{202}$ In its place, a social system emerged that has

199 The ensuing analysis draws on an article in which I discuss three traditions that engage with what I call an imaginary equality. Alongside the Arendtian "political" approach and the Western Marxist tradition, I also include here John Milbank as representative of a theological approach to the outlined dynamic, see: Tomas Wedin, "The Problem with Modern Equality: Three Theoretical Approaches", unpublished paper. Milbank outlines his approach in e.g.: John Milbank \& Adrian Pabst, The Politics of Virtue: Post-liberalism and the Human Future (London: Rowman \& Littlefield, 2016); John Milbank, "Against Human Rights: Liberty in the Western Tradition", Oxford Journal of Law and Religion, 1.1 (2012): 203-234; John Milbank, "Culture and Justice", Theory, Culture \& Society 27.6 (2010): 107-124; John Milbank, Theology and Social Theory: Beyond Secular Reason (Oxford: Wiley \& Blackwell, 2006).

200 Jameson 2009, 20.

201 The idea of the simultaneity of the non-simultaneous is borrowed from Ernst Bloch, see: Ernst Bloch, "Nonsynchronism and the Obligation to Its Dialectics", New German Critique 11 (1977): 24f.

202 Fredric Jameson, Postmodernism, or, The Cultural Logic of Late Capitalism (London: Verso, 1992), 310. 


\section{THE APORIA OF EQUALITY}

[...] little by little begun to lose its capacity to retain its own past, has begun to live in a perpetual present and in a perpetual change that obliterates traditions of the kind which all earlier social formations have had in one way or another to preserve. ${ }^{203}$

The new ways of orienting in time, argues Jameson, are concomitant with the emergence of a new form of equality; but it is, to be sure, not an unqualified process of equalisation that we are witnessing. On the contrary, it is a domain-specific form of equality, centred round the social and cultural spheres. In terms of the economic sphere, this is not simply left out; it has moved in the opposite direction:

[...] the new cultural equality [...] is infused with a powerful hatred of hierarchy and special privileges and with a passionate resentment of caste distinctions and inherited superiority. It is permitted to be wealthy, as long as the rich man is as vulgar as everyone else: this general democratic impulse is negative rather than positive, it is fired by a passion for egalitarianism which is not quite the same as resentment against success (although it can easy degenerate into that), and which is akin to the older mob spirit without being revolutionary $[\ldots] .204$

On other words, we must "understand this process socially and culturally, rather than economically". ${ }^{205}$

Now, the paramount difference between Arendt, with whom I have sustained a dialogue here, and Jameson is the historico-political assumption of the "absent cause" in the latter's thought: the assumption that, in the last instance, the outlined transmutations are structurally related to the mode of production. ${ }^{206}$ This structure must not, however, be understood in a mechanical, causal sense in the manner of a billiard-ball relationship, where one part is immediately, causally related to the others, yet nor should it be understood through the form of some theological order, as the last of Aristotle's four causes. The cause is "absent" insofar as it is the structurally articulated form of its effects; and this absent structure, identifiable only through its effects, is the "mode of production itself, or the synchronic system of social relations as a whole". ${ }^{207}$ The absent cause ought, therefore, to be understood as mediated rather than an immediate causal relationship. Put differently, the structure determines the phenomenon at hand, but only via

\footnotetext{
203 Fredric Jameson, The Cultural Turn: Selected Writings on the Postmodern, 1983-1998 (London: Verso, 2009), 20.

${ }^{204}$ Fredric Jameson, The Hegel Variations: On the Phenomenology of Spirit (London: Verso, 2010), 101-102.

205 Jameson 2010, 101.

206 Fredric Jameson, The Political Unconscious: Narrative as a Socially Symbolic Act (London: Routledge, 2002), 20.

207 Jameson 2002, 21.
} 
diverse media, including contradictory manifestations. ${ }^{208}$ And, indeed, when considered diachronically, as in contrast to an on-the-spot account, it does seem hard to imagine a similar form of equality expanding in any other (non-capitalist) society, in any other epoch. Thus, analogous to how Jameson argues that it is essential to address the background - "the experience of anomie, standardisation, rationalising de-sacralisation in the Umwelt or world of daily life" - against which cultural artefacts were fabricated in modernity, the dynamics set out here do seem to interlock with the transmutations of the economy. ${ }^{209}$ Hence, we appear to have good reasons for comprehending them - the imaginary form of equality and the changes in the economy - as intertwined.

Although this argumentation appears completely alien to the fierce refusal of any attempt to systematise an order - in this case in the form of a structure - of history in Arendt's thought, it is, I maintain, an open question as to how the Arendtian inclinations outlined here relate to Jameson's approach. ${ }^{210}$ Assuming that his approach is sound, that it is justifiable to think of the changing mode of production as an absent cause, "apprehended only through its effects, and never directly as some reified force", does - or could - this encompass an understanding of the educational sphere along the lines of what has been proposed here?"211 That is to say, what does "a genuinely historical and dialectical analysis" amount to? ${ }^{212}$ My usage of the social as an analytical term is, in this regard, a telling example. As noted in the section on the social, it is clearly the case that the public educational system and capitalism, with the labour market as the main unifying link, at a high level of abstraction, have an undeniable affinity. ${ }^{213}$ Or, put differently, there is a non-causal context with which the outlined changes resonate, and yet they cannot be reduced to the outcomes of the transmutations of capitalism - that is, "as some reified force". ${ }^{14}$

\footnotetext{
208 Jameson 2002, 27.

209 Jameson 2002, 27.

210 Jameson 1984, 63.

211 Jameson 2002, 88.

212 Jameson 1984, 62. As Jameson puts it elsewhere, "does it possess some autonomous force in which it could also be seen as negating that context", i.e. rather than "reflecting" it? See: Jameson 2002, 23.

213 Understanding the social against this backdrop also seems to take the sting out of Hannah Fenichel Pitkin's critique of the social as a form of reified "blob" that suddenly emerges, see: Pitkin 1998.

${ }^{214}$ Jameson 2002, 88. For an elucidating discussion of the relationship between ideas and material conditions, the diachronic and synchronic with the Swedish cultural debates as an empirical background, see: Frenander 1998, $431 \mathrm{ff}$.
} 
Whether or not some form of synthesis is possible between the two, and what benefits this might afford our understanding of the phenomena at hand, are clearly not questions to be settled here. Rather, the purpose of the present excursus has been to further my argumentation with respect to existing research. To what degree Jameson's analyses "have a revealing - or disclosing - quality" for understanding the dynamics charted here is a problem calling for further research. ${ }^{215}$

\section{The Aporia of Equality}

One theme that runs through all four articles is that the transformations in educational policies throughout the period are indicative of what I have called an aporia of equality. By giving more and more influence to individual pupils' personal experiences and the right to have their say, I have argued that certain impulses, which have been promoted by various actors in differrent spheres of society, have contributed to a gradual dilution of the collective democratic order that the reforms were initially set up to enhance. Moreover, I have claimed that this aporia, this self-defeating impulse, literally "without passage" (a poros), within the confines of its own logic, sheds new light on the reforms around 1990, which are widely seen as heralding a systemic shift.

In the following pages, I will elaborate on the findings of my fourth study, that is, on the constructive discussion about Arendt's reflections on the relation between education and politics, and how these could be mobilised to address the politico-temporal aporia of equality. I will do this by expanding the horizon beyond the strict confines of educational policies. Initially, I will refine my understanding of her idea of the world by contrasting it with other critics of abstract individualism. In a second step, my results regarding the education system will be compared with previous politico-temporal reflections on Arendt's thought. As in the first step, the discussion here will revolve around her notion of the world.

Thereafter, in order to further the points made regarding the relationship between education and the world, and the pivotal role that the temporal dimension plays in both, in the third and final step I will turn to a foundational tension within the politics of modernity. I will demonstrate how the tension between what Arendt refers to as the exercise of freedom in time, and the negating liberation with which freedom is, sadly, all too often conflated, can be used to develop the implications of my results. ${ }^{216}$ By way of

\footnotetext{
215 Arendt quoted in Hill 1979, 319.

216 The distinction is a recurrent and pivotal theme in Arendt's thought, but a particularly elucidating presentation is expounded in: Arendt 2006b, 21ff; Hannah Arendt, "The
} 
illustration, I will outline how this distinction can be mobilised to evince a problem in the thought of two well-established contemporary political thinkers: namely Étienne Balibar and Jacques Rancière. Both have engaged in questions that, as we shall see, can draw out the political-theoretical implications of my results. More specifically, I will focus on how Balibar's reflections on universality and his idea of égaliberté, as well as Rancière's analysis of the political, can shed light on the broader political implications of the results of this thesis. However, before turning to this tension, some further remarks on the idea of the world are in order.

In contradistinction to what some of those subsumed under the "communitarian" tradition have been criticised for, Arendt's concept of the world does not fall prey to what Christopher Lasch calls the "overemphasis" on the importance of "shared values". ${ }^{217}$ Her idea of a public sphere, the discursive webs of which also (though not exclusively) constitute the world, rests instead on a trust in the political institutions upon which the world depends. These ongoing discourses serve as an arena for the partaking individuals to disclose themselves in their singularity, to reveal their "who", to use Arendtian terminology. ${ }^{.18}$ But their interventions also, and from a worldly perspective, serve to extend the narrative webs in which the individuals immerse themselves by maintaining an ongoing inter-generational and intragenerational political dialogue. As such, as many commentators have pointed out, there is both a communicative and an expressive dimension to Arendt's idea of politics and the crucial role that the world plays therein. ${ }^{219}$

In this sense, Arendt's distinction between "sheer sameness" and a "genuinely political equality that allows space between plural individuals", offers a framework for tackling culturally and religiously diverse societies like

Freedom to be Free: The Conditions and Meaning of Revolution”, in Thinking Without a Bannister: Essays in Understanding 1953-1975 (New York: Schocken Books, 2018). The tension is further analysed in: Tomas Wedin \& Carl Wilén, "Equality from the Athenian Democracy to the American Revolution: On the Limits of Modern Democracy in Arendt and Meiksins Wood", forthcoming.

217 Lasch 1986, 67.

218 See note 149 above.

219 The idea of a common political language is borrowed from Christopher Lasch, see: Lasch 1986, 64. Concerning Arendt's thought, I take what Passerin d'Entrèves has called her communicative model of action, and what Benhabib calls the narrative model of action in her thought, to be roughly interchangeable with Lasch's idea of a common political language, see: Passerin d'Entrèves 1994, 84; Benhabib 1996, 125. The disclosing potentiality for the individual is interchangeably referred to as the expressive model of action (Passerin d'Entrèves 1994, 84; agonal in Benhabib 1996, 125; and, finally, the form of republican existentialism that the political theorist Margaret Canovan outlines in: Margaret Canovan, Hannah Arendt: A Reinterpretation of Her Political Thought (Cambridge: Cambridge University Press, 1992), $201 \mathrm{ff}$. 
Sweden in ways that do not end up in the same dead-ends to which multiculturalist approaches lead (which often invoke some form of communitarian ideals).220 As Fareld aptly remarks in respect of Charles Taylor's thought, his critique of the naïve liberal idea of identity runs the risk of repeating on a collective level what he attacks on an individual level. Whereas liberal thinkers are caught-up in the tautological "I am I am...", communitarian thinking runs the risk of merely repeating the same circularity in demanding "recognition for those who we already are, because we already are those that we demand recognition for being". .21 They both risk falling prey to a pointillistic circularity according to which identity is something temporally and spatially static. 222

This circularity is closely related to Rosa's claim that politics in late modernity "has become situationalist". ${ }^{223}$ As indicated by the idea of acceleration, we seem to be confronted with an inherent paradox at the very heart of the idea of progressivism, namely that it harbours energies that are intricately intertwined with contemporary reactive - "defensive and deceleratory" - politics. ${ }^{224}$ This is not to the result of some inherent force that is detached from political practices, as a yoke under which we are suppressed; rather, it emerges from the ways in which, among other causes, the modern desire for equality has happened to be canalised, but which could have been - and still can be - mediated differently. It is in this sense that I maintain that the presentistic form of equality that grew stronger throughout the post-war period paradoxically undercuts the possibilities of public freedom,

220 Canovan 1992, 243.

221 Victoria Fareld, Att vara inom sig utom sig (Göteborg: Glänta, 2007b), 168. The liberal tradition alluded to here is the classical Anglo-Saxon tradition including such thinkers as John Locke, John Stuart Mill, and more recent representatives such as Karl Popper and John Rawls. Clearly, however, this is but one current, which indeed has been and remains very influential, alongside a number of more heterodox thinkers - such as Alexis de Tocqueville and Pierre Manent - who also claim to represent a liberal tradition. For an elucidating albeit brief analysis of what British-American political philosopher Larry Siedentop has argued is a distinct French liberal tradition, see: Larry Siedentop, “Two Liberal Traditions”, in Raf Geenens \& Helena Rosenblatt (eds.), French Liberalism from Montesquieu to the Present Day (Cambridge: Cambridge University Press, 2012).

222 I do, however, want to emphasise that I read her argument as a more general demurral against sloppy communitarianism, as exemplified in some discourses on multiculturalism, where "cultures" are considered to be reified, closed entities. Whether or not it is justified to level such a critique against Taylor falls beyond the scope of this thesis. This tension is also a central object of inquiry in Ricoeur's discussion of identity in: Ricoeur 2015.

223 Rosa 2009, 102.

224 Rosa 2009, 102. 
in spite of its otherwise noble intentions. As such, it is as an example of the politico-temporal aporia of democratic equality par excellence.

In contrast, by sustaining a dialogue with a past that incessantly haunts and interpellates us, we can extend the horizon of the future. Preserving a constant negotiation with both the insights of the past and the root-system that keeps us tied to it offers a way of undergirding the public sphere, the medium through which our current political paralysis can be addressed. ${ }^{225}$ The very maintenance of the public sphere also stands in a particular relationship to the future, since the existence of a public sphere is the medium through which we can collectively project ourselves into the future. And for such action to be possible, we need institutions that can mediate forms of collective life: an institutional framework for the members to give themselves a purposeful direction, and serve as, speaking with Gauchet, a "mediation of the political community with itself", or, in Arendtian terms, a world, encompassing "our life-span into past and future alike". ${ }^{226}$ By emphasising how the world is temporally stretched out towards both past and future, this way of tackling our current temporal provincialism also offers an alternative to what Koselleck referred to as the temporalisation of utopia, where the future was envisioned as a preordained society to be realised, a view that emerged with the modern revolutions. ${ }^{227}$

225 Throughout this thesis, my focus is on the political role of school as an institution in society, and my examples and associations are chosen accordingly. With regard to the epistemological and ontological questions at stake in the educational process, there are a number of substantial points of convergence with Hans-Georg Gadamer's reflections regarding the roles of authority and of tradition in our quest for truth. His reflections on authority, his distinction between auctoritas and potestas, coincide neatly with my Arendt-inspired argumentation in study four. See: Hans-Georg Gadamer, Truth and Method (London/New York: Continuum, 2006); Hans-Georg Gadamer, The Enigma of Health: The Art of Healing in a Scientific Age (Stanford, CA: Stanford University Press, 1996), "Authority and Critical Freedom". For an elucidating discussion and advancement of Arendt's and Gadamer's thought in epistemological, ontological, and political respects, see: Richard J. Bernstein, Beyond Objectivism and Relativism: Science, Hermeneutics, and Praxis (Philadelphia: University of Pennsylvania Press, 1983).

226 "mediation de la communauté politique avec elle-même", Marcel Gauchet, "Quand les droits de l'homme deviennent une politique", La démocratie contre elle-même (Paris: Gallimard, 2002), 384; Arendt 1998, 55. Or, as one of Gauchet's key sources of inspiration puts it: "A society cannot exist without being something for itself, which does not represent itself as being something - which is a consequence, part, and dimension of what it should articulate as 'something"' (my translation). See: Cornelius Castoriadis, La montée de l'insignifiance: les carrefours du labyrinth 3 (Paris: Éditions de Seuil, 1996), 22. See also: Cornelius Castoriadis, Figures du pensable: Les carrefours $d u$ labyrinth 6 (Paris: Éditions du Seuil, 1999), $196 \mathrm{ff.}$

227 Reinhart Koselleck, "The Temporalisation of Utopia”, in The Practice of Conceptual History: Timing History, Spacing Concepts (Stanford, CA: Stanford University Press, 2002). In Arendt's thought, what Koselleck later would denominate the temporalisation 
This stance, where past and present are seen as potentialities for expanding the horizon of the future in a relationship of mutual interdependence, should be contrasted with the defeatist surrendering of the present to the future, where the future, as if an external force, constrains the present. ${ }^{228}$ Thus, rather than promoting the need to learn how to learn, and/or focus on well-defined competences, a more content-oriented mode of education would seem to present a more appropriate strategy for instilling a greater sensibility for the malleability of our historical condition - and, by implycation, countervailing our presentist predicament.

The politico-temporal dimension in Arendt's thought is also the topic of focus in a recent work by the Swedish rhetorician Frida Buhre. She underlines how the category of homo faber has a crucial role to play in political life by emphasising the importance of constancy. ${ }^{229}$ The point of convergence between the political sphere - man as a zoon politikon - and homo faber is the discursive web that Arendt sees as interlacing individuals over time, thereby comprising a crucial aspect of the world. ${ }^{230}$ As Buhre points out, Arendt also argues that there is a crucial moment of transcendence in works of art, the products of homo faber; the reification in the art work, Arendt contends, transcends "the mere transformation"; when a thought leaves the "[ $\ldots]$ original home in the heart or head of man" to become reified and form part of the world, a transformation occurs, a veritable "metamorphosis in which it is as though the course of nature which wills that all fire burn to ashes is reverted and even dust can burst into flames". ${ }^{291}$

of utopia is a recurrent target of critique and plays a crucial role in her critique of totalitarianism, see e.g. Arendt 2004, 604ff.

228 As mentioned above, on page 55, it is an interesting paradox that the unpredictability of the future needs of the economy, which intuitively one could think would open up a window of opportunity for the educational system, in contrast had the effect of letting the future confine education to the present by focusing on techniques and competences, rather than a content through which they could stretch themselves out over time. Cf. Colla \& Wedin 2018.

229 Frida Buhre, "Hannah Arendt och framtidens dilemma", Fronesis 52-53 (2015): 219.

230 The world in Arendt's thought is something that both connects and separates the citizens. It separates by literally keeping them from falling into each other in the form of physical objects, around and through which they meet, and it unites via e.g. the shared interaction with public art (a practice which in parallel also separates, as each of us interacts with the materialisation of our world in different ways).

231 Arendt 1998, 169; Arendt 1998, 168. Arendt's formulation draws on the poem Magic by Rainer Maria Rilke. There is a notable parallel here between Fareld's apt remark that each new interpretation of the historian implies a transcendence of the historical text, Arendt's idea of the role of the artwork, and the way in which I envision the activity of transmission as something that must simultaneously aim at attuning the pupils to a more qualitative way of orienting themselves in time. See: Fareld 2007a, 53; Wedin 2018b, 17 . 
The thread that gathers together these aspects of Arendt's thought, I maintain, is her temporal sensibility, the dialectics between continuity and rupture, and the interplay between past, present, and future. But whereas I, in "Equality and Education", stress the importance of transcending strict transmission in educational practices by simultaneously attuning the pupils to a qualitative relationship to time and thereby arousing an emotional attachment to the world, Buhre stresses the dialectics between durability and novelty in the sphere of action. ${ }^{232}$ The point of convergence is Arendt's reflections on the world as a sine qua non for the temporally extended practice of freedom, and how these open up new ways of tackling our presentist situation.

What Arendt offers, although it is unlikely that she would have been comfortable with the protocol herself (given her aversion to the concept of ideology), is a politically rich form of timeology (tideologi). It is fruitful insofar as it can unlock new ways of addressing the politico-temporal aporia of equality and rethink the relationship between education and political life, with the world as its centre of gravity. ${ }^{233}$

Articulating education along these lines is not only a productive way of explicating how the past continues to address us, whatever we might think of it; it is also a useful way of rendering explicit our protean condition. ${ }^{234}$ In this regard, it also proposes a practice-oriented framework that avoids the communitarian danger of becoming trapped in the circular "we that are we that are...". ${ }^{235}$ As such, it is a strategy for countering the crippling effects of our presentist condition, serving as a counterweight to, as discussed at

232 But clearly, teachers taking this dimension seriously will attune themselves as well. With an emotional attachment to the world, I refer to Arendt's emphasis on the role of public virtues, which can serve as guiding imaginaries through which the citizens can overcome their private interests and also engage in the world. As such, the care for the world is not, Arendt emphasises, an "enlightened self-interest"; a crucial aspect of the conflict between herself as a private individual and as a citizen is precisely the different temporal orders in which they are rooted: "The principal characteristic of the common good with respect to the plurality of individuals who share it is that it is much more durable than the life of any one individual". See: Hannah Arendt, "Public Rights and Private Interests", in Thinking Without a Bannister: Essays in Understanding 1953-1975 (New York: Schocken Books, 2018), 508.

233 Victoria Fareld, “Tideologi: De politiska idéernas tidslighet”, Fronesis 52-53 (2015): 172178.

234 Similar perspectives on a renewed way of interacting with the past are discussed in, among others: Rüsen 2012; Lasch 1986.

235 Fareld 2007b, 168. 
greater length above, the paradoxical political inertia generated by the acceleration of time. ${ }^{236}$

Arendt's work of relating public freedom to her idea of the world is so fruitful precisely, though not exclusively, because it encapsulates the temporal dimension that I have discussed herein: in order to render joint action, i.e. public freedom, meaningful, participants ought to be attuned to the existence of something that transcends the satisfaction of our fleeting and private preferences. ${ }^{237}$ As exemplified above, a pivotal aspect of the outlined paradox lies in the fact that the political community through which our cherished individual rights emerge and can be protected is an abstract entity, which by definition extends over time; it is a world that temporally transcends the individual who partakes in it.238 The depletion of this institutional foundation for political freedom constitutes the crux of the aporia that I have outlined in this thesis.

\section{The Janus Face of Abstract Universality}

In On Revolution, Arendt recurrently comes back to what she sees as one of the crucial challenges to modern revolutions with their outspoken aim to create something new, namely that the very spirit of novelty, which nourishes the modern conception of revolution, nullifies itself by virtue of inhibiting the construction of an institutional framework through which the

${ }_{236}$ Lübbe 2009, 177. See also: Christoph Bouton, Le temps de l'urgence (Lormont: Le bord de l'eau, 2013); Bo Stråth, "The Faces of Modernity: Crisis, Kairos, Chronos - Koselleck Versus Hegel”, in Henning Trüper, Dipesh Chakrabarty, \& Sanjay Subrahmanyam (eds.), Historical Teleologies in the Modern World (London/New York: Bloomsbury, 2015). For an in-depth critique of the alienating effects of these tendencies of acceleration, see: Hartmut Rosa, Resonsanz: Eine Soziologie der Weltbeziehung (Berlin: Suhrkamp, 2016). For an attempt to address how these tendencies might be counteracted within the educational system, see: Alhadeff-Jones 2017.

237 Regarding the purpose of public engagement, it is an open question to what extent Arendt's thought should be distinguished from what could be called a "liberal republican" tradition, or what Larry Siedentop refers to as the French liberal tradition. I desist from further elaborating on this here. For relevant discussions of this theme, see: Benhabib 1996, 202ff; Canovan 202ff. Siedentop 2014; Margie Lloyd, "In Tocqueville's Shadow: Hannah Arendt's Liberal Republicanism”, The Review of Politics 57.1 (1995): 31-58.

238 It should be stressed that what I draw on here is Arendt's idea of the world and a public sphere as a sine qua non for political freedom, not a claim on the way she herself works as a historian, which is much more akin to Walter Benjamin's approach as laid down in his Theses on the Philosophy of History, see: Benjamin 1999. For a discussion on the similarities between the two, see: Gaye Ilhan Demiryol, "Arendt and Benjamin: Tradition, Progress and the Break with the Past", Journal of the Philosophy of History 12 (2018): 142163; Jerome Kohn, "Freedom: The Priority of the Political", in Dana Villa (ed.), The Cambridge Companion to Hannah Arendt (Cambridge: Cambridge University Press, 2002). 
practice of freedom can be protected and advanced.239 It is against this backdrop that my activation of Gauchet's reflections on the temporal aspect of political action in the fourth study should be understood. Needless to say, when democracy becomes instrumentalised so as to enhance economic growth and to serve as a vehicle for maximising the private preferences of individuals, the outlook for exercising freedom over time is rather bleak. What makes Gauchet's way of tackling the problem so apt is that he weaves it into a broader historico-political narrative, arguing that it should be seen as part of a larger liberal undercurrent, which has deep roots within political modernity. Therefore, notwithstanding the manifest transformations, most notably the conspicuous market-based forms of structuring society that have grown considerably, it is essential to also understand these reforms in light of the preceding decennia of deconstructing various forms of alleged hierarchical social structures. This is the background for the ensuing discussion, which concerns the difference between liberation and the practice of freedom.

In order to expound the dynamics that feed into the imaginary equality, Balibar's analysis of the emergence of universality as a category in modernity is highly elucidating. ${ }^{240}$ The forces behind the emerging form of equality in modernity, the inner logic of the modern rights-based idea of equality, is evident in what Balibar sees as a dialectic between two intimately related forms of universality in modern society. The first is materialised in the modern state, with its "formal" promises of a society of free and equal individuals, and which, in virtue of never fully realising the expectations prompted by these promises, could be thought of as a fictive universality.

As such, it is closely related to what he refers to as the idealistic or "real" form of equality, through which the fictive character of the formalist state, never fully redeeming its promise of égaliberté, becomes disclosed. ${ }^{241}$ In virtue of being two ideals of universality, mediated by the process of the unfolding égaliberté, the one is inconceivable without the other; the "ideal

239 Arendt 2006b.

240 Another key commentator on the emergence of Tocqueville's imaginary equality is the historian Lynn Hunt, see: Lynn Hunt, Inventing Human Rights (New York: W.W. Norton, 2008).

241 According to a logic comparable to what Hunt, in her seminal work on human rights, refers to as the inner logic of human rights, see: Hunt 2008. To be more precise, Balibar refers to this as the expansive dimension of égaliberté; expansive due to the "fact that human rights cannot be limited or restricted in their application: there is an inherent contradiction in the idea that not every human being enjoys rights which are constitutive of humanity". See: Étienne Balibar, "Ambiguous Universality”, Differences: $A$ Journal of Feminist Cultural Studies 7.1 (1995): 165. See also: Étienne Balibar, La préposition d'égaliberté (Paris: PUF, 2010). 
universality" serves, as Balibar aptly puts it, as the non-deconstructible spectre of the former. ${ }^{242}$ Nevertheless, as I shall attempt to show, it is a Janus-faced impulse.

Due to its insatiable drive to successively annihilate all manner of hierarchies and structures, and as such serving as a constant source of pressure on the inevitably exclusionary logic of the fictive universality of the modern state, as indicated by the policy changes outlined here, and on which any institutionary framework rests, the ideal universality is also an insidious depoliticising energy. In this regard, it threatens to loosen the conventional ties - the public spirit, the "capacity to respond reasonably" - on which the sustenance of any polity, i.e. a shared world, depends. ${ }^{243}$ As such, I claim that it is something of a double-edged sword, serving as an emancipatory impulse while at the same time, and through the same forces, weakening the political forms, the institutional frameworks, without which the practice of freedom is impossible.

This tension between liberation and the practice of freedom can be further explicated by evoking Jacques Rancière's defence of politics as the instantiation of the limits of the exclusionary logic on which political systems are constructed. ${ }^{244}$ For all the merits of his attempt to de-ontologise the political and replace it with a practice-oriented definition, the absence of the temporal dimension in his argumentation prevents Rancière from assessing the distinction between liberation and the practice of freedom. ${ }^{245}$ I should note here that when I mobilise Arendt's work so as to stress the pivotal role of the world, mediated via institutions, such as the educational system, this is not a surreptitious re-ontologising, if by this one means a reified way of envisioning politics (cf. my arguments in relation to the social). It is, as I

\footnotetext{
242 Balibar 1995, 164.

${ }_{243}$ The full sentence runs as follows: "In order to respond reasonably one must first of all be 'moved', and the opposite of emotional is not 'rational', whatever that may mean, but either the inability to be moved, usually a pathological phenomenon, or sentimentality, which is a perversion of feeling", Arendt 1972, 161. This way of envisioning politics ties in with Tocqueville's critique, in particular his fear of where the replacement of convention-based social bonds with natural bonds might lead us (Tocqueville 1981, 245). For an elucidating analysis of the role of emotions in Arendt's political thought, addressing in detail her often misunderstood critique of pity in the public sphere, see: Degerman 2016.

${ }_{244}$ As an example, he takes Olympe de Gouge's claim that a woman who has the right to be guillotined should also have the right to enter the rostrum, see: Jacques Rancière, Hatred of Democracy (London: Verso, 2009), 60.

245 Although in light of his reflection on the distinction between republic and politics as the former's intent to always attempt to abrogate the latter by endeavouring to foment the mores that bind it together, this could be understood as a refutation of the temporal, of democracy as incessant deconstruction, see: Rancière 2009, 63f.
} 
have argued, a defence of politics as the temporally extended practice of freedom. ${ }^{246}$ Thus, whereas the undeniable upside of the process of égaliberté is humankind's more evolved capacity to identify with other individuals in their bare humanity, it also, as I have argued throughout the thesis, contains a tendency to diminish the inevitably hierarchical and convention-based order on which the public sphere and practice of collective freedom - i.e. politics - is nourished. ${ }^{247}$

This is not to say, however, that I categorically refute Balibar and Rancière's point; I do not deny that the instantiation of the principle rendered possible through an excluded group or individual is a crucial dimension of politics. ${ }^{248}$ Well thought through and politically defensible transgressive action, to be sure, is a vital part of any thriving democracy. My point is, rather, that the conditions of possibility for any such transgressive action is that there be a clear institutional framework in the first place. In order for transgressive actions to become dynamic, they need to take shape against institutions, not within them; as such, in the latter form, they are, as this thesis confirms, self-defeating.

Admittedly, the quotidian practices of politics embedded in an institutional framework are of a much less spectacular, and hence much less impressive, character than the eruptive and decisive moments of negation, wherein various forms of constraints of political equality as well as that of the indissolubly intertwined freedom are highlighted. However, rather than envisioning them as opposites, it appears, as indicated in the paragraph above, more fruitful to conceive of them as dependent upon one another. Building on the distinction that Arendt draws between archein, the very initiation of a process, and the very practice and entertainment through which the initiating archein was pursued - prattein in ancient Greek education should here be thought of as the carrying through of the political project of democracy. ${ }^{249}$ By contrast, acts of civil disobedience and other political acts that challenge the current norms of inclusion and exclusion, as

${ }^{246}$ In "Who Is the Subject of the Rights of Man?" he develops this point by distinguishing between politics and police, or a dissensual and a consensual way of envisioning the Rights of Man; along the lines of how Balibar envisages the idealistic universality, Rancière argues that the desirable political stance towards them is to understand them as a conflictual field revolving around their substantialisation, whereas the consensual interpretation represents a reified, controlling way of envisioning them. The argumentation thus parallels the example above with de Gouge, see: Jacques Rancière, "Who Is the Subject of the Rights of Man?”, The South Atlantic Quarterly 103.2/3 (2004): 297-310.

247 Sennett 1992.

248 Arendt has also reflected on this point in: Hannah Arendt, "Civil Obedience", in Responsibility and Thinking (New York: Schocken Books, 2003).

249 Arendt 2006a, 165. 
exemplified by Olympe de Gouge in Rancière's thought, could perhaps best be thought of as galvanising moments that nourish the less spectacular practice of freedom, which ideally occurs on an everyday level, and which depends for its survival on an institutional framework.

\section{Closing Remarks}

In the concluding part, I have attempted to synthesise the various studies and to show the relevance of analysing equality as a politico-temporal problem, as well as how it relates to other narratives around the educational changes in the post-war period in Sweden. I have argued that the outlined historico-political approach brings to the fore structural contradictions that go deep into the ideological root system, thereby embedding changes such as municipalisation, marketisation, and de-professionalisation within a broader historico-political narrative. I have shown how the way in which education has been temporally charged, how it has been supposed to deploy in time, has evolved during the post-war period, and that this shift should be understood as concomitant with the emergence of a new way of conceiving equality. In relation to existing narratives that are chiefly centred round the idea of a break or rupture, I maintain that these have overlooked important strands of continuity. The present thesis supplements the existing research in its use of what I have called a vertical qualification of the historiography in respect of post-war policy reforms. By expounding how my argumenttation has repercussions on topical political discussions around equality and freedom, I have embedded the more specific educational issues within a broader normative framework.

By approaching the transmutations of how pupils, teachers, and the taught content were envisioned throughout the period as manifestations of the politico-temporal problem of equality, I have taken pains to show in what ways the dynamics of the emancipatory impulse itself engendered forces that ultimately undermined and weakened its foremost ambition namely the realisation of a democratic society. This is the gist of the aporia of equality. As I have attempted to argue in the conclusion, a potentially more productive way to rethink this political dead-end would be to see equality as a political ideal, one that is intimately bound up with the practice of freedom, in contrast to the overemphasising of liberation.

The answer to the democratic paradox of post-war educational policies is therefore not, as I hinted at in the third and fourth studies, a return to the past; rather, a better answer would entail the creation of an educational system that serves to successively introduce the newcomer to the public 
world, beyond her "individual limitations in time and space". ${ }^{250}$ The advantage of the timeology, on which this understanding of pre-graduate education is based, is that it provides a framework through which we can envision the ideal of democracy without reverting to the idea of politics as a means to some external end; in addition, education can become the work of spatially and temporally extending the individual psyche of every pupil, whilst sustaining the very world into which they are being introduced.

Furthermore, it is in this sense that I maintain that the present thesis should be understood as an internal critique of the attempts to democratise the educational system, as it ultimately serves to revitalise the idea of putting the educational system in the service of democracy. If the educational system is to be anything more than a mere means for economic growth and/or for individuals to climb the social ladder, a critique levelled against educational systems for decades, a temporally coherent alternative vision for education is needed. ${ }^{251}$ The results herein are thus a contribution to how such an attempt could be developed, drawing on a qualitatively more differrentiated time, alongside an idea of equality as a partaking in public life.

As a framework that seeks to render human action - and hence substantial change - possible, this can be contrasted with the reasoning of the character of Tancredi, the nephew of Don Fabrizio in Giuseppe Tomasi di Lampedusa's Il Gattopardo. In the novel, Tancredi famously instigates his struggle with Garibaldi's The Thousand by arguing that "If we want everything to remain as it is, everything must change"; in order to maintain their superior position, they - the lions and leopards of the old world would have to unite with the hyenas in order to retain their control over society. ${ }^{252}$ In conclusion, it is by way of an inversion of the meaning of the Tancredian credo that I advocate viewing the liaison between education and the world, between continuity and political freedom. This is the politically sober way for us to face our "mutual relations" and "conditions of life". ${ }^{253}$

\footnotetext{
250 Richard Sandler, Mångfald eller enfald (Stockholm: Tiden, 1937), 152.

251 For a critique of meritocracy, see: Alan Fox, "Class and Equality", Socialist Commentary, May (1956): 11-13; Young 1961; Jo Littler, Against Meritocracy: Culture, Power and Myths of Mobility (London/New York, Routledge, 2018); Young 1961.

252 "Se vogliamo che tutto rimanga com'è, bisogna che tutto cambi”, Lampedusa 1969, 21.

253 “gegenseitigen Beziehungen”; "Lebensstellung”, Marx \& Engels 1977, 465.
} 



\section{Svensk sammanfattning}

Runt 1990 genomfördes ett antal reformer av det svenska skolväsendet vilka ofta beskrivs som ett uttryck för ett systemskifte inom svensk skolpolitik. Från att ha strukturerats av en strävan efter att uppnå en större jämlikhet, har utbildningssystemet sedan dess alltmer kommit att präglas av en strävan att utvidga individens valfrihet. Skolan i Sverige har härigenom, liksom samhället i övrigt, kommit att bli mer ojämlik.

\section{Syfte, frågeställningar och material}

Mot denna skolpolitiska bakgrund är syftet med föreliggande avhandling att analysera hur idén om jämlikhet som ett skolpolitiskt ideal har artikulerats utifrån ett historiskt-politiskt perspektiv under perioden 1946-2000. Med historiskt-politiskt perspektiv avser jag ett angreppssätt där fokus ligger på hur de sätt som jämlikhet har laddats temporalt, dvs. hur jämlikhetsidealet implicit eller explicit har relaterats till det förflutna, samtiden och framtiden. Angreppssättet är inspirerat av begreppet historicitetsregimer som utvecklats av den franske historikern François Hartog. Avhandlingens syfte är således att analysera hur idén om jämlikhet, analyserad som en politisktemporal kategori, har artikulerats i skolpolitiken under efterkrigstiden.

Det material som jag analyserar är företrädelsevis Sveriges offentliga utredningar och i något mindre utsträckning propositioner från i huvudsak period 1946-2000. För att avgränsa det övergripande problemet har jag valt att undersöka hur de sätt som lärare, den enskilda eleven samt undervisningsstoffet har artikulerats, kan förstås som olika politiskt-temporala uttryck för jämlikhet. Jag läser sålunda de analyserade dokumenten som uttryck för idéer i sin samtid. De skolpolitiska dokumenten analyseras alltså, givet skolans centrala ställning som institution för överförande av politiska ideal från en generation till nästa, som prismor genom vilka vi kan urskilja idéer som präglat samhället under olika tidsperioder. Undersökningen är en sammanläggningsavhandling indelad i fyra delstudier, där två är mer empiriskt orienterade och två syftar till att teoretiskt vidareutveckla resultaten från de empiriska artiklarna. 


\section{Angreppssätt}

Det tillämpade angreppssättet, att utvidga analysen genom att vidareutveckla de empiriska resultaten teoretiskt benämner jag ett vertikalt förhållningssätt. Idén om vertikalitet hänsyftar till två aspekter: dels den centrala roll som tillskrivs teoretiserande i avhandlingen, dels det diakrona angreppssättet. Syftet med att angripa problemet på detta vis är att jag har velat ta mig an det empiriska materialet utifrån ett begränsat antal teoretiska utgångspunkter, för att härigenom kunna genomföra en i större utsträckning intern kritik av det under efterkrigstiden artikulerade jämlikhetsidealet med de empiriska studierna som en grund för de följande teoretiska diskussionerna. Studien har således både historiska anspråk och syftar till att artikulera en, via det beskrivna historiskt-politiska angreppssättet, intern kritik av den uttalade strävan att demokratisera skolan under efterkrigstiden.

\section{Resultat}

Syftet sammanfaller i fyra stycken delstudier där jag undersöker fem forskningsfrågor. De två första studierna, (1) 'In Praise of the Present: The Pupil at Centre in Swedish Educational Politics in the Post-War Period' and (2) 'The Paradox of Democratic Equality: On the Modified Teacher Role in Post-War Sweden', undersöker jag empiriskt hur den enskilda eleven, läraren och innehållet i undervisningen framträder i materialet med avseende på den undersökta problematiken. I den första artikeln belyser jag hur idealet "att sätta eleven i centrum" förändras under perioden 1935-1992. I avhandlingens andra artikel är forskningsfrågan hur idén om vad en god lärare är förändrades under perioden, samt hur detta kan relateras till förändringar i synen på undervisningens ämnesinnehåll.

I de båda studierna visar jag hur det under efterkrigstiden sker en successiv förändring av det jämlikhetsideal som genomsyrar den uttalade ambitionen att skapa en demokratisk skola under efterkrigstiden. Jag visar hur idén om jämlikhet genomgår en förändring där den eftersträvade formen av jämlikhet initialt i första hand struktureras av framtiden, parallellt med att det förflutna alltjämt spelar en inte oväsentlig roll, under det att nuet från och med 1970-talet blir den alltmer framträdande strukturerande tidshorisonten. Mer specifikt visar jag hur jämlikhet, från att ha definierats som ett mål att sträva mot, från 1970-talet och framåt alltmer kommer att anta karaktären av ett mål att uppnå omedelbart i undervisningen. Detta kommer till uttryck bland annat $\mathrm{i}$ att idealet att sätta eleven i centrum initialt definieras som en strategi för att eleven ska kunna tillgodogöra sig mer av innehållet, men att idealet med tiden förskjuts mot att bli ett ideal att praktisera här och nu. 
I de båda studierna, i synnerhet den första, visar jag hur denna förändring kan relateras till Hartog's idé att den industrialiserade, kapitalistiska delen av världen under efterkrigstiden har gått från en framtidsorienterad historicitetsregim till en nutidsorienterad dito: en presentistisk historicitetsregim. Genom att framhålla hur dessa strukturella förändringar är sammanflätade med ett successivt förändrat sätt att förstå jämlikhet, påvisar jag tidigare förbisedda drag av kontinuitet i skolpolitiken mellan 1946 och 2000. I kontrast till tidigare forskning framhåller jag hur de manifesta förändringar som skedde kring 1990 också bör förstås som en förlängning av de politiska impulser som präglade skolan under perioden 1946-1989. Resultaten bidrar på vis till att nyansera bilden av ett tvärt systemskifte, där jämlikhet hastigt kom att ersättas av valfrihetsprincipen. Tvärtom bör, med avseende på den politisk-temporala dimensionen av jämlikhet som jag analyserar, snarare reformerna runt 1990 i vissa relevanta avseenden betraktas som en vidareutveckling och radikalisering av idéer med rötter längre tillbaka i tiden.

Jag argumenterar för att detta bör förstås som ett uttryck för en demokratisk paradox. Paradoxen består i att den strävan efter att skapa en mer jämlik och demokratisk skola, vilket var ett uttalat mål med efterkrigstidens skolpolitik, när de radikaliserades mot slutet av 1960-talet och framförallt 1970-talet bidrog till att successivt underminera grunden för kopplingen mellan demokrati som ett gemensamt politiskt projekt och utbildningssystemet. Genom att analysera jämlikhet som ett politiskt-temporalt problem i skolpolitiken frilägger jag drag av kontinuitet mellan de inkluderande och radikala jämlikhetsidéerna under 1970-talet och framåt, där individens emancipation från diverse olika begränsade samhälleliga strukturer, och den tydligt nyliberalt präglade så kallade högervågen från 1980-talet och framåt, varav skolreformerna runt 1990 anses vara ett uttryck. Som analytiskt instrument för att frilägga dessa drag av ideologisk kontinuitet mobiliserar jag det från Hannah Arendt lånade begreppet det sociala.

I avhandlingens två sista delstudier utvecklar jag de empiriska resultaten genom att vidareutveckla deras teoretiska implikationer. I den tredje artikeln besvarar jag frågan hur vi kan förstå relationen mellan den specifika formen av jämlikhet och individualism genom att aktivera den franske proto-sociologen och statsmannen Alexis de Tocquevilles reflektioner kring möjligheter och hot i det moderna samhället. Jag fokuserar i synnerhet på vad han refererar till som framväxten av en "imaginär" jämlikhet i det moderna samhället, och vars självklara utgångspunkt är individen. Det som gör Tocquevilles reflektioner särskilt relevant är att de, på ett anmärkningsvärt förutseende vis, adresserar problem som framträtt tydligt först under efterkrigstiden - och detta på ett sätt som inte på något entydigt sätt kan 
inordnas i det i Sverige implicita eller explicita höger-vänster raster genom vilket skolpolitikens omvandlingar ofta skildras.

Ur Tocquevilles reflektioner kring det framväxande demokratiska samhället, vilket han belyser genom sina iakttagelser under sin resa i Nordamerika, utformar jag fyra stycken mer principiella tendenser vilka därefter sätts i verket för att vidareutveckla resultaten från de empiriska studierna. Jag visar framförallt på hur den imaginära jämlikhet som jag menar snabbt växte sig starkare under efterkrigstiden har bidragit till att underminera den grund utifrån vilken vi kan motivera upprätthållandet av kvalitativa distinktioner i skolan. På så vis, argumenterar jag, är den ett effektfullt redskap för att hjälpa oss att förstå den alltmer tillbakaträngda rollen för ämnesinnehållet och den nya lärarroll som följde med detta. Utifrån de tocquevillska kategorierna menar jag att dessa förändringar ska förstås som ett bortvittrande av viljan och förmågan att på en samhällelig, kollektiv nivå konfrontera dess enskilda medlemmar med det annorlunda, det som avviker från individen och hennes intressen. Såväl betonandet av nuet och den nya handledande lärarroll som växer fram parallellt härmed vittnar om detta. Ett annat uttryck härför är nedtonandet av kvalitativa skillnader i de skolpolitiska dokumenten, och det alltmer starka betonandet av att möta eleverna med det konkreta och välbekanta. Samtliga av dessa förändringar menar jag kan förstås som uttryck för den imaginära form av jämlikhet som Tocqueville menade skulle växa sig allt starkare i samband med det moderna samhällets framväxt.

I den fjärde artikelns första del besvarar jag frågan hur den imaginära, individcentrerade formen av jämlikhet, mer specifikt, kan relateras till framväxten av en presentistisk historicitetsregim. Till skillnad från de empiriska artiklarna, där jag indikerar existensen av en sådan relation, syftar denna del av artikeln till att utveckla hur relationen kan förstås i ett vidare historisktpolitiskt perspektiv. Genom att relatera mina resultat till tidigare forskning rörande den ökade tidsacceleration och det växande fokuserandet på nuet, vilket relateras såväl till miljöproblemen som till den kapitalistiska ekonomins omvandlingar, argumenterar jag för att resultaten också måste förstås i ljuset av mer omfattande samhällsomvandlingar. Genom att kontrastera mina resultat med de mer strukturella omvandlingarna, framhåller jag även hur mina resultat pekar på hur den fördjupade strävan efter jämlikhet som en ideologisk kraft har bidragit till framväxten av ett alltmer nuorienterat förhållningssätt i skolan.

I artikelns andra del besvarar jag avhandlingens femte delfråga: hur kan Arendts reflektioner rörande relationen mellan utbildning och politik mobiliseras för att adressera den politiska-temporal apori som jag menar att det moderna, imaginära jämlikhetsbegreppet genererar. I ljuset av de politiska 
återvändsgränder som det urskilda jämlikhetsidealet såsom politiskt ideal ger upphov till, argumenterar jag för att Arendts begrepp "världen" och hennes tankar kring utbildning och jämlikhet erbjuder en fruktbar grund för att angripa problemet. Jag framhåller hur Arendts resonemang vilar på en alternativ politiskt-temporal logik, grundad i en politisk idé om jämlikhet i kontrast till den verksamma imaginära idén om jämlikhet.

I avhandlingens konkluderande och tredje kapitel utvidgar jag resonemanget och visar hur resultaten från de empiriska undersökningarna även kan relateras till annat skolpolitiskt policymaterial samt till studier inom närbesläktade fält. I avslutningskapitlets tredje del utvecklar jag arbetet som påbörjats i den fjärde artikeln genom en fördjupande analys av hur den politisk-temporala jämlikhetsparadoxen kan relateras till tidigare forskning inom framförallt politisk teori. Jag visar här hur de Arendt-inspirerade resonemangen i den fjärde artikeln relaterar till inflytelserika alternativa sätt att tänka kring jämlikhet samt rörande de historiskt-politiska villkoren för politisk frihet. Ett centralt problem som jag lyfter fram är hur den snäva framstegsidé, enligt vilken det nya just $i$ kraft av att vara nytt betraktas som något önskvärt, är något som vi som det moderna projektets arvtagare fortfarande brottas med, samt varför efterkrigstidens skolpolitiska förändringar måste förstås i detta ljus. Jag argumenterar, avslutningsvis, för att distinktionen mellan frigörelse och praktiserandet av frihet är av avgörande betydelse för att förstå de mer övergripande historisk-politiska problem som föreliggande studie griper in i. 



\section{Bibliography}

Albäck Öberg, Shirin, Thomas Bull, Ylva Hasselberg, \& Niklas Stenlås. "Professions Under Siege”, Statsvetenskaplig tidskrift 188.1 (2016): 93-126.

Alhadeff-Jones, Michel. Time and the Rhythms of Emancipatory Education (London/New York: Routledge, 2017).

Althusser, Louis. "Idéologie et appareils idéologiques d'État”, Pensée 151.3 (1970): 67-125.

Althusser, Louis. On Ideology (London: Verso, 2008).

Anderson, Elisabeth. "Fair Opportunity in Education: A Democratic Equality Approach”, Ethics 117.4 (2007): 595-622.

Andersson, Jenny, \& Kjell Östberg. Norstedts Sveriges historia 1965-2012 (Stockholm: Norstedts, 2013).

Andersson, Jenny. The Library and the Workshop: Social Democracy and Capitalism in the Knowledge Age (Stanford, CA: Stanford University Press, 2008).

Antman, Peter, Göran Greider, \& Tomas Lappalainen (eds.). Systemskifte: Fyra folkhemsdebatter (Stockholm: Carlsson, 1993).

Arendt, Hannah. “Thinking and Moral Considerations: A Lecture”, Social Research 38.3 (1971): 417-446.

Arendt, Hannah. Between Past and Future (London: Penguin, 2006a [1961]).

Arendt, Hannah. Crises of the Republic (San Diego/New York/London: Harcourt Brace \& Company, 1972).

Arendt, Hannah. The Human Condition (Chicago: University of Chicago Press, 1998 [1958]).

Arendt, Hannah. La politique a-t-elle encore un sens? (Paris: l'Herne, 2008).

Arendt, Hannah. Lectures on Kant's Political Philosophy (Chicago: University of Chicago Press, 1992).

Arendt, Hannah. Life of the Mind (San Diego/New York/London: Harcourt Inc., 1978).

Arendt, Hannah. Love and Saint Augustine (Chicago: University of Chicago Press, 1996 [1929]).

Arendt, Hannah. Men in Dark Times (USA: Stellar Classics, 2014).

Arendt, Hannah. On Revolution (London: Penguin Classics, 2006b [1963]).

Arendt, Hannah. Responsibility and Judgment (New York: Schocken Books, 2003). 


\section{The APORIA OF EqUALITY}

Arendt, Hannah. The Origins of Totalitarianism (New York: Schocken Books, 2004 [1951]).

Arendt, Hannah. The Promise of Politics (New York: Schocken Books, 2007).

Arendt, Hannah. Thinking Without a Bannister: Essays in Understanding (New York: Schocken Books, 2018).

Aristotle. Politics (Indianapolis: Hackett Publishing Company, 1998).

Aron, Raymond. Dix-huit leçons de la société industrielle (Paris: Gallimard, 1962).

Aron, Raymond. Essai sur les libertés (Paris: Pluriel, 2015).

Aron, Raymond. La lutte de classes: nouvelles leçons sur les sociétés industrielles (Paris, Idées NRF, 1964).

Aron, Raymond. Progress and Disillusion: The Dialectics of Modern Society (New York: Praeger, 1968).

Audier, Serge. Tocqueville retrouvé: genèse et enjeux du renouveau tocquevillien français (Paris: Vrin, 2004).

Baggesen Klitgaard, Michael. "Do Welfare State Regimes Determine Public Sector Reforms? Choice Reforms in American, Swedish and German Schools”, Scandinavian Political Studies 30.4 (2007): 444-468.

Balibar, Étienne. "Ambiguous Universality”, Differences: A Journal of Feminist Cultural Studies 7.1 (1995): 146-175.

Balibar, Étienne. La préposition d'égaliberté (Paris: PUF, 2010).

Bauman, Zygmunt. The Individualized Society (Cambridge: Polity Press, 2001).

Beck-Gernsheim, Elisabeth, \& Ulrich Beck. Individualization (London: Sage, 2001). Becker, Gary. "The Economic Way of Looking at Life”, December 9, 1992: www.nobelprize.org/nobel_prizes/economic-sciences/laureates/1992/beckerlecture.pdf.

Bell, Daniel. The Cultural Contradictions of Capitalism (London: Heinemann, 1976).

Benhabib, Seyla. The Reluctant Modernism of Hannah Arendt (London/New Delhi: Sage Publications, 1996).

Benjamin, Walter. Illuminations: Essays and Reflections (New York: Schocken Books, 1999).

Bennett, Tony, Lawrence Grossberg, \& Meaghan Morris. New Keywords: A Revised Vocabulary of Culture and Society (London: Blackwell Publishing Ltd., 2005).

Bergdahl, Lovisa, \& Elisabeth Langmann, “'Where are You?’ Giving Voice to the Teacher by Reclaiming the Private/Public Distinction”, Journal of Philosophy of Education 51.2 (2017): 461-475.

Berggren, Henrik, \& Lars Trädgårdh. Är svensken en människa (Stockholm: Norstedts, 2014).

Bergström, Göran. Jämlikhet och kunskap: Debatter om reformstrategier i socialdemokratisk skolpolitik 1975-1990 (Stockholm: Symposium Graduale, 1993).

Berman, Marshall. All That is Solid Melts Into Air (London: Verso, 1983). 


\section{BIBLIOGRAPHY}

Bernstein, Richard J. Why Read Hannah Arendt Now? (Cambridge: Polity Press, 2018).

Bernstein, Richard J. Beyond Objectivism and Relativism: Science, Hermeneutics, and Praxis (Philadelphia: University of Pennsylvania Press, 1983).

Bertilsson, Emil. Skollärare: Rekrytering till utbildning och yrke 1977-2009(Uppsala: ILU, Uppsala universitet, 2014).

Biesta, Gert. "Against Learning: Reclaiming a Language for Education in an Age of Learning”. Nordic Studies in Education 25.1 (2005): 54-66.

Biesta, Gert. "How to Exist Politically and Learn from It: Hannah Arendt and the Problem of Democratic Education”, Teachers College Record 112 (2010): 665-575.

Biesta, Gert. Bortom lärandet: Demokratisk utbildning för en mänsklig framtid (Lund: Studentlitteratur, 2006).

Bildt, Carl. Declaration of Government, Riksdagens protokoll 1991/92:6.

Bjereld, Ulf, \& Marie Demker. I vattumannens tid? (Stockholm: Hjalmarsson \& Högberg bokförlag, 2005).

Björklund, Anders, Melissa A. Clark, Per-Anders Edin, Peter Fredriksson, \& Alan B. Krueger (eds.). The Market Comes to Education in Sweden: An Evaluation of Sweden's Surprising School Reforms (New York: Russell Sage Foundation, 2005).

Blais, Marie-Claude, Marcel Gauchet, \& Dominique Ottavi. Conditions de l'éducation (Paris: Pluriel, 2010).

Bloch, Ernst. "Nonsynchronism and the Obligation to Its Dialectics", New German Critique 11 (1977): 22-38.

Boltanski, Luc. "The Left After May 1968 and the Longing for Total Revolution”, Thesis Eleven 69.1 (2002): 1-20.

Boman, Ylva. Utbildningspolitik $i$ det andra moderna: om skolans normativa villkor (Örebro: Örebro universitet, 2002).

Bonneuil, Christophe, \& Jean-Baptiste Fressoz. L'évènement Anthopocène, la Terre, l'histoire et nous (Paris: Seuil, 2013).

Boréus, Kristina. Högervåg: Nyliberalismen och kampen om språket 1969-1989

(Stockholm: Tiden, 1994).

Bourdieu, Pierre. Outline of a Theory of Practice (Cambridge: Cambridge University Press, 1977).

Bouton, Christoph. Le temps de l'urgence (Lormont: Le bord de l'eau, 2013).

Brahami, Frédéric. La Raison du peuple (Paris: Les Belles Lettres, 2016).

Braun, Kathrin. "Biopolitics and Temporality in Arendt and Foucault", Time \& Society 16.1 (2007): 5-23.

Brighouse, Harry, \& Adam Swifts. "Equality, Priority and Positional Goods", Ethics 116.3 (2006): 471-497.

Broady, Donald, Mikael Börjesson, \& Emil Bertilsson. “Temaintroduktion: Lärarutbildningens hierarkier”, Praktiske Grunde 4 (2009): 7-18. 


\section{THE APORIA OF EQUALITY}

Broady, Donald. "Det svenska hos ramfaktorteorin”, Pedagogisk forskning i Sverige 4.1 (1999): 111-121.

Buckler, Steve. Hannah Arendt and Political Theory: Challenging the Tradition (Edinburgh: Edinburgh University Press, 2011).

Buhre, Frida. "Hannah Arendt och framtidens dilemma”, Fronesis 52-53 (2015): 210-220.

Buhre, Frida. Speaking the Anachronisms: Arendt, Politics, Temporality (Uppsala: University of Uppsala, 2015).

Bunar, Nihad. "Choosing for Quality or Inequality: Current Perspectives on the Implementation of School Choice Policy in Sweden”, Journal of Education Policy 25.1 (2010): 1-18.

Börjesson, Mattias. Från likvärdighet till marknad: En studie av offentligt och privat inflytande över skolans styrning $i$ svensk utbildningspolitik 1969-1999 (Örebro: Örebro universitet, 2016).

Börjesson, Mikael, \& Donald Broady. Det svenska högskolefältet och lärarutbildningarna (Uppsala: ILU, Uppsala, 2006).

Cabet, Étienne. Voyage en Icarie (Paris, 1846).

Callewaert, Staf \& Daniel Kallós. "Den rosa vågen i svensk pedagogik”, in Staffan Selander (ed.), Forskning om utbildning: An antologi (Stockholm: Brutus Östlings Bokförlag, 1992).

Canovan, Margaret. Hannah Arendt: A Reinterpretation of Her Political Thought (Cambridge: Cambridge University Press, 1992).

Carlbaum, Sara. Blir du lönsam lille vän (Umeå: Umeå universitet, 2012).

Carleheden, Mikael. "What conception of the theoretical does 'theorizing' presuppose? Comment on Richard Swedberg's 'Before theory comes theorizing or how to make social science more interesting”, The British Journal of Sociology 67.1 (2016): 36-42.

Carnevali, Barbara. "Contro la Theory. Una provocazione”, www.leparoleelecose.it/?p=24320.

Castoriadis, Cornelius. "Pouvoir, politique, autonomie", in Le monde morcelé: Les carrefours du labyrinthe (Paris: Point Essais, 2000).

Castoriadis, Cornelius. Figures du pensable: Les carrefours du labyrinthe 6 (Paris: Éditions de Seuil, 1999).

Castoriadis, Cornelius. La montée de l'insignifiance (Paris: Éditions de Seuil, 1996).

Castoriadis, Cornelius. Le monde morcelé: les carrefours du labyrinthe 3 (Paris: Éditions de Seuil, 2000).

Cohen, Gerald Allan. If Tou're an Egalitarian, How Come You're So Rich? (Cambridge, MA: Harvard University Press, 2001). 


\section{BIBLIOGRAPHY}

Colla, Piero, \& Tomas Wedin. "De la planification à la liberté de choix: une révolution pour le modèle éducatif suédois? Conversation avec Ulf $\mathrm{P}$. Lundgren", Nordiques (forthcoming).

Colla, Piero. L'héritage impossible: Conscience historique et technologies de l'identité dans la réforme éducative en Suède 1946-1980(Paris: EHESS, 2017).

Collingwood, Robin George. An Autobiography (Oxford: Oxford University Press, 1939).

Connolley, Steven, \& Rune Sarromaa Hausstätter. “Tocqueville on Democracy and Inclusive Education: A More Ardent and Enduring Love of Equality than of Liberty”, European Journal of Special Needs Education 24.3 (2009): 231-243.

Crisp, Roger. "Equality, Priority, and Compassion”, Ethics 113.4 (2003): 745-763.

Dahlstedt, Magnus, \& Fredrik Hertzberg. "Den entreprenörskapande skolan: Styrning, subjektsskapande och entreprenörskapspedagogik”, Pedagogisk forskning $i$ Sverige 16.3 (2011): 179-198.

Dahlstedt, Magnus. "I val(o)frihetens spar: Segregation, differentiering och två decennier av skolreformer”, Pedagogisk Forskning $i$ Sverige 12:1 (2007): 20-38.

Dahlstedt, Magnus. "The Swedish Road to Democracy? Governmentality, Technologies of Citizenship and Popular Movements", ThemES - Themes on Migration and Ethnic Studies 30 (2009).

Danoff, Brian. "A School or a Stage? Tocqueville and Arendt on Politics and Education", Perspectives on Political Science 41.3 (2012): 117-124.

Degerman, Dan. "Within the Heart's Darkness: The Role of Emotions in Arendt's Political Thought”, European Journal of Political Theory (2016): 1-21.

Deleuze, Gilles. "Post-scriptum sur les sociétés de contrôle”, L’autre journal 1 (1999).

Dellnäs, Ann-Christine. Om ekonomisk imperialism - En studie av Gary S. Beckers idéer om humankapital, familj och kriminalitet (Göteborg: Institutionen för idéhistoria och vetenskapsteori, Göteborgs universitet, 2002).

Demiryol, Gaye Ilhan. "Arendt and Benjamin: Tradition, Progress and the Break with the Past”, Journal of the Philosophy of History 12 (2018): 142-163.

Dewey, John. Democracy and Education (New York: The MacMillan Group, 1916).

Droysen, Johann Gustav. Outline of the Principles of History (Australia: Leopold Classic Library, 2015 [1893]).

Dumont, Louis. Homo aequalis I (Paris: Gallimard, 2008).

Dumont, Louis. Essais sur l'individualisme (Paris: Éditions de Seuil, 1991).

Dumont, Louis. Homo hierarchicus (Paris: Gallimard, 1992).

Durkheim, Émile. Sociologie et philosophie (Paris: PUF, 2014 [1924]).

Dworkin, Gerald. The Theory and Practice of Autonomy (Cambridge: Cambridge University Press, 1988). 


\section{The APORIA OF EQUALITY}

Dworkin, Ronald. "What is Equality? Part 1: Equality of Welfare”, Philosophy \&" Public Affairs 10.3 (1981): 185-246.

Dworkin, Ronald. "What is Equality? Part 2: Equality of Resources", Philosophy \&" Public Affairs 10.4 (1981): 283-345.

Eagleton, Terry. Ideology: An Introduction (London: Verso, 2007).

Eagleton, Terry. The Idea of Culture (Oxford: Blackwell, 2000).

Ecclestone, Kathryn, \& Dennis Hayes. The Dangerous Rise of Therapeutic Education (London: Routledge, 2009).

Ecclestone, Kathryn. "Resisting Images of the 'Diminished Self: The Implications of Emotional Wellbeing and Emotional Engagement in Education Policy”, Journal of Education Policy 22.4 (2007): 455-470.

Ehnmark, Anders. Slottet: En essä om Tocqueville (Stockholm: Norstedt, 1990).

Eliot, Thomas Stearns. On Poetry and Poets (New York: Farrar, Straus and Giroux, 2009).

Englund, Tomas (ed.). Utbildningspolitiskt systemskifte? (Stockholm: HLS, 1996).

Englund, Tomas, \& Ann Quennerstedt (eds.). Vadå likvärdighet (Daidalos: Göteborg, 2008).

Englund, Tomas. "Education as a Citizenship Right - a Concept in Transition: Sweden Related to Other Western Democracies and Political Philosophies”, Journal of Curriculum Studies 26.4 (1994): 383-399.

Englund, Tomas. “Utbildning som 'public good' eller 'private good'?”, in Tomas Englund (ed.), Utbildningspolitiskt systemskifte? (Stockholm: HLS Förlag, 1996).

Englund, Tomas. Läroplanens och skolkunskapens politiska dimension (Göteborg: Daidalos, 2005).

Enkvist, Inger. Feltänkt (Stockholm: SNS Förlag, 2000).

Erlander, Tage. 1940-1949 (Stockholm: Tidens Förlag, 1973).

Erman, Eva, \& Niklas Möller. "Practices and Principles: On the Methodological Turn in Political Theory”, Philosophy Compass 10.8 (2015): 533-546.

Fareld, Victoria. "Contexts in Flux: Textual Concerns for the Historian of Ideas", Ideas in History 2.3 (2007a).

Fareld, Victoria. “Tideologi: De politiska idéernas tidslighet”, Fronesis 52-53 (2015): 172-178.

Fareld, Victoria. Att vara inom sig utom sig (Göteborg: Glänta, 2007b).

Fejes, Andreas, \& Magnus Dahlstedt. Skolan, marknaden och framtiden (Lund: Studentlitteratur, 2018).

Fernández, Christian. "Liberaliseringen av svensk skolpolitik", Statsvetenskaplig tidskrift 114.2 (2012): 241-269. 


\section{BIBLIOGRAPHY}

Floyd, Jonathan, \& Marc Stears (eds.). Political Philosophy Versus History? Contextualism and Real Politics in Contemporary Political Thought (Cambridge: Cambridge University Press, 2011).

Foray, Philippe. "Hannah Arendt, l'éducation et la question du monde", Le Télémaque 1.19 (2001): 79-101.

Fornäs, Johan. Defending Culture: Conceptual Foundations and Contemporary Debate (London: Palgrave Macmillan, 2017).

Foucault, Michel. La naissance de la biopolitique (Paris: Gallimard, 2004).

Foucault, Michel. Sécurité, territoire, population (Paris: Gallimard, 2004).

Fox, Alan. "Class and Equality”, Socialist Commentary May (1956): 11-13.

Fraser, Nancy. "Can Society be Commodities All the Way Down? Post-Polanyian Reflections on Capitalist Crisis”, Economy and Society 43.4 (2014): 541-558.

Fraser, Nancy. "Social Justice in the Age of Identity Politics: Redistribution, Recognition, and Participation", The Tanner Lectures on Human Values, delivered at Stanford University, April 30-May 2, 1996.

Fredriksson, Anders. Marknaden och lärarna: Hur organiseringen av skolan påverkar lärares offentliga tjänstemannaskap (Göteborg: Göteborg Studies in Politics, 2010).

Frenander, Anders. Debattens vågor: Om politisk-ideologiska i efterkrigstidens svenska kulturdebatt (Göteborg: Göteborgs universitet, 1998).

Frenander, Anders. Kulturen som kulturpolitikens stora problem: Diskussionen om svensk kulturpolitik under 1900-talet (Hedemora: Gidlunds Förlag, 2005).

Friedman, Milton. "The Role of Government in Education”, in Robert A. Solo (ed.), Economics and the Public Interest (New Brunswick, NJ: Rutgers University Press, $1955)$.

Frost Benedikt, Amélie. "Doing the Right Thing at the Right Time: Toward and Ethics of Kairos”, in Phillip Sipiora \& James S. Baumlin (eds.), Rhetoric and Kairos: Essays in History, Theory and Praxis (Albany: State University of New York Press, 2002).

Frykman, Jonas. Ljusnande framtid (Lund: Historiska Media, 2014).

Furedi, Frank. Therapy Culture: Cultivating Vulnerability in an Uncertain Age (London: Routledge, 2004).

Furedi, Frank. Wasted: Why Education isn't Educating (London: Continuum, 2009).

Gadamer, Hans-Georg. Truth and Method (London/New York: Continuum, 2006). Gadamer, Hans-Georg. The Enigma of Health: The Art of Healing in a Scientific Age (Stanford, CA: Stanford University Press, 1996).

Gauchet, Marcel. "Les droits de l'homme ne sont pas une politique", Le débat 3 (1980): 3-21.

Gauchet, Marcel. "Quand les droits de l'homme deviennent une politique”, La démocratie contre elle-même (Paris: Gallimard, 2002). 


\section{The APORIA OF EqUALITY}

Gauchet, Marcel. l'Avènement de la démocratie IV: Le nouveau monde (Paris: Gallimard, 2017).

Gauchet, Marcel. La condition politique (Paris: Gallimard, 2005).

Gauchet, Marcel. La démocratie contre elle-même (Paris: Gallimard, 2002).

Geuss, Raymond. The Idea of a Critical Theory (Cambridge: Cambridge University Press, 1981).

Giota, Joanna. "Individualiserad undervisning i skolan: En forskningsöversikt”, Vetenskapsrådets rapportserie (Stockholm: Vetenskapsrådet, 2013).

Government Bill 1950:70, Angående riktlinjer för det svenska skolväsendets utveckling.

Government bill 1954:209, Angående inrättande av en första lärarhögskola

Government Bill 1975/76:39, Om skolans inre arbete m.m.

Government Bill 1984/85:122, Om lärarutbildning för grundskolan m.m.

Government Bill 1995/96:206, Vissa skolfrågor m.m.

Government Bill 1999/2000:135, En förnyad lärarutbildning.

Government Bill 2008:109, En hållbar lärarutbildning.

Gumbrecht, Hans Ulrich. Our Broad Present (New York: Columbia University Press, 2014).

Gustavsson, Jan-Erik, Sverker Sörlin, \& Jonas Vlachos. Policyidéer för svensk skola (Stockholm: SNS Förlag, 2016).

Gutmann, Amy. Democratic Education (Princeton: Princeton University Press, 1987).

Hadenius, Karin. Jämlikhet och frihet: Politiska mål för den svenska grundskolan (Stockholm: Almqvist \& Wiksell, 1990).

Hansen, Phillip. Hannah Arendt: Politics, History and Citizenship (Cambridge: Polity Press, 2007).

Hartog, François. "Vers une nouvelle condition historique", Le Débat 1.188 (2016): 169-180.

Hartog, François. Régimes d'historicité: Présentisme et expérience du temps (Paris: Seuil, 2012).

Harvey, David. A Brief History of Neoliberalism (Oxford: Oxford University Press, 2005).

Harvey, David. The Condition of Postmodernity: An Inquiry into the Origins of Cultural Change (Oxford: Wiley-Blackwell, 1991).

Hassan, Robert. Empires of Speed: Time and Acceleration of Politics and Society (Leiden: Brill, 2009).

Hasselberg, Ylva. Vem vill leva i kunskapssamhället? Essäer om universitetet och samtiden (Hedemora: Gidlunds, 2009).

Hermann Lübbe. Im Zug der Zeit: Verkürzter Aufenthalt in der Gegenwart (Berlin: Springer, 1992). 


\section{BIBLIOGRAPHY}

Hill, Melvyn A. (ed.). Hannah Arendt: The Recovery of the Public World (New York: St. Martin's Press, 1979).

Holmqvist, Mikael. Djursholm: Sveriges ledarsamhälle (Stockholm: Atlantis, 2015). Hooghe, Liesbet, Gary Marks, \& Carole J. Wilsons, "Does Left/Right Structure Party Positions on European Integration”, Comparative Political Studies 35.8 (2002): 965-989.

Hunt, Lynn. Inventing Human Rights (New York: W.W. Norton, 2008).

Illouz, Eva. Cold Intimacies: The Making of Emotional Capitalism (Cambridge: Polity, 2007).

Inglehart, Ronald. Culture Shift in Advanced Industrial Society (Princeton: Princeton University Press, 1990).

Irisdotter Aldenmyr, Sara. "Moral Aspects of Therapeutic Education: A Case Study of Life Competence Education in Swedish Education”, Journal of Moral

Education 41.1 (2012): 23-37.

Isling, Åke. Kampen för och emot en demokratisk skola (Stockholm: Sober Förlag 1980).

Ivarsson, Anders, Ylva Waldemarsson, \& Kjell Östberg (eds.). Det långa 1990-talet: När Sverige förändrades (Umeå: Boréa, 2014).

Jameson, Fredric. "Postmodernism: The Cultural Logic of late Capitalism”, New Left Review 146 (1984): 53-92.

Jameson, Fredric. "The Politics of Theory: Ideological Positions in the Postmodernism Debate", New German Critique 33 (1984): 53-65.

Jameson, Fredric. Postmodernism, or, The Cultural Logic of Late Capitalism (London/New York: Verso, 1992).

Jameson, Fredric. The Cultural Turn: Selected Writings on the Postmodern 1983-1998 (London: Verso, 2009).

Jameson, Fredric. The Hegel Variations: On the Phenomenology of Spirit (London/New York: Verso, 2010).

Jameson, Fredric. The Political Unconscious: Narrative as a Socially Symbolic Act (London: Routledge, 2002).

Jankélévitch, Vladimir. L'Alternative (Paris: Alcan, 1938).

Jarl, Maria, \& Linda Rönnberg. Skolpolitik: Från riksdagshuset till klassrum (Stockholm: Liber, 2010).

Jarl, Maria. Skolan och det kommunala huvudmannaskapet (Malmö: Gleerups, 2012).

Johanson, Jan. Det statliga kommittéväsendet. Kunskap-kontroll-konsensus (Stockholm:

Statsvetenskapliga institutionen Stockholms universitet, 1992).

Johansson, Alf W. Herbert Tingsten och det kalla kriget: Antikommunism och liberalism $i$ Dagens Nyheter 1946 (Stockholm: Tiden, 1995).

Jordheim, Helge. “Against Periodization”, History and Theory 51 (2012): 151-171. 


\section{The APORIA OF EqUALITY}

Jordheim, Helge. "Historiemedvetande, tidsregimer och synkronisering", in Victoria Fareld \& Hans Ruin (eds.), Historiens hemvist 1: den historiska tidens former (Stockholm: Makadam Förlag, 2016).

Kallós, Daniel. Den nya pedagogiken: En analys av den s $k$ dialogpedagogiken som svenskt samhällsfenomen (Stockholm: Wahlström \& Widstrand, 1979).

Karlsohn, Thomas. "On Emotions, Knowledge and Educational Institutions”, Confero 4.1 (2016): 137-164.

Karlsohn, Thomas. "Vad ska en svensk kunna? Om emotioner, kunskaper och institutioner”, in Michael Gustavsson, Tove Österman, \& Elinor Hållén (eds.), Vad ska en svensk kunna? (Göteborg: Daidalos, 2016).

Karlsohn, Thomas. Teknik, Retorik, Kritik: om IT-bubblan och datoriseringen av den svenska skolan (Stockholm: Carlsson Bokförlag, 2009).

Kateb, George. "Political Action: Its Nature and Advantages", in Dana Villa (ed.), The Cambridge Companion to Hannah Arendt (Cambridge: Cambridge University Press, 2002).

Kateb, George. Hannah Arendt: Politics, Conscience, Evil (Oxford: Rowman \& Allanheld, 1984).

Kattago, Siobhan. "Hannah Arendt on the World”, in Patrick Hayden (ed.), Hannah Arendt: Key Concepts (London: Routledge, 2014).

Klockar Linder, My. Kulturpolitik: Formeringen av en modern kategori (Uppsala: Uppsala universitet, 2014).

Klockar Linder, My. När kultur var i rörelse: kulturbegreppets förändring under sextiotalet, speglad genom tidskriften OrdङBild (unpublished Master's thesis, Södertörn, 2006).

Kohn, Jerome. "Freedom: The Priority of the Political", in Dana Villa (ed.), The Cambridge Companion to Hannah Arendt (Cambridge: Cambridge University Press, 2002).

Koselleck, Reinhart. "The Temporalisation of Utopia”, in The Practice of Conceptual History: Timing History, Spacing Concepts (Stanford, CA: Stanford University Press, 2002).

Koselleck, Reinhart. Erfarenhet, tid och historia (Göteborg: Daidalos, 2004).

Koselleck, Reinhart. Futures Past: On the Semantics of Historical Time (Cambridge, MA: MIT Press, 1985).

Koselleck, Reinhart. Zeitschichten. Studien zur Historik (Frankfurt: Suhrkamp, 2000). Kymlicka, Will. Contemporary Political Philosophy: An Introduction (Oxford: Oxford University Press, 2002).

Källström, Staffan. Den gode nihilisten (Stockholm: Raben \& Sjögren, 1986).

Laborde, Cecile, \& John Maynor. Republicanism Political Theory (Hoboken: WileyBlackwell, 2008). 


\section{BIBLIOGRAPHY}

Lampedusa, Giuseppe Tommasi di. Il Gattopardo (Rome: Feltrinelli editore, 1969).

Landahl, Joakim. "Skolämnen och moralisk fostran: En komparativ studie av samhällskunskap och livskunskap”, Nordic Journal of Educational History 2.2 (2015): 27-47.

Landahl, Joakim. Auktoritet och ansvar: Lärares fostrans- och omsorgsarbete $i$ historisk belysning (Stockholm: Arbetslivsinstitutet, 2006).

Landahl, Joakim. Politik \& pedagogik: En biografi över Fridtjuv Berg (Stockholm: Lärarstiftelsen, 2016).

Larsson, Hans Albin. Skola eller kommunal ungdomsomsorg? Om att försöka skapa en jämlik och demokratisk skola (Stockholm: SNS Förlag, 2002).

Larsson, Hans-Albin. Mot bättre vetande: En svensk skolhistoria (Stockholm: SNS Förlag, 2011).

Lasch, Christopher. “The Communitarian Critique of Liberalism”, Soundings: An Interdisciplinary Journal 69.1-2 (1986): 60-76.

Lasch, Christopher. The Culture of Narcissism (New York: W.W. Norton, 1979).

Leffler, Eva. Företagsamma elever: Diskurser kring entreprenörskap och företagsamhet $i$ skolan (Umeå: Umeå universitet, 2006).

Liedman, Sven-Eric, \& Ingmar Nilsson. Om ideologi och ideologianalys: Uppsatser och texter (Göteborg: Institutionen för idé- och lärdomshistoria, 1989).

Liedman, Sven-Eric. "Marknaden och viljan att mäta”, in Magnus Dahlstedt \& Andreas Fejes (eds.), Skolan, marknaden och framtiden (Lund: Studentlitteratur, 2018).

Liedman, Sven-Eric. Surdeg (Stockholm: Författarförlaget, 1980).

Lindensjö, Bo, \& Ulf P. Lundgren. Utbildningsreformer och politisk styrning (Stockholm: Liber, 2014).

Linderoth, Jonas. Lärarens återkomst: Från förvirring till upprättelse (Stockholm: Natur \& kultur, 2016).

Littler, Jo. Against Meritocracy: Culture, Power and Myths of Mobility (London/New York: Routledge, 2018).

Lloyd, Margie. “In Tocqueville’s Shadow: Hannah Arendt's Liberal Republicanism”, The Review of Politics 57.1 (1995): 31-58.

Lorentzen, Håkon. Felleskapets fundament (Oslo: Pax, 2004).

Lundahl, Lisbeth. "Decentralisation, Deregulation, Quasi-markets - and then what?”, Journal of Education Policy 17.6 (2002): 687-697.

Lundgren, Ulf P. "Utbildningspolitik och utbildningskoder: Förändringar i svensk utbildningspolitik”, Jesper E. Larsen, Börge Riis Larsen, \& Susanne Wiborg (eds.), Arbog 2006: Velfaerdsstaten under pres (Köpenhamn: Selskabet for skole- og uddannelsehistorie, 2006).

Lübbe, Hermann. Im Zug der Zeit: Verkürzter Aufenthalt in der Gegenwart (Berlin: Springer, 1992). 


\section{THE APORIA OF EQUALITY}

Lübbe, Hermann. "The Contraction of the Present", in Hartmut Rosa and William E. Scheuerman (eds.), High-Speed Society: Social Acceleration, Power and Modernity (Pennsylvania: Penn State University Press, 2009).

Lyotard, François. "Les problèmes du savoir dans les sociétés industrielles les plus développées", Offentlig rapport för universitetsrådet (Québec, 1979).

Läroplan för grundskolan 1962 (Stockholm, 1962).

Läroplan for grundskolan 1969 (Stockholm, 1969).

Läroplan för grundskolan 1980 (Stockholm, 1980).

Läroplan för grundskolan 1994 (Stockholm, 1994).

MacIntyre, Alasdair. After Virtue: A Study in Moral Theory (London/New York: Bloomsbury, 2016).

Manent, Pierre. Cours familiers de la philosophie politique (Paris: Gallimard, 2001).

Manent, Pierre. Enquête sur la démocratie (Paris: Gallimard, 2007).

Manent, Pierre. La raison des nations (Paris: Gallimard, 2006).

Manent, Pierre. Le regard politique (Paris: Flammarion, 2010).

Manent, Pierre. Tocqueville et la nature de la démocratie (Paris: Gallimard, 2012)

Marklund, Sixten. Vår skola: Historik, reformverksamhet, dagens utbildningssystem, utvecklingstendenser (Stockholm: Bonniers, 1974).

Marx, Karl, \& Friedrich Engels. "Manifest der Kommunistischen Partei” (last version from 1890), in Marx-Engels Werke, Band 4 (Berlin: Dietz Verlag, 1977).

Marx, Karl, \& Friedrich Engels. The Communist Manifesto (Oxford: Oxford University Press, 2008 [1848]).

Marx, Karl. "Zur Judenfrage”, in Werke Band 1 (Berlin: Dietz Verlag, 1981 [1843]).

Marx, Karl. Capital, Volume 1 (London: Penguin Classics, 1990 [1867]).

Masschelein, Jan, \& Maarten Simons. In Defence of the School: A Public Issue (Leuven: Education, Culture \& Society Publishers, 2013).

McCulloch, Gary. Philosophers and Kings: Education for Leadership in Modern England (Cambridge: Cambridge University Press, 1991).

McKerlie, Dennis. "Equality and Time”, Ethics 99.3 (1989): 475-491.

Milbank, John, \& Adrian Pabst. The Politics of Virtue: Post-liberalism and the Human Future (London: Rowman \& Littlefield, 2016).

Milbank, John. "Against Human Rights: Liberty in the Western Tradition”, Oxford Journal of Law and Religion 1.1 (2012): 203-234.

Milbank, John. "Culture and Justice", Theory, Culture \& Society 27.6 (2010): 107-124.

Milbank, John. Theology and Social Theory: Beyond Secular Reason (Oxford: Wiley \& Blackwell, 2006).

Millares, Matilde. Att välja välfärd: Politiska berättelser om valfrihet (Stockholm: Stockholms universitet, 2015).

Montesquieu, Charles Louis de Secondat. L'esprit des lois 1 (Paris: Flammarion, $1986[1748])$. 


\section{BIBLIOGRAPHY}

Mouffe, Chantal, \& Ernesto Laclau. Hegemony and Socialist Strategy: Towards a Radical Democratic Politics (London: Verso, 1985).

Mückenberger, Ulrich. "Social Integration or Anomie? The Welfare State Challenged by Individualism”, in John Ferris \& Robert Page (eds.), Social Policy in Transition: Anglo-German Perspectives in the New European Community (Aldershot: Avebury, 1996).

Nerman, Bengt. Demokratins kultursyn (Stockholm: Albert Bonniers Förlag, 1962).

Nietzsche, Friedrich. "Twilight of the Idols" [1889], in Aaron Ridley \& Judith Norman (eds.), The Anti-Christ, Ecce Homo, Twilight of the Idols, and Other Writings (Cambridge: Cambridge University Press, 2006).

Nietzsche, Friedrich. Otidsenliga betraktelser (Stockholm: Symposium, 2005 [187376]).

Nora, Pierre. "Between Memory and History: Les Lieux de Mémoire", Representations 26 (1989): 7-24.

Nora, Pierre. Lieux des mémoires: La République; La Nation; Les France (Paris: Gallimard, 1984; 1986; 1992).

Nykänen, Pia. Värdegrund, demokrati och tolerans: Om skolans fostran i ett mångkulturellt samhälle (Stockholm: Thales, 2009).

Oakeshott, Michael. On History (Indianapolis: Liberty Fund, 1999).

Olofsdotter Stensöta, Helena. "Det empatiska staten”, Ord£'Bild 3-4 (2006): 46-55.

Olsson, Ulf. Folkhälsa som pedagogiskt projekt: Bilden av hälsoupplysning $i$ statens offentliga utredningar (Uppsala: Uppsala universitet, 1997).

Osborne, Peter. The Politics of Time: Modernity and Avant-Garde (London: Verso, 1995).

Passerin d'Entrèves, Maurizio. The Political Philosophy of Hannah Arendt (London/New York: Routledge, 1994).

Persson, Ingmar. "Equality, Priority and Person-Affecting Value”, Ethical Theory and Moral Practice 4.1 (2001): 23-39.

Persson, Sofia. Läraryrkets uppkomst och förändring: en sociologisk studie av lärares villkor, organisering och yrkesprojekt inom den grundläggande utbildningen ca 18002000 (Göteborg: Department of Sociology, University of Gotheburg, 2008).

Petterson, Lars. Frihet, jämlikhet, egendom och Bentham: Utvecklingslinjer $i$ svensk folkundervisning mellan feodalism och kapitalism 1809-1860 (Uppsala: Studia historica Upsaliensia, 1992).

Pettit, Philip. Republicanism: A Theory of Freedom and Government (Oxford: Oxford University Press, 2010).

Pitkin, Hannah Fenichel. The Attack of the Blob: Hannah Arendt's Concept of the Social (Chicago: University of Chicago Press, 1998). 


\section{The APORIA OF EqUALITY}

Pomian, Krzysztof. “Partir du présent”, Le débat, 175.3 (2013): 79-92.

Rancière, Jacques. "Who Is the Subject of the Rights of Man?", The South Atlantic Quarterly 103.2/3 (2004): 297-310.

Rancière, Jacques. Hatred of Democracy (London: Verso, 2009).

Rawls, John. A Theory of Justice (Cambridge, MA: Belknap Press, 1971).

Rawls, John. Justice as Fairness; A Restatement (Cambridge, MA: Belknap Press, 2002).

Reinhardt, Mark. The Art of Being Free (New York: Cornell University Press, 1997).

Richardson, Gunnar. Drömmen om en ny skola (Stockholm: Liber/Allmänna förlaget, 1983).

Richardson, Gunnar. Svensk utbildningshistoria: Skola och samhälle förr och nu (Lund: Studentlitteratur, 2010).

Ricoeur, Paul. Soi-même comme un autre (Paris: Points, 2015).

Rieff, Philip. The Triumph of the Therapeutic: Uses of Faith After Freud (New York: Harper \& Row, 1966).

Ringarp, Johanna. "Utbildningspolitiken - från kommunaliseringen till PISA", in Anders Ivarsson Westerberg, Ylva Waldemarsson, \& Kjell Österberg (eds.), Det långa 1900-talet: när Sverige förändrades (Finland: Boréa, 2014).

Ringarp, Johanna. Professionens problematik: lärarkårens kommunalisering och välfärdsstatens förvandling (Stockholm: Makadam, 2011).

Ringarp, Johanna. "From Bildung to Entrepreneurship: Trends in Education Policy in Sweden”, Policy Futures in Education 11.4 (2013): 456-464.

Roederer, Pierre-Louis. L'esprit de la Révolution de 1789 (Paris, 1831).

Rosa, Hartmut. "Social Acceleration: Ethical and Political Consequences of a Desynchronized High-speed Society”, in Hartmut Rosa \& William E. Scheuerman (eds.), High-Speed Society: Social Acceleration, Power and Modernity (Pennsylvania: Penn State University Press, 2009).

Rosa, Hartmut \& William E. Scheuerman (eds.). High-Speed Society: Social Acceleration, Power and Modernity (Pennsylvania: Penn State University Press, 2009).

Rosa, Hartmut. Resonsanz: Eine Soziologie der Weltbeziehung (Berlin: Suhrkamp, 2016).

Rosa, Hartmut. Social Acceleration: A New Theory of Modernity (New York: Columbia University Press, 2013).

Rosanvallon, Pierre. La société des égaux (Paris: Éditions du Seuil, 2011).

Rosanvallon, Pierre. Le moment Guizot (Paris: Gallimard, 1985).

Rosenquist, Joachim. Pluralism and Unity in Education: On Education for Democratic Citizenship and Personal Autonomy in a Pluralist Society (Örebro: Örebro Universitet, 2011).

Runeby, Nils. Den nya världen och den gamla (Stockholm: Svenska bokförlaget, 1969). 


\section{BIBLIOGRAPHY}

Rüsen, Jörn. Berättande och förnuft: Historieteoretiska texter (Göteborg: Daidalos, 2004).

Rüsen, Jörn. "Tradition: A Principle of Historical Sense-Generation and its Logic and Effect in Historical Culture", History and Theory 51.6 (2012): 45-59.

Sandgren, Petter. Internatskolorna: att fostra en elit (Stockholm: Atlantis, 2015).

Sandler, Richard. Mångfald eller enfald (Stockholm: Tiden, 1937).

Satz, Debra. "Equality, Adequacy and Education”, Ethics 117.4 (2007): 623-648.

Scheffler, Samuel. "What is Egalitarianism?”, Philosophy \& Public Affairs 31.1 (2003): 5-39.

Sejersted, Francis. Socialdemokratins tidsålder: Sverige och Norge under 1900-talet (Nora: Nya Doxa, 2005).

Semola, Hannu. "Construction of the Finnish Teacher in the National Steering Documents of the 1990s. Tasks and Qualifications", in Kirsti Klette, Ingrid Carlgren, J. Rasmussen, Hannu Simula, \& M. Sundqvist (eds.), Reform Policy and Teacher Professionalism in Different Nordic Countries (Oslo: University of Oslo, 2000).

Sen, Amartya. "Utilitarianism and Welfarism", The Journal of Philosophy 76.9 (1979): 463-489.

Sennett, Richard. The Fall of Public Man (New York: W.W. Norton \& Company, 1992).

Siedentop, Larry. "Two Liberal Traditions”, in Raf Geenens \& Helena Rosenblatt (eds.), French Liberalism from Montesquieu to the Present Day (Cambridge: Cambridge University Press, 2012).

Siedentop, Larry. Inventing the Individual: The Origins of Western Liberalism (Cambridge, MA: Belknap Press, 2014).

Sikora, Richard I. "Six Viewpoints for Assessing Egalitarian Distribution Schemes”, Ethics 99.3 (1989): 492-502.

Sipiora, Phillip. "Introduction: Ancient Concept of Kairos", in Phillip Sipiora and James S. Baumlin (eds.), Rhetoric and Kairos: Essays in History, Theory and Praxis, (Albany: State University of New York Press, 2002).

Skinner, Quentin. Liberty Before Liberalism (Cambridge: Cambridge University Press, 2012).

Skinner, Quentin. Visions of Politics, Volume 1 (Cambridge: Cambridge University Press, 2002).

Skoglund, Crister. Vita mössor under röda fanor: Vänsterstudenter, kulturradikalism och bildningsideal i Sverige 1880-1940 (Stockholm: Almqvist \& Wiksell, 1991).

Smeyers, Paul, Richard Smith, \& Paul Standish. The Therapy of Education: Philosophy, Happiness and Personal Growth (Basingstoke: Palgrave Macmillan, 2010).

Smith, John E. "Time, Times and the Right Time; Chronos and Kairos", The Monist, 53.1 (1969): 1-13. 


\section{The APORIA OF EqUALITY}

SOU 1935:35, Betänkande och förslag angående obligatorisk sjuårigfolkskola (Stockholm, 1935).

SOU 1944:20, Skolan i samhällets tjänst: Frågeställningar och problemläge (Stockholm, 1944).

SOU 1948:27, 1946-års skolkommissions betänkande med förslag till riktlinjer för det svenska skolväsendets utveckling (Stockholm, 1948).

SOU 1952:33, Den första lärarhögskolan (Stockholm, 1952).

SOU 1965:29, Lärarutbildningen (Stockholm, 1965).

SOU 1974:53, Skolans arbetsmiljö (Stockholm, 1974).

SOU 1975:9, Individen och skolan (Stockholm, 1975).

SOU 1978:86, Lärare i skola för utveckling (Stockholm, 1978).

SOU 1985:35, Skola for delaktighet (Stockholm, 1985).

SOU 1990:44, Demokrati och makt i Sverige: Maktutredningens huvudrapport (Stockholm, 1990).

SOU 1992:94, Skola för bildning (Stockholm, 1992).

SOU 1996:143, Krock eller möte - om den mångkulturella skolan (Stockholm, 1996).

SOU 1997:121, Skolfrågor - Om skola $i$ en ny tid (Stockholm 1997).

SOU 2006:40, Utbildningens dilemma - demokratiska ideal och andrafierande praxis

(Stockholm, 2006).

SOU 2008:27, Framtidsvägen - en reformerad gymnasieskola (Stockholm, 2008).

SOU 2014:5, Staten fär inte abdikera - om kommunialiseringen av den svenska skolan (Stockholm, 2014).

Spross, Linn. Ett välfärdsstatligt dilemma: Statens formuleringar av en arbetstidsfråga 1919-2002 (Uppsala: Acta Universitatis Upsaliensis, 2016).

Statius, Pierre. De l'éducation des modernes: Réflexions sur la crise de l'école à l'âge démocratique (Paris: l'Harmattan, 2009).

Stenlås, Niklas. "En kår i kläm - läraryrket mellan professionella ideal och statliga reformideologier”. Rapport till expertgruppen för studier i offentlig ekonomi (2009): 6.

Stenlås, Niklas. "Läraryrket mellan autonomi och statliga reformideologier". Arbetsmarknad \&' Arbetsliv, 17.4 (2011): 11-27.

Stensöta, Helena. Den empatiska staten (Göteborg: Göteborgs universitet, 2004).

“Strategi för entreprenörskap inom utbildningsområdet” (Regeringskansliet Näringsdepartementet \& Utbildningsdepartementet, 2009).

Straume, Ingrid. "A Common World? Arendt, Castoriadis and Political Creation", European Journal of Social Theory 15.3 (2012): 367-383.

Stråth, Bo. "Identity and Social Solidarity: An Ignored Connection. A Historical Perspective on the State of Europe and its Nations", Nations and Nationalism 23.2 (2017): 227-247.

Stråth, Bo. "The Faces of Modernity: Crisis, Kairos, Chronos - Koselleck Versus Hegel”, in Henning Trüper, Dipesh Chakrabarty, \& Sanjay Subrahmanyam 


\section{BIBLIOGRAPHY}

(eds.), Historical Teleologies in the Modern World(London/New York:

Bloomsbury, 2015).

Sundberg, Daniel. Skolreformernas dilemman: En läroplansteoretisk studie av kampen om tid $i$ den svenska obligatoriska skolan (Växjö: Växjö universitet, 2005).

Sundgren, Per. Arbetarrörelsen och kulturen: Kulturpolitiska strävanden från August Palm till Tage Erlander (Stockholm: Carlsson Förlag, 2007).

Sundgren, Per. Smakfostran - en attityd i folkbildning och kulturliv (unpublished paper, 2001).

Swedberg, Richard. "Before theory comes theorizing or how to make social science more interesting", The British Journal of Sociology 67.1 (2016): 5-22.

Swedberg, Richard. "Tillbaka till Tocqueville? Om Tocquevilles betydelse för förståelsen av de borgerliga eliternas uppgång och fall”, Statsvetenskaplig tidskrift 103 (2000): 221-234.

Säljö, Roger. Lärande i praktiken (Stockholm: Prisma, 2000).

Tegen, Einar. "Den demokratiska uppfostrans mål”, Skola och samhälle 3-4 (1945).

Thörn, Håkan. Modernitet, sociologi och sociala rörelser (Göteborg: Sociologiska institutionen Göteborgs universitet, 1997).

Tocqueville, Alexis de. De la démocratie en Amérique 1 (Paris: Flammarion, 1981a [1835]).

Tocqueville, Alexis de. De la démocratie en Amérique 2 (Paris: Flammarion, $1981 \mathrm{~b}$ [1840]).

Tocqueville, Alexis de. Democracy in America (New York: D. Appleton and Company, 1899).

Tocqueville, Alexis de. L'ancien régime et la revolution (Paris: Flammarion, 1988 [1856]).

Tönnies, Ferdinand. Community and Civil Society (Cambridge: Cambridge University Press, 2001 [1887]).

Urbinati, Nadia. "Competing for Liberty: The Republican Critique of Democracy", American Political Science Review 106.3 (2012): 607-621.

Villa, Dana. Public Freedom (Princeton: Princeton University Press, 2008).

Villey, Michel. Le Droit et les Droits de L'Homme (Paris: PUF, 2014).

Vinterek, Monika. "Individualisering i ett skolsammanhang", Forskning ifokus 31, Myndigheten för skolutveckling (Liber: Kalmar, 2006).

Virilio, Paul. Vitésse et politique (Paris: Édition Galilée, 1977).

Wahlgren, Ninni. Om det förändrade ansvaret för skolan (Örebro: Örebro universitet, 2002). 


\section{THE APORIA OF EQUALITY}

Wallin, Erik. "Svensk utbildningsteknologi - dess uppgång och nedgång åren 1960-1980", Studies in Educational Policy and Educational Philosophy, E-tidskrift (2006): 1 .

Walzer, Michael. Spheres of Justice (New York: Basic Books, 1983).

Wang, Sun-Joon. “Kampen om begreppet valfrihet i skolpolitiken”, Kommunal ekonomi och politik 6.2 (2002): 7-44.

Wedin, Tomas, \& Carl Wilén. "Equality from Athenian Democracy to the American Revolution: On the Limits of Modern Democracy in Arendt and Meiksins Wood”, Distinktion: Journal of Social Theory (forthcoming).

Wedin, Tomas. "Countering the Paradoxes of Equality: Three Politico-Temporal Approaches", unpublished article.

Wedin, Tomas. "Education and Emotions: From One Emotional Logic to Another”, Conference Proceedings: The Future of Education (Florence: Libreria Universitaria, 2018a).

Wedin, Tomas. "Educational Equality: A Politico-Temporal Approach”, Journal of Philosophy of Education (2018b).

Wedin, Tomas. "Ideological Continuity and Discursive Changes in the Swedish Educational System”, LIR-journal 3.13 (2013): 49-65.

Wedin, Tomas. "In Praise of the Present: The Pupil in Centre in Swedish Educational Politics”, History of Education (2017a): 768-787.

Wedin, Tomas. "The Democratic Paradox: On the Modified Teacher Role in PostWar Sweden”, Confero 5.1 (2017b): 193-241.

Wedin, Tomas. "The Rise of the Knowledge School and its Relation to the Resurrection of Bildung", Nordic Journal of Educational History 2.2 (2015): 49-67.

Wedin, Tomas. "Tocqueville, Educational Policies and Individualisation: On the Democratisation of Post-War Educational Policies in Sweden”, Lychnos (2018). 73-97.

White, Hayden. "Historical Pluralism”, Critical Inquiry 12.3 (1986): 480-493.

White, Hayden. The Content of the Form: Narrative Discourse and Historical Representation (Baltimore: Johns Hopkins University Press, 1990).

Widhe, Olle. "Estetisering och avestetisering: Nedslag i de svenska läroplanernas tal om läslust från 1906 till 2011”, Birgitta Ljung Egeland, Christina OlinScheller, Marie Tanner, \& Michael Tengberg (eds.), Tolfte nationella konferensen $i$ svenska med didaktiska inriktning (Karlstad: Karlstads Universitet, 2016).

Widmeier, Carole. Fin de la philosophie politique (Paris: CNRS éditions, 2012).

Wiklund, Martin. "Den historiska kunskapens praktiska ändamål”, Scandia 79.2 (2013): 113-124.

Wiklund, Martin. "Ett ansvarslöst ansvar? Om historikerns ansvar för historiska lärdomar”, in Patrizia Lorenzoni \& Ulla Manns (eds.), Historiens hemvist, vol. II: Etik, politik och historikerns ansvar (Göteborg/Stockholm: Makadam, 2016). 


\section{BIBLIOGRAPHY}

Wiklund, Martin. "Meaning in History Beyond Instrumental Rationality: The Concepts of Meaning and Rationality of Meaning in Jörn Rüsen's Theory of History", Ideas in History 2 (2008): 57-86.

Wiklund, Martin. Historia som domstol: Historisk värdering och retorisk argumentation kring “68” (Nora: Nya Doxa, 2012).

Wiklund, Martin. I det modernas landskap (Stockholm: Symposium, 2006).

Wiklund, Matilda. Kunskapens fanbärare (Örebro: Örebro universitet, 2006).

Williams, Andrew, \& Matthew Clayton (eds.). The Ideal of Equality (Basingstoke: Palgrave Macmillan, 2002).

Williams, Andrew, \& Matthew Clayton (eds.). Social Justice (Oxford: Blackwell, 2004).

Williams, Raymond. "Culture", in Keywords: A Vocabulary of Culture and Society (London: Fontana, 1988).

Young, Michael. The Rise of the Meritocracy 1870-2033: An Essay on Education and Equality (London: Penguin Books, 1961).

Ziehe, Thomas. Kulturanalyser: Ungdom, utbildning och modernitet (Stockholm/Stehag: Symposium Bokförlag, 1989).

Zijderveld, Anton. The Institutional Imperative (Amsterdam: Amsterdam University Press, 2000).

Östling, Johan. Nazismens sensmoral (Stockholm: Atlantis, 2008). 

Appendix I: In Praise of the Present: The Pupil in Centre in Swedish Educational Politics 



\title{
In praise of the present: the pupil at centre in Swedish educational politics in the post-war period
}

\author{
Tomas Wedin \\ Department of History of Ideas, University of Gothenburg, Gothenburg, Sweden
}

\begin{abstract}
According to an influential narrative in Swedish educational historiography, the Swedish educational system underwent a drastic change during the 1990s, moving towards a more individualistic and marketised system. Without denying the relevance of this perspective, this article argues that we can trace antecedents to the reforms undertaken in the 1990s far back in post-war education policies. It maintains that the endeavour to democratise the educational system during the post war years when radicalised, started to counteract these democratic tendencies. Applying what French historian François Hartog names 'regimes of historicity' as an analytical tool, it argues that a politically pertinent shift took place in the 1970 s. Since then, an increasingly stronger emphasis on the present at the expense of both past and future has contributed to an undermining of the centralised comprehensive school.
\end{abstract}

\section{ARTICLE HISTORY}

Received 9 November 2016 Accepted 6 August 2017

\section{KEYWORDS}

Presentism; pupil; equality; individualisation; democratisation

To take advantage of this desire for responsibility is furthermore a way to prepare pupils for their tasks in democratic society. It doesn't really make sense to speak about an intensification of democracy in our society, if we do not give youths the opportunity to apply democratic methods already in school. ${ }^{1}$

Swedish political development throughout the post-war period until the second half of the 1980 s is generally considered to manifest a collectivist model of society. ${ }^{2}$ In contrast, the reforms made since the late 1980s have often been interpreted as manifestations of increasingly individualistic tendencies. They have been considered part of a neo-liberalisation of Swedish politics, following the path of other western countries. ${ }^{3}$ In terms of redistribution

CONTACT Tomas Wedin Tomas.wedin@gu.se

${ }^{1}$ Educational Minister Olof Palme (Social Democratic Party), parliament statement on December 4, 1968 in a debate regarding a new curriculum for the comprehensive school, reprinted in: Gunnar Richardson, ed., Minnen och dokument. 9, Spjutspets mot framtiden (Uppsala: Föreningen för svensk undervisningshistoria, 1997), 44.

${ }^{2}$ Tomas Englund, Läroplanens och skolkunskapens politiska dimension (Göteborg: Daidalos, 2005); Mattias Börjesson, Från likvärdighet till marknad: en studie av offentligt och privat inflytande över skolans styrning i svensk utbildningspolitik 1969-1999 (Örebro: Örebro University, 2016).

${ }^{3}$ Kristina Boréus, Högervåg: nyliberalismen och kampen om språket 1969-1989 (Stockholm: Tiden, 1994); Peter Antman, ed., Systemskifte: fyra folkhemsdebatter (Stockholm Carlsson, 1993); Anders Ivarsson Westerberg, Ylva Waldemarsson and Kjell Österberg, Det långa 1990-talet: när Sverige förändrades (Umeå: Boréa, 2014); and David Harvey, A Brief History of Neoliberalism (Oxford: Oxford University Press, 2005). 
of material resources and economic policies, it is undeniable that important changes have taken place since the late 1980s. ${ }^{4}$

The school reforms launched during this period have also been considered manifestations of this ideological shift; having been one of the world's most centralised educational systems, Sweden has become one of the most liberal systems in the world in terms of marketisation and decentralisation. ${ }^{5}$ A clear indication of this is the introduction of a voucher system in the early $1990 \mathrm{~s}^{6}{ }^{6}$ These changes are commonly seen as examples of fundamental structural reforms. ${ }^{7}$

In contrast to this narrative, the purpose of this paper is to present a hitherto often overlooked aspect of continuity in post-war educational policies. By dint of assessing how the post-war ideal of centring the pupil in the educational process changed throughout the period, I argue that the introduction of a voucher system in the early 1990s could partly be considered an answer to a critical impulse going all the way back to the school commission of 1946, with a noteworthy shift of emphasis taking place from the 1970s. I maintain that an increased focus on what was at hand in the present - at the individual level of the pupil as well as at a societal level - gradually replaced the earlier dominant ideal of preparing pupils for the future.

Analysing how the individual pupil has been indirectly articulated in policy documents, I touch upon the much-discussed question of individualisation during the post-war period. ${ }^{8}$ In the concluding section, the changing position of the individual pupil is related to a continuous shift from one ideal of equality to another during the period, both intimately intertwined with an ever-greater emphasis on the present. The analytical category of centring the individual pupil and the theoretical category of equality thus serve primarily to clarify the main purpose of the study, ie to analyse what seems to be a shift from a future-oriented regime of historicity to a presentist regime. As expressed in the opening quote from the 1968 Educational Minister Olof Palme (Social Democratic Party), an essential driving force behind this move towards the present was the endeavour to democratise the educational system.

The problem is assessed via an examination of how the individual pupil was articulated in pertinent policy documents between 1935 and 1992. The individual pupil will be approached

4Jenny Andersson and Kjell Österberg, Nordstedts Sveriges historia 1965-2012 (Stockholm: Nordstedts, 2013), 15-16; Boréus, Högervåg.

5Lisbeth Lundahl, 'Decentralisation, Deregulation, Quasi-markets - and then What?' Journal of Education Policy 17, no. 6 (2002): 687-97; Michael Baggesen Klitgaard,'Do Welfare State Regimes Determine Public Sector Reforms? Choice Reforms in American, Swedish and German Schools', Scandinavian Political Studies 30, no. 4 (2007): 444-68; and Nihad Bunar, 'Choosing for Quality or Inequality: Current Perspectives on the Implementation of School Choice Policy in Sweden', Journal of Education Policy 25, no. 1 (2010): 1-18.

${ }^{6}$ For a discussion concerning this, see for example: Jenny Kallstenius, De mångkulturella innerstadsskolorna: om skolval, segregation och utbildningsstrategier i Stockholm (Stockholm: Acta Universitatis Stockholmiensis, 2010); Lisbeth Lundahl, Inger Erixon, Anne-Sofie Holm and Ulf Lundström, Gymnasiet som marknad (Umeå: Boréa, 2014); Marianne Dovemark, Ansvar - flexibilitet - valfrihet: en etnografisk studie om en skola i förändring (Göteborg: Acta Universitatis Gothoburgensis, 2004); and Nihad Bunar, När marknaden kom till förorten: valfrihet, konkurrens och symboliskt kapital i mångkulturella områdens skolor (Lund: Studentlitteratur, 2009).

${ }^{7}$ Tomas Englund, ed., Utbildningspolitiskt systemskifte? (Stockholm: HLS, 1996); Tomas Englund et al., Vadå likvärdighet (Göteborg: Daidalos, 2008); Tomas Englund, 'Education as a Citizenship Right', Journal of Curriculum Studies 26, no. 4 (1994): 383-99; Ylva Boman, Utbildningspolitik i det andra moderna: om skolans normativa villkor (Örebro: Örebro universitet, 2002); and Börjesson, Från likvärdighet till marknad.

${ }^{8}$ See for example: Elisabeth Beck-Gernsheim and Ulrich Beck, Individualization (London: Sage 2001); Ulrich Beck, Wolfgang Bonss and Christoph Lau, 'The Theory of Reflexive Modernization', Theory, Culture \& Society 20, no. 2 (2003): 1-33; and Zygmunt Bauman, Individualized Society (Cambridge: Polity Press, 2001). 
indirectly, via the following external points of reference: the teachers' assumed authority; cultural heritage; and the forming potentiality of the subjects studied.

The aim of this study does not claim any comprehensive empirical ambitions; as such, further empirical studies are necessary to make stronger claims of generalisability. ${ }^{9}$ There are, nevertheless, at least two good reasons for making such an attempt anyway: one historical and one political. A major historical advantage of producing a compressed sketch is that it allows us to identify tendencies over longer periods. Indeed, the very theme itself seems to necessitate a more extended perspective. A second, political-theoretical reason for assessing educational issues from a more extended time period is that it opens up a more dynamic historical understanding of the educational political changes around 1990. ${ }^{10}$

In the introductory section, I briefly present the relevant points of departure for my analysis. In the second section, I present the empirical analysis. In the third and concluding section, I summarise my findings and pinpoint the major historical-political implications of the study.

\section{Introduction}

As the Swedish educational researcher Monika Vinterek demonstrates in a report for the Swedish National Agency for Education, individualisation is an ideal that appeared in a number of guises throughout the twentieth century, from the early proponents arguing for more individually based teaching, inspired by the 'New Education Fellowship' in England, via the confidence trusted in self-instructive teaching aids (as part of the educational technology of B. F. Skinner, which was so influential in Sweden), to the focus on projects and theme-based learning in the 1980s and onwards. ${ }^{11}$ In Vinterek's overview, however, the focus is on the question of individualisation in teaching-specific situations, and not as a more general societal tendency.

To render the identified movements comprehensible, I will apply what the French historian François Hartog calls regimes of historicity. ${ }^{12}$ This is defined as the way in which 'an individual or collective installs itself and deploys in time. ${ }^{13}$ What he wishes to capture with this definition is how the space of experience is related to the horizon of expectation in different historical times. In line with earlier research, he argues that an important break took place in the western world during the second half of the eighteenth century. ${ }^{14}$

\footnotetext{
IIn addition to the educational historian Joakim Landahl cited below, there at least two other studies strengthening my argument here: Piero Simeone Colla, L'héritage impensable (unpublished thesis, EHESS); Tomas Wedin, 'The Aporias of Equality' (2017, unpublished paper).

${ }^{10}$ Both of which are on the lines of the approach articulated in: Jo Guldi and David Armitage, eds., The History Manifesto (Cambridge: Cambridge University Press, 2014), 1-13.

${ }^{11}$ Vinterek, Individualisering i ett skolsammanhang, Forskning i fokus nr. 31, Myndigheten för skolutveckling (Liber: Kalmar, 2006); Joanna Giota, Individualiserad undervisning i skolan: en forskningsöversikt, Vetenskapsrådets rapportserie 3 : 2013 (Stockholm:Vetenskapsrådet, 2013). As Vinterek points out in her report, this is a tendency that resembles the school political rhetoric around information technology (IT) in the 1990s, see page $92-3$. For a discussion of the role of educational technology in post-war educational reforms, see: Erik Wallin, 'Svensk utbildningsteknologi - dess uppgång och nedgång åren 1960-1980', Studies in Educational Policy and Educational Philosophy, E-Journal 2006: 1. For an analysis of the rhetoric concerning IT and its potential use in educational contexts, see: Thomas Karlsohn, Teknik - Retorik - Kritik: om IT-bubblan och datoriseringen av den svenska skolan (Stockholm: Carlsson, 2009).

${ }^{12}$ François Hartog, Évidence de l'histoire (Gallimard: France, 2005); François Hartog, Régimes d'historicité (Paris: Seuil, 2012). ${ }^{13}$ Hartog, Régimes d'historicité, 13-14.

${ }^{14}$ Most notably, the German historian Reinhardt Koselleck, see: Reinhardt Koselleck, Futures Past: On the Semantics of Historical Time (Cambridge, MA: MIT Press, 1985).
} 
A modern, predominantly future-oriented regime then successively replaced the earlier, chiefly backward-oriented regime (with its varying focus on historia magistra vitae, circular ideas of history, etc.).

One of Hartog's major contributions is his reflection on what he claims to be the dominant regime of historicity since the 1970 s is the presentist regime. This relatively recent order has replaced the future-oriented regime of the nineteenth and twentieth centuries. In tracking its origins, Hartog discusses a number of different currents and thinkers. Among others, he mentions Filippo Tommaso Marinetti, the author of the Futurist manifesto, and Roquetin's position in Jean-Paul Sartre's novel La Nausée. ${ }^{15}$ However, a firmer shift is discernible from the 1970s, as the already abating post-war boom was interrupted by the collapse of Bretton Woods and the oil crisis of 1973. These events prompted a rather gloomy outlook, with the consequence that the present expanded at the expense of the future.

This is comparable to what Swedish educational historian Joakim Landahl argues in a recent study, where he compares the introduction of Civics (Samhällskunskap) as a subject in the post-war school with Life-skills (Livskunskap) in the 1990s. One of his key arguments is that Civics could be considered a future-oriented subject, where the aim is to prepare the pupil for becoming a citizen, and as such an emblematically modern subject. In Lifeskills, on the other hand, the focus is rather directed towards the pupil as an individual in the present. In this sense, it could be considered symptomatic of our late modern society. ${ }^{16}$ Life-skills, Landahl continues, operate without any clear reference to society in a broader sense. It appears to be limited to the social-psychological nets into which the individual pupil is woven. ${ }^{17}$ The implicit narrowing of an assumed shared societal framework could therefore be coupled with the shrinking time horizon and in this sense seen as an indication of a presentist regime of historicity. ${ }^{18}$ The chronology following from Landahl's analysis is in line with earlier research, according to which a more individualist approach to politics is discernible around the first half of the 1990s.

However, when analysing the latter reforms in light of the tendencies that I point out below, the square-break narrative often used in the Swedish school debate seems more dubious. ${ }^{19}$ Applying the concept of presentism, I argue that the convictions of the 1970s and 1980s continued to echo also in the neoliberal wave of 1990. In a relevant sense, the undermining of early post-war Social Democratic school politics could thus be said to have started earlier. Tackling the material with Hartog's concept of regimes of historicity, I thus argue that we can reveal a dimension of the political changes in the 1990s that has been seldom highlighted. Not denying the relevance of the many analyses stressing how the school policies around 1990 constitute a digression, I argue that the perspective presented here provides us with a more historically dynamic understanding of the manifest changes.

\footnotetext{
${ }^{15}$ Hartog, Régimes d'historicité, 149-57.

${ }^{16} J$ oakim Landahl,'Skolämnen och moralisk fostran: En komparativ studie av samhällskunskap och livskunskap', Nordic Journal of Educational History 2, no. 2 (2015): 27-47.

${ }^{17}$ Thus intersecting with the idea of an ongoing therapeutisation in different spheres of society in the western world, see: Frank Furedi, Therapy Culture: Cultivating Vulnerability in an Uncertain Age (London: Routledge, 2004); Frank Furedi, Wasted: Why Education Isn't Educating (London: Continuum, 2009); and Paul Smeyers, Richard Smith and Paul Standish, The Therapy of Education: Philosophy, Happiness and Personal Growth (Basingstoke: Palgrave Macmillan, 2010).

${ }^{18} \mathrm{Hartog}$, Régimes d'historicité.

${ }^{19}$ Concerning Landahl's argumentation, this does not clearly and necessarily follow. The fact that Life-skills is indicative of a presentist regime does not imply that Landahl assumes that a shift took place in the 1990s. It only follows that the 1990s could be characterised as presentistic.
} 
The question is approached by way of examining school-related Official Reports of the Swedish Government (Statens offentliga utredningar, SOU) concerning school policies from 1935 to 1992 . For the sake of clarity and to avoid unnecessary neologisms, I shall use the common Swedish abbreviation, SOU, or simply the report when referring to the documents. All quotes from the reports and other policy documents are my own translations from Swedish to English. The SOU of the 1935 commission is included in the study in order to grasp the political shifts between the pre- and post-war approaches to the phenomenon. Material from seven SOUs is presented. ${ }^{20}$

The pupil at the centre is an ideal that influenced educational policies throughout the period. Approaching it via the indirect analytical definition given above, I argue that it has been modified while remaining within the confines of the overarching policy ideal. The aspects that I highlight do not therefore immediately coincide with the overarching instructions from the government to commissioners. My focus is on how the ideal has changed and how these shifts can be related to different regimes of historicity. It is, moreover, precisely the mutability of the ideal that makes the analytical construction so apposite, as it permits us to follow the ideal through the relevant shifts of nuances that it underwent during the period.

SOUs are valuable sources of information for our understanding of the political landscape in Sweden. They are prepared in order to provide government and parliament with an enlarged basis of information and recommendations before taking decisions. Their purpose is to map different aspects of the question at hand, analyse problems highlighted by the minister demanding it, and (sometimes) to recommend measures addressing the problems. ${ }^{21}$ Given that persons with different knowledge and skills work together and are expected to compromise and weigh their different opinions against each other, the reports are also assumed to limit the risk of retrospective critique. ${ }^{22}$ When trying to encapsulate societal tendencies, they are therefore of particular epistemic relevance. However, since they serve only to prepare changes, they must not be confused with the decisions finally taken. Nevertheless, SOUs are unique in offering important insights in the central ideas which lay behind the reforms implemented.

\section{Centring the pupil - the reports}

\subsection{The report of 1935: A report and proposition concerning the mandatory seven-year elementary school23}

The main directive of the commission, which was not given any name, was to query and present a suggestion for an eventual seventh year of mandatory school. In the 1930s, Sweden

\footnotetext{
${ }^{20}$ Throughout the period, I have found in total 93 reports that relate to teaching in normal primary and secondary education. Of these, I have read through the 12 reports that were particularly interesting for providing answers to the problem at hand, and from these I have chosen seven.

${ }^{21}$ Ulf Olsson, Folkhälsa som pedagogiskt projekt (Stockholm: Almqvist \& Wiksell International, 1997), 46.

${ }^{22}$ Jan Johanson, Det statliga kommittéväsendet. Kunskap-kontroll-konsensus (Stockholm: Statsvetenskapliga institutionen Stockholms universitet, 1992).

${ }^{23}$ Betänkande och förslag angående obligatorisk sjuårig folkskola SOU 1935: 58. As chairman for the mixed expert and parliamentary commission, permanent undersecretary of educational department, Nils Teofil Löwbeer was appointed. The rest of the commission consisted of: member of Second Chamber of Parliament and member of the Swedish National Debt Office Gustav Henning Andersson; member of Swedish National Agency for Education (Skolöverstyrelsen) Josef Emanuel Engvall; and public school inspector Nils Anton Persson. Research assistant Enar Cyprianus Sahlin was appointed chief secretary. The Swedish school administration changed its name to Skolverket from Skolöverstyrelsen in 1991. As the Swedish professor in educational sciences Ninni Wahlström shows in her dissertation, this change of name was indicative of the school political changes during this time, see: Ninni Wahlström, Om det förändrade ansvaret för skolan (Örebro: Örebro universitet, 2002), 217-18.
} 
was in the midst of profound societal changes. It was a time when, as Marquis Childs put it, the historical phenomenon of the 'middle way' took form after decades of harsh social conflicts. ${ }^{24}$ It was a time when the Alva and Gunnar Myrdal published Crisis in the Population Question (1934), advocating what they referred to as 'prophylactic social politics', aiming at generating a more efficient and equal social politics. ${ }^{25}$ When the Swedish Social Democratic Party won the election in 1932, a 44-year period of governmental power was initiated.

Under the headline 'Is a general extension of the Elementary School tuition with a seventh school-year desirable and possible', the commission emphasises the school political continuity of the last 90 years. ${ }^{26}$ They do this in quoting the 1841 parliamentary protocol, shortly after the decision had been taken to create a public school formally open to everyone:

Society must be entitled to demand from each of its members not only that he poses no threat, but that he also possesses an amount of knowledge sufficiently vast for making of him a useful citizen, capable of properly grasping his civic duties. ${ }^{27}$

The society for which the national public school reform was made was one where, as Swedish nineteenth-century poet Erik Gustav Geijer put it, the bourgeoisie shifted from 'being a part of to becoming 'the very expression of the whole' (emphasis added). ${ }^{28}$ The report stressed that the transformation of Swedish society initiated in the nineteenth century has since then - and in particular in the decade preceding the report - only intensified and made it 'very much harder for the youngster to find her/his feet in society than in former times.' ${ }^{29}$

Besides these structural changes, the committee adduces psychological arguments for extending the school time by a further year: observational skills are stronger; reasoning and contextual thinking have improved; and the ambition and receptivity of the child have strengthened. It is argued that the child is in need of ambitious and consistent 'guidance and discipline', where schools will have to take extended responsibility for the upbringing of children. ${ }^{30}$ In addition to alluding to the social changes that Swedish society had undergone, the report also draws attention to the importance of adjusting the educational system to swift economic changes. Economic development is now subject to the 'attentiveness, skills and capability of their citizens. ${ }^{31}$

The different arguments, psychological as well as structural, are then synthesised. With a new labour rights law (1931), where the minimum age for the right to hire minors was raised from 12 to 13 years, coupled with the increasing difficulty in distinguishing between industrial work (where the minimum age is 14) and non-industrial work, the committee concludes that the tendency seems to indicate a shift towards a general minimum age of 14 years. Consequently, it appears all the more motivated to extend school time by another

\footnotetext{
${ }^{24}$ Marquis W. Childs, Sweden: The Middle Way (London: Faber \& Faber, 1936). For studies on the development of the Swedish Social Democratic Party and the proclaimed ideal of people's home (Folkhem), see: Henrik Björck, Folkhemsbyggare (Stockholm: Atlantis, 2008); Tomas Jonsson, Att anpassa sig efter de möjliga: Utsugningsbegreppet och SAP:s ideologiska förändringar 1911-1944 (Gothenburg: Institutionen för idé- och lärdomshistoria, 2000).

${ }^{25}$ Alva Myrdal, Gunnar Myrdal, Kris i befolkningsfrågan (Nora: Nya Doxa, 1997), 205.

${ }^{26}$ SOU 1935:58, 44.

${ }^{27}$ Ibid., 46.

${ }^{28}$ Erik Gustav Geijer quoted in an earlier report, The Royal School Board's Reflection on the Commission Reports 1-5 SOU 1924:24, 15. This report does not form part of the primary material on which I draw, but is used strictly instrumentally for quoting Geijer.

${ }^{29}$ SOU 1935:58, 53.

${ }^{30} \mathrm{lbid}$., 54.

${ }^{31}$ Ibid., 53.
} 
year in order to fill the gap for those who would otherwise finish school at the age of 12-13. This would also be a way of fulfilling the primary aim of 'methodologically better transmitted knowledge as well as a strengthening of the upbringing role of school under a critical transition period for the pupils. ${ }^{32}$ At a time when the authority of the household and parents is in decline, it would be dangerous to leave some children outside the disciplining influence of schools, where they can learn about the privileges and duties that come with living in a society of law-bound liberty. ${ }^{33}$

Above and beyond bearing witness to this political conviction, their argumentation mirrors an educational ideal in which transmission was central. ${ }^{34}$ Transmission of both knowledge and norms was a crucial motivation. This was driven in part by the ever-increasing pace of the structural changes in the economy. But it was also deemed important to prevent some youths being left in a gap between the last school year and the age at which they could enter the labour market (14 years). Due to the decreased influence of the household on children and youths, it would fall on the state to extend its responsibility for bringing up new generations. The individual pupil needs to be prepared for the positions that he or she will fulfil in the future society.

\subsection{The 1946 report: a report with guidelines for Swedish educational system development ${ }^{35}$}

The primary task of the School Commission of 1946, was to construe a plan for the future organisation and guiding principles of the mandatory educational system, both from a shortand a long-term perspective. In 1940, a new chairman, wartime Minister of Education Gösta Bagge, was appointed to the commission at a time when much of its work was unfinished. Although the work of this previous commission, School in Service of Society, was voluminous, with around 4000 pages of text divided into 20 different reports, the reinstalled Social Democratic government, led by Per Albin Hansson, decided to launch another commission before the one led by Bagge, i.e. the commission of 1940, had completed its work. ${ }^{36}$ This move was motivated partly by the fact that other major (resource-intensive) reforms were

\footnotetext{
${ }^{32}$ bid., 57.

${ }^{33} \mathrm{Ibid} ., 100$.

${ }^{34}$ It goes without saying that it reflects other things as well. One of the more striking aspects of the document is the explicitness with which the intimate relationship between the labour market and the educational system is discussed. In the post-war period, the rhetoric undergoes a clear change of form, and then, with the reforms of the central-liberal government coalition from 2006 onwards, seems to return to the more explicit rhetoric. But this, as well as other approaches of the documents at hand, is a question that exceeds the scope of this article. See Englund; Läroplanens och skolkunskapens politiska dimension; Börjesson, Från likvärdighet till marknad.

${ }^{35}$ Betänkande med förslag till riktlinjer för det svenska skolväsendets utveckling SOU 1948:27. The original chairman for this mixed expert and parliament commission was Tage Erlander. After he had replaced Per Albin Hansson as Prime Minister (due to the latter's sudden death), Secretary of State Johan Joseph Emanuel Weijne was appointed as chairman. Under and together with him the commission was led by: editor Märta de Laval; professor in Greek at the University of Gothenburg Hans Ingemar Düring; member of Parliament and medicine licentiate Bertil von Friesen; association secretary Hilding Gunnar Edvin Albert Färm; Social Democratic politician, public debater and director of studies Alva Myrdal; member of the Second Chamber of Parliament Gustav Erik Nilsson; member of the First Chamber of Parliament and poor relief director Emil Erhard Näsström; director Knut Mauritz Gotthard Olsson; agronomist and member of First Chamber of Parliament Ivar Persson; member of First Chamber of Parliament Anna Maria Sjöström-Bengtsson; and member of Second Chamber of Parliament Adolf Valentin Wallentheim. Chief Secretary of the commission was doctor in literature and headmaster of state secondary grammar school of Hudiksvall, Stellan Arvidsson.

${ }^{36}$ Until the death of Per Albin Hansson in 1946, when Tage Erlander took over (with Östen Undén as intermediary Prime Minister for a few days before Erlander was elected).
} 
about to be launched. And since these reforms called for a further examination of the costs of a new school reform in any case, it was seen as worthwhile launching a new commission. ${ }^{37}$

Another reason was the rapidly increasing birth rates after the peace. This encouraged the government to take a more thorough approach to the educational question, including teacher education, school construction, etc., where the whole educational complex was taken into consideration. As the committee declares on the opening page of its report, from now on the school should not only reflect the democratic society for which the pupils are supposed to be prepared, but also aim at a 'democratisation of the Swedish school system.' Regarding the space of experience, this ambition must also be considered in light of the horrors of totalitarian regimes and the war. ${ }^{39}$

The commissioners argued that the democratic school must be 'an environment for the free growth of children'. ${ }^{40}$ The individuality and personal predispositions of pupils should be the very point of departure when structuring teaching and upbringing. However, this should not be considered as standing in opposition to the assumed desideratum that schools ought to venerate cultural heritage - that of 'our people' as well as that of humanity as a whole. ${ }^{41}$ On the contrary, only when learning is free can it inculcate this reverence: only through free upbringing can schools be a hotbed of a societal development based on the insights of each citizen. ${ }^{42}$ Therefore, I maintain, the formation of free democratic citizens, reverence for cultural heritage and free learning depended on each other; any one of them was not conceivable without the other two.

The intricate connection between the three is further strengthened by the repeated emphasis on school as a space aiming to refine pupils' taste. ${ }^{43}$ In order to obviate the connections between popular entertainment and low artistic qualities - be it films, music and/ or literature - the school must transmit an aesthetic education to the pupils, so that they can 'appropriate the treasures of cultural life and thereby live a richer life. ${ }^{\text {'4 }}$ In the classes of the mother tongue it is vital that children, at an early stage, 'learn to appreciate aesthetic values of poetry and, with time, learn to prefer good literature to bad. ${ }^{45}$ This must not, however, be interpreted as an ambition to give each student complete knowledge. As the commissioners argue, in accordance with the individual interest of each pupil, they should rather be given the opportunity to deepen their knowledge in specific areas. In order to

\footnotetext{
${ }^{37}$ SOU 1948:27, x. In Sweden as well as in most other Western European countries, theories by economists such as John Maynard Keynes sanctioned a more extensive role for the state in the economy, and with these changes came reforms aiming at improving the conditions of the working classes in the western world.

${ }^{38}$ SOU 1948:27, 1. For a comprehensive analysis of the school debates in the years immediately following the war, see: Gunnar Richardson, Drömmen om en ny skola: Idéer och realiteter i svensk skolpolitik 1945-1950 (Stockholm: Liber/Allmänna Förlag, 1983).

${ }^{39} \mathrm{See}$, eg, Johan Östling, Nazismens sensmoral: svenska erfarenheter i andra världskrigets efterdyning (Lund: Lunds universitet, 2008); Richardson, Drömmen om en ny skola.

${ }^{40}$ SOU 1948:27, 3, 22-3.

${ }^{41} \mathrm{lbid}$., 3 .

${ }^{42}$ lbid.

${ }^{43}$ Ibid., 7, 30-1, 266. The aim to promote cultural artefacts at the expense of entertainment was not limited to the educational system. It was also - and more controversially - directed towards a general audience. Examples of this include the commissioning of different investigations concerning: (i) Music Commission of 1947, SOU 1954:2; (ii) Art Commission of 1948, SOU 1956:13; and (iii) Film Commission of 1950, SOU 1951:1 in contemporary Swedish society.

${ }^{44}$ SOU 1948:27, 7.

${ }^{45}$ Ibid., 31.
} 
facilitate the appreciation of good art, they add that it would probably be easier if pupils were allowed to work more with modern literature, which they could relate to more easily than is currently the case. ${ }^{46}$ Whereas wider scope for the individual pupil is thus recommended, the horizon against which this liberty is assumed to gravitate is hovering in the background: there is a cultural heritage which is supposed to be handed over. The pupils should be educated to become citizens, and as such political equals, through the traditions of which they form a part. ${ }^{47}$

In addition, to emphasise the requirement that education must be approached in relation to the surrounding society, the report also mirrors the transcendental roots of the educational system that remain visible. ${ }^{48}$ At present, the commissioners complained, teaching in literature and history is often composed of 'dead content', content inadequate both:

... for the understanding of the cultural development in a wider sense, and to better understand the problems of our own time ... the school has on top of this neglected a vast array of skills, which are of an immediate relevance for practical life as a citizen. ${ }^{49}$

The commissioners go on to claim that the introduction of Civics (Samhällskunskap) as an entirely new subject in school should be understood in light of this. In an emblematic fashion, the account then takes an argumentative turn by embedding the just quoted paragraph into a larger framework:

It would, nevertheless, be fatal if the school considered the transmission of knowledge from an exclusively practical point of view. The transmission of knowledge ought ultimately to aim at the development of the personality, to a cultural conscience, to provide insight into the place of humanity in the cosmos, to encourage humility before the mystery of existence and to strive to locate one's own life in the bigger context. Coherent and deepened knowledge has its major value independent of the possibility to practically make use of them. The search for the truth and the orientation of life must be built on this, without which the field is left open for superstition and cultural decay. ${ }^{50}$

As indicated above, the framework within which the individual pupil is outlined here clearly stretches far beyond whichever ideas and interest he or she as an individual happens to harbour; the religiously loaded allusion, as well as the political community against which the individual is assumed to take form, is indisputable.

In relating microcosm with macrocosm, the 1946 school commission firmly situated the individual pupil within a framework stretching over time and space. The report's promotion of the ideas of democracy and equality aimed at forming pupils to become citizens. This is in line with what Hartog refers to as a future-oriented regime of historicity. Partly, the commissioners expected this to be realised via a confrontation with the past, for example in the form of cultural heritage. However, as these equality-driven and democratic ideals were radicalised, the time horizon was successively shifted.

\footnotetext{
${ }^{46}$ lbid., 31.

${ }^{47}$ Ibid., 6-7, 18.

${ }^{48}$ This dimension of the 1946 commission is further emphasised by the fact that, at that time, the commission report was still commissioned by the Ecclesial Department (Ecklesiastikdepartementet), which was not transformed into the Department of Education until 1968.

${ }^{49}$ lbid., 30.

${ }^{50}$ lbid.
} 


\subsection{The 1960 report: the teacher education program 51}

The report of the commission, given the name Expert Advisors on the Teacher Education Programme in the 1960s, was delivered in 1965. It was summoned to produce a report concerning the organisation of teachers around subjects and classes. As the commissioners behind the report stated, it was clearly the case that teacher training would have to be adjusted in light of the immense reforms made in the 1950s and 1960s. ${ }^{52}$ But how thorough should the reforms of the teacher training be? Would they have to be of a magnitude that 'enforces a complete revision of the very ambition' of teacher training? ${ }^{53}$

Drawing on the future orientation of the new curriculum for primary and lower secondary school, the commissioners underline how teaching should aim at creating an active citizen in the future society, which to a substantially larger degree than is currently the case will require active cooperation between people. ${ }^{54}$ Echoing the words of the 1946 commission, they add that the requirements of the individual and society must not be considered as aims pointing in different directions. They must rather be thought of as two dimensions converging in the credo of the child at the centre. In discussing the necessity of maintaining close links with the guardians of the pupils, the claim is made that the problem of discipline is 'not a problem of correction but ultimately a question of the form of the work in school. ${ }^{55}$ It comes down to awakening engagement and a willingness to cooperate through meaningful and active teaching.

It would nevertheless, the commissioners argue, be hasty to assume that the desired harmony between the force and responsibility of the individual pupil on the one hand, and communal spirit and responsibility on the other, would be brought about without any friction. This is an education that 'rests on the belief in the inherent forces of the pupil, [and] is always coupled with risk, that risk which liberty implies. ${ }^{56}$ To find elaborate forms where these aims coincide is one of the most pertinent challenges for the reformed school system. A reason for being optimistic about this issue, the commissioners add, is that it becoming increasingly important to learn how to learn rather than merely learning actual content; in any case, the latter might become 'peripheral and dated' tomorrow. ${ }^{57} \mathrm{~A}$ further, more pragmatic argument for relocating more responsibility to the individual pupil was that this would offer a solution to the increased heterogeneity of the classes. ${ }^{58}$ As a result,

\footnotetext{
${ }^{51}$ Lärarutbildningen: 1960-års lärarutbildningssakkunniga SOU 1965:29 The chairman of this expert committee was the previous Social Democratic general director Olle Karleby, at the time CEO of the Scandinavian Bank (which later merged with Stockholms Enskilda Bank and became SEB). Alongside him, we find the headmaster for the public school teachers'seminar Stellan Arvidsson, the headmaster for the teacher training college Eskil Källquist, the headmaster for the teacher training college in Gothenburg Börje Svensson and Arne Sönnerlind, senior supervisor at the Department for Education. When the commission in 1962 received some additional directives from government, five further expert advisers were called in: professor in quaternary geology Gunnar Hoppe; professor of education Torsten Husén; member of the Swedish National Agency for Education (Skolöverstyrelsen) Bertil Junnel; administrative director for the Swedish Teachers' Association Ingrid Linde; and the headmaster for the teacher training college in Uppsala Ruth Sävhagen. In the same year, another member of the Swedish National Agency for Education (Skolöverstyrelsen), Sixten Marklund, was appointed as expert and primary secretary.

${ }^{52}$ In particular, of course, the replacement of the parallel educational system with one single mandatory educational system (enhetsskolan), but at the same time public-secured pension insurances and the healthcare system also underwent profound changes.

${ }^{53}$ SOU 1965:29, 71.

${ }^{54}$ lbid., 77. The Comprehensive School [Enhetsskolan] with its corresponding curriculum was established in 1962.

${ }^{55} \mathrm{Ibid} ., 78$.

${ }^{56} \mathrm{lbid} ., 78$

${ }^{57}$ lbid., 83 .

${ }^{58}$ Indeed, as the school historian Gunnar Richardson has put it, the individualisation of teaching was a sine qua non for establishing the comprehensive school, see: Richardson, Drömmen om en ny skola, 154.
} 
it was considered necessary that the teacher transfer more and more responsibility to the pupils (either to the individual or to pupils collectively).

The reasons called forth for individualisation, I maintain, could be based on three relatively independent arguments. First, the idea that a democratic society must be based on democratic practices already at an early age; second, that individualisation is encouraged in order to release the innate forces of the pupil, which will remain inconclusively developed under the teacher-led classes; and third, the pragmatic argument that individualisation is necessary due to the heterogeneity of the classes in the common school.

In accordance with earlier cited reports, the commission also stressed the importance of providing all pupils with an aesthetic education sufficiently substantive to form grounds for further development as adults. This cultivation of judgement was not considered optional: all students must be part of it. It is a capacity to be cultivated in a number of different fields, although the mother tongue, drawing and music are particularly pertinent subjects. ${ }^{59}$ In some respects, this report could be seen as a continuation of the 1946 commission; the individual pupil is supposed to be prepared for the future via the past (through cultural heritage). In mentioning the increasingly transient character of knowledge and relating it to the meaning of teaching, the report also hints at the later, more progressive, forms of thinking that took shape during the 1970s. The report should, by implication, be considered future-oriented but with some formulations indicating early signs of a different, more presentist, regime of historicity.

\subsection{The 1975 report: the individual and the schoo/60}

This report, delivered by the Commission of the School, State and Municipalities, was written in the wake of the substantial critique of societal institutions, not least the educational system, of 1968. The commissioners' task was to analyse the division of responsibility between the state and the municipality. The critique directed against society at large targeted the educational system in particular. In virtue of being a centre of unequal relations, where the older were still supposed to transmit knowledge to the younger, it became a central object of critique. As indicated by the opening lines of Olof Palme, if an intensification of democracy in our society' is what we want, the youth ought to be given 'the opportunity to apply democratic methods already in school.'.1 ${ }^{1}$ Moreover, the school was criticised for still serving as a winnowing out system for the labour market. It was blamed for still playing a crucial role in the reproduction of a class society. ${ }^{62}$ In what concerned the school

\footnotetext{
${ }^{59} 1965: 29,84,88$.

60/ndividen och skolan SOU 1975:9. Director-general of the Swedish National Agency for Education (Skolöverstyrelsen) Jonas Orring was appointed as chairman for this mixed expert- and parliamentary-led commission. Together with him the following people formed the commission: member of parliament Lennart Andersson; general manager Sten-Sture Landström; secretary of state Ulf Larsson; member of parliament Jan-Erik Wikström, and head of a subdivision in the Swedish National Board of Education (Skolöverstyrelsen), Lennart Teveborg.

${ }^{61}$ Olof Palme, parliamentary statement from December 4, 1968 in a debate regarding a new curriculum for the comprehensive school, reprinted in: Richardson, Minnen och dokument. 9, 44.

${ }^{62}$ Boman, Utbildningspolitik i det andra moderna; Englund, Läroplanens och skolkunskapens politiska dimension, 268-72; Gunnar Richardson, Svensk utbildningshistoria - skola och samhälle förr och nu (Lund: Studentlitteratur, 2010), 14, 13840; Wahlström, Om det förändrade ansvaret för skolan, 53; Börjesson, Från likvärdighet till marknad; Johanna Ringarp, Professionens problematik: lärarkårens kommunalisering och välfärdsstatens förvandling (Stockholm: Makadam, 2011), 39-40, 46.
} 
organisation, the following quote is indicative of the political climate and the preceding decades of educational reforms:

One could now assume that the thorough outer reforms of the pre-university educational system are accomplished for the foreseeable future. For the school system, the task is now to search for even better ways to have all children and adolescents experience schoolwork as stimulating and teaching as meaningful. ${ }^{63}$

The above-presented depiction is not a recommendation by the commission, but an excerpt from the commission's directive. Furthermore, the ambition to render the work in school more stimulating and meaningful was not restricted to the pupils; it was also a matter of making it more stimulating for those employed in the school system. One way to achieve this was to increase the engagement of those employed in the 'concrete shaping of the school. ${ }^{4}$ The current rule-guided state control of schools was pointed out as one of the major obstacles to such a reorganisation. This order, it was argued, prohibited all those immediately engaged in schools from more directly engaging in the everyday structuring of the educational system. Apart from pupils and teachers, the commissioners also included parents, school boards, and other members of society.

There were two central preconditions for realising the aims called for in the commission directives: (i) the particular local unity, the school, is allowed an enlarged responsibility for adapting to local conditions; and, intimately linked to the first, (ii) municipalities are provided with an enlarged responsibility on the operational level for schools. A major amalgamation of municipalities had recently been undertaken, bringing down the number from around 2500 in the 1930s to around 280 at the end of the 1970s. As pedagogical researcher Ninni Wahlström points out, this was a central precondition for moving the issue of decentralisation up the agenda. ${ }^{65}$ Within a more locally based structure, it would be much easier to offer staff, pupils and parents more opportunities to influence organisational aspects of schools as well as the immediate running of them.

At the centre of the curricula for both primary/secondary education and high school education (1969 and 1970 respectively) stood the needs of individuals: they should form the basis from which content, forms and the organisation of work in schools should be structured. The school will strive to help:

... each pupil to get to know her/himself, to individually form an opinion of the demands made by society and school, and to address personal problems and develop her/his personality. This implies, among other things, that the active participation of the pupil in the shaping of work in school is decisive. ${ }^{66}$

Whereas the educational reforms during the preceding decades aimed at reorganising the outline and aims of pre-academic education, the time was now ripe, as indicated by the quote, for a thorough democratisation of the inner work of schools. As the first steps towards a more democratic educational system had been taken, school politicians faced the challenge of taking the next step in this reform process; to successively delegate more responsibility to those working in the schools and to the pupils themselves was now, it could be argued, the next logical step to take.

${ }^{63}$ SOU 1975:9, 11, 106.

${ }^{64}$ Ibid., 11.

${ }^{65}$ Wahlström, Om det förändrade ansvaret för skolan, 127.

${ }^{66}$ SOU 1975:9, 31. 
In repeating the post-war mantra of posing the individual pupil at the centre, and in their ambition to decentralise and renew the reformation by way of reorganising the inner organisation, the reformers, I contend, continued the democratic and equality-promoting tradition that was launched in 1946. This second phase of the democratisation of the educational system also fits neatly with other tendencies in society. One of the more important of these was the challenging of the Swedish model with the Social Democratic government legislating on the right to exercise influence in privately -owned enterprises. Another was the critique of the state, which was said to take decisions over people's heads. ${ }^{67}$ These changes harmonise with the dislocations outlined above, indicating a tendency to further emphasise the immediate realisation of democratic ideals. The preparatory dimension was, as a consequence, downplayed in favour of practices promoting the here and now.

\subsection{The 1978 report: teacher for a school in development ${ }^{68}$}

In line with the point of view sketched out in previous reports, that the outer reforms of the school system were now considered completed, the purpose of this report, delivered by Teachers Training Commission of 1974, was to query the aim, structure and content of the training for all pre-university teachers. Besides echoing earlier political tendencies, a number of formulations appear that indicate a shift within the continuity. A further aspect of the background was the increased critique of bureaucracy in Swedish society in the 1970s; a critique that the Social Democrats now considered a reason for their loss in the 1976 election. $^{69}$

In contrast to earlier reports, an interesting displacement of emphasis concerning the time-dimension in school takes place here. Whereas the school in former times aimed at preparing the pupils for working life, as citizens etc., the school that now took shape, the more democratic school, was expected to provide pupils with 'self-realisation, being-together-experiences and a common work in solidarity in the present' (emphasis added). ${ }^{70}$ The school, the commissioners argue, from now on must not focus solely on preparatory aspects of teaching, but also on the 'here-and-now-aspect.'.1 This desideratum is further emphasised by the expressed desire to alter teaching practices, in order to give pupils opportunities to influence and modify the society in which they live. ${ }^{72}$

Other themes, which appear in earlier reports, are further emphasised: democratic education could not be brought about under unequal terms, but must be addressed through a

\footnotetext{
${ }^{67}$ Börjesson, Från likvärdighet till marknad, 30.

${ }^{68}$ Betänkande av 1974-års lärarutbildning: Lärare för skola i utveckling SOU 1978:86. Maj Bossön-Nordbö, head of division at the Swedish Board of Education (Skolöverstyrelsen), was appointed chairman for this mixed expert and parliamentary commission. The following persons worked at her side: member of parliament Birgitta Dahl; member of parliament Lars Gustavsson; lector and local government commissioner Bertil Hansson; member of parliament Ove Nordstrandh; secretary Sten Persson; member of parliament Christina Rogestam; head of education at Swedish Confederation of Professional Employees (TCO) Lennart Larsson; the ombudsman Henry Persson, and the report secretary Sten Marcusson.

${ }^{69}$ Niklas Stenlås, 'En kår i kläm - Läraryrket mellan professionella ideal och statliga reformideologier', Expertgruppen för studier i offenlig ekonomi 2009:6, Department of Finance, 11.

${ }^{70}$ SOU 1978:86, 78 .

${ }^{71} \mathrm{lbid}$.

${ }^{72}$ Ibid., 79.
} 
democratic interplay between pupil and teacher, more like an act of cooperation between teacher and pupil. It is, furthermore, stressed that the pupil ought to have, as much as possible, 'the freedom for her/himself to create her/his educational programme. ${ }^{73}$ In harmony with these ideas was also the striving for a situation in which the pupil could become a mutual part in the evaluation of her or his development, rather than being subjected to a one-way evaluation by teachers.

Essentially, I do not read these ideas as a break with those highlighted in earlier reports. Instead, I think that they can best be thought of as relevant but not fundamental dislocations within a wider dynamic discernible in the examined documents. As seen above, comparable tendencies are identifiable all the way back to the major shift manifested in the post-war commission of 1946: the ambition to have schools approaching the rest of society; the progressivist-inspired ideas of child-centred teaching; and the solidly established critique of authorities in school.

Nonetheless, it is clear that the tone in the reports from the 1970s has undergone some notable shifts in nuances. Apart from the shift of time-perspective, with a new stronger emphasis on the present, in the later reports we do not find any of the counterweights pointing backwards towards the past: the acquisition of cultural heritage; the development of a sensibility for the 'mystery of existence. ${ }^{74}$ Here pupil-centred teaching seems to be not only a democratic and efficient method for bringing up the child, but also an opportunity for the child to realise both her-/himself and the democratic ideal in the present, satisfying the 'here-and-now' aspect. ${ }^{75}$ This dimension, the time compression where both past and future gravitate towards the present, reveals itself in the diminishing references to cultural heritage as a background against which the pupil is assumed to take form. But it is also manifested in the increased emphasis on delegating responsibility and influence to pupils in the present, rather than preparing them for life as citizens.

\subsection{The 1985 report: school for participation ${ }^{76}$}

Forming part of the overarching commission aiming at developing local democracy, this working group of the Democracy Committee of 1983 was summoned to analyse and furnish suggestions for increasing the cooperation, participation and responsibility in schools of both pupils and their parents. In the opening section, the commission begins by quoting Hugo, one of the two protagonists in the Swedish children's book Hugo and Josephine by Maria Gripe. ${ }^{77}$ Hugo is reflecting on why teachers are assumed to speak and impose their order on school activities. Hugo, the commissioners write, is:

... curious, active and uses all his senses to conquer knowledge and prefers to pose his own questions than answer those of the teacher. He cares for the well-being of other humans, defends weaker friends and perspicaciously sees through the feint of the adults. Hugo's traits exist

\footnotetext{
${ }^{73} \mid$ bid., 78.

${ }^{74}$ See note 50

${ }^{75}$ SOU 1978:86, 78.

${ }^{76}$ Skola för delaktighet 1985:30. As chairman for this mixed expert and parliamentary commission, county council commissioner Gunnel Färm was appointed. Alongside her we find: the local government commissioner Sven Lindgren; member of parliament Larz Johansson; local government commissioner Marita Bengtsson; expert adviser Johnny Nilsson; and public investigator Mats Ahnlund.

${ }^{77}$ Maria Gripe, Hugo och Josefin (Stockholm: Albert Bonniers Förlag, 1962).
} 
within all people if only we are given the opportunity to develop them. They are particularly pertinent when we are children. As we grow into school and society it is as if we become less and less curious, independent and active. Many develop a spirit of passive receptivity. Their own initiatives are reduced. ${ }^{78}$

The commissioners show that the educational system that started to take shape during the post-war period had taken important steps away from the long-established tradition of promoting submissiveness and passivity in a world divided between preachers and listeners, parents and children. Even though the new tradition, starting with the commission of 1946, successively has been replacing the old, we must not take anything for granted: 'it is an old presupposition that each new generation must be won for the democracy.' ${ }^{\text {' }}$

Of the measures that had been taken during recent decades, the commissioners argue, those that favoured a more decentralised school system and the new ideological ambition' of the school curriculum of 1980 (applicable to primary and lower secondary school) were particularly prominent. ${ }^{80}$ As regards decentralisation, praise is given to the increased influence of both pupils and their parents. These proclaimed achievements should in turn be seen in light of the broader ambition to decentralise important decisions in society on a more general level..$^{81}$ The report as a whole thus further emphasises the shift noted previously, wherein the individual pupil is increasingly ascribed a participatory role within the democratic community in the present.

\section{7. The 1992 report: a school for bildung ${ }^{82}$}

The chairman for this expert-led commission was director-general of the Swedish Board of Education, Ulf P. Lundgren. Under him we find: university teacher Kerstin Hägg; college lecturer Bodil Jönsson; secretary of the ministry Barbara Martin Korpi; head of division at the Swedish Board of Education Kerstin Mattson; head for educational issues at Volvo Rolf Nordanskog; ex-prefect at the Institute of Education in Stockholm Stig Persson; counsellor of the ministry Boo Sjögren; and the director-general at the state institute of disabled-related issues in Public Schools Lennart Teveborg. Director of studies Christer Axén served as main secretary. With the change of government in September 1991, the commission was extensively reorganised. Apart from the chairman and Boo Sjögren, all other members were dismissed and replaced by counsellor of the ministry Kerstin Thoursie and professor Tor Ragnar Gerholm, while director of studies Berit Hörnqvist was appointed main secretary. It was in the working group related to the latter that Ingrid Carlgren was appointed.

As the report was written, western society was in the midst of substantive change. These included the fall of the Soviet Union, an increasing number of refugees, and the ever-intensifying use of new and more powerful means of communication. In the specific case of Sweden, the work of the Curriculum Committee also coincided with a major economic crisis, stretching from 1990 onwards. The directives given to the commission were to analyse and

\footnotetext{
78SOU 1985:30, 9.

${ }^{79}$ lbid., 9.

80 lbid., 10.

${ }^{81}$ Wahlström, Om det förändrade ansvaret för skolan, 149.

${ }^{82}$ Skola för bildning SOU 1992:94
} 
present the aims and guidelines for the childcare system and public school system, with an explicit request to discuss the concepts of Bildung and knowledge. ${ }^{83}$

The commission was first appointed by the Social Democratic government that ruled until 1991 under Göran Persson as School Minister, and then slightly modified with the election of a liberal/right-wing government in 1991. Beatrice Ask from the Moderate Party then took charge of school-related issues. The structural changes outlined above served as the point of departure for the commissioners.

Besides these, the commissioners, for the first time since the 1946 commission, distanced themselves slightly from the post-war school development particularly in relation to the individual pupil. Especially targeted were the ideas in Sweden often referred to as educational technology, which influenced the educational policies of the first decades after the Second World War. ${ }^{84}$ More specifically, the strong tendency to think of teaching in terms of different developmental phases was challenged. With one of the leading researchers in the field of learning studies, Ingrid Carlgren, on the committee the mark of this shift in paradigm is notable. The conceptual couple 'development-learning' (utveckling-inlärning), the commissioners argue, is increasingly losing its relevance for our understanding of what learning is about. ${ }^{85}$ In its place, the commissioners proposed the socio-cultural perspective, where knowledge is 'neither something exterior, outside humans, nor anything inside the individual, but rather something that "lay in-between" the individual and the surroundings' ${ }^{86}$

For the individual pupil, this implied that knowledge was now thought of as something she/he develops by way of 'interacting with an environment?. ${ }^{87}$ Communication thus becomes a fundamental aspect of learning. I claim that this tenet is in turn intricately related to the constructivist conception of knowledge on which the report rests. ${ }^{88}$ Knowledge, it is argued, 'is not true or untrue, but something that can be argued for and tried; knowledge is disputable. ${ }^{89}$ Although in its emphasis and articulations a new phenomenon, the similarities between the emphasis in SOU 1965:29 on learning how to learn rather than focusing on the content, is not negligible, they coincide in their scepticism vis-à-vis a content-oriented conception of knowledge. In stressing this understanding of learning, the commissioners also implicitly vindicate an idea of education where learning happens in the interplay between teacher and pupil in the here and now. This should be contrasted with the traditional idea according to which the pupil internalises what others have thought before and what the

\footnotetext{
${ }^{83}$ I have deliberately chosen to exclude the scattered references to the 'cultural heritage' that appear in the document. Like the concept of Bildung, occurring in the title, these strike a discordant note in the report. Since the concept of knowledge that I focus on is more in line with other earlier as well as later school-related reports, I have chosen to ignore the presence of Bildung and the cultural heritage. On the development of similar themes after 1992, see: Wedin, 'The Aporias of Equality'. How the idiosyncratic surge of the cultural heritage could be explained is a question that merits an investigation in itself. Intuitively, it would seem reasonable to consider both the references to the cultural heritage as well as Bildung against the backdrop of an experience of historical rupture due to the fall of the Berlin Wall and the increased numbers of children with roots from outside Europe, etc., but it could also be considered a concession to the critique of the Knowledge Movement (see note 92 below). The commission was instructed from its directives to take due regard of both Bildung and cultural heritage. For a further analysis of the reactivation of the concept in the late 1970s, see: Tomas Wedin, 'The Rise of the Knowledge School and its Relation to the Resurrection of Bildung', Nordic Journal of Educational History 2, no. 2 (2015): 49-67.

${ }^{84} \mathrm{~F}$ or a discussion of this, see: Wallin, 'Svensk utbildningsteknologi'.

${ }^{85} \mathrm{SOU} 1992: 94,60$.

${ }^{86}$ SOU 1992:94, 73. Ingrid Carlgren was active in the development and then diffusion of the then novel 'socio-cultural' perspective on learning together with theoreticians such as Roger Säljö.

${ }^{87}$ SOU 1992:94, 74.

${ }^{88}$ For a closer analysis of this perspective on learning and how it affected educational policies, see: Jonas Linderoth, Lärarens återkomst (Stockholm: Natur \& Kultur, 2016).

${ }^{89}$ bid., 76.
} 
teacher tries to transmit. From a broader, societal perspective, the commissioners emphasise how the relations between adults and young people are increasingly characterised by camaraderie and equality. ${ }^{90}$

Another paragraph, echoing the demands of the Knowledge Movement (Kunskapsrörelsen) during the 1980s, concerns the question of responsibility. ${ }^{91}$ In accordance with the reforms recently launched, the importance of obligations on the side of the pupil is further emphasised:

An influence must always be attached to a responsibility. To the pupils this has often been reduced to taking care of their schoolwork, keeping times and following the rules stipulated by the school. If the task of the school to promote the development of the pupils to be responsible humans and members of society ... is to have real meaning, it is necessary that the pupils be given a new role. ${ }^{92}$

If the idea of providing the individual pupil with more influence is to have a meaning, it is necessary that the individual teacher 'assume that the pupils ... want and can take responsibility for their studies and their school situation..$^{93}$ This is the only way in which they can develop a democratic attitude. As in the report of 1985, responsibility here becomes interlaced with the essentially equality-endorsing ideas of individuals as born creative and competent. As highlighted earlier, this ideal of equality appears more firmly directed towards the immediate interaction between pupil and teacher. This approach should be contrasted with the future-oriented ideal of equality, according to which the school should prepare the individual pupil for becoming an equal among other citizens.

\section{Continuity and change}

In 1948, cultural decay was still a threat to the commissioners, and child-centred learning appeared primarily as a means. In the report of 1985, with its strongly emphasised generation-based idea of equality, the tone had changed. This dislocation can be reconstructed via two related ideas. First, we are facing a manifestation of the progressivist conviction that pupils learn by doing things, ie that practicing democracy here and now is the best way to prepare pupils to become democratic subjects. ${ }^{94}$ Second, there is the equality-promoting idea that children have a right to exercise more extensive influence over their education qua members of the democratic community. When radicalised, these two convictions, the pedagogical (the former) as well as the ideological (the latter), can be understood as expressions of what Hartog describes as a presentist regime of historicity. ${ }^{95}$ The path that led to the reforms around 1990 was thus paved by ideals that can be considered a radicalised heritage

\footnotetext{
${ }^{90}$ SOU 1992:92, 86.

${ }^{91}$ The knowledge movement was formed in 1979 as a response to what the founders viewed as an unfortunate development of the school since comprehensive school reform. The decree to relate to the concept of Bildung should also be understood in light of the educational debate that the Knowledge Movement provoked in the 1980s. For a discussion of the development of this movement, see: Colla, L'héritage impossible; Wedin, 'The Rise of the Knowledge School and its Relation to the Resurrection of Bildung'.

92SOU 1992:92, 105.

${ }^{93}$ SOU 1992:94, 106.

${ }^{94}$ By progressivism here I refer to the educational philosophical current, chiefly associated with John Dewey, that had a major impact on educational politics in a number of western countries throughout the twentieth century, particularly after the Second World War. This current must not be confused with progressivism as, eg, a form of more general, modern, ideological conviction.

${ }^{95}$ Hartog, Régimes d'historicité, 149-57.
} 
of school policies between the 1940s and 1960s. The school political alterations could therefore be understood as a dialectical movement where the post-war centralisation process in parallel should be considered a harbinger of the debates to come; how these movements took shape throughout the period becomes, as outlined above, discernible when following the analytical construction of the pupil at the centre.

In the first phase, the school was deemed the primary arena for preparing pupils for a community that both preceded and outlived them. The way into the future for pupils went via the past in the form of, for example, cultural heritage; the task of the comprehensive school (Enhetsskolan) was to give as many pupils as possible an opportunity to take part in this. This is a manifestation of a modern regime of historicity, where the future dictates whether and why certain restrictions are necessary; the pupil needs to be subjected to this in order to become a citizen. Until the 1970s, this dominated policy documents.

In the second phase, the pupils were successively transformed from potential future citizens to incarnations of a more direct route to the new, more equal and democratic, society. This was due in part to the radicalisation of progressivism and an increased intergenerational idea of equality. The very same ideals therefore now became forces to loosen up what they had inspired to construct 20-30 years earlier. In facilitating the shift towards the particular in the form of the pupil and her/his parents, and/or the local school, the radicalisation started to undermine what had hitherto been built up. This was done with the superior aim of further democratising the educational system and making it more equal. When radicalised, the same ideals thus turned against the very same (future-oriented) ideal from which they had originally grown.

Hence, the ideals that developed during 1970-1980 opened up the way for solutions that not only transgressed what the proponents in the 1970s presumably wanted to achieve; it could be argued that they materialised in forms that in relevant respects directly counteracted what the radical democrats had hoped for. ${ }^{96}$ To put it more bluntly: the left-inspired ideas of the 1970s and the 1980s paved the way for the reforms of the 1990s in questioning earlier, future-oriented, preparatory ideals. After 20 years of critique of the centralised, ideal-typical modern school system, the 'neoliberal' idea of a voucher system could be seen as one answer to the earlier criticisms. Was this not, in a relevant sense, in line with the 'here-and-now' and the anti-authoritarian critique? Could this not be seen as a response to the claim of letting the pupil exert a bigger influence over education and to a higher degree be considered an equal to the adults? Such a solution was hardly what the commissioners of the 1970s and 1980s had in mind, but that does not, as far as I can see, undermine the historical argument.

Closely intertwined with these changes, I would argue, is what appears to be the evanescence of substantial ideals that could guide the elevation of pupils in the educational system. ${ }^{97}$ The impulses giving rise to the anti-authoritarian critique of schools and defending

\footnotetext{
${ }^{96}$ This is in line with what Henrik Berggren and Lars Trägårdh argue from a more overarching perspective, and what Johanna Ringarp indicates from a school particular perspective, see: Henrik Berggren and Lars Trägårdh, Är svensken människa: gemenskap och oberoende i det moderna Sverige (Stockholm: Norstedts Förlag, 2015), 373-5; Johanna Ringarp, 'Utbildningspolitiken - från kommunaliseringen till PISA', in Det långa 1990-talet: när Sverige förändrades, ed. Anders Ivarsson Westerberg, Ylva Waldemarsson and Kjell Österberg (Finland: Boréa, 2014), 143.

${ }^{97}$ Something in a similar spirit to that depicted by Alasdair Maclntyre. In his seminal work After Virtue Maclntyre argues that without substantial, historically embedded ideas of what flourishing human life is, ie some form of dynamic and historically flexible theory of teleology, it will be difficult to avoid not only the moral philosophical dead-ends of our time, but also the rather gloomy outlooks of political life in the early twenty-first century, increasingly populated by a'democratized self, which has no necessary social content and no necessary social identity [and] can ... be anything, can assume any role or take any point of view', Alasdair Maclntyre, After Virtue (London: Bloomsbury, 2016), 37.
} 
the pupil's right to form her/his education for her-/himself both gravitate towards an idea of freedom as pure negativity; freedom is when each and every one decides for themselves. I am not saying that this was directly spelled out, or that this was the explicit aim of the reformers of the 1970s and 1980s. But I do claim that this is a plausible outcome of such critique. It is in this sense that I argue that the critique from the 1970s onwards paved the way for the introduction of a voucher system, which was explicitly based on a negative conception of liberty. Both the critique and 'the solution' tend towards the same vacuous individual; both point towards liberation from something - and for both the centralised state was the chief target.

In order to flesh out the further implications of this shift we can compare the two regimes of historicity with two different meanings of the term 'equality' that the French philosopher Marcel Gauchet has developed. ${ }^{98}$ One way to think of equality is to take the given society and the relationship between its different members as a point of departure. The individual is here thought of as a newcomer in a world already populated by others. Equality here assumes a comparative form in the sense that individuals are prepared for a life under currently dominant forms of hierarchies and distinctions. As such, they ought to be confronted with society in all its complexity with classes, hierarchies, etc. as soon as possible. This is a clash that for many will be violent; it risks becoming violent because it implies that the pupils will be aware of what they do not know but could become part of. ${ }^{99}$ It is considered necessary in order to provide the individual with the means required to influence society in the direction she/he finds best and to form her/his own life in the fashion she/he finds appropriate. By implication, this definition of equality is primarily forward-looking; the focus is on providing pupils with the means necessary to form their future life as citizens in society. This definition therefore seems to coincide with a future-oriented regime of historicity, and to have been the underlying idea in educational policies of the decades immediately following 1945.

A contrasting way of defining equality is to consider it a non-comparative concept. The state here treats each person as an equal when it respects each individual in her or his particularity. Each individual is here considered in her/his original independence. ${ }^{100}$ Equality is conceived of independently of the surrounding society. The good society is that which knows how to respect the particularity of each individual. In doing so, it facilitates a better, more pluralistic society. This definition of equality, with its focus on respecting the individual in its actual particularity, seems to expand notably in the policy documents between 1970 and 1990, coinciding with what Hartog calls a presentist regime of historicity.

As mentioned in the introductory pages, Hartog himself relates the shift in the 1970s to the economic changes of that time. Besides the gloomy outlook that the dissolving of Bretton Woods brought about, Hartog emphasises that 'le rôle moteur' behind the steadily inflating present in the 1970 s was the ever-increased demands of the consumer society. ${ }^{101}$

\footnotetext{
${ }^{98}$ Marcel Gauchet, La démocratie contre elle-même (Paris, Gallimard, 2002), 140-6. The ensuing account is taken from the pages indicated.

${ }^{99} \mathrm{~A}$ form of reasoning where Freud's reflections on sublimation seem to hover in the background, see: Sigmund Freud, Beiträge zur Psychologie des Liebeslebens (Leipzig, Wien \& Zürich: Internationaler Psychoanalytischer Verlag, 1924), $27-8$. ${ }^{100}$ Gauchet, La Démocratie contre elle-même, 141.

${ }^{101}$ Hartog, Régimes d'historicité, 156. For a more extensive discussion of how these economic changes relate to other societal tendencies, see: David Harvey, The Condition of Postmodernity (Oxford: Blackwell, 1990), 284-307. As regards the relationship between these changes and their repercussions on the role of knowledge and education in late modern society, few texts have been more influential than François Lyotard's report from 1979; see: François Lyotard, 'Rapport sur les problèmes du savoir dans les sociétés industrielles les plus développées', https://www.cse.gouv.qc.ca/fichiers/documents/publications/ ConseilUniversite/56-1014.pdf (accessed August 5, 2017).
} 
This follows the argument of Marx-inspired anthropologist and geographer David Harvey, who has convincingly shown how new forms of ephemeral consumer goods, most notably services, expanded rapidly during this time. Apart from opening up new spheres of society to marketisation, this also made possible a substantial acceleration of turnover time in production. Harvey characterises this as a 'time-space compression'. ${ }^{102}$

Without denying the relevance of these exogenous forces, the movements outlined above also indicate notable currents of continuity within and alongside the changes. I have focused on how the present has successively expanded at the expense of the past and future, and how this shift seems to be intertwined with a new form of equality and a predominantly negative form of liberty. But the backdrop, the normative framework, against which these changes emerged was the desire to bring about a 'democratisation of the Swedish school system. ${ }^{103}$ This dynamic, the transforming - indeed, perhaps even revolutionary - force of democratisation does not point towards Marx, but rather to a thinker who rarely appears in the Swedish context, namely Alexis de Tocqueville. However, reflecting on the explanatory force of his analyses of a democratic society for understanding the post-war educational reforms falls beyond the remit of this paper. That work is yet to be done.

\section{Disclosure statement}

No potential conflict of interest was reported by the author.

\section{Notes on contributor}

Tomas Wedin is a doctoral student at the Department of History of Ideas, University of Gothenburg. In his dissertation, he focuses on temporal dimensions and political ideals (as well as the intersections between the two) in educational reforms in Sweden during the post-war period. His research interests include political theory, history of education and history of political ideas. Between January 2016 and June 2017 he did a PhD exchange at École des hautes études de sciences sociales (EHESS) in Paris.

${ }^{102}$ Harvey, The Condition of Postmodernity, 284.

${ }^{103}$ SOU 1948:27, 1. 
Appendix II: The Paradox of Democratic Equality: On the Modified Teacher Role in Post-War Sweden 



\section{The paradox of democratic equality: on the modified teacher role in post-war Sweden}

\section{Tomas Wedin}

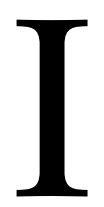

$\mathrm{n}$ the last decade, a number of studies have been published relating the in media highlighted problems of the Swedish school to the cluster of reforms launched around 1990. It has been pointed out that, e.g., the municipalization of the school, the introduction of a management by objectives as well as an educational system structured by a voucher model, all carried out in the years around 1990, substantially have contributed to the current problems in Swedish schools. ${ }^{1}$ As has been shown in a number of studies, the ideas permeating the reforms are not specific to the educational sector, but can be related to other societal reforms aiming at increasing decentralization as well as a further market orientation. ${ }^{2}$

A change intimately related to these transmutations is the deterioration of the status of teachers during the period, by some researchers described as a process of increasing

${ }^{1}$ SOU 20I4:I 5, p. 308ff; Gustavsson, Sörlin and Vlachos, 20I6, p. I $27 f f ;$ Stenlås, 2009.

2 Östberg and Andersson, 20I3; Ringarp, 201 I. 
deprofessionalization. ${ }^{3}$ A hereto related phenomenon are the shifts that have taken place concerning the perception of the teacher's task; as the historian Niklas Stenlås has pointed out, this is expressed in the more general questioning of the teacher as an authority. In its place, an ideal has been developed where the advocates have "sought to replace transmission of knowledge with applicability and care". ${ }^{4}$

It is against this backdrop that I here wish to highlight a number of crucial aspects of the modifications that the teacher's assignment underwent during the period 1945-2000. By dint of mobilizing the from Alasdair MacIntyre borrowed concept of "character", as well as the concept of "the social" by Hannah Arendt, I will attempt to narrow down previously overlooked aspects of these changes. I argue that the strong pupil-centered education, of which the introduction of the voucher system was a manifestation, can be related to a successively modified definition of the teacher's task since the school commission of 1946.

The problem will be assessed by answering (i) how the idea of what teachers are expected to do has changed, and (ii) how different organizational changes can be understood as implicit shifts in the teacher's task. The purpose hereof is to illustrate how the

\footnotetext{
${ }^{3}$ Broady, Börjesson, Bertilsson, 2009, p. 7-18; Stenlås, 2009; Stenlås, 20 I I Hasselberg, 2009; Albäck Öberg, Bull, Hasselberg, Stenlås, 20 I 6.

4 “[...] strävat efter att ersätta kunskapsförmedling med tillämplighet och omsorg”, Stenlås, 2009, p. 93. Compare also: SOU 20I 4: I 5, p. 349, 352. Regarding the school's changes in a "therapeutic" direction, there is today a vast amount of studies. Historically, this tradition can be traced to the I960s in North America with psychoanalytically-inspired thinkers like sociologist Philip Rieff and later, psychologist Christopher Lasch, see above all: Rieff, I966; Lasch, 1979. Among the more salient contemporary representatives we find: Ecclestone, 2007; Ecclestone and Hayes, 2009; Furedi, 2004; Furedi, 2009; Smeyers, Smith and Standish, 20I0. For a more general social approach, inspired by the Marxist tradition, see also: Illouz, 2007. For studies especially about Sweden, see: Landahl, 20I 5; Irisdotter Aldenmyr, 2012.
} 
perception of reproduction of society through pre-university education (which henceforth interchangeably bluntly will be referred to as "school") has changed. ${ }^{5}$ School will here be understood as the bridge intertwining the past of a given society together with its future. The diachronic analysis of the changed role of teachers therefore aims primarily at shedding light on how school qua institution has changed. In relation to previous research, I maintain that organizational as well as content-related shifts in a mutually undergirding fashion successively have sapped the teaching profession throughout the post-war period. ${ }^{6}$ By implication, the theoretical concepts that I activate serve primarily to elucidate school as a political-theoretical problem out of a historical perspective.

In order to address these questions, I will use governmental reports [Statens Offentliga Utredningar] and bills related to the teachers training reforms in the post-war era. ${ }^{7}$ The former can, according to Finnish educational sociologist Hannu Simola, be characterized as authoritative texts. Their aim is to clarify and, sometimes, to influence the object of the investigation in a certain direction. Since they are usually the product of mutual adjustments between the different persons summoned to examine the problem - be they politicians or specialists - it is reasonable to assume that the most startling idiosyncrasies have been washed out. Bills on the other hand are directly governing policy texts, designed to be transformed into laws. ${ }^{8}$ These differences will here be of subordinated relevance; I shall rather read them, inspired by Arendt, as "frozen thoughts", which we can thaw up in order to

\footnotetext{
${ }^{5}$ As John Dewey reminds, the social fabric is not woven by itself; a society that does not work "on a massive transmission" of the core components of its culture can, regardless of how civilized it has been, "return to barbarity and cruelty", see: Dewey, I916, p. 3.

${ }^{6}$ Ringarp, 20 I i; Stenlås, 2009.

${ }^{7}$ More precisely six investigations and three bills.

${ }^{8}$ Semola, 2000.
} 
track social impulses in a diachronic perspective. ${ }^{9}$ Read as such, I understand them as the upshot of societal changes: as effects rather than causes.

This reading in combination with the relatively long timespan does not allow stronger empirical claims. Hence, rather than ascertaining how to think of educational historiography in the post-war period, my undertaking should be understood as an attempt to articulate new theoretical perspectives which, if convincing, could serve as sources of inspiration for further empirical studies. The decisive advantage of engaging with the topic in a slightly longer time perspective, is that it opens up for a more historically dynamic understanding of the changes around 1990 as well the current problems of the school.

I have chosen to fix my temporal limitation backwards to the school commission of 1946. This was the first time that the commissioners were instructed to query the issue of a specific teachers training program. ${ }^{10}$ Although the 1940s school commission was extensive and spurred the educational policy debate, it was first as a consequence of the 1946 commission that the ideas of a profound democratization were widely announced, not least due to the totalitarian experiences. ${ }^{11}$ The line of demarcation of the study frontwards in time is the new teachers training bill of 1999/2000, which has been chosen due to lack of space. $^{12}$

\footnotetext{
${ }^{9}$ Arendt, I97I, p. 43 I.

${ }^{10}$ I $948: 27$, p. xi. Although the extensive investigation that preceded the I 946 commission will not be left completely untouched but serve as a relief.

11 Östling, 2008.

${ }^{12}$ Notwithstanding the manifest changes in the latest wave of reforms between 2008-20II, I argue in an upcoming article that we, as to what concerns the issues here addressed, have good reasons consider these as a - in relevant respects - furthering of the dynamic here outlined, see: Wedin, 20I7a.
} 
A crucial shift that I narrow down is that teachers decreasingly was expected to prepare pupils for life in democratic society, and instead, to a growing extent, were expected to incorporate the latter into the democratic practices in school. This displacement can be understood as a partial expansion of demos, in which children and youths have been assigned a greater role. For the teaching assignment, this has meant that transmission of knowledge has been down-played and partly replaced by an individually adapted coaching, where pupils increasingly have been expected to learn how to learn (as in contrast to learning the propositional knowledge $\mathrm{x}$ ). ${ }^{13}$ This change, I contend, is congenial with what in institutional research is described as a general weakening of institutions in society. ${ }^{14}$

\section{Character}

In order to clarify this shift, I activate the MacIntyrian concept of character. In After Virtue, he extricates what he considers to be the dominant trait of modern society: a normative-practical dead end because of its inability to represent itself in teleological terms. ${ }^{15}$ One of the analytical instruments that he activates to highlight this shift, is the concept of character. ${ }^{16}$ The character differs from social roles, such as occupational roles, family roles, sports roles, etc., in letting personality traits and role fuse. We can thus, with our different personalities, play roles in different ways: that which defines the role is determined by the institutional context. This is not the case with the character. The latter is

\footnotetext{
${ }^{13}$ Which can be compared to what Thomas Ziehe describes as a general shift of the role of teachers in late modern society towards what he calls a "relationship worker". See: Ziehe, I993, p. I28.

${ }^{14}$ Zijderveld, 2000.

${ }^{15}$ A criticism that, clearly, he is not only one to have advanced. The reason for which I have chosen MacIntyre is rather the analytical concept that he mobilizes in his argumentation. The first edition was published in I98I.

${ }^{16}$ MacIntyre, 20I6, p. $32 \mathrm{ff}$. When discussing MacIntyre, it is on these pages that I draw.
} 
expected to incarnate both a certain role and a personality; the "social and the psychological type" thus coincides with the individual who embodies the character. ${ }^{17}$ The character can hence be comprehended as a "mask" through which the central principles of a society are mediated. ${ }^{18}$ A character can in this sense be understood as a kind of ostentatious definition of dominant ideals in a given cultural sphere; similarly to how we define red by giving examples of red objects, MacIntyre argues that different communities are distinguished by their culture-specific characters. ${ }^{19}$

Constitutive features of different societies during distinct epochs can thus be concentrated by analysing which roles that in a given society can be described as characters. As an example of characters in different societies, MacIntyre maintains that Victorian England could be characterized by the Public-School Director, the Discoverer and the Engineer. ${ }^{20}$ Another example is Germany during the time of Wilhelm II, which was embodied by characters such as the Prussian officer, the professor and the Social Democrat. Typical characters for late modern Western society are, MacIntyre argues, the aesthetic, the manager and the therapist. Specific for these latter characters is that they all consider the goals as externally given, and hence always focus on the means. ${ }^{21}$ Where the manager always sets the effectiveness of the business regardless of what is to be done effectively - in the first place, the goal of the therapist is to turn maladjusted individuals into wellfunctioning.

\footnotetext{
${ }^{17}$ MacIntyre, 20I6, p. 34.

${ }^{18}$ MacIntyre, 2016, p. 33.

${ }^{19}$ Of which does not follow that they would express the only standards, but the dominant ones.

${ }^{20}$ A Public-School is a private boarding school with a high or very high (depending on which one applies for) status. Some of the most renowned are Eton, Winchester and Rugby.

${ }^{21}$ Since the two latter clearly can be related to the school world, I have chosen to focus on these.
} 
Now, to this catalogue of characters, I would like to add the teaching ideal that emerged in the policy documents during the post-war era. The ideal teacher that appears in and between the lines of the school policy documents shares several characteristics with what in Sweden today in an anglicized form is called a coach: ${ }^{22}$

\begin{abstract}
A coaching communication at all stages will enable pupils and employees to grow and increase their commitment and motivation in school. As a consequence, the joy of work will also increase. Coaching is always based on the current situation and looks forward. It is also assumed that it is the individual self who is in possession of the answers and solutions. Coaching attracts the best of you, raises awareness, detects inherent potentials, develops strengths, and enhances self-esteem. Focus is shifted from problems to opportunities and school is better equipped to handle challenges ${ }^{23}$
\end{abstract}

As we will see below, the teaching assignment was gradually redefined in course of the period towards the ideal outlined for school coaches above. I argue, moreover, that these transmutations of the expected task of teachers should be comprehended as an expression of a growing skepticism against institutions in general. Analyzing the teaching ideal as a character is particularly well suited since their task - qua incarnation of, speaking with Louis Althusser, the primary ideological state

\footnotetext{
${ }^{22}$ The definition is taken from the enterprise Skolcoacherna, which offers coaches to public activities, private companies and private individuals.

23 "En coachande kommunikation i alla led får elever och medarbetare att växa och ökar engagemanget och motivationen i skolan. Då ökar också arbetsglädjen. Coachning utgår alltid från dagens situation och blickar framåt. Man utgår också från att det är människan själv som sitter inne med svaren och lösningarna. Coachning lockar fram det bästa hos dig, ökar medvetenheten, upptäcker inneboende potential, utvecklar styrkor och stärker självkänslan. Fokus flyttas från problem till möjligheter och skolan blir bättre rustad att hantera utmaningar." http://www.skolcoacherna.se/index.php/coachandekommunikation.html.
} 
apparatus of society - reflects the way society both establishes, by dint of hereby pointing out a direction, and reproduce itself. ${ }^{24}$

\section{School as institution}

The term institution is attributed, depending on context, different meanings. In the leading Swedish encyclopedia Nationalencyklopedin, the term is defined as "the name of norms and rules that structure human actions" and therefore "nearly synonymous with established convention", regulated in form of laws as well as in form of informal practices and traditions. ${ }^{25}$ Examples of such institutions are family, science and health care each and one of them traversed by their specific logics and goals. Thus, within health care the overarching aim is to nurture and heal, whereas the family is expected to furnish a first micro community for the individual to orient, and in science it is the quest for truth that is expected to orchestrate the activity.

For the problem that I am trying narrow down, there are two other institutions that will be of particular interest: state and market. ${ }^{26}$ Since the emergence of democratic society, these both have, ideally, been associated to two different logics. The state should be permeated by, and pursue a logic where the common good is put in the forefront. This is what I shall call the public logic. The market, on the other hand, is characterized by a privately-oriented logic where people - of flesh and blood or in legal form - meet to satisfy their particular interests. As a hybrid between on the one hand the public and on the other hand the private, a third

${ }^{24}$ Althusser, 1970. The distinction is inspired by the for Cornelius Castoriadis' thinking central concept pair instituélinstituant and the dialectics between these two, see, for example, 'Pouvoir, politique, autonomie' in: Castoriadis, I990.

25 Nationalencyklopedin online, NE.se/institution (2016-го-IO). In addition to this overall dimension of the term, it can of course be used in other ways, but I will use this definition as my point of departure.

${ }^{26}$ For a clarifying discussion about how both of these have characterized the school debate, see: Englund, I993). 
analytical category, inspired by Arendt, is the social. ${ }^{27}$ What characterizes the social is that that which is pursued in private becomes a public affair. ${ }^{28}$

However, from the fact that different institutions operate according to different rules, it would be invalid to infer that they would act independently of each other; that, for example, the market, both in theory and in practice, has its logic and science has its own, does naturally not prevent them from impinging on each other. ${ }^{29}$ In recent decades, this has been manifested in Sweden as well as in all other Western countries by the fact that the market logic in a conspicuous fashion has rubbed off on other areas, not

\footnotetext{
${ }^{27}$ Which should not be confused with the very general definition of "social institutions" above. When writing "inspired", I want to emphasise that Arendt's own definition and application of the term is not coherent: her usages of the term in 'Reflections on Little Rock" (Arendt, 2005), Arendt, I997, and, e.g. 'Crisis in Education' (Arendt, 2006), point in different directions.

${ }^{28}$ Arendt, I997, p. 68ff. The two spheres that Arendt writes about is public and private. As the market is penetrated by an institutional logic according to which the actors are expected to look after their private interests, I have, in order to render Arendt's analytical distinction applicable, chosen to equate the market as an institutional logic with the logic applying in the private sphere. Historically, Arendt believes that this new form of publicity was developed in parallel with the rise of territorial states in the Late Middle Ages. In full, however, this new logic blossoms in connection with the emergence of modern society during the rath century. In order to highlight certain relevant educational policy displacements during the post-war period, I will use social and public as relative concepts, i.e. as two ends on a scale, which can help us unveil new perspectives on dislocations in the educational policy.

${ }^{29}$ This should not be considered as a standpoint for either a stronger distinction of the spheres, such as the one described by Daniel Bell, or the Hegelian/Marxist totality idea. For two clarifying examples of this, both focusing on the current period, see: Bell, 1976; Jameson, I992. For another, besides Jameson, and more recent vindication of an integrative approach, see: Fraser, 20I4.
} 
at least the scientific community and the health sector. ${ }^{30}$ These distinctions are rough, but their purpose is primarily heuristic: by separating them in this artificial way we can - or so I contend improve our understanding of policy changes over time.

The institution at center of this paper is the undergraduate educational system. In a very general sense, school aims at introducing children and young people to the world they are born into. With the expansion of the establishment of the public school in 1842, more and more tasks have successively been shifted from the family, the private teacher, the church, etc. to the school. As a typically modern institution, it has since the beginning been characterized by various institutional arrangements with their respective logics. Where school is exactly placed between the private and the public sphere is therefore an open question. Parallel with preparing students for a life among equals in a shared public sphere, it is not fully part of this sphere, as it inevitably is structured by the unequal relationship between those expected to be introduced and those who introduce. ${ }^{31}$ It therefore constitutes a specific space between the two other spheres. ${ }^{32}$ By showing how the difference between teachers and apprentices during the postwar period shrank, and how our understanding of this change could be furthered by activating the social as an analytical category, I will expose how this room "in-between" changed during the period.

\footnotetext{
${ }^{30}$ Ivarsson, Waldemarsson and Östberg, 20I4; Andersson and Östberg, 20I3; Albäck Öberg et al., 20I6. On school in particular, see: Lundahl, 2002; Baggesen Klitgaard, 2007; Bunar, 2010.

${ }^{31}$ This uneven relationship is justified by the fact that it is just a limited time it exists, see: Arendt, 2006, p. I9If. For the sake of clarity, it should be added that this unequal relationship holds whichever pedagogic regime that happens dominate, since it will always be planned and thought out in advance by the adults. For a recent attempt to revitalize Arendt's approach to this theme, see: Bergdahl and Langmann, 2017.
}

${ }^{32}$ Arendt, 2006, p. I 85. 


\section{The teacher in the emerging comprehensive school}

The 1946 School Committee was appointed to prepare a thorough reform of the Swedish educational system up to the upper secondary level. Although the 1940s school inquiry had hardly completed the approximately 4,000 pages of material, divided into not less than 20 reports, the newly-elected Social Democratic Government under Per Albin Hansson chose to summon a new commission. The reason was that:

[...] a comprehensive planning work for coming reforms in other areas of society has been implemented and that it seems desirable to evaluate the demands, that school will encumber on state finances. In addition, there is a strong increase in nativity, which necessitates extensive measures regarding teacher training, school building, etc., which should be integrated into a defined plan for the continued development of the educational system. ${ }^{33}$

In addition to these practical reasons, the importance of elucidating the forthcoming educational reform "in more general terms" was stressed. ${ }^{34}$ This directive should be read in light of the forces who, in particular within the Social Democratic Party, wanted to replace the actual parallel educational system - "a class society in miniature" - with one school enrollment for all. ${ }^{35}$ With

33 “[...] ett omfattande planläggningsarbete för kommande reformer på andra samhällsområden verkställts och att det synes önskligt att i ett sammanhang få pröva jämväl de krav, vilka skolväsendet kommer att ställa på statsfinanserna. Härtill kommer den starkt ökade nativiteten vilken nödvändiggör omfattande åtgärder beträffande lärarutbildning, skolbyggande etc., som böra inpassas i en uppgjord plan för skolväsendets fortsatta utbyggande." SOU I948:27, p. x.

34 “[...] ur mera allmänna synpunkter”, Marklund, I974, p. 44.

35 “[...] ett klassamhälle i miniatyr", Erlander, I973, p. 233. However, as Petter Sandgren has emphasized, the statement needs qualifying. As the importance of the secondary grammar school in $19^{\text {th }}$ century has diminished in conjunction with the emergence of the unitary school, Sandgren convincingly argues that the economic haute bourgeoisie has succeeded in maintaining a unsurpassable - consecrated to use Sandgren's Bourdieu-inspired conceptual apparatus - educational privilege in form of private boarding schools with their for the vast majority of families 
the democratization of society, the educational system should also be democratized; and here, the school fell short, as it "not entirely had managed to keep up with the societal development". ${ }^{36}$

In addition to reviewing the forms of school, the commission was also assigned to examine the methods of education and training. The investigators were thus instructed to overview what kind of education forthcoming teachers should be given. Bearing witness of the importance ascribed to the education of teachers, is the commissioning of a specific delegation aiming at "investigating issues in connection with the establishment of a first teachers training of education" (whereby those aspects that already had been announced by the 1946 Commission were further developed). ${ }^{37}$ As part of the upbringing and transmission of knowledge, the commissioners also emphasized the importance of having teachers "developing the ability of disciples to work on their own and to plan their work". ${ }^{38}$ This new, progressive approach was considered a sharp contrast to the still prevailing methodology, which featured "a burdensome legacy of the school

unaffordable annual fees, see: Sandgren, 20I5, p. I3 I-I32. In addition, the efficiency-based arguments for a better functioning meritocratic system should be highlighted, according to which the one best suited to a given position really ends up there rather than anyone else just because the school's selection system does not work optimally, see also: Lindensjö and Lundgren, 20I4, p. 57.

36 '[...] inte helt kunnat hålla jämna steg med den samhälleliga utvecklingen'. SOU 1948:27, p. I. In his memoirs, Tage Erlander argues in the same way, see: Erlander, I973, p. 237. The employment of a new commission should be understood in light of the deep split within the previous committee, especially regarding issues related to cohesion and differentiation in a reformed educational system, see: Lindensjö and Lundgren, 2014, p. 49.

37 “[...] utredning av frågor i samband med inrättandet av en första lärarhögskola”. SOU I952:33, p. vii.

38 “[...] utveckla[r] lärjungarnas förmåga att arbeta på egen hand och planlägga sitt arbete”. SOU I948:27, p. 352. 
of the Middle Ages and the former bureaucratic state school". ${ }^{39}$ As long as this "question-and-answer" method governs pupils activities, it tends to create "lack of independence, belief in authority, passivity"; the method, they claimed, is "to its internal purpose [...] authoritarian". ${ }^{40}$ It is therefore now, they continue, time to replace the "school of authority" with the "school of activity". ${ }^{41}$

As the educational historian Gunnar Richardson writes, the practical prescription ordained was a working school and group work; the modern teacher should hereafter be formed into a kind of supervisor, a "primus in the class work community". ${ }^{42}$ The idea is that pupils should be able to do a job in school that coincides with their interests, where he or she participates in the configuration of the tasks themselves. In this regard, it was considered crucial that teachers could see each individual disciple in her unique situation. These new, non-authoritarian, more democratic and individualized methods were desirable because they were thought to best be able to further the democratic landscape that successively was taking shape.

Parallel to these requests, the investigators also emphasize the importance of teachers themselves having the qualities they want to inculcate among pupils; that an aesthetic sensitivity has a "refining effect on the personality's formulation is generally" recognized. ${ }^{43}$ It is therefore of importance, the investigators go on, that school take this into account to a greater extent than hitherto. However, although the importance of new methods applied in

39 "[...] ett betungande arv från medeltidens och den gamla ämbetsmannastatens skola”. SOU I948:27, p. 5 .

40 “[...] fråga och svar [...] osjälvständighet, auktoritetstro, passivitet [...] till sin inre syftning [...] auktoritär”. SOU I948:27, p. 5 .

41 “[...] auktoritetsskolan [...] aktivitetsskolan”. SOU I948:27, p. 5, 354.

${ }^{42}$ Richardson, I983, p. 87.

${ }^{43}$ [...] förädlande verkan på personlighetens daning är allmänt”. SOU I948:27, p. 352 . 
school was emphasised, there still seem to be some fairly clear boundaries implicated for what, according to at the time prevailing standards, was considered to be good taste and not. ${ }^{44}$ The dichotomy between the school of authority (the ancient and undemocratic) versus the activity school (the democratic and progressive) thus accommodated several dimensions. "Already Plato pronounced", the commissioners write, "that education and teaching is the spiritual contact between two personalities, not just the transfer of information from a teacher to a disciple." ${ }^{45}$ In this passage another picture emerges of how the commissioners argued in their criticism of a (imagined) sterile mediating teacher.

The transmitting dimension is, as in the "traditional" school, prevalent here as well: "the teacher makes him familiar with modes of thinking". ${ }^{46}$ It is rather the attitude and view of what is

\footnotetext{
${ }^{44}$ SOU I948:27, p. 3 of.

45 "Redan Platon uttalade, att uppfostran och undervisning är själslig kontakt mellan två personligheter, ej blott ett överbringande av upplysningar från en lärare till en lärjunge.” SOU I948:27, p. 355. The chosen quote opens up for several possible interpretations. An association that it arouses, of which there are more in the investigation, are the clear traces of idealistic thinking that emerged at this time, but disappeared from the end of the I940s onwards. Another possible link is Plato's own ideas about teaching, which in the form of the Maieutian method have been cherished also after Plato, in virtue of symbolising The Tradition, had been cleared out of educational policy documents. These are, however, not traces that I will pursue here. For a discussion about how German idealism crumbled away in Swedish educational policies after World War II, see: Östling, 2008.
}

46 “[...] traditionella [...] läraren gör honom förtrogen med tankegångar". SOU I948:27, p. 27,355 . It is worth noting in parentheses how this emotionally charged way of talking about the teaching situation differs from the criticisms of emotional and / or therapeutically stressed teaching which several researchers think they can distinguish in educational systems in different states. As the intellectual historian Thomas Karlsohn points out, it is very doubtful how fruitful it is to put emotions against the never-decreasing rigor of reason in the educational context. The relevant question instead, as Karlsohn points out, concerns the question of what kind of emotions we want to penetrate all those active in teaching (at all 
happening that is being emphasized. Teacher's influence over pupils thus occur as much in the dynamics in relation to the pupil that the teacher as a buman being can mobilise, as via his'/her's knowledge of the subject. Therefore, the teacher's need for at depth knowledge as well as interest in cultural issues seem to be interdependent in the report; the teacher must not, "to use Plato's words [...], feel like a retail seller of those goods, of which the soul is nourished." 47

The idea of the teacher as a supervisor in an increasingly individualized education (where pupils interests are given a greater importance) should also be understood as a strategically important part of the argumentation for the comprehensive school. ${ }^{48}$ Without the promotion of an individualized teaching, it would have been even more difficult to convince the opponents of the comprehensive school about its practical feasibility, in particular

levels). What emotions do we want, differently expressed, to awake and encourage in those who are to be taught as well as those who shall teach? See: Karlsohn, 20I6. For further discussions about emotions and education and the criticism of what some refer to as a therapeutic turn, see note 4 above.

47 "[...] för att använda Platons ord [...] känna sig som en minuthandlare i de varor, av vilka själen har sin näring”. SOU I948:27, p. 357. Based on these carefully chosen quote, the reader can get the impression that Plato was the commissioner's main source of inspiration. However, the importance of Plato should not be exaggerated; in total, he is mentioned four times in the investigation, which all in all is 56I pages long.

${ }^{48}$ The comprehensive school gradually replaced the former parallel school system, where the peasants and workers' children tended to go to the seven-year primary school while the children from better-educated environments went to the secondary grammar schools (most of them were placed in the more important cities). The secondary grammar school was divided into two separate stages after the I905 Statute of Secondary Grammar School [Läroverksstadga]. The lower form of junior secondary school [Realskola] was created for the first six years, which later, at the I927 secondary grammar school reform, was transformed into a 4respectively 5-year-programe. The second and higher stage was called upper secondary school [gymnasium] and was four years long. 
regarding the purported risk of levelling that several, especially secondary grammar school teachers, warned for. Therefore, the individualized teaching was, in order to borrow Richardson's wording, a sine qua non for the introduction of the comprehensive school. ${ }^{49}$ Individualization was thus expected to be pursued with the aim of allowing each pupil to work in accordance with the particular pace that her's or his' capacities allowed for.$^{50}$ As part of the endeavour to individualize teaching, the commissioners also suggested a coherent class teacher education far up in the ages (meaning until they had reached the age of 13), as this "enables better individual care of the pupils". ${ }^{51}$

Regarding the differences between the various categories of teachers, the commission wanted the "actual vocational training to be largely shared by all categories of teachers". ${ }^{52}$ In addition to purely practical adjustments, i.e. through the increased opportunities for teachers to retrain, I maintain that this effort should also be understood as a desire to not only formally, but also as to what regards the content, abolish the parallel educational system. On another ideological level, this should, furthermore, be understood as a desire to create an institutional framework for the cultivation of progressive pedagogics that educational reformers wanted to achieve; the teachers' training college should, as the investigators express it, be "hearths for progressive education". ${ }^{53}$

\footnotetext{
${ }^{49}$ Richardson, I983, p. I 54. See also: SOU 2014: I 5, p. $327 \mathrm{f}$.

${ }^{50}$ SOU I948:23, p. 353 .

51 "[...] möjliggör en bättre individuell omvårdnad om eleverna”. SOU I948:27, p. 8 .

52 “[...] egentliga yrkesutbildningen i stor utsträckning bör göras gemensam för alla lärarkategorier”. SOU I948:27, p. 363 . Compare also with the text that follows under the heading "Principle of Sharedness in the Actual Vocational Education" in the Teachers Training Commission, SOU I952:33, p. 7 ff.
}

53 “[...] vara härdar för progressiv pedagogik". SOU I 948:27, p. 4IO. The formulation is then cited again in the investigation of the establishment of the country's first teachers training college, I952:32, p. 24. The desire to 
However, when the bill in which guidelines for the comprehensive school was presented, the tone was far more unobtrusive than in the report. ${ }^{54}$ In stark contrast to the investigators' expectations, the right-wing politician Georg Andrén described it as a "progressive gliding from a dogmatic utopia to experience"; the new democratic methods advocated in the investigation came to play a much more modest role in the bill. ${ }^{55}$ As an explanation for this displacement, Richardson points to criticism of the proposal from various evaluation instances and media as well as the increasingly acute shortage of facilities and teachers. ${ }^{56}$

As we shall see, the lack of teachers was a reality that would characterize the educational policy debates in other respects as well during the first decades after the war. But whereas the actual reforms proved more modest than the visions here, the gap between visions and reforms - regarding the desire to democratize the school - would attenuate from the 1970s and onwards.

integrate teachers at all levels of the comprehensive school in one single school should also be related to a more general endeavour to dissolve boundaries, or isolation as the investigators formulate it, between different professional groups in society. To this subject, the commissioners return in the investigation. The endeavour to improve practical knowledge vis-à-vis theoretical is an aspect that characterizes post-war education policy. Among the more pronounced expressions, the 1977 college reform can be mentioned as well as the theory of so-called socio-cultural learning, which since the I 990 s has had a huge impact on teacher education all over Sweden. For examples hereof in this investigation, see: SOU I948:27, p. 362 f. Similar arguments are also presented in the Teachers Training Commission presented shortly thereafter: see SOU I952:32, p. I9f.

${ }^{54}$ Bill I950:70.

55 “[...] fortskridande glidflykt från en dogmatisk utopi till erfarenheten". Georg Andrén's contribution in the first chamber of 1950, no. 23, I4, quoted in Richardson, I983, p. I74.

${ }^{56}$ Richardson, I983, p. I7Iff. 


\section{Towards a further democratization of the school}

In 1965 , the 1960 teachers training experts presented their report. Concerning the questions addressed here, the tone does not deviate considerably from the findings of the 1948 commission (nor to the hereto related Teachers Training Report of 1952). As the report was presented, it had already been agreed upon that a comprehensive school would be established. The decision was taken in unison by the parliament in 1962. The commissioners task was to "carry out investigations concerning the organization of the subject- and class teacher's education, etc." 57

In line with the 1948 report, the commissioners demanded that "measures were taken to bring teachers closer together". ${ }^{58}$ The distinctions introduced between different departments in conjunction with establishing comprehensive school, the junior-; intermediate; and senior level, were considered far too closely related to the previous structure. Not at least was this considered so with regard to the clear boundaries between class teachers (16 ) and specialist subject teachers ( $7^{\text {th }}$ grade and upwards); "by and large", the investigators argued, "do the current forms of school rest on a specialization ideology, which belongs more to the older than the new educational system". ${ }^{59}$

The comprehensive school rests on other foundations. In the limelight is the upbringing of individual pupils. This ideal, the investigators stress, rests on three fundamental principles. The first is that the development and needs of the "individual" must be the point of departure for teachers. ${ }^{60}$ The second principle is that the

\footnotetext{
${ }^{57}[\ldots]$ verkställa utredning rörande ämnes- och klasslärarutbildningens organisation m.m.”. SOU 1965:29, p. 3.

${ }^{58}[\ldots]$ åtgärder vidtas för att föra även lärarna närmare varandra”. SOU I965:29, p. I80.

59 “[I] stora stycken vilar nuvarande utbildningsformer på en specialiseringsideologi, som mera tillhör det äldre än det nya skolsystemet”. SOU I965:29, p. I75.

${ }^{60}$ SOU I965:29, p. I70.
} 
latter should "consider the pupil in an overall perspective". ${ }^{61}$ The essential is thus the whole, and not how pupils perform in individual subjects or parts of subjects. The third principle that should guide the teacher's assignment is that pupil's "development is continuous and not at intervals with forms and stages like artificial positions of states of rest." 62 Together, these three principles narrow down two significant educational policy changes during the post-war era.

The first is the increased emphasis of the individual as the obvious starting point of education. ${ }^{63}$ The second is a movement towards a disintegration of borders appearing in three different forms: a dissolving of borders between practical and theoretical work, between different departments (of which the distinction between class- and - subject specialist teacher is one relevant aspect), as well as the approaching between pupils and teachers. It is on the latter two that I will focus here.

The more uniform teachers training education that was sought for was an expression of the more extensive tendency to create a more democratic school. In addition to the pursuit of having class teachers approaching subject specialist teachers, this would also be reflected in the ambition to downplay differences between manual and intellectual work:

In the era of automatization, it is not as before possible to distinguish between manual and intellectual work. Likewise, it is becoming impossible to see academic disciplines and job training subjects as mutual exclusives. The job training subjects contains subject-theoretical moments, and academic subjects focus on needs of labour market, etc. Besides the above-mentioned cleavage between class teacher and subject teacher in the traditional teachers training, further cleavages must be considered, which strikes a

61 “[...] beakta hela eleven”. SOU I965:29, p. I70.

62 “[...] utveckling är kontinuerlig och inte språngvis med årskurser och stadier som konstlade vilolägen”. SOU I965:29, p. I70.

${ }^{63}$ For studies of the individualization process, see: Giota, 20I3, Vinterek, 2006; Wedin, 20I7b. 
discordant note with school's ambition of an all-round education of the personality, namely the dualism between theoretical and nontheoretical paths, as well as an artificial division of content and teachers in theoretical subjects, practical subjects and job-training subjects. $^{64}$

The tone is on the lines of the reforms that later on were carried out also at universities with the 1977 colleges reform. ${ }^{65}$ But, as indicated by the quote, this desire was clearly not exclusively motivated by an equality-inspired willingness to downplay differences between workers and academically educated persons: out on the labour market there are no artificial divisions between practice and theory.

Beyond the needs of the external interests and efforts made to advance equality, we glimpse the needs that the rapidly expanding educational system itself generated: "Almost all over the world, the teacher problem is one and the same: the teachers are too few and the teachers in existence have an inadequate education." 66 This is why, as Department Director Ragnar Edenman (Social Democratic Party, henceforth just " $S$ ") writes, it is of importance that the commissioners examine the question of how teachers training could be designed, so that teachers gain competence to

64 "Det är i automationens tidevarv inte heller möjligt att som förr särhålla kroppsarbete och tankearbete. På samma sätt blir det omöjligt att se läroämnen och yrkesämnen som helt sidoordnade. Yrkesämnena innehåller ämnesteoretiska moment, läroämnena inriktas på speciella avnämarbehov o. s. v. Till den ovan påtalade klyvningen klasslärareämneslärare i den traditionella lärarutbildningen kommer sålunda andra former av kluvenhet, som inte rimmar med skolans mål om allsidig personlighetsfostran, nämligen dualismen mellan teoretiska och icketeoretiska studievägar och en konstlad uppspaltning av lärostoff och lärare på läroämnen-övningsämnen-yrkesämnen.” SOU I965:29, p. I7.

${ }^{65}$ Richardson, 2010, p. 249.

66 "Över praktiskt taget hela världen är lärarproblemet ett och detsamma: lärarna är för få och de lärare som finns har en inadekvat utbildning.” SOU I965:29, p. I 5 . 
teach in more subjects than they currently are ${ }^{67} \mathrm{With}$ regard to the role of teachers in classrooms, it did not deviate noticeably from the commission of 1946: the teacher was expected to assume the role of a supervisor as well as leaving more room for pupils to follow their interests at the same time.

Another central aspect concerned how the nature of knowledge was considered, as well as the transmission of the same. We can here discern some relevant changes of nuances between the two investigations. In the 1946 commission, the importance of inculcating a respect for "the highest values of culture" and, ultimately, "love for the studies" were emphasized. ${ }^{68}$ At the same time, the commissioners underline, it is the responsibility of teachers to rouse an understanding for:

[...] that the cultural heritage is alive, that it is constantly developing and that they themselves have a task of contributing to the furthering of culture. This means, among other things, an insight into the relativity of school skills: as research progresses, the recognized scientific truths might eventually get in need of adjustment. $^{69}$

When the Teachers Training Commission of 1960 presented their report, the tone was somewhat different. Under the heading of "knowledge and skills" (kunskaper och färdigheter), the commissioners call to mind that in the new curriculum for elementary schools, Läroplan för grundskolan 1962 (Lgr 62), it is stated that teaching shall promote pupils' development and

\footnotetext{
${ }^{67}$ SOU I965:29.

68 “[...] kulturens högsta värden [...] kärlek till studier”. SOU I948:27, p. 27.

69 “[... [ kulturarv är levande, att det ständigt utvecklas och att de själva har en uppgift att fylla i arbetet på kulturens vidareutveckling. Detta innebär bl. a. en insikt i skolkunskapernas relativitet: i och med att forskningen går vidare blir de en gång erkända vetenskapliga sanningarna så småningom i behov av justering. SOU I948:27, p. 27.
} 
"thereby communicate knowledge". ${ }^{70}$ The acquisition of knowledge thus appears to have become an instrument for the development of the individual. In order for the teachers to succeed in their work, it is crucial that the student "should feel" that she constantly advances and develops; "the outlook of the content of teaching has thus been relativized" ${ }^{71}$ It is now more important that students learn to orient themselves among all new things with which they are constantly confronted in their lives than to acquire a specific content, since the latter may anyhow have "become peripheral and obsolete tomorrow". 72 Teaching learning techniques is therefore of "increasing importance"; something which, the commissioners add, in turn further strengthens the dissolving borders between theoretical and vocational subjects: "learning actual knowledge shall primarily aim at providing a capacity to orient". ${ }^{73}$

At the same time, immediately afterwards, there is a plea for teachers to awaken a deeper understanding for the role of aesthetics in life and to "stimulate taste and a sense of beauty" among pupils. ${ }^{74}$ In this regard, the similarities between this report and the commission of 1946 should be clear. As stated above, we can nevertheless discern certain relevant displacements towards a relativization of the content, implying a shift of emphasis where the forms of teaching increasingly were stressed at the expense of the expected impartation of a given content. This is a shift that, as we shall see, would be further undergirded over the years.

\footnotetext{
70 “[...] därvid meddela kunskaper”. Lgr 62 quoted in SOU I965:29, p. 82.

71 “[...] kunna känna [...] synen på undervisningens innehåll har alltså relativiserats". SOU I 965:29, p. 83 .

72 “[...] blivit perifert och föråldrat”. SOU I965:29, p. 83.

73 "[...] ökad betydelse [...] inlärandet av aktuella kunskaper skall främst syfta till att ge färdighet i att orientera sig [...]. SOU I965:29, p. 84 .

74 “[...] uppöva smak och skönhetssinne”. SOU I965:29, p. 84 and 88.
} 
However, it should be emphasized that we find similar relativizing impulses (albeit less emphasised) already in the report of 1940. Here as well, the commissioners claimed that school was undergoing a development "which in its entirety means nothing less than a revolution"; a revolution in which the older "cram school" was replaced by the elaborative so-called working-school methods. ${ }^{75}$ In this respect, we have good reasons to trust Gösta Bagge, the former ecclesiastical minister of the Högerpartiet (the at the time Conservative Party), and the other commissioners; given the changes regarding how the reproduction of society and the allowance of some form of continuity over time that during this period was realised throughout the educational system, it does not seem unjustified to speak of a veritable revolution.

The criticism of the "cram school", which was articulated already by the commission in 1940, is by now a commonplace: there one does not learn for life but to pass your degree. The commissioners then haste to add that parts of this criticism are clearly excessive and sometimes based upon an inadequate knowledge of the work in school. It does, nevertheless, "usually represent experiences which, in the event of a general review of the educational system, should not be left unattended". ${ }^{76}$ It is the replacement of this school with a new, where the laboratory working methods are at heart of the activity, that the commissioners recognize as the revolutionary element. ${ }^{77}$

75 “[...] som i sin helhet innebär ingenting mindre än en revolution [...] pluggskolan". SOU I944:20, p. 5I, 55. Cram school [pluggskolan] is put in quotation marks in the actual report as well.

76 “[...] representera de dock i regel erfarenheter, som vid en allmän översyn av skolväsendet icke böra lämnas obeaktade”. SOU I944:20, p. 52.

${ }^{77}$ As I write above, the commission's approach to the method in question seems to have been limited to be precisely a method. The commissioners write on the same page that even "tests and exams are, if they are naturally inserted in a well-planned and balanced education, not harmful; in the continuing education of different courses of life, such tests often play a crucial role, and similar situations are often met out in life. School should let children be children and allow youths to enjoy their youth, but it 
However, the truly subversive dimension was not, I would argue, that a new method was gaining ground in the public educational system; various ideas about this have come, disappeared and, in some cases, been reintroduced at least since Plato outlined his ideal in The Republic. The revolutionary aspect of these transmutations was rather how confidence in new methods over time contributed to what, with a somewhat incisive wording, could be defined as an inversion from content to form. Leaving the question of cause and effect aside, this should also be understood as a remarkable transformation of the ability and willingness of school, and thus also of the society at large, to articulate itself, where this act is to be thought of as one where reproduction and foundation are inseparable instances of one and the same act, the one not graspable without the other. This should, I maintain, be understood as a gradually growing collective unwillingness to explicitly articulate a direction of the current generation for the upcoming to, when their time is in and they become members of the public sphere, orient against. ${ }^{78}$ During the 1970 s, two aspects

cannot be school's task to keep youngsters from the seriousness, troubles and dangers of life. That would indeed to intentionally teach young people to bury their heads in the sand as soon as something unpleasant is imminent; if occasionally such a tendency can be traced also out in life, it is in any case not the task of school to promote the development of youngsters in this direction" (prov och examina äro, om de på ett naturligt sätt infoga sig i en väl planlagd och avvägd undervisning, i och för sig intet ont; vid den fortsatta utbildningen för olika levnadsbanor spela sådana prov ofta en avgörande roll, och situationer av liknande slag möta ofta ute i livet. Skolan skall låta barnet vara barn och låta ungdomen njuta av sin ungdom, men det kan icke vara skolans uppgift att för de ungas blickar liksom gömma undan livets allvar, mödor och faror. Det vore ju att planmässigt lära de unga att sticka huvudet $\mathrm{i}$ busken, så snart något obehagligt hotar; om understundom en sådan benägenhet kan spåras även ute i livet, så är det i varje fall icke skolans uppgift att främja de ungas utveckling i denna riktning)". SOU I944:20, p. 55.

${ }^{78}$ This can be compared to what Marie Demker and Ulf Bjereld called an ultramodern state, where the goals towards which the progress strives is rather "formulated in the process of change itself", see: Demker and Bjereld, 2005 , p. 2 of. Implicitly this happens, of course, in spite of how the elderly choose to introduce the younger to the existing world; like the 
emerge, which, as I shall argue further down, add to the fact that the "working-school method" was truly ground-breaking. The teaching paradigm that in parallel hereby took form, in virtue of its increasingly strong emphasis on forms of learning, adopted a structure that gradually more resembled the initially outlined coaching ideal; a shift away from the idea of student's development through the past, to the symbolically charged idea of individual's "inherent" potential, where the pupil's development is increasingly related to her own self-determination.

\section{Reproduction of Class Society}

A central change in the 1970 s was that the previously mentioned references to cultural heritage, cultivation of taste and suchlike, suggesting a continuing faith in the importance of introducing students to a particular content, disappeared in the $1970 \mathrm{~s} .{ }^{79}$ As a consequence, a symbolic counterweight to the idea of the relativity of knowledge thus disappeared. This suggests a shift towards a further relativization of the content taught, based on an even more solid belief in the importance of the teaching forms; shifts that, as Richardson has pointed out, should be understood in light of the overall aim of better preparing students for a life in democratic society. ${ }^{80}$

norm of free choice the idea of a more student-driven work is also a control strategy, a way to interpellate the recipients in question.

${ }^{79}$ Wedin, 20I $7 \mathrm{~b}$.

${ }^{80}$ Richardson, I983, p. 87. Ringarp also emphasizes how the SIA investigation was an expression of a focus shift towards a decentralization and an increased influence for students and parents, see: Ringarp, 20II, p. 48-49. Moreover, in order to better grasp the dynamics at play here, we have good reasons to distinguish between at least two different meanings of the adjective "democratic" in this sentence: on the one hand as political regime, and on the other hand as a culturally structuring ideal of modernity in the way of which Tocqueville defines it in the second volume of De la démocratie en Amérique. For an analysis of his relevance for understanding the educational policy changes in the Western world in general, and Sweden in particular, during the post war period, see: Wedin, 2017 a. 
The second aspect implies that the pupil's right as a democratic subject is now increasingly evident in the educational policy documents - both in reports and bills. It is for example a clearly present idea in the report over "The inner work of school" (SOU 1974: 53). ${ }^{81}$ The aspiration to create a more democratic and equal school that permeates this investigation should be read in light of the admonitions to dedicate a particular focus on the pupils with greatest problems in school. ${ }^{82}$

${ }^{81}$ SOU I 974:53, commonly known as SIA.

${ }^{82}$ The investigators write: "We have reasons to expect that a significant proportion of the pupils who end up in such a difficult school situation belong to the socially and culturally disadvantaged group. How these students can experience a sense of alienation in school has been described in an illustrative way by the English sociologist Bernstein (I970). As the school is unable to relate to the experiences of such pupils, they find that perceptions and values that were previously essential in life no longer are valid. A wedge is increasingly driven in between the student as a member of the family community and students as a member of the school community. While entering the school, he is therefore faced with the requirement to abandon his social identity. Even parents may feel inadequate when the education and experiences which pupils have accumulated at home is not beneficial in the school environment or even creates problems. This does not imply favourable conditions for the student's development and for the parents' involvement in the own child's education. In order to achieve the parent's active participation in the education process, Bernstein believes that they must be able to fully participate in their own ability to the extent that they are able to participate. This can, amongst other things, be achieved by retaining the students' experiences from home and the society outside school. "(Det finns anledning att räkna med att en betydande del av de elever som på detta sätt hamnar i en besvärligare skolsituation tillhör gruppen socialt och kulturellt missgynnade. Hur dessa elever kan uppleva en känsla av främlingskap i skolan har på ett belysande sätt beskrivits av den engelske sociologen Bernstein (1970). Genom att skolan inte förmår anknyta till sådana elevers erfarenhetsvärld, finner dessa att uppfattningar och värderingar som tidigare varit väsentliga $\mathrm{i}$ tillvaron inte längre äger giltighet. En kil drivs alltmer in mellan eleven som medlem i familjensamhället och elever som medlem i skolans gemenskap. Vid inträdet i skolan ställs han med andra ord inför kravet att överge sin sociala identitet. Även föräldrarna kan känna otillräcklighet när den fostran och 
In the directives we read that:

\begin{abstract}
Among the tasks of school is not only the transmission of knowledge but also, and equally important, to give pupils an opportunity to evolve into an independent citizen with personal involvement in the surrounding world. These opportunities must not be divested from a pupil because he has difficulties in school. School has, on the contrary, a particular responsibility for these pupils, as these years is a perhaps never-repeated opportunity to give them the opportunities for personal and social development that society is responsible to offer its citizens. ${ }^{83}$
\end{abstract}

By adapting teaching to the varying horizons of reality of different pupils, school could become better at receiving children from environments where other things than those which are traditionally ascribed the greatest importance in school have been encouraged. Reforms in this direction would make school more equal, as it was assumed to decrease the advantages with which children from better of backgrounds tend to come to school.

Shortly after the 1974 report was presented, the idea was repeated in a bill based on the report, "about the internal work of the school, etc." ${ }^{84}$ by the then Social Democratic government with

de erfarenheter eleven erhållit i hemmet inte är till gagn i skolmiljön eller rent av skapar problem. Detta innebär inga gynnsamma förutsättningar för elevens utveckling och för föräldrarnas engagemang i det egna barnets utbildning. För att få föräldrarna aktivt deltagande i utbildningsprocessen måste de enligt Bernstein mening ges möjlighet att med full tillit till den egna förmågan medverka i den omfattning de mäktar. Detta kan bl.a. ske genom att undervisningen bättre tillvaratar elevernas erfarenheter från hemmet och samhället utanför skolan.”). SOU I974:53, p. 304f.

83 "I skolans uppgifter ingår inte bara att förmedla kunskaper utan i lika hög grad ge eleven tillfälle att utvecklas till en självständig samhällsmedborgare med personligt engagemang i omvärlden. Dessa möjligheter får inte undandras någon elev, därför att han har svårigheter med skolarbetet. Skolan har tvärtom ett särskilt ansvar för dessa elever, då skoltiden är ett kanske aldrig återkommande tillfälle att ge dem de möjligheter till personlig och social utveckling, samhället är skyldigt att erbjuda sina medborgare." SOU I974:53, p. 64.

84 “[...] om skolans inre arbete m.m.”. 
Olof Palme as prime minister and Lena Hjelm-Wallén as Minister of Education:

\begin{abstract}
The point of departure for the proposals is that municipalities and school units in the municipalities should be given opportunities to adapt teaching according to individual pupils or groups of pupils' needs. [...] School should more than what is presently the case strive for a way of working that relates to pupil's reality. ${ }^{85}$
\end{abstract}

What implications did this have for teacher assignment? And how can this be understood in light of the institutional perspective that structures this paper? As emphasized above, the truly subversive aspect of the changes was the emphasis on forms at expense of content, as this meant such a radically new view on - and perception of - reproduction of society. To the three more specific forms of dissolution discerned on page 212-213, an additional, previously identifiable but now even more stressed is furthered; teachers should now, to a greater extent than earlier, approach the horizon of experiences of individual pupils. ${ }^{86}$

This was asked for in order to especially reach those who tend to have most difficulties at school. As is evident from the quote, this idea was further strengthened by stressing the fact that teachers is to offer students better opportunities for personal and social development. This, I maintain, is an expression of a change in which the private, in terms of pupil's personal experiences and interests, increasingly was expected to characterize the school as an institutional form. In combination with the calls from the 1970s and onwards, admonishing teachers to gradually include pupils in the ongoing democratic process, this bears witness of an expansion of what Arendt calls the social - and this in a fashion which seems

85 "Utgångspunkten för förslagen är att kommuner och skolenheterna i kommunen bör ges möjlighet att anpassa undervisningen efter enskilda elevers eller grupp av elevers behov [...] Skolan bör i högre än f.n. sträva efter ett arbetssätt som knyter an till elevernas verklighet." Bill I975/76:39, p. I.

${ }^{86}$ Which is in line with the changes that Joakim Landahl has described, see: Landahl, 2006, p. I $52 \mathrm{ff}$. 
indissoluble interlaced with the parallel dissolving of the lines of demarcation of demos.

This endeavor we also find on the first page of the goals and guidelines of the 1980 curriculum: "The school is obliged to give pupils increased responsibility and influence concurrently with their rising age and maturity." ${ }^{87}$ Intimately associated with this admonition was a change of emphasis of the concept of equality. ${ }^{88}$ This came, among others, to the fore in a clear criticism against school for its continued contribution to the reproduction of class society (which the calls for a greater consideration of pupils private experiences and interests should be understood as a retort to). ${ }^{89}$ Further manifestations of this were, I contend, the downgrading of the importance of content as well as the difference between practical and theoretical work in light of the desire to create a more equal school; a school where teachers assume an increasingly supportive role for the individual rather than working for the imparting/introduction - and hence also the articulation/explication - of the currently existing society as well as its emergence.

\section{A supportive and stimulating teacher role}

In the commission "Teachers in School for Development" (SOU 1978: 86), which underlay Teachers Training reform of 1988 and was strongly dominated by parliamentary representatives, the investigators took as their point of departure the assumption that school is developing towards:

\footnotetext{
87 "Skolan har skyldighet att ge eleverna ökat ansvar och medinflytande i takt med deras stigande ålder och mognad.” Lgr 80, p. I 5 .

${ }^{88}$ A change which also implies a shift of the implicit time horizon in educational policies, see: Wedin, 2017 b.

${ }^{89}$ Boman, 2002; Englund 2005, p. 268-272; Richardson 2010, p. I4, I38I40; Wahlström, 2002, p. 53; Börjesson, 20I6; Ringarp, 20II, p. 39 f., 46.
} 
- a broadened area of responsibility: the teacher's coresponsibility for student's overall personality development increases;

- a changing student role: teacher's role becomes more supportive and stimulating than directly knowledgemediating;

- a changing learning process: increased emphasis on those aspects of education that prepare the student to seek knowledge, to analyze, to consider and to make decisions, to influence and to change;

- a "more open" school: increased co-operation over classand subject boundaries as well as over student and staff boundaries in school; widened contact areas with the own community and with other countries. ${ }^{90}$

The characteristic trait, as to what regards our interest here, of the teacher assignment implicated in the investigation, is the downgrading of imparting knowledge. The teacher is depicted rather as a deliverer of the concealed energies that the child harbors. Based on the assumption of the active and creative child, a more supervising teacher role is advocated, where teachers, as stated in the above citation, supports and stimulates rather than transmit knowledge. The teachers' education should thus from now on be characterized, among other things, by a "significant influence for pupils over the content and form of education". ${ }^{91}$

Intimately intertwined with this further democratized teachers ideal is, I believe, the endeavor to bring different teacher categories closer to each other. Manifestations hereof are not only to be found in the teachers education reforms of 1988 and 2001, which both contributed to a nearing of teachers from different departments of school, but also in the bill on schools internal work already in the 1970s. On the first page of bill 1975/76:39, the Social Democratic Government representatives suggest that "primary school should more than what is currently the case apply working methods and forms of work that more closely connect to

\footnotetext{
${ }^{90}$ SOU I978:86, p. 24.

91 “[...] avsevärt inflytande för de studerande över utbildningens innehåll och utformning”. SOU I978:86, p. 24.
} 
preschool education". ${ }^{92}$ This call should be understood in light of the emphasis of the SIA investigation of a "soft school start", where commissioners stress that no tests of readiness for school attendance may occur. ${ }^{93}$ However, on an overall level, the admonitions should also be understood as an endeavor to create a more equal and inclusive school: a "truly equivalent education" as the phrase goes in the directives of the SIA-report. ${ }^{94}$

As mentioned above, the attempts to bring different teacher categories closer to each other were not new; already twenty years earlier, the Teacher Training Specialist Committee had argued against the distinction class teacher/subject teacher. Strongly contributing to this strive was the desire to not only change the forms of the parallel educational system, but to also dissolve the remaining implicit inner structures that continued to reproduce the now formally replaced educational system. ${ }^{95}$ To this ambition should now also be added the already discussed further downplaying since the 1970s. ${ }^{96}$ A consequence of the clearly expressed aim of having pupils learning how to learn rather than learning a particular content, was that critics of the distinction class/subject teacher were offered yet a further argument for their cause.

\footnotetext{
92 “[...] att grundskolan i högre grad än f.n. skall tillämpa arbetssätt och arbetsformer som mer knyter ant (sic) till förskolepedagogiken”. Bill I975/76:39, p. I.

93 Bill I975/76:39, p. I.

94 “[...] reellt likvärdig utbildning”. Protokoll 1970-05-27, Utbildningsdepartement, quoted in: Lindensjö and Lundgren, 20I4, p. 77.

${ }^{95}$ Which is in line with what historian Johanna Ringarp writes in her study on the teaching profession's municipalization. This reform should, she concludes her dissertation, be considered "[...] as another step towards balancing the working conditions, wages and status of the previously historically distinguished groups of teachers" ([...] som ytterligare ett steg mot att utjämna arbetsvillkoren, lönerna och statusen mellan de tidigare historiskt skilda lärargrupperna”), Ringarp, $20 \mathrm{I}$ I, p. I90.
}

${ }^{96}$ SOU I $978: 86$, p. $78 f$. 
In bill 1984/85:122, once again with Hjelm-Wallén as responsible Minister, (but now as Minister of Education), the government wanted - through the teachers training - to take further steps in this direction. In the introduction, they mention how the 1980 curriculum represented important steps towards dissolving the boundary between the role of class teachers and that of specialist subject teachers. The bill further mentions that, e.g., the introduction of thematic studies, new syllabuses, and an emphasis of the basic skills (reading, writing and counting) more distinctly shall permeate all three stages of school. ${ }^{97}$

In the wake of the 1980 curriculum, a merging of the orientation topics in two different blocks was also decided: social-studies as well as nature-oriented subjects. From now on, teaching should not only be based on "a subject matter", but rather "on questions and issues which the students are confronted with outside school". ${ }^{98}$ With the teacher education reform of 1988 , elementary school teachers training gained a more homogenous form as well: everyone who intended to work at elementary school would from now on go through a primary school education. This education was in turn divided into two directions: one aiming at form 1-6 and one at 3-9. For those who aimed at 3-9, the opportunity was offered to choose either nature-orientated subjects or social-studies oriented subjects. A special significance in the attempt to create a more student-centered school was attributed to didactics, which in the bill is described as the ability to make content "comprehensible for the student and put it into a context that the student understands and has experience of" [my italics]. ${ }^{99}$

\footnotetext{
${ }^{97}$ Bill I $984 / 85:$ I22, p. 4.

98 “[...] undervisningen på problem och frågeställningar såsom eleverna möter dem utanför skolan”. Bill I 984/8 5:I 22, 5 . An idea that, in the form of the theme work, would strongly reflect the teaching ideal in the I99os and beyond, see: Linderoth, 20I6, p. 2 If.

99 “[...] begripligt för eleven och sätts in i ett sammanhang som eleven förstår och har erfarenhet av". Bill I984/85:I22, p. I I.
} 
To which extent it is reasonable to read this attempt in light of the admonishment to have primary school methods approaching preschool education (see bill 1975/76: 39), is not inferable from the empirical material underlying this study. However, if we to the bills of 1975/76: 39 and 1984/85: 122 add the teacher education reform from 2001, where a common general educational program for all teachers - from pre-school teachers to high school teachers - a pattern seems to emerge. ${ }^{100}$ Common to the three bills from 1975, 1985 and 2000 is that they all point towards a homogenization of the teaching profession. ${ }^{101}$ Another common feature is that they all emphasize the importance of other "competencies" (conception borrowed from the teachers training bill of 2000) than the traditional transmission of a content. ${ }^{102}$

${ }^{100}$ Which is on the lines of how the Italian sociologist Piero Colla argues in his analysis of the impoverishment of the subject of history in educational politics throughout the Post-war period, see: Colla, 20I7, p. $87 \mathrm{I}$.

${ }^{101}$ Which is in line with the homogenization of the teaching body that education sociologist Emil Bertilsson shows in his dissertation: Bertilsson, 2OI4.

${ }^{102}$ Another reason for this was that in the 1988 reform, additional steps were taken, in line with the 1980 curriculum, towards clearer goal management, and gave municipalities a significantly greater influence over the decisions on how these goals could be achieved. As the education historian Agneta Linné has pointed out, this helped to change the teacher's assignment towards the ability of "local curriculum work, teamwork, follow-up and evaluation", see: http://www.lararnashistoria.se/sites/www.lararnashistoria.se/files/artikla r/Lärarutbildningen \% 20i\% 2ohistorisk\% 2obelysning o.pdf. Another aspect, highlighted by Stenlås, is the injunctions to have teachers working more closely around a pupil rather than with teachers from the same subject. As he points out, this also indicate that the centre of gravity shifted from time to in-depth studies within one subject, or deepening subject-related discussions with colleagues from the same subject, to more general discussions about pupils rather than subjects, see: Stenlås, 2009, p. 67. 
This is something that they share with today's remarkably severe economistic tone in educational policy issues. ${ }^{103}$ As Ylva Hasselberg writes, they both - the post-war's increasing focus on methods and pedagogy, as well as the later, strongly marketoriented educational policies - shift the "emphasis from the goals of the activity to the means that should be subordinated the goals: [economic] efficiency and pedagogy". ${ }^{104}$ Thus, following Hasselberg's argumentation, rather than petering out as the left wing impulses towards the end of the 1970s began to abate, these form- and technology oriented changes continued to structure educational policies all the way up to the last wave of reforms between 2008-2011.

\section{A democratic authority}

In line with what has been said, the Social Democratic Government behind the new teachers training bill En förnyad lärarutbildning (1999/2000:135), re-emphasize that it is becoming increasingly difficult to predict which knowledge that will be required in the future. Simultaneously, new concepts have now been added that seem to reflect certain shift of nuances:

The role of the teacher will therefore increasingly be attached to the ability to create personal meetings. Professional tasks become more personal than role-determined. Rather than taking over a role, or a tradition, each teacher must conquer and earn her/his own role -

103 Because it is an educational policy that strives to allow "entrepreneurship ... to penetrate the entire education system", see: "Strategi för entreprenörskap inom utbildningsområdet", Regeringskansliet (Näringsdepartementet \& Utbildningsdepartementet), 2009. For analysis of the entrepreneurship concept's growth and location in today's school, see: Ringarp, 20I3; Leffler, 2006; Wedin, 2015.

104 "[...] betoningen från målen med verksamheten till de medel som borde vara underordnade målen: [ekonomisk] effektivitet och pedagogik”. Hasselberg, 2009, p. 78. 
and hence her/his authority. Authority is something gained in a democratic process. ${ }^{105}$

Of particular interest here is that teachers should have the ability to create personal meetings: their tasks are now becoming increasingly personal. The invitation should be read in light of the equality-promoting admonishment that teachers should meet, and thus acknowledge, the individual student and her experiences. The idea of the deserved authority can be clearly related to the desire to create a more equal relationship between pupil and teacher, and hereby democratizing the educational system. Moreover, between the lines we can also glimpse a strong confidence in the performative dimension of knowledge. In line with the extenuation of the content, the contours take form of a teacher that in "personal meetings" with her students performatively creates knowledge. ${ }^{106} \mathrm{~A}$ further illustration of this is that teachers are asked to take greater responsibility for "orchestrating an activity implying that pupils and teachers develop mutual respect" ${ }^{107}$

The idea of staging leads thoughts to the ideas of knowledge and learning that Swedish professor in pedagogics Jonas Linderoth refers to as "constructivist-inspired teaching" in his recently published book Lärarens àterkomst. ${ }^{108}$ An expression of this, but as previously mentioned with roots far back in post-war educational policies, are the since the 1990s very influential ideas about socio-cultural learning. In policy documents, this is e.g. expressed in a discussion regarding the concept of knowledge in the report School for Bildung (SOU 1992:94), which was commissioned to provide a basis for the upcoming curriculum

${ }^{105}$ Bill I999/2000:I35, p. 8. The fact that some teachers have experienced that the teacher's authority in the classroom has decreased is, on the other hand, a perception that goes far back in time, see: Landahl, 2006, p. I 3 of.

106 Which can be compared to what Gert Biesta describes as a shift from education to learning: Biesta, 20I 2, p. 23.

107 “[...] iscensätta en verksamhet som innebär att elever och lärare utvecklar ömsesidig respekt”. Bill I999/2000:135, p. 8.

${ }^{108}$ Linderoth, 20I6. 
reform (which in turn formed part of the major educational reforms around 1990). ${ }^{109}$ In "knowledging," writes Ingrid Carlgren, the author behind the section on knowledge, there is no right or wrong: it is "work that is the goal". ${ }^{110}$ According to the socio-cultural learning, which she advocates, knowledge is described as:

\footnotetext{
[...] neither external nor inner, outside human, or any inner, inside the individual, but rather something that lies between the individual and the environment. An important part of this environment are other humans, the social context in which knowledge is communicated through language. ${ }^{111}$
}

Read against this background, the idea of staging not only appears more comprehensible, but does also render it more harmonious with the image of school that comes to the fore in bill 1999/2000: 135. As in previously analysed documents, it is emphasized that pupils should be involved in planning the work as well as, together

${ }^{109}$ Skola för bildning (1992:94). The Swedish theorist who is primarily associated with this perspective is Roger Säljö, which Ingrid Carlgren also refers to in her reasoning about the knowledge concept in the investigation. The ideas that the socio-cultural tradition rests on hark back to the Russian psychologist Lev Vygotsky (I 896-I934).

110 "kunskapandet [...] arbetet som är målet”. SOU I992:94, p. 67. Compare with Linderoth's reasoning regarding the constructivist epistemological theory of knowledge in: Linderoth, 2016, p. $38 \mathrm{ff}$.

111 "I ett sociokulturellt perspektiv är kunskaper inte något som individen har i form av färdigförpackade enheter som är lagrade i ett förråd. I varje fall är detta ingen lyckad bild. All den information som finns lagrad i böcker, och som individen kan ha tagit till sig, är exempelvis inte kunskap i sig.”, SOU I992:94, p. 73. Compare also, for example Roger Säljö’s description of an earlier textbook for the teacher program: "In a sociocultural perspective, knowledge is not something that the individual has in form of pre-packaged devices that are stored in a storehouse. In any case, this is not a good picture. For example, all the information stored in books, which the individual may have acquired, is not knowledge in itself.”, see: Säljö, 2000, p. I25. 
with teachers, to "determine how the goals are to be achieved". ${ }^{112}$ The teacher's task is thus, with new information technology, to primarily supervise pupils as well as to provide them with "conditions for evaluating, critically reviewing and process gained information to useful knowledge". ${ }^{113}$ In addition to the changes around 1990, the government emphasizes that one of the central motives behind the reform is that it should be seen as a rejoinder to the criticism that education had not given teacher students "the opportunity to develop the skills related to social and pupil-caring tasks of the teacher profession". ${ }^{114}$

The imperative that the teacher's task should be more personal rather than role-determined is, I think, symptomatic. It clearly narrows down the changing conception of the teacher that I have tried to discern here, and by extension school as an institutional form in its entirety, where the teacher's way of being, her character, is attributed an increasingly emphasized importance. In relation to the above outlined backdrop, this shift of emphasis should not be considered a deviation; with the downplaying of transmission of knowledge and clear requests that teachers rather should serve as a support for pupils to learn how to learn as well as parting from the personal experiences of pupils, the emphasis of the personal seems congenial. A yet further expression of this shift from school as a mediating institution, aiming at introducing emerging generations to the political sphere, was the catalog of individual-based values introduced in the new curricula of 1994, Lpo 94 and Lpf 1994 (for mandatory school and high school

112 “[...] avgöra hur verksamhetsmålen ska nås”. Bill I999/2000:I35, p. IO.

113 “[...] förutsättningar att utvärdera, kritiskt granska och bearbeta inhämtad information till användbar kunskap”. Bill I999/2000:I35, p. 9.

114 “[...] möjlighet att utveckla de kompetenser som hänger samman med läraryrkets sociala och elevvårdande uppgifter". In addition, it could not in a sufficiently big extent place the school in a broader context ("i ett större sammanhang"). Bill I999/2000:I35, p. IO. The competences in question are: cognitive, communicative, cultural, creative, critical, social and didactic skills. 
respectively). In virtue of being articulated without any substantively anchored backdrop that could give them direction, they appear primarily - in light of the focus of this paper - as a symptom of a decreasingly mediating institution, progressively more based on an abstract, atomistic idea of the individual. ${ }^{115}$ As the French philosopher Marcel Gauchet wrote already in 1980 regarding the reappearance of human rights in political debates:

It has formulated a demand, it has revealed a powerlessness. Of imagination, we are strangely deprived $[\ldots]^{116}$

\section{Conclusion}

From having been expected to pass on a selection of previous generations' knowledge to the new, the teacher's ideal throughout the post-war period shifted towards being a stimulating support for pupils, which in turn were expected to increasingly fill out the content themselves based on their preferences. ${ }^{117}$ Since today's content may at any rate be dated tomorrow, the supporting form becomes the primary teachers task. That this has contributed to a weakening of the teaching profession has been mentioned earlier. ${ }^{118}$ What I have tried to draw attention to here is (i) how we can track several of the long-term changes behind this shift back to the foundational ideas behind the comprehensive school, as well

${ }^{115}$ What is a change that has been discussed from different starting points and along different lines, among other things, by: Villey, 20I4; Milbank, 20I 2; Gauchet, 20I7; MacIntyre, 2016.

116 "Il a formulé une exigence, il a révélé une impuissance. D’imagination, nous sommes étrangements privés [...], Gauchet, 2002, p. I3.

${ }^{117}$ In a recently published (2015) sociological study of how an elite is reproduced in Djursholm, Swedish economist Mikael Holmqvist describes a similar development and argues that it contributes to replacing a meritocracy with what he calls a consecration, see: Holmqvist, 20I 5. Regarding the Bourdieu-inspired idea of consecration, see also Sandgren's study regarding the growth of boarding schools in Sweden (and in the rest of the world), Sandgren, 20I 5.

${ }^{118}$ Hasselberg, 2009; Stenlås, 2009; Stenlås, 201 I. 
as (ii) some hitherto insufficiently examined political-theoretical problems that these shifts have actualized.

In the preceding parallel educational system, it was clear how different pupils (generally from different classes of society), were prepared for different occupations (which tended to be within the same social stratum as that of the parents). When the comprehensive school replaced the parallel educational system, this was something that reformers hoped to do away with. However, as critics emphasized already in the 1970s, it didn't take long before critique amassed in this regard against the new comprehensive school as well. ${ }^{119}$ One crucial policy retort to this criticism was to change the forms of school's internal work. ${ }^{120}$ Hereby, an intensification was initiated of the widely shared conviction that school needs to be further democratized. The desire to create a more equal school thus goes hand in hand with the explicit endeavors towards a democratization. A consequence of this was that the boundary between pupils and teachers became increasingly diffuse. This is the first border-dissolving tendency that I disengage. A second change in the same vein was the desire to dissolve differences between what was originally class and subject teachers. The third border-annulling impulse that I highlight was the criticism of the dichotomy practical-theoretical work. These shifts should, I maintain, be understood as materializations of a changed notion of school as an institution, which increasingly was becoming regarded as part of the (democratic) public sphere. ${ }^{121}$

\footnotetext{
119 Boman, 2002; Englund, 2005, p. 268-272; Richardson, 2010, p. I4, I38-I40; Wahlström, 2002, p. 53; Börjesson, 20I6; Ringarp 20II, p. $39 f ., 46$.

${ }^{120}$ Englund, 2005, p. $2 \mathrm{I} 3$.

${ }^{121}$ The contradictory, inner equality dynamics that I highlight here may and should - be supplemented with studies which for example examine how the changes can be related to the ever-present economic framework; as Linderoth points out, it is for example also more cost-effective to allow students to work more independently, Linderoth, 20I6, p. 95. Due to the 
Another change is the from the 1970s and onwards stronger emphasis on teachers to further approach the shifting experiences with which pupils come to school; a request that goes hand in hand with the overarching aim to have school in general approaching pupil's horizons of experience. In so arguing, the reformers also in parallel brought about a furthering of the private sphere within this peculiar space "in-between"; as such, it was an over-time drawn out shift that we have good reasons to consider an expansion of what we with inspiration from Arendt could call the social. It is a manifestation of that which the Dutch sociologist Anton C. Zijderveld describes as an increasing anti-institutional modus, where common institutions are increasingly regarded as limitations of each individual's subjective identity. ${ }^{122}$

A further expression of this institutional dilution, are the transmutations that the teacher role has undergone, in particular as a consequence of the strive to counteract that the parallel school structures survived within the comprehensive school (which in itself should be understood as an expression of the impulse to enhance equality in the educational system). ${ }^{123}$ By downplaying the content-oriented, imparting aspect of education, school's practices approached the surrounding community, thus undermining it as a specific for the public preparing institution, and the teachers position within it. It is in this light, by virtue of

article-format of this text, with the considerations of space that this entails, such external causes have here been left aside.

122 Zijderveld, 2000, p. I3. The author here differs between normative subjektivism (the idea of self-creating and independent self) and the descriptive assertion that the individual has a central position in modern society (such as the bearer of rights, etc.). Zijderveld makes no secret that he is inspired by Émile Durkheim, see for example: Durkheim, 20I4, p. I-39.

${ }^{123}$ Like the recently named tendencies, these can also be related to the desire to create a more democratic and equal school. As stated above, however, this must also be understood in the light of the teacher shortage that followed in the wake of the explosive development of the educational system. 
representing the primary common institution, that I maintain that the late modern teacher ideal should be regarded as a character. ${ }^{124}$

Out of these shifts emerges what I would like to call the paradox of democratic equality. It consists in the fact, that the intensified attempts to create a school inspired by a public-oriented logic, in relevant respects seem to have helped paving the way for the clearly private-oriented logic that has characterized the development since the 1990s. As stated above, post-war educational policies were characterized by an effort to create a more democratic school: first through the comprehensive school, and then on in reforming the inner work. ${ }^{125}$ However, a consequence of this impulse was that the common fabric in which the pupil was expected to be integrated became more fragile as the importance of articulating/reproducing a common backdrop - in the name of democratic equality - was reduced. ${ }^{126}$ The catalog of individual-addressing values introduced in the 1994 curriculum is in this regard telling.

As a consequence of the pursuit of creating a more democratic school, various measures have been taken that have weakened school's special position as an institution whose primordial aim it is to prepare pupils for a life in the common sphere. The

${ }^{124}$ Regarding educational politics, see: Englund, 2005; Börjesson, $20 \mathrm{I} 6$. For studies in which the more comprehensive social changes are in focus: Boréus, I994; Antman et al., I993; Österberg et al., 2014.

${ }^{125}$ However, the basic structure of the problem has been extensively discussed for over 200 years. As the French philosopher Frédéric Brahami writes: "[...] society is in a strict sense democratic tot he extent that it falls upon the individual to judge it; nevertheless, if each individual expresses its personal opinion, it appears deemed to crumble away.", Brahami, 2016, p. 222.

${ }^{126}$ As I show above and others have shown before me, this does not mean that, for example, labour market adaptations have also - and perhaps even substantially - contributed to the changes depicted here. As already mentioned, in note 29 , the question of how different spheres of society relate to each other falls outside the scope of this paper. 
increasingly radical attempts of creating a more democratic and equal school have thus fomented an increased adaptation to the individual. In parallel, it has contributed to a furthering of the social in a way that has undermined school as a public project, paradoxically thus indirectly paving the way for the explicit privatization that occurred in the 1990s. Against this backdrop does, in order to mention the most conspicuous example of this, the introduction of a voucher system, which explicitly appeals to the private interest, no longer appears as such a sharp rupture. ${ }^{127}$ It seems rather as an - in terms of the tension between private and public - shift of nuances of an impulse that stretches all the way back to the discussions about the introduction of the comprehensive school. In this way, the here presented results also nuance the many studies emphasizing how the reforms around 1990 indicate a rupture with the previously pursued politics.

\section{References}

Albäck Öberg, Shirin, Thomas Bull, Ylva Hasselberg, and Niklas Stenlås. "Professions under siege". Statsvetenskaplig tidskrift 188.1 (2016): 93-126.

Althusser, Louis. 'Idéologie et appareils idéologiques d'État', Pensée nr. 151.3 (1970): 67-125.

Andersson, Jenny, and Kjell Östberg. Nordstedts Sveriges historia 1965-2012. Stockholm: Nordstedts, 2013.

Antman, Peter, Göran Greider, and Tomas Lappalainen, eds. Systemskifte: fyra folkhemsdebatter. Stockholm Carlsson, 1993.

Arendt, Hannah. Between Past and Future. New York: Penguin Books, 2006.

Arendt, Hannah. Människans villkor. Göteborg: Daidalos, 1997.

Arendt, Hannah. Responsibility and judgement, New York, Schocken Books, 2005.

Arendt, Hannah. "Thinking and Moral Considerations: A Lecture”. Social Research 38.3 (1971): 417-446.

${ }^{127}$ Compare with, for example, Englund, I994. 
Baggesen Klitgaard, Michael. "Do Welfare State Regimes Determine Public Sector Reforms? Choice Reforms in American, Swedish and German Schools'. Scandinavian Political Studies 30.4 (2007): 444-468.

Bergdahl, Lovisa, and Elisabeth Langmann. "'Where are You?' Giving Voice to the Teacher by Reclaiming the Private/Public Distinction". Journal of Philosophy of Education, 51.2 (2017): 461-475.

Bell, Daniel. The Cultural Contradictions of Capitalism. London: Heinemann, 1976.

Bertilsson, Emil. Skollärare: rekrytering till utbildning och yrke 1977-2009. Uppsala: ILU, Uppsala universitet, 2014.

Biesta, Gert. Bortom lärandet. Lund: Studentlitteratur, 2012.

Bjereld, Ulf \& Demker, Marie. I vattumannens tid? Stockholm: Hjalmarsson \& Högberg bokförlag, 2005.

Boman, Ylva. Utbildningspolitik $i$ det andra moderna: om skolans normativa villkor. Örebro: Örebro universitet, 2002.

Boréus, Kristina. Högervåg: nyliberalismen och kampen om språket 1969-1989. Stockholm: Tiden, 1994.

Brahami, Frédéric. La Raison du peuple. Paris: Les Belles Lettres, 2016.

Broady, Donald, Mikael Börjesson, and Emil Bertilsson. "Temaintroduktion: Lärarutbildningens hierarkier". Praktiske Grunde, 4 (2009): 7-18.

Bunar, Nihad. "Choosing for quality or inequality: current perspectives on the implementation of school choice policy in Sweden', Journal of Education Policy 25, no. 1 (2010): 1-18.

Börjesson, Mattias. Från likvärdighet till marknad: en studie av offentligt och privat inflytande över skolans styrning $i$ svensk utbildningspolitik 1969-1999. Örebro: Örebro universitet, 2016.

Castoriadis, Cornelis. Le monde morcelé: les carrefours du labyrinthe 3. Paris: Editions de Seuil, 1990.

Dewey, John. Democracy and Education. New York: The MacMillan Group, 1916.

Durkheim, Émile. Sociologie et philosophie. Paris: PUF, 2014. 
Ecclestone, Kathryn. "Resisting images of the 'diminished self': The implications of emotional wellbeing and emotional engagement in education policy". Journal of Education Policy, 22.4 (2007): 455-470.

Ecclestone, Kathryn, and Dennis Hayes. The dangerous rise of therapeutic education. London: Routledge 2009.

Englund, Tomas. 'Education as a citizenship right - a concept in transition: Sweden related to other Western democracies and political philosophies', Journal of Curriculum Studies 26.4 (1994): 383-399.

Englund, Tomas. Läroplanens och skolkunskapens politiska dimension. Göteborg: Daidalos, 2005.

Englund, Tomas. Utbildning som "public good" eller "private good": svensk skola $i$ omvandling? Uppsala: Educational Institution, 1993.

Erlander, Tage. 1940-1949. Stockholm: Tidens förlag, 1973.

Fraser, Nancy. "Can society be commodities all the way down? Post-Polanyian reflections on capitalist crisis". Economy and Society 43.4 (2014): 541-558.

Furedi, Frank. Therapy culture: Cultivating vulnerability in an uncertain age. London: Routledge 2004.

Furedi, Frank. Wasted: Why education isn't educating. London: Continuum 2009.

Gauchet, Marcel. l'Avènement de la démocratie IV: Le nouveau monde. Paris: Gallimard, 2017.

Gauchet, Marcel. La démocratie contre elle-même. Paris: Gallimard, 2002.

Giota, Joanna. Individualiserad undervisning $i$ skolan: en forskningsöversikt. Vetenskapsrådets rapportserie 3: 2013. Stockholm: Vetenskapsrådet, 2013.

Gustavsson, Jan-Erik, Sverker Sörlin, and Jonas Vlachos. Policyidéer för svensk skola. SNS Förlag: Stockholm, 2016.

Hasselberg, Ylva. Vem vill leva i kunskapssambället? Essäer om universitetet och samtiden. Hedemora: Gidlunds, 2009.

Holmqvist, Mikael. Djursholm. Sveriges ledarsambälle. Stockholm: Atlantis, 2015.

Illouz, Eva. Cold Intimacies: The Making of Emotional Capitalism. Cambridge: Polity, 2007. 
Irisdotter Aldenmyr, Sara. "Moral aspects of therapeutic education: a case study of life competence education in Swedish education". Journal of Moral Education 41.1 (2012): 23-37.

Ivarsson, Anders, Ylva Waldemarsson, and Kjell Östberg, eds. Det långa 1990-talet: när Sverige förändrades. Umeå: Boréa, 2014.

Jameson, Fredric. Postmodernism, or, The Cultural Logic of Late Capitalism. London/New York: Verso, 1992.

Karlsohn, Thomas. "Vad ska en svensk kunna? Om emotioner, kunskaper och institutioner". Vad ska en svensk kunna? Eds. Michael Gustavsson, Tove Österman \& Elinor Hållén, Göteborg: Daidalos, 2016.

Landahl, Joakim. Auktoritet och ansvar: lärares fostrans- och omsorgsarbete i historisk belysning. Stockholm:

Arbetslivsinstitutet, 2006.

Landahl, Joakim. "Skolämnen och moralisk fostran: En komparativ studie av samhällskunskap och livskunskap", Nordic Journal of Educational History 2.2 (2015): 27-47.

Lasch, Christopher. The Culture of Narcissism, Norton: New York 1979.

Leffler, Eva. Företagsamma elever: Diskurser kring entreprenörskap och företagsambet $i$ skolan. Umeå: Umeå universitet, 2006.

Lindensjö, Bo, and Ulf P. Lundgren. Utbildningsreformer och politisk styrning. Stockholm: Liber, 2014.

Linderoth, Jonas. Lärarens återkomst: från förvirring till upprättelse. Stockholm: Natur \& kultur, 2016.

Lundahl, Lisbeth. "Decentralisation, deregulation, quasi-markets - and then what?'. Journal of Education Policy 17.6 (2002): 687-697.

MacIntyre, Alasdair. After Virtue: a Study in Moral Theory. London/New York: Bloomsbury, 2016.

Marklund, Sixten. Vår skola: Historik, reformverksambet, dagens utbildningssystem, utvecklingstendenser. Stockholm: Bonniers, 1974.

Milbank, John. 'Against Human Rights: Liberty in the Western Tradition', Oxford Journal of Law and Religion, 1.1 (2012): 203-234. 
Rieff, Philip. The Triumph of the Therapeutic: Uses of Faith After Freud, Harper \& Row: New York, 1966.

Richardson, Gunnar. Drömmen om en ny skola. Stockholm: Liber/Allmänna förlaget, 1983.

Richardson, Gunnar. Svensk utbildningshistoria: skola och sambälle förr och nu. Lund: Studentlitteratur, 2010.

Ringarp, Johanna. Professionens problematik: lärarkärens kommunalisering och välfärdsstatens förvandling. Stockholm: Makadam, 2011.

Ringarp, Johanna. "From Bildung to Entrepreneurship: Trends in Education Policy in Sweden". Policy Futures in Education 11.4 (2013): 456-464.

Sandgren, Petter. Internatskolorna: att fostra en elit. Stockholm: Atlantis, 2015.

Semola, Hannu. "Construction of the Finnish teacher in the national steering documents of the 1990s. Tasks and qualifications." Reform policy and teacher professionalism in different Nordic countries. Eds. Klette, Kirsti; Carlgren, Ingrid; Rasmussen, J; Simula, Hannu, and M. Sundqvist. Oslo: University of Oslo, 2000.

Smeyers, Paul; Smith, Richard, and Paul Standish. The therapy of education: Philosophy, happiness and personal growth. Basingstoke: Palgrave Macmillan, 2010.

Stenlås, Niklas. "En kår i kläm - läraryrket mellan professionella ideal och statliga reformideologier". Rapport till expertgruppen för studier i offentlig ekonomi 2009:6.

Stenlås, Niklas. "Läraryrket mellan autonomi och statliga reformideologier". Arbetsmarknad \& Arbetsliv, 17.4 (2011): 11-27.

Säljö, Roger. Lärande i praktiken. Stockholm: Prisma, 2000.

Vinterek, Monika. Individualisering $i$ ett skolsammanhang. Forskning i fokus nr. 31, Myndigheten för skolutveckling. Liber: Kalmar, 2006.

Wahlström, Ninni. Om det förändrade ansvaret för skolan. Örebro: Örebro universitet, 2002.

Wedin, Tomas. "In Praise of the Present: The Pupil in Centre in Swedish Educational Politics". History of Education (2017b): 768-787. 
Wedin, Tomas. "Tocqueville, Educational Policies and Individualisation: on the democratisation of post-war educational policies in Sweden". Studies in Philosophy and Education, submitted, 2017a.

Wedin, Tomas. "The Rise of the Knowledge School and its Relation to the Resurrection of Bildung". Nordic Journal of Educational History 2.2 (2015): 49-67.

Villey, Michel. Le Droit et les Droits de L'Homme, Paris: PUF, 2014.

Ziehe, Thomas. Kulturanalyser. Ungdom, utbildning, modernitet. Stockholm/Stehag: Symposium, 1993.

Zijderveld, Anton. The Institutional Imperative. Amsterdam: Amsterdam University Press, 2000.

Östling, Johan. Nazismens sensmoral. Stockholm: Atlantis, 2008.

\section{Offentligt tryck}

Skolan i samhällets tjänst: frågeställningar och problemläge. SOU 1944:20.

1946-års skolkommissions betänkande med förslag till riktlinjer för det svenska skolväsendets utveckling. SOU 1948:27.

Den första lärarhögskolan. SOU 1952:33.

Lärarutbildningen: 1960-års lärarutbildningssakkunniga IV:1. SOU 1965:29.

Utredningen om skolans inre arbete. SOU 1974:53.

Lärare i skola för utveckling. SOU 1978:86.

Skola för bildning. SOU 1992:94.

Staten får inte abdikera - om kummunalisering. SOU 2014:15.

Bill 1950:70.

Bill 1975/76:39.

Bill 1984/85.

"Strategi för entreprenörskap inom utbildningsområdet",

Regeringskansliet Näringsdepartementet \&

Utbildningsdepartementet, 2009.

Mål och riktlinjer för grundskolan: Läroplan för grundskolan 1980 (Lgr 80). 
Tomas Wedin is a $\mathrm{PhD}$ Candidate at the Department of Literature, History of Ideas, and Religion, University of Gothenburg. Recent publications include: 'In Praise of the Present', History of Education 46.6 (2017): 768-787.

The terms and conditions of use are related to Creative Commons Attribution Licence (CC-BY) @) (1) 


\section{Appendix III: Tocqueville, Educational Politics and Individualisation: On the Democratisation of Post-War Educational Policies in Sweden}





\title{
Tocqueville, Equality and Individualisation
}

\author{
On the Democratisation of Pre-University \\ Education in Postwar Sweden
}

TOMAS WEDIN*

When the reforms of the Swedish educational system were launched soon after the Second World War, an essential ambition was to create a more democratic and equal school. ${ }^{1}$ Besides the economic reasons of making it more efficient, a key motive behind the reforms was to create more equal opportunities for all pupils, independently of their social background. The period was, according to the dominant historiography, later interrupted by a number of policy changes around the 1990s - most notably the introduction of a voucher system, the delegation of responsibility from state to municipalities, as well as the facilitation of starting private schools - described as expressions of a "system change". ${ }^{2}$ Considered as such, it is often related to a neoliberalisation of Swedish politics more generally. ${ }^{3}$

For all the merits of this narrative of a rupture, it obscures a dimension of the policy changes that I maintain have been crucial. Drawing on previous analyses of educational policies, I will reactivate Tocqueville's analysis of the role of equality in modern society and argue that his reflections on the burgeoning modern society enable new and fertile ways of understanding the dynamics of this period of "continuous educational reforms". ${ }^{4}$ The purpose of the study is thus to discuss how and why some of the central strands in his reflections on democratic society can elucidate certain aspects of the transformations of the Swedish postwar educational landscape that have hitherto been overlooked.

The paper will proceed as follows: in the first section, the background against which Tocqueville wrote is briefly presented, as well as why and how his analysis remains relevant for understanding postwar society. In

* Doktorand, Institutionen för litteraturvetenskap, idéhistoria och religion, Göteborgs universitet, tomas.wedin@gu.se 
the second section, I give an outline of the relevant themes. In the third section, I present the relevant Tocquevillian themes via four analytical categories: (i) democratic epistemology; (ii) opinion replacing authority: the transhistorical premise; (iii) temporal provincialism; and (iv) a shift from social to natural bonds. In the fourth section, I open with a brief account of the dominant interpretations of the policy changes around 1990, whereupon the categories are activated. In the concluding section, I summarise and discuss the further implications of my findings.

I argue that a specific form of imagined [imaginaire] equality has been a crucial ideological component of the reforms, propelling a dismantling of different forms of substantial ideals in the form of qualitative distinctions, most notably manifested by disparaging the transmission of a given content and in nourishing a new role for teachers. By qualitative differences, I refer to structuring ideals that transcend the individualist values of self-determination and positive rights. ${ }^{5}$ In virtue of representing something other vis-à-vis the individual, I shall refer to this shift as the withering of alterity as a structuring ideal in educational policies. To this end, I will show that in reactivating particular Tocquevillian themes it is possible to discern and delineate these major changes in the postwar education system.

Concomitant with this structuring ideal of equality has been - and remains - a predominantly negative ideal of liberty, whereby liberty is conceived of as the exercise of the unimpeded individual will, both of which are intertwined with a predominant focus on the present (at the expense of both past and future as structuring time horizons). This postwar educational impulse has indirectly facilitated a privatisation of the educational sphere. ${ }^{6}$ Via the Tocquevillian categories outlined, I will argue that central tenets of the postwar equality-promoting impulse prepared the ground for the subsequent (from 2006 onwards) and explicit admonition to address the pupil as an "entrepreneur of himself". ${ }^{7}$

\section{The relevance of Tocqueville (i)}

From our horizon, with the postwar political landscape and the reforms around 1990 in focus, the questions with which Tocqueville struggled are pertinent for at least two reasons. First of all, like most of his contemporaries, Tocqueville was anxious about what the French philosopher Frédéric Brahami has described as a "shared sentiment of an offense made against time of the Revolution". ${ }^{8}$ The revolution was experienced not only as an institutional and moral revolution, but also as an action where men attempted to become "constructers of time" rather than being in time. ${ }^{9} \mathrm{~A}$ crucial dimension of Tocqueville's critique of the process of democratisation 
was that this would tend to dis-embed individuals and to foment an increasingly abstract idea of the individual, denying the society and traditions that preceded her. ${ }^{10}$ During the postwar period, this dimension has, I maintain, become alarmingly topical with the attempt to democratise the educational system.

The second reason goes back to the political gaze orienting his reflections. Just as the anthropologist, moving from one cultural sphere to another, can see things that pass unnoticed by those immersed in it, so we can unveil and/or further our understanding of our society by dint of approaching it via a time-bound outsider struggling with the phenomena as they emerged. ${ }^{11}$ In virtue of operating "in-between two worlds", rooted in the old world but restlessly curious about the new one emerging in front of him, Tocqueville was well placed to do this. ${ }^{12}$ It is against this backdrop that I hold that Tocqueville's reflections on the modern form of equality, and its relationship to individualism, are of relevance for understanding our late modern condition.

\section{The process of democratisation: some preliminary remarks (ii)}

It was after having been sent to USA on behalf of the French government to write a report on their penitentiary system that Tocqueville undertook the work that would lead to De la démocratie en Amérique, undoubtedly his most famous work. Although discussing his experiences in the USA, the purpose was not primarily to provide an image of the USA as a case study in itself; Tocqueville's ambition was to approach North America in order to get an idea of what to expect - and fear - from the process of democratisation also in Europe. As he writes in the introduction to book one:

[T]here I have looked for an image of democracy itself, of its penchants, of its character, its prejudices, its passions; I wanted to get to know it, if only at least to understand what we can hope for and fear from it. ${ }^{13}$

Two essential concepts, defined in slightly unorthodox ways, in his thought are democracy and equality. In contrast to the classical tradition, democracy does not here refer to a regime in the Aristotelian sense. ${ }^{14}$ Instead, democracy is defined as a social state of society, a form of structuring pattern. ${ }^{15}$ Drawing on Montesquieu's idea that each regime has its principle, Tocqueville argues that the specificity of the democratic age is that equality is the superior principle, or passion, inspiring people to act. ${ }^{16}$

Equality, or equality of conditions, is not defined in any consistent way in De la Démocratie en Amérique. On the one hand, in the opening pages of book one Tocqueville asks rhetorically: 
[...] after having destroyed feudality and vanquished the kings, will democracy retreat in the face of the bourgeoisie and the rich? Will it stop now that it has become so strong and the adversaries so weak? ${ }^{17}$

Then, in book two, published five years later (1840), he indicates that there are clear differences between rich and poor people in the USA, and that the emerging industrial class could develop into a new elite. ${ }^{18}$ And, he continues, should some people have the "misfortune of arriving" at a condition "of perfect equality", there would still be "inequality of intelligences, which, coming directly from God, will always elude the laws". ${ }^{19}$ Moreover, although indicating an awareness, he did not explicitly take on what Raymond Aron a century later would refer to as the dialectics of equality, i.e. the complex interplay in modern society between the desideratum of equality and the hierarchical order that a high level of production seems to imply. ${ }^{20}$ As such, how to understand his idea of equality and its role in history remains a matter of debate. ${ }^{21}$

As an operative definition for the purpose of this article, I will draw on the French philosopher Marcel Gauchet, who - in "Tocqueville, l'Amérique et nous" - defines equality of conditions (in Tocqueville's thought) as a structure. In this light, equality is not

[...] discernible in itself, within each and every one of them [the individuals] taken by itself. It rests on the socially defined way in which they meet and situate one against the other - on the structure of a relation that determines them $[\ldots]^{22}$

Equality will thus, as Tocqueville himself puts it, be defined as a "sort of imagined [imaginaire] equality, in spite of the real inequality of their [the citizens'] conditions"; a structuring principle, inculcating among its members the idea that they are similar. ${ }^{23}$ As such, it must be distinguished both from "formal" equality (before the law, etc.) and distributive or "real" economic equality. Preceding hierarchical societies had been organised around an explicit, collective, normative structuring ideal, serving to integrate "society with reference to its values", and as such to something other than the individual. ${ }^{24}$ Another way to think of the structuring idea of the semblable is therefore to understand it as the evanescence of, in accordance with how I defined it above, alterity as a principle around which society is ordered. Due to the rise of the absolutist state in Europe, subjects were continuously suppressed under an ever-stronger state:

Under l'Ancien régime like in our times, there did not exist a city, borough, countryside, village, not even a small hamlet in France, hospital, fabric, convent or college, that could have an independent say in its specific affairs, 
and in the administration of its own possessions. Then as well as now, the administration thus held the French in tutelage, and if the insolence of the word had not yet been created, one had at least the thing..$^{25}$

The specific trait of democratic society is thus its successive elimination of qualitative hierarchical structures. ${ }^{26}$ As the order of similarity progressed, new fields were - and are - successively included; it is in this light that Tocqueville's thought, or so I maintain, becomes apposite for our understanding of the postwar educational changes and how they tie in with the reforms around 1990.

Indissolubly intertwined with this all-encompassing ideal of equality is, according to Tocqueville, each individual's enhanced focus on herself. In order to clarify the difference, he makes a distinction between egoism and individualism. Whereas the egoistic propensity to an exaggerated love of oneself was not unfamiliar to earlier societies, individualism is defined as the "reflected and calm sentiment that disposes each citizen to isolate" herself from her co-citizens. ${ }^{27}$ While analytically distinguishable, the latter will not leave the former untainted; soon, individualism will tend to undermine the political virtues, which depend for their survival on a mediating instance between the separate individuals. With time, it will therefore also hinder the development of other virtues, and thus, by extension, breed egoism as well. ${ }^{28}$ To the extent that these forces are not countered by appropriate means, they run the risk of also backfiring against the most fervent advocates of an unfettered individual:

When the conditions are equal, each person voluntarily isolates within herself and forgets the public world. If the legislators among democratic peoples do not make any effort to counterbalance this fatal tendency, or favour it with the intention to reroute the citizens from political passions and thus divert them from revolutions, it might be that they end up producing the evil that they wanted to avoid, and that one day the moment comes where the disordered passion of a few men, helped by the unintelligent egoism and pusillanimity of the majority, ends up constraining the political body to undergo strange vicissitudes. ${ }^{29}$

For Tocqueville, it is nevertheless crucial that it is the latter - i.e. individualism - that is deemed to be intrinsically intertwined with democratic society.

\section{Four dimensions of the process of democratisation (iii)}

Democratic epistemology (i). The first aspect to which I would like to draw attention is Tocqueville's reflections on the prevalent "philosophical method" of men in democratic society. Method must here not be understood 
as a specific reflexive way of orienting in the world; rather it should be understood as the implicit fashion in which individuals approach the world. The characteristic way in which people will tend to approach the world in democratic societies should, he continues, be seen in light of their strong belief in their own capacities; conversely, they will exhibit an equally limited trust in other persons. As pointed out, one of the linchpins of Tocqueville's sociological theory is how the non-hierarchical imagined equality in democratic society is concomitant with an impulse among its citizens to retreat into themselves. On the relation between the two dimensions, he writes that: ${ }^{30}$

[...] not seeing in any of them [the other citizens] the signs of any grandiosity or incontestable superiority, [they] are incessantly driven back to their own reason as the most visible and closest source of the truth. It is thus not only confidence as such that is destroyed, but the very taste for taking a man whomever at his word. ${ }^{31}$

Closely connected to this strong belief in one's own abilities is the democratic penchant for the concrete and practical, for non-abstract thinking. In order to get to the point, so to speak, democratic men will be particularly keen to get rid of anything that will keep them separated from the object at hand - theories included. This will tend to make them deeply hostile to abstract thoughts, considering them to be "useless and bothersome veils placed between them and the truth". ${ }^{32}$ Similar ideas come to the fore in Tocqueville's reflections on the sciences, which he believes will be strongly biased vis-à-vis "the tangible and real", and to be "inversely contemptuous towards traditions and forms". ${ }^{33}$

Along the same lines, he discerns two ways of approaching the sciences. One is practically oriented, structured by instrumentalism and mercantile considerations, whereas the other is disinterested, pursuing truth as an end itself. ${ }^{34}$ The preference that men in democratic society have for the former is, in Tocqueville's own words, explained by the fact that they are "greedy for material and present pleasures [...] always unhappy with the position that they occupy". ${ }^{35}$ Besides this explanation, which in evoking materialism as the explanans seems to be question begging, I would want to adduce another, more Tocquevillian, justification. ${ }^{36}$

For an individual approaching science from this "democratic" starting point, it will be easier to submit to a cognitive framework clearly related to an immediately experienced interest than to a theory demanding submission "merely" for the sake of understanding. It will be harder because it demands submission to a non-discernible and arguably non-existent concrete goal, but rather an abstract finality in the form of a backcloth to orient against, which in its essence implies a lack on the part of the person 
seeking it. ${ }^{37}$ In virtue of representing something beyond the confines of the individual and her immediate interests, and as such representing otherness, it is therefore much more unlikely to penetrate and compel individuals in democratic society.

Opinion replacing authority: the transhistorical premise (ii). In spite of the predilection for democratic epistemology, Tocqueville continues, no one can live a life entirely based on their own experiences. Anyone who actually tried to empirically find out for herself how to act in each and every situation would render her reason increasingly weaker, restraining her from plumbing the depths of any issue. ${ }^{38}$

In democratic societies, as in all other societies, people will, in consequence, inevitably also rely on preformed judgements. But rather than believing in what this or that concrete person professes - unwilling to be subject to any concrete equal - they will instead tend to let their actions be inspired by opinion, and this with a fervour analogous to the high esteem in which they hold their own belief. ${ }^{39}$ Faced with the sum of a large, abstract and undefined number of equals, the insignificance of the individual now becomes as overwhelming as her corresponding belief in her own forces. Hence, the very same impulse that triggered her not to take anything on trust from a concrete authority also, in accordance with the same logic, invites her to believe all the more strongly in the opinion. ${ }^{40}$ This leads Tocqueville to conclude that:

In equality, I can clearly see two different tendencies: one directs the mind of each man towards new thoughts, whereas the other one would happily reduce him to not think further. ${ }^{41}$

The individualism that democratic society renders possible must therefore be considered primarily as a challenge, a window of opportunity, rather than as an accomplished fact. In order to make this thought more concrete, we could say that the sceptical attitude towards authorities in democratic society must not be confused with all individuals' inevitable dependency on exterior sources of inspiration:

Individual independence can be more or less extended; it could never be without limits. Thus, the question is not whether there exists an intellectual authority in the ages of democracy, but simply where it resides and by what standard it is to be measured. ${ }^{42}$

Temporal provincialism (iii). A further consequence of the democratic epistemology is, Tocqueville notes, the temporal breaches that this will tend to trigger. Increasingly trusting in their own beliefs here and now, individuals 
in democratic society will be less interested in and prone to draw from what has been thought and done. ${ }^{43}$ Besides the aversion towards concrete authorities, we ought therefore also to add an enhanced temporal distance. ${ }^{44}$ The individualism nourished by democratic society is thus interdependent with what could be called a contraction of temporal horizons, diminishing both past and future to the advantage of the present:

\footnotetext{
In this way, democracy does not only make each man forget his forbears but hides his descendants from him and separates him from his contemporaries; it drives him incessantly back into himself and threatens to lock him up entirely in the solitude of his own heart. ${ }^{45}$
}

This drift towards an ever-greater provincialism of time can, furthermore, be related to how a given society is conceptualised. ${ }^{46}$ In conformity with the unwillingness to submit to concrete authorities, individuals in democratic societies will be equally reluctant to be fettered by the shackles of invented traditions. The narrowing time horizon and increased individualism therefore seem to be mutually reinforcing. Again, this does not imply that individuals will cease to interact with each other; rather it will trigger new forms of relating to others: from common beliefs and ideals, to bonds knitted via mutual interests. Finally, it should be emphasised that the envisioned contraction towards the present is on the level of the content of Tocqueville's reflections, not the structure of his thought more generally, which is firmly rooted in the emerging historicist vision of the world. ${ }^{47}$

From conventional to natural bonds (iv). Another aspect of democratic societies is what the author of l'Ancien régime et la révolution française refers to as the softening of mores: on a societal level in general and in the family in particular. Although the democratic energies dissolve convention-based social bonds, they strengthen others, in particular bonds between family members. While they promote a general softening of discipline, they will also tend to be infused with energies they previously did not have at their disposal. ${ }^{48}$ This could be described as a form of de-conventionalisation of upbringing, where previous norms are replaced by less rigid and more tender forms of educating children. This, concludes the author, is in line with a more encompassing shift taking place in democratic societies: "Democracy loosens the social bonds, but it tightens the natural bonds. It brings family members closer at the same time that it separates citizens"; and this, he adds, could be considered a summary not only of the actual chapter 'The influence of democracy over the family', but of a number of others as well. ${ }^{49}$ 
It thus follows that the categories operate on two different levels. Whereas (i) the democratic epistemology, (iii) the temporal provincialism, and (iv) the shift from conventional to natural bonds are historical categories, the second theme (ii) opinion replacing authority: the transhistorical premise, as indicated, is of another kind. As such, the latter will in the subsequent application of the categories be employed in a somewhat different fashion, serving as a form of underlying condition in contrast to the historical categories.

Tocqueville, individualism and the challenge of democratic education (iv)

Postwar educational policies in Sweden are often divided into two general periods. ${ }^{50}$ The first, dominated by the strong influence of the Social Democratic Party, aimed at promoting a more democratic and equal educational system. Clear manifestations can be seen in the Comprehensive School reform (enhetsskolan) in 1962 and the attempts to democratise the school's inner life. This period was then interrupted by a number of policy changes around the 1990 s described as expressions of a "system change". ${ }^{51}$

The reforms referred to are primarily the introduction of a voucher system as well as the delegation of responsibility from the state to the municipalities. As many studies have shown, these reforms spurred a development towards a more user- and market-oriented school system. ${ }^{52}$ A second important change during the 1990 s was the shift towards management by objectives, which in turn forms part of a more general reorientation under the influence of New Public Management in Swedish politics. ${ }^{53}$ During the same period, a discursive shift took place wherein education was successively replaced by learning as a key term in central policy documents. This is a shift that the educational philosopher Gert Biesta relates to the marketisation of the educational system. ${ }^{54}$ These changes notwithstanding, politically significant - and often overlooked - signs of continuity are also identifiable.

The paramount aim with the democratisation of the educational system during the postwar period was to replace the existing school system, which was based on two, strongly class-biased, pathways - "a class society in miniature" - with one school: the Comprehensive School. ${ }^{55}$ The ambition was to change not just the forms of education, but the inner life of schools as well; the "school of authority" would now, the commissioners argued, be replaced by the "school of activities" ${ }^{56}$ Deterred by the experiences in the totalitarian states and determined to further the democratisation of Swedish society, the 1946 School Commission declared that the coming 
educational reform should aim at not only reflecting the democratic society, but also creating a "democratisation of the school system" itself. ${ }^{57}$

As earlier research has shown, the decentralisation launched with the 1989 bill, transferring the lion's share of the responsibility for schools from the state to municipalities, was in significant respects the culmination of a trend that stretched back to the 1970 s. ${ }^{58}$ The critique vis-à-vis the centralist state was a crucial aspect of social criticism in 1968, which in important respects shaped political life in the 1970s. One of the suggested reforms was a decentralisation of decision-making in order to bring power closer to the citizens, thus furthering the process of democratisation - including the educational system..$^{59}$ But as we shall see, the decentralisation was not the only crucial strand of continuity between the postwar policy changes and the reforms around $1990 .{ }^{60}$

To Tocqueville, one of the characteristic traits of the emerging democratic society was what he referred to as de-conventionalisation of upbringing (iv), in which hitherto dominant practices were replaced by more flexible and tender forms of educating the child. During the postwar period, a number of reforms were realised that could - and should - be seen as manifestations of this. In order to avoid reproducing the previous parallel school system, where differences between teachers in various school forms were significant, measures were taken to diminish differences between various teacher categories. Policy documents reveal an ambition to diminish differences between teachers on various levels (varying from teaching pupils between 5-19 years). Therefore, wrote the commissioners of 1946, the "teacher's training should to a large degree be made common for all categories of teachers". ${ }^{61}$ Moreover, the suggested colleges for teacher training were expected to serve as an institutional materialisation of the democratic school; they should become a "breeding ground for progressive pedagogics". ${ }^{62}$ In relevant respects, this ambition culminated in the teacher training reform of 2001 , where teachers on all levels followed all teacher-specific courses together. ${ }^{63}$ In contrast to the previous structuring ideas, where the public educational system was thought of as an institution introducing pupils to a convention-based public world, further initiatives were now taken to adapt school to the pupils' experiences, thereby making it more home-like and natural (from the perspective of pupils that is).

Besides the ambition to make uniform different teacher categories, a further objective was to reduce teachers' authority and to increasingly delegate more and more decisions to pupils. The teachers were, moreover, exhorted to further include the experiences with which pupils came to school. ${ }^{64}$ As the commissioners put it in a report on the changing role of teachers in the emerging school, their role will "become more supporting 
and stimulating rather than directly transferring knowledge". ${ }^{65}$ Authority, write the Social Democratic government representatives in the teachers' training bill of $1999 / 2000$, is "something that one procures in a democratic process". ${ }^{66}$ Along the same lines are the summons to decrease the gap between different stages in school, to prioritise caring aspects in school, and the strong critique of grading. ${ }^{67}$

Tocqueville claims that natural bonds will tend to strengthen, whereas citizens concurrently will distance themselves from one another. In spite of the proclaimed efforts to further deepen the democratisation of the educational system, I would argue that the above-mentioned changes indicate an indirect sapping of belief in common institutions, which depend on convention-based ways of inter-individual coalescence. The tendency worked indirectly by undermining the role of teachers as transmitters, and as such the representatives of common institutions, vis-à-vis the pupils and their parents. ${ }^{68}$ Another way to present these changes is to describe them as a political shift undermining the artificially constructed idea of a political community in the name of democratic equality. In adapting school to the private experiences with which pupils arrive, the school as an arena in which pupils are prepared for life in the public sphere (incarnated by the authority of the teacher) was undermined. ${ }^{69}$

Returning to the initially defined definition of equality, this can be described as the ideal of the imagined equal serving to undermine the normative basis on which a shared political order could justify and impose itself. It is in this sense, I argue, that it is motivated to speak of a shift of emphasis from the artificially instituted public institutions, to the admonition of a more home-like and intimate approach among teachers and others employed in schools. ${ }^{70}$ To be sure, the ambition was not to intentionally "privatise" the educational system, but rather to make it a more familiar and welcoming place, particularly for those coming from non-academic homes. Thus, when New Public Management entered Swedish political life in the 1990s, the manifest economism in which it was immersed might have been a novelty, but the sapping of the school qua institution articulating/reproducing the public realm had been prepared well in advance. ${ }^{71}$ And as for the promoted role of the teacher during the 1990s, it was only further driven towards the democratic ideals sketched above. ${ }^{72}$

The second aspect that I would like to highlight is related to the increased ephemerality of the content declared in the policy documents, or the time-bound provincialisation (iii) that I argue took place during the period. ${ }^{73}$ In a world where, as it was claimed in a number of policy documents, the knowledge of today runs the risk of being outdated tomorrow, it is all the more important that pupils improve their learning techniques rather than simply internalise a given content. ${ }^{74}$ This shift towards learning 
how to learn is neatly captured in the introduction of knowledge as a verb, "to knowledge" (kunskapa), in policy documents in the 1990s. ${ }^{75}$ As the professor of pedagogics Ingrid Carlgren puts it in her contribution on the new concept of knowledge in the report of 1992, it is:

[...] neither something outward nor inward, outside of man, nor something inward, inside of the individual, but rather something that rests in-between the individual and the surroundings. An important part of these surroundings are other humans, the social context in which knowledge is communicated within language. ${ }^{76}$

This shift of emphasis, or so I maintain, further strengthens the expansion of the present at the expense of past (forbears) and future (descendants).$^{77}$ As the belief in the relevance of a particular content and the transmitting teacher diminished, so too did both past and future as balancing temporal horizons. The past was directly undermined by the questioning of a specific content, as the democratic teacher as an ideal implied a strong belief in the pupil's own reflective forces in the present. As it is formulated in the report concerning the teacher in the new democratic school, teachers should provide pupils with a framework for "self-realisation, beingtogether-experiences and shared solidary work in the present". ${ }^{78}$ It thus appears as if the downplaying of temporal continuity vis-à-vis the past successively spilled over and undercut teachers' legitimacy to exercise an influence on the child's long-term interest. This shift was reinforced by the pupils' proclaimed right to exercise a greater influence and the idea of inviting them to practice democracy in school. ${ }^{79}$

Nevertheless, it would be naïve to believe that any individual had the cognitive forces to get by without relying on preformed judgements. The sceptical attitude towards explicit authorities does not, as emphasised in the second theme (opinion replacing authority: the transhistorical premise), inhibit individuals from relying on exterior sources. As Tocqueville argues, opinion will replace the role of exterior, concrete authorities. Clearly, these reflections are not directly applicable in comprehending the changes in the educational system. Still, it is not difficult to imagine how peer pressure among pupils could roughly be compared to Tocqueville's opinion; as the formalised authorities withdraw, informal sources of influence expand. ${ }^{80}$ As such, it is an illustrative example of how the ideology of independence changes the conditions of our socialisation, but not, to be sure, our social conditioning itself - our dependency on some form of exterior influence is a transhistorical category.

The fourth and final aspect that I wish to address goes back to the first category and the changing ways in which the individual pupil was conceived during the period. A salient characteristic of the educational poli- 
cies during the postwar period was that of enhanced individualisation. ${ }^{81}$ To some extent, this was an inevitable dimension of the argumentation in favour of the Comprehensive School, serving as a riposte to those claiming that it would have levelling consequences. Indeed, the Swedish educational historian Gunnar Richardson even claims that it was a sine qua non for the reform..$^{82}$ The very structure of the new school thus embedded an individualising tendency into itself, making this one of its defining characteristics. One of many manifestations of this was the proliferation of the Deweyan method of "learning by doing" ${ }^{83}$ And although this method stretches far back to the 1940 s (in Swedish policy documents), there are clear signs of its intensification during the 1970s. One example in this regard was that earlier counter-weights, such as the importance of inculcating a sensibility for cultural heritage, disappeared from the relevant policy documents. ${ }^{84}$

A further example can be found in the handing over of influence to pupils in order to prepare them for democratic citizenship. In the same vein, but addressing different problems, were the instructions to further adapt school practices to accommodate the experiences that pupils brought with them to school. As the Social Democratic Government put it in the bill "on the inner work of the school":

The point of departure for the propositions is that municipalities and separate school units in the municipality should be given opportunities to adapt teaching to the pupils or group of pupils' needs [...] The school should to a larger degree than is currently the case endeavour to implement a way of working that relates to the reality of pupils. ${ }^{85}$

These changes, aiming at furthering the unfettered free development of the individual, should be understood as partly motivated by the political conviction of further emancipating the individual, and thereby enhancing equality. ${ }^{86}$

The dimension of Tocqueville's thought that I have referred to as democratic epistemology is primarily depicted as an impulse operating within each individual; it is a socially induced attitude that is fed to people in democratic societies at an early stage. Clearly, there is a difference in degree between this phenomenon and the shifts outlined in this section. What Tocqueville described as a socialised way of being had, in the postwar educational policy, been raised to a central policy aim - an officially promoted ideology. ${ }^{87}$ As such, elevated from a spontaneous order of interaction to a decree, it should, I maintain, be thought of as the epitome of the Tocquevillian themes outlined herein. How it can be fleshed out and understood from a broader political-philosophical perspective is the subject of the concluding section. 


\section{Alterity, individualism and pointillistic liberty (v)}

In reactivating Tocqueville's reflections on democratic equality, I have sought to extract some strands of continuity in the Swedish postwar political landscape that have gone relatively unnoticed until now. Via the four categories, I have argued that a number of politically relevant facets of the educational reforms can be understood as, at least partly, internally engendered impulses. ${ }^{88}$ Emphasising a number of central dimensions of postwar educational policies, I have argued that, in various ways, they evince a tendency to weaken political bonds and to strengthen interestdriven ones. The democratic epistemology, temporal provincialism, and intimisation of upbringing all converge in a tendency to have individuals retreating into themselves, nourishing the belief "that their destiny is entirely in their hands". ${ }^{99}$ Moreover, as indicated in the final lines of the previous section, the fact that these social impulses have been raised to the status of officially imposed norms clearly indicates an even closer interlacing between them and societal development.

In the introduction, I defined the democratic equalisation of conditions as a force that negates alterity. In contrast to previous societies, which were structured around explicit, collective, normative ideals, against which individuals oriented themselves, democratic society has successively undermined this structure. As such, it stands in stark contrast to hierarchical societies, where an order was imposed that integrated "the society with reference to values", and thereby to something other than the individual..$^{90}$

In its place, varieties of individually based normative patterns have been, and certainly continue to be, vindicated. Besides the private property right, other negative, "bourgeois" liberties and rights have been added, and since the second half of the $19^{\text {th }}$ century, positive rights have successively been added. In my view, what makes Tocqueville such a germane thinker for comprehending our situation is that he provides analytical categories for understanding how critique that emerges from different political camps has furthered the idea of the unfettered individual. ${ }^{91}$ His reflections thereby allow for historically anchored ways of approaching the tension - intrinsic to the modern project - between private rights and various forms of collective freedom and individual liberty, most notably the dialectics between individual and collective autonomy. ${ }^{92}$

The undermining of alterity is, I would argue, also the thread that draws together the policy changes explored above. The implicit bent to dismantle the idea of authority, the scepticism towards the disinterested (as opposed to that which serves a practical purpose) and towards engagement with 
the abstract and theoretical, to increasingly focus on what is present, to promote the natural on behalf of the artificial (in the specific sense in which Tocqueville defines it) can all be thought of as manifestations of a hostility to alterity. ${ }^{93}$ The disassembling of qualitative distinctions and the enhanced importance of the present appear rather straightforward in their direct scepticism towards time-bound and person-bound otherness. ${ }^{94}$ Regarding the abstract, one could think of this as an example of alterity owing to its time-demanding, imperative and subjectifying character; treading their inaccessible paths, without any fixed terminus, requires subjecting oneself to their premises, and this in turn presupposes the acceptance of an initial degree of inequality. Without presupposing this gap, there is nothing to surmount, and thus it becomes difficult to see the point in undertaking "the fatiguing climb of its steep paths", while its promised "luminous summits" will tend to appear like the endeavours of a bigot. ${ }^{95}$

When, on the contrary, the all-encompassing end is practical and mercantile interest and the concrete benefits that result therefrom, the act of submission appears in a rather different light. Vindicating the applicability and/or concrete utility, it remains within the horizon of the I, of the individual and what is graspable from her private horizon. As such, it appears acceptable also in societies immersed in the democratic order outlined above. As noted, Tocqueville does not claim that individuals will cease to interact with each other; rather that they will be increasingly prone to relate to each other through bonds knitted via mutual interests.

In light of the fact that dependence on opinions will not dissipate "in the ages of democracy" either - it is a transhistorical premise - the following question then arises: whence is authority exercised ${ }^{96}$ This is where the Tocquevillian themes outlined here tie in with Michel Foucault's analysis of the emergence of a new form of governmentality during the $18^{\text {th }}$ century, and which was further intensified in the $20^{\text {th }}$ century, incarnated by thinkers such as Gary Becker who focus on the idea of human capital. The crumbling of the manifest spiritual authority that in the past was exercised to a larger extent in, for example, schools thus stands in a negative relation to the subtler but deeply influential force of man as an entrepreneur of himself; as the former has withdrawn, the latter has expanded. ${ }^{97}$ Moreover, in line with what has been argued above, this is in conformity with other aspects of the democratisation of society highlighted by Tocqueville, such as the tendency towards more interest-driven social relations, and the shift towards an education that is guided more by economic values and utility. This is a revealing example of how the Tocquevillian themes, when taken together, elucidate how the cited policy changes can be interlaced with the explicit instruction to address the pupils as potential entrepreneurs. ${ }^{98}$ 
In Tocqueville's day, democratisation was still in its relative infancy, and as a consequence the "spirit wander[ed] in obscurity". ${ }^{99}$ The current situation is different. Concerning the questions discussed here, 70 years of dismantling the tradition-bound school in Sweden provide a substantial space of experience on which to draw - and hopefully also to extend our horizon of expectation. ${ }^{100}$ From this point of view, the historical preconditions of a reflexive re-embedding of education in time, i.e. of the traditions that we make ours, hereby articulating man in both the singular and the plural, have perhaps never been better. ${ }^{101} \mathrm{My}$ argument is thus that the fierce negating critique of tradition tout court invites us to reconsider what a re-embedding of the tradition could mean; as such, it can be seen as an invitation to a constructive negation of the annihilating critique that since the 1970 s has dominated the school political landscape. ${ }^{102}$ Approaching education in this way would seem to open up new avenues for an ideal of equality envisaged over time, in contrast to the time-contracting imaginary equality, thereby enlarging the horizons of the individual pupil as well as the political community out of which the former emerges.

\section{Noter}

1. As the Swedish historian Johan Östling has convincingly argued, the experiences of totalitarian regimes further added to the endeavour to create a more democratic educational system. See: Johan Östling: Nazismens sensmoral: svenska erfarenheter $i$ andra världskrigets efterdyning (Lund, 2008).

2. Mattias Börjesson, Från likvärdighet till marknad: en studie av offentligt och privat inflytande över skolans styrning isvensk utbildningspolitik 1969-1999 (Örebro, 2016); Tomas Englund (ed.), Utbildningspolitiskt systemskifte? (Stockholm, 1996); Tomas Englund, "Education as a Citizenship Right - A Concept in Transition: Sweden Related to Other Western Democracies and Political Philosophy" in Journal of Curriculum Studies, 26:4 (1994), 383-399; Gunnar Richardson, Svensk utbildningshistoria: skola och samhälle förr och $n u$ (Lund, 2010).

3. Kristina Boréus, Högervåg: nyliberalismen och kampen om språket 1969-1989 (Stockholm, 1994); Peter Antman, Göran Greider \& Tomas Lappalainen (eds.), Systemskifte: fyra folkhemsdebatter (Stockholm, 1993); Anders Ivarsson Westerberg, Ylva Waldemarsson \& Kjell Österberg (eds.), Det långa 1990-talet: när Sverige förändrades (Umeå, 2014).

4. Ulf P. Lundgren, Att organisera omvärlden. En introduktion till läroplansteori (Stockholm, 1979), 116. The previous analyses referred to are: Piero Colla, L'héritage impensable (Paris, 2017); Tomas Wedin, "In Praise of the Present", History of Education 46:6 (2017), 768-787; Tomas Wedin, "The Aporias of Equality" in Confero 5:1 (2017), 193-241. Although without predecessors in Sweden, Tocqueville has more recently been adduced in education policy analyses. See: Steven Connolley \& Rune Sarromaa Hausstätter, "Tocqueville on Democracy and Inclusive Education: A More Ardent and Enduring Love of Equality than of Liberty" in European Journal of Special Needs Education 24:3 (2009); Pierre Statius, De l'éducation des modernes: Réflexions sur la crise 
de l'école à l'âge démocratique (Paris, 2009). On Google Scholar, the keywords "Tocqueville" and "education" in the title yield 23 results (March 2017), of which 5 are related to the debate that emerged in the wake of Connolley \& Hausstätter's article. In France, Marcel Gauchet has written a number of books approaching the educational system from a kind of Tocquevillian perspective. Tocqueville himself never wrote anything more substantial on education in the democratic society that he successively saw replacing the earlier aristocratic society. The closest we get to an explicit confrontation with the issue is the chapter 'Éducation de jeunes filles aux États-Unis' in Alexis de Tocqueville, De la démocratie en Amérique 2 (Paris, 1981 [1840]). However, for the purposes of this article, this chapter is of no particular relevance.

5. Positive rights would include a right to education, unemployment benefits, etc., whereas negative rights evoke the classical liberal right to non-interference, etc.

6. Colla, L'héritage impensable; Wedin: "In Praise of the Present"; Wedin, "The Aporias of Equality".

7. "[...] un entrepreneur de lui-même", Michel Foucault, La naissance de la biopolitique (Paris, 2004), 232. As has been shown, this has become a structuring educational ideal for at least a decade (Magnus Dahlstedt, "The Swedish Road to Democracy? Governmentality, Technologies of Citizenship and Popular Movements" in ThemES - Themes on Migration and Ethnic Studies 30 (2009); Magnus Dahlstedt \& Fredrik Hertzberg, "Den entreprenörskapande skolan: styrning, subjektsskapande och entreprenörskapspedagogik" in Pedagogisk forskning i Sverige 16:3 (2011); Tomas Wedin, "The Rise of Knowledge School and its Relation to the Resurrection of Bildung" in Nordic Journal of Educational History 2:2 (2015), 49-67.

8. "[...] le sentiment partagé d'une offense faite au temps par la Révolution”, Frédéric Brahami, La raison du people (Paris, 2016), 26.

9. "les bâtisseurs du temps", Brahami, La Raison du peuple, 25. Another way to comprehend this is to envision it as an extreme form of the separation between space of experience and horizon of expectation that Koselleck has outlined. See: Reinhart Koselleck, Futures Past: On the Semantics of Historical Time (New York, 2004 [1979]), 263.

10. For Tocqueville, the focus was directed against the process of democratisation, preceding the revolution by centuries, whereas the attempt to break with the past for many other writers was related to the revolution and the abstract reason throughout the lumieres (Brahami, La raison du people, 276-277). Independently of their differing focus, they all - Tocqueville included - shared a fear of the nihilism that they associated with a dis-embedded abstract critique of society. Indeed, as Brahami writes, many of the sociological theses he is associated with today - such as his reflections on the form of equality, the tentacular state, the apathy of the people and even the continuity between the l'Ancien régime and Revolution - were considered "commonplaces of the time" among his contemporaries (Brahami, La raison du peuple, 279).

11. The analogy between anthropology and history is discussed by Louis Dumont in Homo hierarchicus (Paris, 1992 [1966]), 13-35.

12. Between the hierarchical past in which he was deeply immersed, with renowned precedents such as Vauban and Malesherbes, and the democratic society that he saw successively replacing the world that his family tree represented, Tocqueville was particularly well placed for articulating the challenges posed by a democratic society. See: Sheldon Wolin, Tocqueville Between Two Worlds: The Making of a Political and Theoretical Life (Princeton, NJ, 2001). 
13. "j'y ai cherché une image de la démocratie elle-même, de ses penchants, de son caractère, de ses préjugés, de ses passions; j'ai voulu la connaître, ne fût-ce que pour savoir du moins ce que nous devions espérer ou craindre d'elle", Tocqueville, De la démocratie en Amérique 1 (Paris, 1981 [1835]), 69. Essentially, the same intention is repeated in the introduction to the second book, published five years later in 1840 .

14. Compare with: Aristotle, Politics (Indianapolis/Cambridge, 1998), Book III.

15. Tocqueville, De la démocratie en Amérique 2, 5

16. Tocqueville, De la démocratie en Amérique 2, 120. As Montesquieu writes: "Il y cette différence entre la nature du gouvernement et son principe, que sa nature est ce qui le fait être tel, et son principe ce qui le fait agir. L'une est sa structure particulière, et l'autre les passions humaines qui le font mouvoir" (Montesquieu, De l'esprit des lois (Paris, 1979 [1748]), book III, chapter 1).

17. "[...] qu'après avoir détruit la féodalité et vaincu les rois, la démocratie reculera devant les bourgeois et les riches? S'arretêra-t-elle maintenant qu'elle est devenue si forte et ses adversaires si faibles ?", Tocqueville, De la démocratie en Amérique 1, 61.

18. Tocqueville, De la démocratie en Amérique 2, $199 \mathrm{ff}$.

19. "[...] l'inégalité des intelligences, qui, venant directement de Dieu, échappera toujours aux lois", Tocqueville, De la démocratie en Amérique 2, 173.

20. This, argues Aron, is the dynamic that makes modern society not only something that is in process, but a process in itself. See: Raymond Aron, Progress andDisillusion: The Dialectics of Modern Society (New York, 1968 [1965]), 3-4. Tocqueville demonstrates an awareness of the possibilities of a new "industrial aristocracy" in Tocqueville, $D e$ la démocratie en Amérique 2, chapter 20, book two.

21. Where some of the more prominent participants in the discussion are: Claude Lefort, Essais surle politique: XIX-XXe siècles (Paris, 2005); Marcel Gauchet, La condition politique (Paris, 2005); Aron Progress and Disillusion; Dumont, Homo hierarchicus; Louis Dumont, Homo aequalis I (Paris, 2008 [1977]).

22. "[...] discernable en soi, au-dedans de chacun d'eux pris en particulier. Il tient à la façon, socialement définie, dont ils se rencontrent et se situent les uns vis-à-vis des autres - à la structure d'une relation qui les détermine [... ]", Gauchet, La condition politique, 350-351. This depiction corresponds neatly to how Manent explains his interest in Tocqueville's thought as well. See: Pierre Manent, Le regard politique (Paris, 2010), 130-131. For a more elaborate discussion of Tocqueville in Manent's thought, see: Pierre Manent, Tocqueville et la nature de la démocratie (Paris, 2012 [1982]).

23. "[...] une sorte d'égalité imaginaire, en dépit de l'égalité réelle de leurs conditions", Tocqueville, De la démocratie en Amérique 2, 226. Gauchet evokes the idea of this form of equality as a "central imaginary signification" as defined by Greek-French philosopher Cornelius Castoriadis.

24. Dumont, Homo hierarchicus, 318.

25. "Sous l'ancien régime comme de nos jours, il n'y avait ville, bourg, village, ni si petit hameau en France, hôpital, fabrique, couvent ni collège, qui pût avoir une volonté indépendante dans ses affaires particulières, ni administrer à sa volonté ses propres biens. Alors comme aujourd'hui, l'administration tenait donc tous les Français en tutelle, et si l'insolence du mot ne s'était pas encore produite, on avait du moins déjà la chose", Alexis de Tocqueville, L'ancien régime et la revolution (Paris, 1988 [1856]), $145^{-146 .}$

26. Tocqueville was persuaded that religious conviction is necessary. The content of such conviction, however, was seen as less crucial: "what is most important for it 
[society], is not that all citizens profess a true religion, but that they profess a religion", Tocqueville, De la démocratie en Amérique, 396. Religious beliefs, born out of a "natural disgust for existence, and an immense desire to exist", should as such, i.e. due to their existential character, be directed towards the hereafter (Tocqueville, De la démocratie en Amérique, 403).

27. "[...] sentiment réfléchi et paisible qui dispose chaque citoyen à s'isoler", Tocqueville, De la démocratie en Amérique 2, 125.

28. Tocqueville, De la démocratie en Amérique 2, 125.

29. "Lorsque les conditions sont égales, chacun s'isole volontiers en soi-même et oublie le public. Si les législateurs des peoples démocratiques ne cherchaient point à corriger cette funeste tendance ou la favorisaient, dans la pensée qu'elle détourne les citoyens des passions politiques et les écarte ainsi des révolutions, il se pourrait qu'ils finissent eux-mêmes par produire le mal qu'ils veulent éviter, et qu'il arrivât un moment où les passions désordonnées de quelques hommes, s'aidant de l'égoïsme inintelligent et de la pusillanimité du plus grand nombre, finissent par contraindre le corps social à subir d'étranges vicissitudes", Tocqueville, De la démocratie en Amérique 2,317 .

30. For a discussion relating the formal equality in Tocqueville's thought to both the contemporary critique of Karl Marx as well as to the dialectics between formal equality and the very real economic inequality in modern society, see: Aron, Essai sur les libertés; Aron, Progress and Disillusion; Aron, Dix-huit leçons de la société industrielle, 33-51; Aron, La lutte de classes, 94ff.

31. "[...] n'apercevant dans aucun d'entre eux les signes d'une grandeur et d'une supériorité incontestables [sic], [ils] sont sans cesse ramenés vers leur propre raison comme vers la source la plus visible et la plus proche de la vérité. Ce n'est pas seulement la confiance en tel homme qui est détruit, mais le goût d'en croire un homme quelconque sur parole", Tocqueville, De la démocratie en Amérique 2, 10.

32. "[...] voiles inutiles et incommodes placés entre eux et la vérité", Tocqueville, De la démocratie en Amérique 2, 11.

33. "[...] du tangible et du réel, le mépris des traditions et des formes", Tocqueville, De la démocratie en Amérique 2, 53 .

34. Reflections pointing in the same direction we also find in, e.g., the chapters treating the modifications of language and literature in the democratic society. See: Tocqueville, De la démocratie en Amérique 2, chapters XIII and XVII,

35. "[...] avides des jouissances matérielles et présentes [...] toujours mécontentes de la position qu'ils occupent [...]", Tocqueville, De la démocratie en Amérique 2,57 .

36. More specifically Tocquevillian in the sense that the materialist card could be related to, e.g., Marx's writings on commodity fetishism and a number of other traditions as well. A second possible explanation is of a more general character, and in line with many others who were writing on the emerging modern society (Brahami, $L a$ raison du peuple). In the chapter entitled 'How the aristocracy could come out of the industry', Tocqueville presents, apart from discussing the content of the title, a view on the expected paths of workers and industry. The subsequent phrase captures neatly the tone of the first half of the $19^{\text {th }}$ century: "we could say that in him [the worker], man degrades to the extent that the worker is perfected" (Tocqueville, De la démocratie en Amérique 2,199). In a society dominated by a dehumanised collection of proletarians and an elite interested primarily in advancing industry (and all of them 
oriented towards advancing in society), the outlook for pursuing the disinterested search for truth and contemplation is not very favourable.

37. As exemplified by the distinction between the ideal of Bildung and instrumental forms of education.

38. Tocqueville, De la démocratie en Amérique 2, 16. Leaving aside the fact that there are virtually endless streams of situations in which we are uninterested in examining how we ought to act.

39. A pattern Tocqueville sees as typical of pre-modern society, where individual authorities are the norm.

40. Tocqueville, De la démocratie en Amérique 2, $16 \mathrm{ff}$.

41. "Je vois clairement dans l'égalité deux tendances: l'une qui porte l'esprit de chaque homme vers des pensées nouvelles, et l'autre qui le réduirait volontiers à ne plus penser", Tocqueville, De la démocratie en Amérique 2, 18.

42. "L'indépendance individuelle peut être plus ou moins grande; elle ne saurait être sans bornes. Ainsi, la question n'est pas de savoir s'il existe une autorité intellectuelle dans les siècles démocratiques, mais seulement où en est le dépôt et quelle en sera la mesure", Tocqueville, De la démocratie en Amérique 2, 16.

43. This can be compared with Brahami's distinction between being in time and trying to assume the role of creators of time (compare p. 2 above).

44. Tocqueville, De la démocratie en Amérique 2, 10.

45. "Ainsi, non seulement la démocratie fait oublier à chaque homme ses aïeux, mais elle lui cache ses descendants et le sépare de ses contemporains; elle le ramène sans cesse vers lui seul et menace de le renfermer enfin tout entier dans la solitude de son propre cœur", Tocqueville, De la démocratie en Amérique 2, 127.

46. The idea of a provincialism of time is inspired by T.S. Eliot. See: T.S. Eliot, On Poetry and Poets (New York, 2009), 72.

47. When reading his reflections on the shifting time horizons, it is almost as if he would have navigated between all three, following François Hartog, regimes of historicity at the same time. See: François Hartog, Régimes d'historicité (Paris, 2012). In Tocqueville's thought, we first of all find a lamentation on a time when past, present and future generations were like contemporaries, and the past did illuminate the future, i.e. when men still drew lessons from the past in a predominantly circular way. In parallel, the narrative itself bears clear signs of a typically modern, future oriented regime of historicity: "I have wanted to look, not differently, but longer than the parties; and whereas they worry about tomorrow, I have pondered [songer] over the future" (Tocqueville, De la démocratie en Amérique 1, 71, my italics). As Hartog has shown, he hereby inverses the ancient schema, making the future the guide of the present, rather than the past (Hartog, Régimes d'historicité, 131ff.). And then thirdly, on top of the pre-modern and modern approaches to history, his reflections over the expected expansion of the present, which best seem to fit with what Hartog defines as a presentist regime of historicity (Hartog, Régimes d'historicité, 149ff.).

48. Tocqueville, De la démocratie en Amérique 2, 245.

49. "La démocratie détend les liens sociaux, mais elle resserre les liens naturels. Elle rapproche les parents dans le même temps qu'elle sépare les citoyens", Tocqueville, De la démocratie en Amérique 2, 245. Clearly, the outlined impulse intersects with Foucault's writings on biopolitics and the new techniques of disciplining in, e.g., Foucault, Naissance de la biopolitique. To my knowledge, no one has so far scrutinised the closer affinities and differences between Foucault's writings on the modern forms 
of disciplining, Tocqueville's reflections on the process of democratisation and its relation to the ever more influential state, and finally Arendt's reflections on the rise of what she terms the social.

50. Which in turn are sometimes, depending on the approach of different authors, divided into more nuanced periodisations, in particular the period 1946-1990.

51. See quote 2 above.

52. Börjesson, Från likvärdighet till marknad; Englund et al. (eds.), Utbildningspolitiskt systemskifte?; Englund, "Education as a Citizenship Right", 383-399; Lisbeth Lundahl, Inger Erixon Arreman, Ann-Sofie Holm \& Ulf Lundström, "Educational Marketization the Swedish Way" in Education Inquiry 4:3 (2013), 497-517.

53. Shirin Ahlbäck Öberg, Thomas Bull, Ylva Hasselberg \& Niklas Stenlås, "Professions Under Siege" in Statsvetenskaplig tidskrift 118:1 (2016), 93-126.

54. Gert Biesta, "Against Learning: Reclaiming a Language for Education in an Age of Learning" in Nordic Studies in Education 25:1 (2005), 54-66; Gert Biesta, Bortom lärandet: demokratisk utbildning för en mänsklig framtid (Lund, 2006).

55. Tage Erlander, Tage Erlander 1940-1949 (Stockholm, 1973), 233.

56. SOU 1948:27, 1946-års skolkommissions betänkande med förslag till riktlinjer för det svenska skolväsendets utveckling, $5 ; 354$.

57. SOU 1948:27, 1946-ärs skolkommissions betänkande, 1. For an analysis of how the Second World War and the experiences of totalitarian regimes affected postwar educational policies as well as policies more generally in Sweden, see: Östling, Nazismens sensmoral: svenska erfarenheter $i$ andra världskrigets efterdyning.

58. Lindensjö \& Lundgren, Utbildningsreformer och politisk styrning; Johanna Ringarp, Professionens problematik: lärarkårens kommunalisering och välfärdsstatens förvandling (Stockholm, 2011), 48-49; Ninni Wahlström, Om det förändrade ansvaret för skolan (Örebro, 2002), 207-208.

59. Richardson, Svensk utbildningshistoria: skola och samhälle förr och nu, 14, 138-140.

60. The subsequent notes all draw on what is developed at greater length in: Wedin, "In Praise of the Present"; Wedin, "The Aporias of Equality".

61. "[...] egentliga yrkesutbildningen i stor utsträckning bör göras gemensam för alla lärarkategorier", SOU 1948:27, 1946-års skolkommissions betänkande: 363 . Formulations in the same spirit were then rearticulated in the report on teacher training that was presented a few years later as a consequence of the suggested reforms of the school, SOU 1952:33, Den första lärarhögskolan: betänkande utgivet av 1946-års skolkommission, 7 ff.

62. "[...] vara härdar för progressiv pedagogik", SOU 1948:27, 1946-års skolkommissions betänkande, 410; SOU 1952:33 1946-års skolkommissions betänkande, 24.

63. Bill 1999/2000:135, En förnyad lärarutbildning.

64. Wedin, "In Praise of the Present"; Wedin, "The Aporias of Equality".

65. "[...] blir mer stödjande och stimulerande än direkt kunskapsförmedlande", SOU 1978:86, Lärare för skola i utveckling: betänkande av 1974 års lärarutbildningsutredning, 24.

66. “[...] något man skaffar sig i en demokratisk process", Bill 1999/2000:135, En förnyad lärarutbildning, 8.

67. Bill 1975/76:39, om skolans inre arbete m.m., 1-2; Karin Hadenius, Jämlikhet och frihet: politiska målför den svenska grundskolan (Uppsala, 1990), 254ff; Wedin, "In Praise of the Present".

68. Wedin, "The Aporias of Equality". 
69. This is along the lines of how Arendt argues in 'Crisis in Education', writing that the school should be considered "the institution that we interpose between the private domain of home and the world in order to make the transition from the family to the world possible at all", Hannah Arendt, Between Past and Future (London, 2006), 185. Regarding the assumed time dimension in her argumentation, i.e. that the school should prepare the pupils for a future life as political equals, Gert Biesta has written a clarifying analysis of Arendt's approach. See: Gert Biesta, "How to Exist Politically and Learn From it: Hannah Arendt and the Problem of Democratic Education" in Teachers College Record 112:2 (2010), 556-575.

70. As such, it seems to coincide with the alleged therapeutic turn in educational policies since the 1960s. See: Philip Rieff, The Triumph of the Therapeutic: Uses of Faith After Freud (New York, 1966); Christopher Lasch, The Culture of Narcissism (New York, 1979); Kathryn Ecclestone, "Resisting Images of the "diminished self": The Implications of Emotional Wellbeing and Emotional Engagement in Education Policy" in Journal of Education Policy 22:4 (2007); Kathryn Ecclestone \& Dennis Hayes, The Dangerous Rise of Therapeutic Education (London, 2009); Frank Furedi, Wasted: Why Education isn't Educating (London, 2009); Paul Smeyers, Richard Smith, \& Paul Standish, The Therapy of Education: Philosophy, Happiness and Personal Growth (Basingstoke, 2010). As the intellectual historian Thomas Karlsohn argues, it would nevertheless seem deceptive to conceive of this as a tension between emotions (which would be dangerous, misplaced), and the Reason proper for education. The apposite question is rather how the dynamics between emotions and reason can be reconceived in order to improve the educational system. See: Thomas Karlsohn, "On Emotions, Knowledge and Educational Institutions" in Confero 4:1 (2016). Compare also the distinction I have drawn elsewhere between two emotional logics: Tomas Wedin, "Education and Emotions: From One Emotional Logic to Another" in Conference Proceedings. The Future of Education (Florence, 2018).

71. Colla, L'héritage impensable; Wedin, "The Aporias of Equality".

72. Bill 1999/2000:135, En förnyad lärarutbildning.

73. A dimension that is further discussed in Wedin, "In Praise of the Present".

74. SOU 1965:29, Lärarutbildningen: 1960 års lärarutbildningssakkunniga, 83; SOU 1978:86, Lärare för skola $i$ utveckling: 78-79. With the advent of the communication revolution, and emergence of the Internet in particular, yet another argument was added to those sceptical of a content-oriented form of teaching.

75. SOU 1992:94, Skola för bildning: huvudbetänkande av läroplanskommittén, 67.

76. “[...] varken något yttre eller inre, utanför människan, eller något inre, inne i individen, utan snarare någonting som ligger mellan individen och omgivningen. En viktig del av denna omgivning är andra människor, det sociala sammanhang där kunskapen kommuniceras inom språket." For a closer analysis of the specific form of constructivist ideas of knowledge and their role in Swedish educational politics during the 1990s, see: Jonas Linderoth, Lärarens återkomst: frän förvirring till upprättelse (Stockholm, 2016).

77. These tendencies towards a stronger emphasis on the present can be thought of as indications of a successive shift in how a given society, to borrow the expression from Hartog, develops in time. See: Hartog, Régimes d'historicité. With development in time, he refers to the implicit temporal horizons that during different historical epochs have structured human societies. Hartog's concept of regimes of historicity can, as I have argued elsewhere, be used to illuminate the changes out- 
lined in the paragraph above: Wedin, "In Praise of the Present". See footnote 47 for further remarks on how different temporal horizons are operative in Tocqueville's thought.

78. "[...] jag-förverkligande, gemenskapsupplevelser och gemensamt solidariskt arbete i nuet", SOU 1978:86, Lärare för skola i utveckling, 78.

79. This side of the changes ties in with how Raymond Aron has argued, when claiming that the full realisation of the modern ideal of equality seems to "imply a social order strictly nonhereditary in character and devoid of any continuity", Aron, Progress and Disillusion, 3.

80. For a reflection on the consequences of this, see Arendt's reflections in 'Crisis in Education', in: Arendt, Between Past and Future.

81. Joanna Giota, "Individualiserad undervisning i skolan: en forskningsöversikt", Vetenskapsrådets rapportserie (Stockholm, 2013); Monika Vinterek, "Individualisering i ett skolsammanhang" in Forskning i fokus 31 (2006); Wedin, 'In Praise of the Present'.

82. Richardson, Drömmen om en ny skola, 154.

83. For a clarifying analysis of John Dewey's educational philosophy and the misuses of it, see: Tove Österman, "Vad är det att kunna? Dewey och flumskolan", in Gustavsson, Hållén \& Österman (eds.), Vad ska en svensk kunna? Utbildningens dilemma - intressenas spel (Göteborg, 2016).

84. Wedin, 'In Praise of the Present', compare also: Olle Widhe: "Estetisering och avestetisering: Nedslag i de svenska läroplanernas tal om läslust från 1906 till 2011", in Egeland, Olin-Scheller, Tanner \& Tengberg (eds.), Tolfte nationella konferensen $i$ svenska med didaktiska inriktning (Karlstad, 2016), 90.

85. "Utgångspunkten för förslagen är att kommuner och skolenheterna i kommunen bör ges möjlighet att anpassa undervisningen efter enskilda elevers eller grupp av elevers behov [...] Skolan bör i högre grad än f.n. sträva efter ett arbetssätt som knyter ant $[$ sic $]$ till elevernas verklighet", Bill 1975/76:39, om skolans inre arbete m.m, 1.

86. Colla, L'héritage impensable; Wedin, "In Praise of the Present"; Wedin, "The Aporias of Equality".

87. And ever since it was proclaimed as the overarching aim by the school commission of 1946, the educational policies have vacillated between the two extremes of what Aron names the dialectics of equality: a tension between the "promethean" ambition to maximise the production of goods and the endeavour to equalise conditions, Aron, Progress and Disillusion, 3.

88. Of which it does not evidently follow that other forces also have not influenced the policy development. My claim is that the egalitarian impulses highlighted here are one dimension that elucidates the changes, not that it is the exclusive and overriding force. Clearly, the shift from quality to quantity was a pivotal question for other interpreters of modernity as well, in particular Marx.

89. "[...] que leur destinée tout entière est entre leurs mains", Tocqueville, De la démocratie en Amérique 2, 127.

90. “[...] la société par référence aux valeurs", Dumont, Homo hierarchicus, 318.

91. Even if Sweden is an extreme example, the development occurs in comparable countries, albeit the contrasts are less harsh. As to what concerns the affinities between this dominant form of liberalism and a wider liberal tradition, this is a development that primarily seems to be anchored to the uprooted physicalist liberal tradition, which since the $18^{\text {th }}$ century has gained ground at the expense of other traditions, Larry Siedentop, Inventing the Individual: The Origins of Western Liberalism (Cambridge, MA, 
2014), 337-338. Besides Siedentop, a number of other prominent thinkers have contributed to emphasising this from different angles: Brahami, La Raison du people; John Milbank \& Adrian Pabst, The Politics of Virtue: Post-liberalism and the Human Future (London, 2016), but the list could be made much longer.

92. For an illuminating discussion of the difference between freedom and liberty, see: Hanna Fenichel Pitkin, "Are Freedom and Liberty Twins?" in Political Theory 16:4 (1988), 523-552. As such, his way of tackling the contradictions of modernity offers a potentially rich contrast to Marx's reflections on the same problems, as well as Fredric Jameson's much more recent work in the same tradition, see: Fredric Jameson, Postmodernism, or, The Cultural Logic of Late Capitalism (London/New York, 1992).

93. For an interesting attempt to think with and against Tocqueville, see: Mark Reinhardt, The Art of Being Free (New York, 1997), primarily chapters 2 and 3.

94. The reflection is in a similar vein to the distinctions made by Louis Dumont, a French anthropologist who was deeply inspired by Tocqueville. Approaching the egalitarian society via a geographical detour, Dumont spent 20 years in India studying the caste society and later wrote a number of texts reflecting on the differences between the different societies. Together with Aron and Furet, he played a pivotal role in reactivating Tocqueville in the postwar period: Serge Audier, Tocqueville retrouvé (Paris, 2004); Manent, Le regard politique. In line with Tocqueville, Dumont considered individualism a form of ideologeme that rendered the increased hostility to authorities understandable. The egalitarian society does not preclude difference, but will contain inequalities within itself rather than having them structured in a hierarchy (Dumont, Homo hierarchicus, 323). The notable inequalities will be accepted "under the condition that these differences are morally neutral" (Dumont, Homo hierarchicus, 322). This should be contrasted with the hierarchical society, which is characterised by its non-material and symbolic meaning, serving as a guiding principle for the unity of society.

95. Karl Marx, Capital, Volume 1 (London, 1990 [1867]), 104 (preface to first French edition, 1872-75).

96. "[...] dans les siècles démocratiques", Tocqueville, De la démocratie en Amérique $2,16$.

97. Along the lines of how Arendt argues in 'What is Authority?', the possible alternative definition of "authority of market" would seem like an oddity, since the influence exercised by the market is not of this symbolically erected character, see Arendt, Between Past and Future. For Foucault's reflections on these themes, see: Foucault, La naissance de la biopolitique; Michel Foucault, Sécurité, territoire, population (Paris, 2004).

98. And it is an indication of how deeply immersed we are in this rights-based, atomistic liberalism that a devastating majority of today's liberals would not even define our predicament as a tragic situation, i.e. where the "impossible and the necessary join", Vladimir Jankélévitch, L'Alternative (Paris, 1938), 150.

99. “[... ] l'esprit marche dans les ténèbres”, Tocqueville, De la démocratie en Amérique 2, 399 .

100. However, from a wider perspective it can be argued that we have almost 200 years of experience of the tension between tradition (in the form of the role of Latin in the educational system) and the role of more utility-oriented subjects.

101. Viewed from a narrow educational historical perspective that is; when taking 
TOCQUEVILLE, EQUALITY AND INDIVIDUALISATION • 97

other aspects into consideration, such as the current political landscape, the matter appears in a rather different light.

102. In some respects, the attempt to reactivate Bildung as a central idea for the reformed school in the 1992 report, named School for Bildung, could be considered an early - albeit failed - attempt to do precisely this. 



\section{Appendix IV: "Educational Equality: A Politico-Temporal Approach”}





\section{Educational Equality: A Politico-Temporal Approach}

(Journal of Philosophy of Education, under review)

A crisis forces us back to the questions themselves and requires from us either new or old answers on which we ordinarily rely without even realising they were originally answers to questions. A crisis becomes a disaster only when we respond to it with preformed judgements, that is, with prejudices. Such an attitude not only sharpens the crisis but makes us forfeit the experience of reality and the opportunity for reflection it provides (Arendt, 2006a, p. 171).

In the attempt to modernise post-war Swedish society and establish a rational and democratic societal order, which was expected to serve as a rampart against the irrational exuberance supposed to have contributed to the rise of Nazism and other fascist regimes, a veritable war was launched against anything related to the old society. Nationalism, outdated hierarchies, symbolism and ritualism on all societal levels became prime targets for the reformists' zeal. As the Swedish historian Alf W. Johansson described it, the "whole ideological sphere related to the concept of community was punctuated" (Johansson, 1995, p. 226f.). ${ }^{1}$ One of the prioritised targets was the foundational institutions via which society was reproduced. The very raison d'être of elementary institutions - such as the family, the church, and the educational system - thereby came under attack; all vestiges of the "mythisistic" and superstitious past would now be purged, leading the state towards the future as part of a more rational and democratic order (Hirdman et al., 2012, p. 398). ${ }^{2}$

"Hela den ideologiska sfär som knutits till begreppet gemenskap punkterades".

2 As the Swedish historian Johan Östling points out, this is a clear example of how what Koselleck observed as the dialectic between space of experience and horizon of expectation interact, in these formative years to form a ground for politics for decennia to come (Östling, 2008). 


\section{APPENDIX IV}

Exemplary of this process was the democratisation of the educational system, in particular its effects on how the relationship between the individual and the collective was transformed. Throughout the post-war period, a successive shift of emphasis took place from an order in which the pupil was expected to be incorporated into an existing political community (in whichever form it was envisioned), to one in which the individual pupil was expected to be addressed in her particularity (Colla, 2017; Fernández, 2012; Lundgren \& Lindensjö, 2014; Wedin, 2017a). ${ }^{3}$

In a number of more recent studies, this turn towards the individual has been interlaced with a parallel change in how Swedish society deploys itself in time (Colla, 2017; Landahl, 2015; Wedin, 2017a; Wedin, 2017b). ${ }^{4}$ Following the lead of the French historian François Hartog in this regard, these transmutations can be considered as a move away from a forward oriented "regime of historicity" - a term he uses to signal how a society deploys itself in time - and towards a presentist regime (Hartog, 2012; Hartog, 2016; Wedin, 2017a).

Against this backdrop, with the Swedish case serving as an exemplar for exploring a more general problem, I have two aims with the current article. I begin the analysis by fleshing out an idea presented in previous research, namely that the successive shift to a presentist regime of historicity appears to be intertwined with a specific form of equality. Building on what I have argued elsewhere, I contend that a form of "imaginary" [imaginaire] equality, in Alexis de Tocqueville's formulation, seems to have contributed to the retrenchment of our temporal horizons, i.e. our condition of presentism (Wedin, 2017a; Wedin, 2018). I argue that the two phenomena - the imaginary equality and the condition of presentism - ought to be read in parallel and seen as a single politico-temporal problem.

Whereas previous research has focused on presentism as a historical category, the first purpose of the present article is to elaborate on how we could envisage the relationship between this form of equality, and the present as the dominant temporal horizon from a political-theoretical perspective. To do so, I will first compare the outlined form of equality with other, more well-established forms of equality. Thereby, I wish to underline the importance of the temporal dimension in current political-theoretical debates on the role of equality in educational policies, and the political paradoxes that the imaginary equality engenders. ${ }^{5}$ Then, in an attempt to address the

3 Clearly, this shift of emphasis is confined neither to the educational system as a societal sphere, nor to Sweden geographically, but rather forms part of a more general process of individualisation (Beck, 2001; Bauman, 2001; Inglehart, 1990).

4 The idea of deploying in time is explained in the ensuing section.

5 In reverse, I hereby inevitably also highlight political-theoretical aspects of the historiographical reflections on our ways of orienting in time as a community. Nevertheless, the 
politico-temporal aporia that emerge out of the imaginary equality, the second purpose is to argue that Hannah Arendt's reflections on education and political theory offer us useful conceptual tools to tackle the aporia discerned in the first part. In particular, I emphasise the temporal dimension of her contention that the paramount task of the educational system is to introduce the pupils to what she refers to as the world.

The analysis will proceed in six movements. In the first section, I show how the emergence of a presentist regime of historicity has been related to the expansion of a new form of equality within the educational system. In the second section, I expand the results from previous studies by framing how the pertinent concept of equality ties in with two more common forms of equality in the Western political tradition: the conceptions of formal and real equality. In the third section, I elucidate the explanatory force of the imaginary form of equality by drawing on previous studies of the metamorphoses of the Swedish educational system in the post-war period. The Swedish case serves as an exemplar for a more general tendency in educational policies in Western world; it also acts as a bridge leading over to the constructive approach set out in the fifth section. The key tendency I want to highlight is the politico-temporal paradox that emerges out of the imaginary equality. Thereafter, in the fourth section, I expound the politicotemporal contradictions that this imaginary form of equality seems to engender. Here I will draw on the French philosopher Marcel Gauchet's wide-ranging reflections on the inherent contradictions of democratic society. ${ }^{6}$

In the fifth movement, the deadlocks outlined in the preceding part will be addressed in a more constructive fashion by mobilising Hannah Arendt's educational and political thought. I argue that her politico-temporal way of approaching the question of education opens up space for a politically more fruitful way of envisioning equality. As we shall see, one of the crucial differences between the imaginary form of equality and the political conception of equality delineated in the fifth section is precisely the diverse temporal logics that they open up and towards which they gravitate. In the sixth and final section, I briefly summarise and conclude my findings.

primary aim of the article is to elucidate how historiographical reflections can contribute to our understanding of the educational system as a political-theoretical problem, not as a historiographical problem.

6 My usage of Gauchet is here strictly instrumental: I make use of his analysis here because it offers a good overview of the problem at hand, without foreclosing various ways of interpreting this general way of depicting the problem. 


\section{APPENDIX IV}

\section{The Condition of Presentism}

With a regime of historicity, Hartog wishes to capture the way in which a society, or in a wider sense a cultural sphere, deploys itself in time. He aims to show how an abstract cultural and/or political entity relates to the past, the present, and the future. With the emergence of History (with a capital $\mathrm{H}$ ) and the concomitant idea of progress in the second half of the $18^{\text {th }}$ century, the future increasingly became the dominant temporal horizon. In the $20^{\text {th }}$ century, Hartog continues, the future was successively conflated with the present. However, while this process of amalgamation initially tended to prioritise the future, during the second half of the century, it was the present that became the dominant temporal horizon, the structuring regime of historicity (Hartog, 2012, p. 149ff.; Hartog, 2016). ${ }^{7}$

This does not, according to Hartog, entail that the present is an invention of late modernity. Quite the contrary; he is at pains to show how the temporal horizon of the present has also been central in previous periods (albeit in very different ways). What is specific with regard to the $20^{\text {th }}$ century, and in particular the latter half, is how the present emerged as the dominant temporal modus in which the Western cultural sphere oriented itself. In a similar vein to the work of Hartmut Rosa, Hartog emphasises how the present as a dominant temporal horizon is entwined with the future-oriented regime, as manifested in e.g. the Futurist movement (Hartog, 2012, p. 149f; Rosa, 2009).

Against these broad historico-political strokes, the Norwegian philologist Helge Jordheim has noted that it would be a mistake to conceive of a "regime of historicity" as a monolith, as a definite and omnipotent force precluding simultaneous temporalities (Jordheim, 2012). This is an important clarification. As such, and taking inspiration from the recent work of a number of researchers from various theoretical traditions, I maintain that the proper way to think of our presentist regime of historicity is to think of it as precisely the dominant (which is not to say only) temporal horizon (Hartog, 2012; Hassan, 2009; Rosa, 2009; Harvey, 1991; Jameson, 2009; Lübbe, 2009).

There is an ongoing debate as to the causes behind, or the conditions of possibilities for, this successive shift from a modern future-oriented regime to an increasingly presentistic regime. Among the potential factors, three are especially pertinent. One influential current of interpretation, propoun-

\footnotetext{
Drawing on Reinhart Koselleck's research, Hartog furthers the former's analysis of the emerging ways to deploy in time in Europe during the period between roughly 1750-1850, by way of claiming that - at least in the Western world - the ever-expanding horizon of the present seems to indicate a shift from the future-oriented perspective that took form between 1750-1850 (Koselleck, 2004, p. 97ff).
} 
ded by e.g. Fredric Jameson and David Harvey from within a wider Western Marxist tradition, holds that such a temporal shift is structurally related to the transmutations of the capitalist system: from the typically production-oriented phase of modernity, to a predominantly consumeroriented phase from the 1960s, or the 1970s in the case of Harvey, and onwards (Jameson, 1992; Jameson, 2009; Harvey, 1991). A second dimension, which Hartog takes up, is that a growing awareness of the intensifying problems with our environment should be understood as a contributing factor: ${ }^{8}$

So today, after a little more than two centuries, we find ourselves in the unprecedented situation of having unleashed a new Messianic time, but negative, with a possible apocalypse on the horizon that we have done everything to, at least, delay, divert, and, if possible, avoid. This proposition comes down to rubbing so-called modern history up the wrong way, rewriting it through and through (Hartog, 2016, p. 177). ${ }^{9}$

The two dimensions are not necessarily mutually exclusive; rather, they could be understood as strengthening one another. For example, as some researchers have pointed out, it could be argued that the expansion of a predominantly consumer-oriented form of capitalism, with the geographical extension of the logics of commodities referred to as globalisation, has contributed substantially to further enmeshing humankind's interaction in the earth's geological changes, and by implication enhancing the outlook of the future as a threat. As such, the new regime stands in stark contrast to the promise that it represented in the heyday of the future-oriented regime. ${ }^{10}$

A third line of argumentation, which is discernible in particular in the thought of the German sociologist Hartmut Rosa, is the idea of acceleration. According to this interpretation, the ever-narrower time horizons within which society is envisioned and people act in society is a result of the demands of an ever-faster pace within a number of spheres in society; in this

8 A line of argumentation that ties in with the increasing number of studies focusing on the Anthropocene as a category with which we might reconstruct the past in a way that virtually inverts the progressivist paradigm of the last 200 years or so.

9 "Si bien qu'aujourd'hui, après un peu plus de deux siècles, nous nous trouvons dans la situation inédite d'avoir enclenché un nouveau temps messianique, mais négatif, avec à l'horizon une apocalypse possible qu'il faut tout faire pour, au moins, retarder, détourner et, si possible, empêcher. Cette proposition revient à prendre toute l'histoire dite moderne à rebrousse-poil, en la récrivant de fond en comble." This aspect is also highlighted by the literary theorist Hans Ulrich Gumbrecht (Gumbrecht, 2014, p. viii).

10 For a further discussion of how the geographical expansion has broadened out concurrently with the rise of a consumer-oriented phase (as well as how these changes can be interlaced with other crucial societal phenomena), see: Jameson, 1984; Jameson, 1992; Jameson, 2009; Harvey, 1990; Milbank, 2010; Milbank, 2012; Milbank and Pabst, 2016. 


\section{APPENDIX IV}

sense, the presentist regime of historicity could be seen as the upshot of an acceleration of the future-oriented regime (Rosa, 2009). Clearly, the idea of social acceleration does not exclude the other two arguments.

However, in addition to these extra-educational, structural changes, there is a further, more immediately political transmutation that has contributed to this temporal contraction. ${ }^{11}$ Previous research has highlighted how, in the specific case of Sweden, educational reforms throughout the post-war period have brought about a narrowing of the past and the future as structuring time horizons to the benefit of the present (Colla, 2017; Wedin, 2017a; Wedin, 2017b). ${ }^{12}$ Under the aegis of emancipation, the focus successively shifted away from teachers and a canon bound to tradition, which throughout the post-war period increasingly came to be seen as inhibiting the education of free democratic subjects, and towards individual pupils and the present. As the Italian historian and sociologist Piero Colla writes in his voluminous and rich study of the post-war Swedish educational system, this should be understood in light of the reference:

[...] to the necessity of objectivity in order to counter all forms of sentimental indulgence towards a rhetorical tradition with its hierarchies so typical of the school world; crisis of legitimation in the name of social utility for all teaching in humanities, of all demands of culture for the sake of culture, and finally of the practice of transmission as such (Colla, 2017, p. 862). ${ }^{13}$

As I have argued elsewhere, this move towards the present can be understood, in part, as the result of a specific individualist-inducing form of equality (Wedin, 2017a; Wedin, 2017b; Wedin, 2018a).

In the following section, I will build on my previous findings by exploring how the specific form of imaginary equality is distinct from other influential forms of equality. I will attempt to establish in what sense it could be understood as an impulse that contributed to the political landscape that took shape during the post-war period (and which remains a relevant structuring ideal in contemporary political life).

11 More immediate in the sense of being a more directly political ideal that has added to our presentist condition. That said, I do not thereby mean that the economic and/or environmental changes would not also - ultimately - be of a political character.

12 Cf. also Marcel Gauchet's analysis of the French educational system (Gauchet, 2002; Gauchet, 2017), and Pomian, (2013).

13 “' [...] au devoir d'objectivité pour contrer toute indulgence sentimentale envers une tradition rhétorique et les hiérarchies propres à l'univers scolaire; crise de légitimité, au nom de l'utilité sociale, de tous les enseignements humanistes, de toute revendication de la culture pour la culture, et finalement de la pratique de la transmission en tant que telle." 


\section{Equality}

We find an early definition of this new form of equality in Alexis de Tocqueville's thought. In De la démocratie en Amérique [part 1: 1835; part 2: 1840], he suggests that a new form of equality seems to go hand in hand with the rapidly changing society. It is a form of imaginary equality, strong enough to counter the "wealth and poverty, command and obedience [that] accidentally put great distances between two men”, since:

[...] public opinion, which is based on the ordinary order of things, brings them closer to the common level and creates between them a kind of imaginary [imaginaire] equality, in spite of the real inequality of their conditions (Tocqueville, 1981, p. 226). ${ }^{14}$

This impulse of equality neither speaks the language of material interests, nor aims at political equality; it is a societal force asserting the conviction that everyone has the right to be seen and accepted for what they are. In the same vein, Arendt writes:

Much more is involved in this than equality before the law, more too than the levelling of class distinctions, more even than what is expressed in the phrase "equality of opportunity" [...] (Arendt, 2006a, p. 176)..$^{15}$

For Tocqueville, this was a slow transformation in how we approach one another in what we call the modern world; a force that spawned both new possibilities and dangers. In his reflections on the new society that was taking form among the revolutionary brethren on the other side of the Atlantic, Tocqueville observes:

Regarding the influence that one man's intelligence can have over another man, it is necessarily strongly limited in a country where the citizens have become more or less equals and look at each other closely. Since they do not in any of the others see any sign of grandeur or incontestable superiority,

14. "l'opinion publique, qui se fonde sur l'ordre ordinaire des choses, les rapproche du commun niveau et crée entre eux une sorte d'égalité imaginaire, en dépit de l'inégalité réelle de leurs conditions".

15 Arendt's debt to Tocqueville is also expressed in On Revolution, where she writes that "equality, which we, following Tocqueville's insights, frequently see as a danger to freedom, was originally almost identical with it" (Arendt, 2006b: 20). Arendt further argues that it seems reasonable to understand this development as a continuation of the disappearance of the authority of the political sphere in the pre-political sphere (Arendt, 2006a, p. 190), and as a continuation of the emancipation of workers and women (Arendt, 2006a, p. 184). The specific educational "crisis" to which Arendt refers should be read in light of the shock wave caused in the USA by the successful launching of Sputnik by the Soviet Union in 1957, where in particular the insufficiency of the educational system was pointed out as an explanation of their relative backwardness. 


\section{APPENDIX IV}

they all tend towards their own reason as the most visible and closest to the truth (Tocqueville, 1981, p. 10). ${ }^{16}$

Tending towards an increased equality between individuals, the latter tend to rely less and less on others (some source of explicit authority) and instead consider themselves to be the most reliable source of judgement. As such, it is a form of equality that fosters individualism (Gauchet, 2005; Dumont, 1992; Manent, 2012; Manent, 2007). ${ }^{17}$

A fruitful way to further develop our understanding of this form of equality is to juxtapose it with the two forms of equality that are traditionally contrasted: formal equality and distributive equality. The formal concept of equality is critically described in Marx's On the Jewish Question, where he notes that:

The state in its own way abolishes distinctions based on birth, rank, education and occupation when it declares birth, rank, education and occupation to be non-political distinctions [...] Nevertheless the state allows private property, education and occupation to act and assert their particular nature in their own way $[\ldots]$ Far from abolishing these factual distinctions, the state presupposes them in order to exist (Marx, 1975, p. 219).

From this brief quote, we can discern two contrasting, but arguably interrelated, ideals of equality. First we find the formal ideal of equality in the bourgeois state that spread throughout Europe in the $19^{\text {th }}$ century: each subject is considered an equal before the law, in a society based on merit rather than precedence. Yet, however much of an improvement this was seen to be on the part of the labour movement, it was assumed to obscure the distributive inequalities on which the formal equality of bourgeois society was constructed. Real equality thus presupposes, argued Marx, the annihilation of the dominant economic system, and its replacement of an order founded on a materially grounded idea of equality. Thus, alongside the imaginary form of equality, we can now add the formal and distributive forms of equality..$^{18}$ Now, few would contest the mobilising force contained within the formal and real conceptions of equality. But what explanatory force lay in the imaginary form of equality?

16 “Quant à l'action que peut avoir l'intelligence d'un homme sur celle d'un autre, elle est nécessairement fort restreinte dans un pays où les citoyens, devenus à peu près pareils, se voient tous de fort près, et, n'apercevant dans aucun d'entre eux les signes d'une grandeur et d'une supériorité incontestables, sont sans cesse ramenés vers leur propre raison comme vers la source la plus visible et la plus proche de la vérité."

17 For the educational system in particular, see: Gauchet, 2002; Statius, 2009; Wedin 2018a.

18 Furthermore, it should be added that here I am discerning ideal types. Hence, I do not preclude other possible ideals of equality, for instance, in Marx's thought. 


\section{Imaginary Equality as a Political}

One illustrative way of elucidating how imaginary equality as an analytical construct can contribute to a furthering of our understanding of the postwar political landscape is to turn to the educational sphere. Building on what I have argued elsewhere, the radicalised progressivist-inspired way to envisage the individual pupil in school in the late 1960 s and onwards, up until the wave of reforms starting in the municipalisation in 1989, helped to pave the way for the purported "neoliberal" reforms of the 1990s (Wedin, 2017a; Wedin, 2017b). In the first decades, the ideal of centring the pupil was made via allusions to the importance of furthering the democratic project by vindicating the right of the individual pupil to - under democratic forms - integrate in society; and all of this without having to be subject to the restraints of tradition. But while one of the central tasks of the teacher through to the 1970 s was to transmit a heritage, and as such to implicitly convey a collective emotional attachment to an imagined/constructed shared culture, since that time the emotional centre of gravity has increasingly been reoriented towards the individual pupil in the present, as the teachers were requested to emphasise the individual and to focus on the here and now (Colla, 2017; Landahl, 2015; Wedin, 2017a; Wedin, 2017b; Widhe, 2016, p. 90). ${ }^{19}$ As Colla puts it, we seem to be confronted with an ideal in which:

[...] the dialectical adversary is, on each occasion, the inert force of habit, which separates in secrecy, where it is about to assemble by unveiling (Colla, 2017 , p. $853 f.)^{20}$

In contrast to this post-war discourse of democratisation, the reforms around 1990, in particular the introduction of a voucher-system in 1992, have often been depicted as an instance of neoliberalisation, or as a system change of educational policies (Jarl \& Rönnberg, 2011, p. 56; Ringarp, 2011; Schüllerqvist, 1995; Wahlström, 2009, p. 82f.). ${ }^{21}$ However, with regard to the emphasis on the individual and the associated downplaying of transmitting content, as well as the tendency to focus strictly on the present, the motivation here is to emphasise continuity, more so than before.

From this limited but historically and politically significant perspective, it is of less significance that the policy reforms around 1990 are often

19 Regarding this shift towards an increasingly individual-centred emotional order, see: (Karlsohn, 2015; Wedin, 2018c).

20 “ $[\mathrm{L}]$ 'adversaire dialectique est, à chaque reprise, la force inerte de l'habitude, qui sépare dans le secret, là où il s'agit de réunir en dévoilant”.

21 For an illuminating account of the various liberal traditions to which these reforms could be related, see: Fernandez, 2012. 
depicted as a rupture with what has been called a "collectivist model" of democracy, and a move towards an "individualist model" of democracy. In order to understand these manifest changes, one must reflect on the role of imaginary equality as an ideological force. ${ }^{22}$ As I will show in the following section, it is indicative of an inherent paradox within the modern project, which has origins that extend well beyond the recent "neoliberalisation" of the 1990s. As such, in contrast to existing research, the imaginary equality is closely intertwined with the democratisation of the educational system.

In light of this, in order to grasp the dynamics of the wave of reforms around 1990, neither the formal nor the distributive economic equality provides sufficient guidance: we need a more supple concept. ${ }^{23}$ As I have argued elsewhere, Tocqueville's conception of equality is not only able to render the dynamic behind these changes more comprehensible; it also points to a paradox at the very heart of the democratic project itself (Gauchet, 2002; Wedin, 2017b; Wedin, 2018b). The gist of the paradox is that this specific form of equality seems to induce forces that serve to dilute the very political ideal - namely democracy - that gave rise to the demand for equality in the first place. In what follows, I will examine the dynamics of this paradox by drawing on Gauchet's illuminating reflections on the theme.

\section{The Paradox of Democratic Equality}

With the French philosopher Marcel Gauchet, we could think of this as a transformation from a pattern of interactions structured by a collectively rooted order, where the individual is interpellated against the backdrop of school's specific role as an essentially mediating institution (between the individual and the world), to the expansion of one where the individual qua right-bearer whose will ought to be protected (Gauchet, 2017, p. 557f.). Another way to conceive of this shift might be to think of it as an expansion of the private sphere into the educational system, which previously had been considered a kind of introduction into the public sphere (Wedin, 2017b).

In line with earlier research on the Christian roots of Western individualism, though Gauchet repeatedly stresses that the conception of the indivi-

22 It is ideological in the sense that the equalisation of relations is seen as being undertaken by a democratic force that imposes itself, so to speak, from the outside; it has been imposed as a force that exists beyond the sphere of political decision (Arendt, 2004, p. $606 \mathrm{f})$.

23 How these various forms of equality relate to one another falls beyond the scope of the present article. Suffice it to say that they need not be mutually exclusive, and that it seems much more reasonable to assume that they relate to each other. 
dual and its relative centrality in society has a long historical pedigree, he also notes that it: ${ }^{24}$

[ ...] does not result in a society of individuals, properly speaking, before it finds its consecration in law, by means of the conjunction of concrete individualisation with the abstract individualisation, which erects the individual as the unique and exclusive centre of all legitimacy in the public sphere (Gauchet, 2017, p. 554, my italics). ${ }^{25}$

The distinction between a concrete and an abstract individual is crucial: in Gauchet's vocabulary, the surge of human rights, as the leading symbolic form through which political communities are envisioned, brought about a concretisation of individualisation. In contrast to the liberal society that took shape in the $19^{\text {th }}$ century, where the identity of individuals depended on social categories, the concretisation of the individual that has emerged since the 1970 s has brought about a structure in which each and every one understands "themselves as a right" (Gauchet, 2017, p. 558). ${ }^{26}$ And as much as human rights have performed an important counterbalancing role in respect of the relation between the state and the individuals incarnating the state, it is based on the rights of individuals, and as such it cannot serve as a sufficient basis for a constructive and proactive collective action. It is and shall remain limited to legal matters and adjustments regarding the individual (or eventually parallel group rights); as Gauchet notes, the very "engine" of human rights is "entirely negative" (Gauchet, 2017, p. 667). ${ }^{27}$

Besides curtailing the possibilities of political action by emphasising the individual as the point of departure for joint action, human rights as a political compass have also, in their putatively universal guise, severely

24 See, among others: Dumont, 1991 and Siedentop, 2014.

25 "ne débouche sur la société des individus proprement dite que lorsqu'il trouve sa consécration en droit, grâce à la conjonction de l'individualisation concrète et de l'individualisation abstraite qui l'érige en foyer unique et exclusif de toute légitimité dans l'espace collectif'.

26 "[...] de soi comme droit."

27 "Le moteur est tout négatif". Jacques Rancière has - for good reasons - criticised the jeremiads in French political life presented by those who blame our current predicament on the incessant demands of more rights from an insatiable crowd of hedonists who have no sentiments whatsoever for res publica. In his critique, he mentions, among other undercurrents, the inspiration of the "neo-tocquevilliens". I agree entirely with his critique of those who seek to explain our predicament with unqualified moralistic condemnations of the lack of public spirit "among the people". In contrast, my analysis does not draw on some vague "spirit of the times", but instead focuses on how pupils have been interpellated within the educational sphere and how that could be understood as a politico-temporal problem. See: Rancière, 2009. As Michalinos Zembylas correctly cautions against, in order for human rights to avoid being reified into dead letters, and to be capable of engendering critical reflections on the conditions of politics, it is essential that this temporal dimension be duly addressed (Zembylas, 2017, 722). 
undercut the possibilities of rendering explicit a given society's historicity. Indeed, in the name of abstract universalism, it is strongly biased against any form of argumentation based on the particularities of different existing political communities. In virtue of aiming at that which all individuals across the globe are assumed to desire, the conception of the individual that underpins human rights discourse is doomed to remain abstract. Nor does its individualist structure provide any productive political categories through which a given political community could collectively project itself into the future; as such, it goes hand in hand with the condition of presentism outlined above (Gauchet, 1980; Gauchet, 2002; Gauchet, 2017). ${ }^{28}$

There is another aspect of Gauchet's reasoning that I wish to draw attention to before proceeding. The above-sketched interrelated movements are connected to the shift towards what is often referred to as a "neoliberalisation" of public life, thereby tying in with the previously outlined educational reforms around 1990. Gauchet conceives of the neoliberal dispositif as twofold: in line with a number of other theoreticians, he concurs with the regular definition of neoliberal as promoting and imposing an economic vision on public affairs and privileging market solutions on the grounds of economic arguments of efficiency. As much as this aspect of our current state of affairs manifestly captures an essential dimension of the political development since the 1980s, it overlooks one of its crucial ideological sources. The very language of efficiency as such, argues Gauchet, is the result of a society structured around the assumption that what holds it together is people's mutual private interests. The peculiarity of the society that has emerged since the 1970s is that this logic has expanded to all spheres of society. And it is here that we find the essential difference between neoliberalism and classical liberalism: "the neoliberal vision is nothing but the understanding of collective life based on the abstract individual [...]" (Gauchet, 2017, p. 550). ${ }^{29}$

Thus, the tendency towards reification that we commonly associate with the prevalence of neoliberalism should rather be seen as a compound structure corresponding to a society founded on the ideal of the abstract individual (Gauchet, 2017, p. 558). In practical life, where institutions, organisations, etc. continue to exist, this restructuration also permeates

28 The way in which Gauchet outlines the abstract individual coincides in a number of aspects with the young Marx's critique of presuppositions underlying the French declarations of human rights in On the Jewish Question, but one of the foremost advantages in mobilising Gauchet is precisely his reflections on the temporal dimension of political action (and by virtue of this, also the more productive form of political reflection that follows on from this), see: Marx, 1975.

29 “En fait, la vision néolibérale n'est autre chose que la lecture de la vie collective pratique à partir de l'individu abstrait [...]." 
these institutions; whence another scapegoat for our current predicament stems: new public management. For Gauchet, it is in this light - where organisations and individuals are conceived of and interpellated as abstract interest-driven entities - that we ought to comprehend the rise of neoliberalism with its privileging of the market as a solution to public problems (Gauchet, 2017, p. 550f.). ${ }^{30}$

Now, how can we confront these aporias and rethink the challenge of education from a more politically sensible point of view, and thereby exit this seemingly self-refuting logic? As we shall see in the discussion that follows, in which we move from Gauchet's framework and instead turn to Arendt, the temporal dimension is crucial for understanding the difference between the outlined imaginary equality and the political way of envisaging equality set out below.

\section{Educating for Political Equality: a Politico-Temporal Approach}

As a political ideal, the raison d'être of democracy is freedom; freedom in the twofold sense that it aspires to convey both individual freedom, protected by a catalogue of individual rights and freedoms, as well as collective freedom. ${ }^{31}$ One of the basic institutions supposed to support the subsistence and functioning of these ideals is the educational system, in particular preuniversity education. In the previous section, I referred to earlier studies indicating how the manifestly individual-oriented reforms around the $1990 \mathrm{~s}$ have their roots in the post-war period, and how they seem to be related to a specific form of imaginary equality. I will now refine the discussion on equality and our condition of presentism by mobilising Arendt's reflections on the role of education as read in light of her political theory, as well as how her educational reflections reveal aspects of her political theory. I will not draw exclusively on Arendt, but will, as the argumentation unfolds, intersperse the exposition with thoughts from thinkers who have engaged with similar problems in order to further elucidate the argument that I want to make.

30 In Gauchet's conception of history, the outlined changes are in themselves closely related to what he sees as a shift in Western society from the last remnants of a heteronomous order to a structurally - which he carefully distinguishes from a substantially - autonomous order. These even bolder historical philosophical reflections have here been excluded, since the points I wish to make by way of Gauchet's reflections do not depend on these (and clearly, they would have required far more attention than I could possibly give here).

31 For an erudite and thought-provoking attempt to discern how freedom migrated from being the very essence of politics to becoming a question of the inner life of the mind, see Arendt, 2006: Arendt, 1978. 


\section{APPENDIX IV}

In contrast to the three previously presented forms of equality, the idea of equality from which Arendt draws inspiration is the ancient Greek ideal of isonomia, which emerged out of the experiences of public autonomy in Athens during the classical period. ${ }^{32}$ Although its literal meaning is equality in front of the law, its implications, the ideals on which it rests, and the experiences that gave rise to it, mean that any comparison with the formal ideal that emerged during the modern period is rather irrelevant. ${ }^{33}$ The incompatibility, according to Arendt, is difficult for us to understand, since:

$[\ldots]$ we link equality with the concept of justice and not with that of freedom, which is why we misunderstand the Greek term for a free constitution, isonomia, to mean what equality before the law means for us. But isonomia does not mean that all men are equal before the law, or that the law is the same for all, but merely that all have the same claim to political activity [...] (Arendt, 2007, p. 118). ${ }^{34}$

This way of conceiving equality as a political concept can already be discerned in the earlier work The Origins of Totalitarianism (1951), where Arendt questions the claim that we are born equal. Instead, and along similar lines to what we find in Gauchet, she argues that we "become equal as members of a group on the strength of our decision to guarantee ourselves mutually equal rights" (Arendt, 2004, p. 382). ${ }^{35}$

As a starting point for how the political aporia of democratic education could be reconsidered in light of this political ideal of equality, as well as related to the pivotal role that the temporal dimension plays here, let us turn to her reflection in "Crisis in Education":

Because the world is made by mortals it wears out; and because it continuously changes its inhabitants it runs the risk of becoming as mortal as they. To preserve the world against the mortality of its creators and its inhabitants it must be constantly set right anew [...] Our hope always

32 Another, more recent theoretician who has also elaborated on the subject is Nadia Urbinati, see: Urbinati, 2012.

33 Which stems from isos = equal, and nomos = law.

34 Moreover, in On Revolution, Arendt writes: "equality, which we, following Tocqueville's insights, frequently see as a danger to freedom, was originally almost identical with it" (Arendt, 2006b, p. 20).

35 In the same vein, she argues in The Promise of Politics that the idea that there is something "political in man that belongs to his essence [...] simply is not so; man is apolitical. Politics arises between men, and so quite outside of man" (Arendt, 2007, p. 95). And in a similar but stronger formulation, Gauchet, in the concluding pages of the above-mentioned Avenement de la démocratie concerning the ideal of liberty, writes: "man is not born free; he is born in chains - chains that he has created himself in order to support himself in existence. The miracle of our history is that he has been able to release himself from them, in constructing an enormous apparatus without which this emancipation would be but a vain word" (Gauchet, 2017, p. 743). 
hangs on the new which every generation brings; but precisely because we can base our hope only on this, we destroy everything if we so try to control the new that we, the old, can dictate how it will look. Exactly for the sake of what is new and revolutionary in every child, education must be conservative, it must preserve this newness and introduce it as new thing into an old world [...] (Arendt, 2006a, p. 189).

A crucial aspect of Arendt's argumentation is how the educational practice should serve as an intergenerational bridge, where the old is defended from the new, and the new from the old. ${ }^{36}$ This is a peculiarity that renders school as a sphere foundationally distinct from the public sphere, for which it is assumed to prepare the newcomers. Based on Arendt's reflections, it is best thought of as a kind of atrium of the public sphere. ${ }^{37}$ However, as pointed out in the passage cited above, the defence of school as a preparatory institution is also a way of protecting the novelty, the potentiality of giving birth to something new, that each child carries within, and on which the public sphere depends for its survival (Arendt, 2006a, p. 189).

The idea of the public sphere, a "worldly space", stands at the centre of Arendt's political thought (Arendt, 2006a, p. 167). ${ }^{38}$ It is here that our capacity to freedom, to repeat the miracle through which each and every one of us entered the world, can "come out of hiding, as it were, make its appearance" and become political action (Arendt, 2006a, p. 167). ${ }^{39}$ Aside from its concretely physical aspect - serving as something around which we can gather, but which concurrently separates us - Arendt's idea of a public sphere also presumes a space where individuals can transcend their idiosyncrasies and private lives so as to approach the world and all its challenges as political subjects, being able to act beyond the "necessities of life" to act as free beings (Arendt, 2006a, p. 147). ${ }^{40}$ At the bottom of this approach to the challenge of living together, we find a thoroughly political idea of equality; being equal to other citizens here means that one meets

36 It should be stressed that Arendt's own position on this matter is not unequivocal, and the texts from which I draw primarily are The Human Condition and Between Past and Future. In doing so, I abstain from engaging in a discussion of how to reconcile her application of her own theoretical concepts, notably the social, in "Reflections on Little Rock" with what she writes in the former two works.

37 Cf. Bergdahl and Langmann, 2017.

38 Regarding the close ties between the world and education in Arendt's thought, see also: Foray, 2001.

39 Drawing on the passages in the New Testament where "miracles are clearly not supernatural events", Arendt argues that a miracle is the materialisation of the unexpected, an event interrupting "some natural series of events, of some automatic process" (Arendt, 2006, p. 166).

40 Politics and the public sphere is a recurrent theme throughout Arendt's oenvre. The most noteworthy of her work in this area include: Arendt, 2006a; Arendt, 2007. The liaison between these concepts and her way of conceiving of the world is developed in particular in "Promise" and "Human Condition". 


\section{APPENDIX IV}

with one's political equals face-to-face to deliberate and formulate solutions to common problems. ${ }^{41}$

As such, it is an ideal of equality that contrasts starkly not only with imaginary equality, but also with the distributive or "real" ideal of equality, as well as the liberal concept of equality before the law..$^{42}$ Nor does her political thought fit into any of the traditional categories of socialist, liberal, social-democratic, etc. The form of political equality advocated by Arendt, which organises "those who are absolutely different with a view to their relative equality", could thus be considered an attempt to politically overcome the individual-collectivist division so prevalent in modern political thought (Arendt, 2005, p. 96). ${ }^{43}$ Following Margret Canovan, it is a "genuinely political equality" revolving around an idea of unity via difference, serving to create a "space between plural individuals" (Canovan, 1992, p. 243). ${ }^{44}$ It is against this backdrop that we should understand the educational "conservatism" of Arendt, where school serves as a mediating institution between the continuity of the world and protection of the impulses of novelty incarnated in children.

${ }_{41}$ For analyses regarding how this concept of equality relates to various forms of liberty, as well as different competing forms of equality, not least the competing neo-roman republican approach, see: Urbinati, 2012. Arendt returns to the specific form of public judgement and how it is constitutive of political action; see: Arendt, 1992; Arendt, 2003; Arendt, 2007.

42 Along the lines of her ideal of Denken obne Geländer, Arendt answered the question of where she stands politically with regard to the common ideological families in the following way: "I don't know [...] I suppose I never had such a position [...] I must say I couldn't care less. I don't think that the real questions of this century will get any kind of illumination by this kind of thing [...] I never was a socialist [...] I never was a liberal. I never believed in liberalism. When I came to this country I wrote in my very halting English a Kafka article, and they had it 'Englished' for the Partisan Review. And when I came to talk about them about the Englishing I read this article and there, of all things, the word 'progress' appeared! I said: 'What do you mean by this? I never used that word', and so on. And then one of editors went to the other in the next room and left me there and I overheard him say, really in a tone of despair, 'She doesn't even believe in progress"' (Hill, 1979, p. 333f.).

43 In this regard, Arendt's political thought is comparable with the various attempts to revitalise different forms of republican political traditions. Besides the already quoted Urbinati (2012), other influential works include: Skinner, 2012; Pettit, 2010. For an overview of republican traditions, see: Laborde and Maynor, 2008.

44 In the reception of Arendt's political thought, two dimensions are often highlighted in the form of republicanism that she cherished. On the one hand, we find what Passerin d'Entrèves has called her communicative model of action. Benhabib calls this the narrative model of action in her thought. Beside this, she also stresses how public life offers a scene for the citizens to disclose their "who's" in front of their co-citizens. This disclosing potentiality for the individual has been referred to as the expressive aspect of her theory of political action (Passerin d'Entrèves, 1994, p. 84; Benhabib, 1996, p. 125). 
Historically, this challenge to education can be traced back to a problem in the Western tradition of political thought (Arendt, 2006a, p. 187). ${ }^{45}$ The problem, to be more precise, lies in the fact that, historically, political authority, already for Aristotle as well as for Plato, has all too often been confused with the absolute superiority that temporarily characterises the relationship between parents and their children. The absolute superiority, on which the child-adult relationship is based, derives from its temporality: it is absolute precisely because it is temporary (Arendt, 2006a, p. 187). The problem with education, Arendt writes, lies:

$[\ldots]$ in the fact that by its very nature it [the education] cannot forgo either authority or tradition, and yet must proceed in a world that is neither structured by authority nor held together by tradition. That means, however, that not just teachers and educators, but all of us, insofar as we live in one world together with our children and with young people, must take toward them an attitude radically different from the one we take toward one another. We must decisively divorce the realm of education from the others, most of all from the realm of the public, political life, in order to apply to it alone a concept of authority and an attitude toward the past which are appropriate to it but have no general validity and must not claim a general validity in the world of grown-ups (Arendt, 2006a, p. 191-192).

Yet, as Arendt asks, is it possible to envisage a more substantial ideal, an idea of teachers as authorities mediating between past and future, simultaneously charging responsibility for the world and defending the individual child, under circumstances in which tradition and authority are no longer structuring forces (Arendt, 2006a, p. 189ff.)? ?6

In order to answer this question, we first need to make an elementary distinction. We need to distinguish between authority as a socially structuring ideal, and the very social conditions out of which authority as an ideal has emerged in most known societies. Although authority in the first sense has clearly dissipated in late modern Western societies, with Sweden

45 As a consequence of the rupture with the tradition that the reformation implied, which brought with it a more fundamental trembling of our way of relating to the past, and later the questioning of the secularisation in the $18^{\text {th }}$ and $19^{\text {th }}$ century, it was but a question of time before the third pillar, authority, would also crumble. It should therefore not, Arendt reminds us, come as a major surprise that it was in the USA, where the political authority was first undermined, that the problems first appeared in the 1950s (Arendt, 2006a, p. 187f.).

46 As she puts it "Crisis in Education": "Education is the point at which we decide whether we love the world enough to assume responsibility for it and by the same token save it from that ruin which, except for renewal, except for the coming of the new and young, would be inevitable. And education, too, is where we decide whether we love our children enough not to expel them from our world and leave them to their own devices, nor to strike from their hands their chance of undertaking something new, something unforeseen by us, but to prepare them in advance for the task of renewing a common world" (Arendt, 2006a, p. 193). 
excelling (although the appropriateness of this verb is disputable), it is less obvious that the social conditions from which it historically arose have also vanished. In Conditions de l'éducation, the philosopher Marie-Claire Blais, the educational philosopher Dominique Ottawi and the already mentioned Gauchet, present five fundamental human conditions that inevitably generate some form of authority.

Authority is first of all closely related to legitimacy. The human-social sphere is unimaginable without a normative dimension, with which we ought to understand that human societies do not merely exist, but that "they make themselves, define themselves, they choose themselves by refusing and prescribing [...] they justify these choices" (Blais et al., 2002, p. 150).47 A second condition is rooted in the fact that human societies function through belief, and cannot function in any other way; the self-defining voluntarism emphasised by proto-liberal and bona fide liberal thinkers alike also stipulates various foundational beliefs. As the theologian John Milbank writes, the notion of an abstract individual is:

[...] not really metaphysically neutral insofar as the reverse face of an affirmed subjectivity as to value is always objectivity as to fact and procedure. For this reason, the liberal procedural formalism that is supposed to safeguard the sanctity of private freedom tends to collapse in favour of the rule of the material $[\ldots]$ (Milbank, 2016, p. 248). ${ }^{48}$

We are doomed to believe in a multiplicity of persons around us, and with few exceptions on an everyday basis. Thirdly, authority exists because we are embedded in relations with others. The social landscape impresses upon us through the language with which we are interwoven before we exist as independent entities, and transmits a culture, as well as those constitutive ideas with which it is nourished. This is a condition that structures our everyday lives with or without a manifest authority.

A fourth reason behind the existence of authority relates to how we function interdependently vis-à-vis those concrete individuals surrounding us. In comparison with the third reason, where authority is thought to structure the individual via her appropriation of a language, the emphasis here is on our orientation toward identification with the other. The human individual is a being for "whom the process of a psychic constitution gravitates around identification" (Blais et al., 2002, p. 153). ${ }^{49}$

47 "elles se font, elles se définissent, elles se choisissent par des refus et des prescriptions [...] elles justifient ces choix"

48 For an analysis in a similar vein regarding the effects of this for the formation of elites in Great Britain, see: McCulloch, 1991.

49 “[...] dont le processus de constitution psychique gravite autour de l'identification". As seen in all three examples - the second, third, and fourth reason - a characteristic trait is that 
Fifth and finally, authority is a necessary condition for freedom: in order for the latter to exist, there must be external points of reference to which the individual can relate; our freedom is identified and affirmed in our relation to the potential limits imposed by those external points, which we refer to and construe as authorities. We would not be able to act in situations where ideals and values come into conflict without implicitly postulating an ideal authority in relation to which we can arrange our thoughts. And this is so even when those idealised points of reference "merely" affect us in a negative way - that is, in order to be negated.

Now, there are certain sets of assumptions within the arguments of Blais et al., ranging from less to more controversial. But for our purposes here, we need not accept them all. I do, however, maintain that their argumentation is sufficiently convincing insofar as they support Arendt's claim that we cannot do without the phenomenon that some exercise influence over others, and that this is a crucial dimension of intergenerational relations. Moreover, this is the case regardless of whether it is acknowledged or not: that is to say, it is a transhistorical phenomenon. ${ }^{50}$ This is why I contend that we ought to take Arendt's qualified conception of authority seriously.

In order to further elaborate on this claim, a relatively elementary, but essential, distinction made by Castoriadis regarding power will serve as a useful illustration: namely his distinction between "explicit power" and "infra-power" (Castoriadis, 2000, p. 134). Explicit power, as implied by the wording, corresponds to the various explicit forms of power, such as the monopoly of violence, the legal system, and the educational system in a community. Infra-power, on the other hand, covers all forms of power that is exercised beyond the formalised institutions of power: "Language, family, manners, 'ideas', and an innumerable multitude of other things and their evolution fall essentially outside the confines of jurisdiction" (Castoriadis, 2000, p. 134). ${ }^{51}$ From this it follows that the narrowing of official institutions nowhere implies that individuals' independence increases with the decline of the influence exercised by formal institutions: our historicity can be denied, but it will not disappear. We will continue to always already act within inherited patterns - irrespective of which generational attitude we

none of them is inscribed in a strictly rational order, but rather operates on various degrees of a non-reflexive and immediate order. Althusser encapsulates this logic neatly with his idea of interpellation, where he - rightly, in my view - argues that the hailing and structure in which the hailing is inscribed are inseparable phenomena (Althusser, 2008, p. 49).

50 With regard to this dimension, see e.g.: Lübbe, 2009; Rüsen, 2012.

51 "La langue, la famille, les moeurs, les «idées » une foule innombrable d'autre choses et leur évolution échappent pour l'essentiel à la legislation”. 


\section{APPENDIX IV}

happen to take towards this. ${ }^{52} \mathrm{We}$ are all immersed in a number of contexts and traversed by multiple influences in a range of ways, but the degree to which various individuals are capable of reflexively relating to these undercurrents varies with their circumstances.

Thus, when the influence of the explicit power diminishes, the importance of the infra-power increases. In virtue of explicating the plethora of undercurrents of which the infra-power is constituted, the formal institutions therefore have a crucial role in undergirding the conditions for reflexivity, for the exercise of private and public freedom (Castoriadis, 2000, p. 151f). ${ }^{53}$ As the American political philosopher Gerald Dworkin notes, it:

$[\ldots]$ looks, then, as if we can only distinguish between institutions on the basis of what they convey, their content, and not on the basis that they influence people at a stage when they cannot be critical about such matters (Dworkin, 1988, p. 11).

In all of these examples, from Blais, Gauchet and Ottavi, via Castoriadis and Dworkin, the temporal dimension is crucial, and in particular the role institutions play in conditioning our temporal orientations. Using these reflections on the role of institutions as a politico-temporal problem as a framework, in what follows I will elaborate on how I believe that Arendt's idea of education as an introduction to the world entails a temporally more coherent way of envisaging equality.

Arendt's idea of the world further develops her dialogue with Martin Heidegger. ${ }^{54}$ However, in contrast to her previous teacher, she does not "emphasize authentic existence in opposition to the masses or das Man" (Kattago, 2014, p. 57). Instead, she forges a political conception of the world, according to which "Men, not Man live on the earth and inhabit the world" (Arendt, 1998, p. 7). This is also evident in the fact that the alienation that concerns Arendt is chiefly an alienation from the world, not from man in his individuality. As a consequence, the remedy is to reconstruct a public sphere through which the individual can partake "in a shared world" with others (Kattago, 2014, p. 57).55 Spatially, the world is thus defined as the "human

52 Comparable to what the German historiographer Jörn Rüsen refers to as "dormant traditions" (Rüsen, 2012, p. 59).

53 The idea of rendering the infra-power more explicit is one of the central aims in Castoriadis' project on autonomy.

54 For a more extensive account of the concept of the world in Arendt's thought, see: Kattago, 2014.

55 In his interpretation of Arendt's idea of world alienation, the political theorist George Kateb writes: "The fact is that Arendt defines the core of world alienation as, precisely, the loss of group differentiation, which is not only the loss of mediation between the individual self and everything else, but the loss of elements that help to compose a self and sanely enlist its energies" (Kateb, 1984, p. 159). 
artifice", which provides men with a physical home "fit for action and speech" (Arendt, 1998, p. 173). Essentially, to live together in a world means that the citizens share a number of things, for just as "a table is located between those who sit around it; the world, like every in-between, relates and separates men at the same time" (Arendt, 1998, p. 52).

In educational terms, the teacher's task is thus to present the artefacts, conventions, laws, and limits of which the world is constituted. It is, as such, a responsibility that will take various forms depending on the subject taught, but the gravity of the teacher's task cannot be overemphasised:56

The teacher's qualification consists in knowing the world and being able to instruct others about it, but his authority rests on his assumption of responsibility. Vis-à-vis the child it is as though he were a representative of all adult inhabitants, pointing out the details and saying to the child: This is our world $[\ldots]$ Anyone who refuses to assume joint responsibility for the world should not have children and must not be allowed to take part in educating them (Arendt, 2006a, p. 186).

That said, in light of the crucial role that the temporal dimension plays in her idea of the world, it would be a mistake to infer from this that the content should be handed down as if out of time. Indeed, the very premise on which her idea of a world is founded is, by definition, that which temporally transcends the individual:

[...] the existence of a public realm and the world's subsequent transformation into a community of things which gathers men together and relates them to each other depends entirely on permanence. If the world is to contain a public space, it cannot be erected for one generation and planned for the living only; it must transcend the life-span of mortal men (Arendt, 1998 , p. 55).

By implication, the world needs to be protected, and in this protection institutions - and in particular school - play a pivotal role. With regard to the educational system, this protection manifests itself in two intimately entangled ways. The world needs (i) protection from the incessant stream of newcomers who need to be accustomed to the worldly, institution-structured order. But at the other end of the formation, where the individual pupil approaches the end of her education, the (ii) very continuance of the

56 With regard to the role of responsibility in Arendt's thought, the political thinker and Arendt's French translator, Carole Widmaier, argues that "political life is first and foremost responsibility: it presupposes a burden to carry, an onus which is far from being specific to our modern epoch: it is that [onus] of writing us into humanity - man understood as different from an individual and species - in her proper temporality" (Widmaier, 2012, p. 68, my translation). .56 
world hinges on a never-ending stream of new citizens to provide it with new perspectives. As Arendt writes, it is a permanent task to try to "preserve the world against the mortality of its creators and inhabitants" (Arendt, 2006a, p. 189)..$^{57}$

In this light, teachers must transmit the content in a way that renders the pupils sensible and sensitive to the specific temporal order on which the world depends. In other words, the content transmitted must not be presented as something frozen and detached from our present, as if the purpose were for the "dead to bury the living" (Nietzsche, 2005, p. 95). ${ }^{58}$ Rather, content should be transmitted as incorporating the dynamic realities as they are, and of which the world is constituted. Much like the reification in artworks is "more than mere transformation; it is transfiguration", the introduction to the old world by teachers must aim to instil a sensibility to the specific temporal order on which the world hinges (Arendt, 1998, p. 168)..$^{59}$ To this end, education ought to transcend the transmission of a given content.

Therefore, serving as a mediator between the old and the new, where the newcomers are introduced to the temporally extended public sphere, the practice of education, from an Arendtian perspective, could be described as an attuning of the pupils to a qualitative relation to time, pointing beyond the quantitative stream of time conveyed by the concept of chronos (Sipiora, 2002; Smith, 1969). In virtue of being an artificial form that breaks up the circular temporal order of the life-process, the very idea of the world in Arendt's thought is in itself embedded in a stretched out qualitative temporal order, pointing beyond the confines of the coming and going of separate individuals. "[T] he common world", as Arendt puts it, "is what we enter when we are born and what we leave behind when we die. It transcends our life-span into past and future alike" (Arendt, 1998, p. 55). With regard to the world, it is therefore essential that the educational system inculcates a sensibility among the pupils to the politico-historical order on which the world depends.

A second temporal aspect ensuing from Arendt's reflections on the relationship between the world and education pertains to the close ties between time and action. The educators must therefore strive to inculcate a

57 Where the inverse also holds good, in the sense that children must be protected from the world. Education in this sense means to "cherish and protect something - the child against the world, the world against the child, the new against the old, the old against the new" (Arendt, 2006a, p. 188).

58 "döda begrava de levande".

59 How this transcendent element of artworks bridges the roles of homo faber and the political sphere is also discussed in: Buhre, 2015b. Foray also stresses the close links between the world, Arendt's reflections on culture, and education. See: Foray, 2001. 
practical reason among future participants, with the help of which they can entertain the world when their time comes. Education ought therefore also to attune the pupils to a form of kairological sensibility: a receptivity for the right time in which to act. 60

Rendering the pupils sensible to a qualitative temporality therefore entails (i) making them aware of the politico-historical order of the world, and (ii) instilling a degree of susceptibility for what we might think of as a form of political tactfulness, that is, to attune them to a sensibility for kairos. These are two ways in which Arendt's reflections on education as an introduction to the world point beyond chronos, and extend towards more qualitative forms of envisioning time. ${ }^{61}$

Tackling the educational system on these lines, to concretise, would be one way of engendering the political community at hand with a greater degree of freedom by situating the current state of affairs within history, thereby serving as a protection of the world. But also, by implication, to expand our understanding of the alterability of the current situation. ${ }^{62}$ This is how I conceive of the temporal sensibility in Arendt's reflections on the problem of education in the modern world in light of her political ideals; an ideal of education that serves as a strategy for protecting the spatiotemporal phenomenon that Arendt refers to as the world, and thereby the sphere in which human beings can meet as equals.

However, and as emphasised previously, this must not be understood in a strong communitarian sense, where the individual is supposed to be

60 In John E. Smith's seminal article on the difference between the two, he writes that we "know that all the English expressions 'a time to' are translations of the term 'kairos' - the right or opportune time to do something often called 'right timing"'. This aspect of time is to be distinguished from chronos which means the uniform time of the cosmic system, the time which, in Newton's phrase, aequabiliter fluit. In chronos we have the fundamental conception of time as measure, the quantity of duration, the length of periodicity, the age of an object or artefact and the rate of acceleration of bodies whether on the surface of the earth or in the firmament above" (Smith, 1969, p. 4). For a further discussion of the temporal dimension in Arendt's political thought, see: Braun, 2007; Buhre, 2015a; Buhre, 2015b; Wedin, 2018b. The temporal dimension is also stressed by Maurizio Passerin d'Entrèves, who, in his analysis of Arendt's political thought, refers to the crucial roles that the capacity to hold promises (forward-looking) and that of being able to forgive (backward-looking) play in her thought (Passerin d'Entrèves, 1994, p. 82).

61 This does not, however, entail any form of absolute or essentialised distinction between chronos and the more qualitative forms of orienting temporally. On the contrary, it is essential that teachers are able to dispose the pupils to relate the qualitative orders to the undeniable stream of time, with all its implications, to which chronos refers (cf. Smith, 1969; Frost Benedict, 2002).

62 This way of conceiving of the role of teachers resonates with both Benhabib and the Swedish philosopher Frida Buhre, who have in various ways highlighted the intimate associations between the practice of bomo faber and bios politikos, between work and action, in Arendt's thought (Buhre, 2015b, p. 218ff; Benhabib, 1994, p. 108). 


\section{APPENDIX IV}

subsumed under the collective order. Rather, I take it to be the expression of an attempt to protect the very conditions, i.e. the world, through which Arendt argues that politics - the practice of freedom, where individuals, in spite of their differences, come together and deliberate shared problems as equals - is exercised. It is out of this politico-temporal perspective that the Arendtian conception of equality opens up space for more productive ways to understand what equality might mean as a political ideal in educational terms (in contrast to the other forms of equality discussed in the first part of the article).

As indicated above, in the section on the "paradox of democratic equality", a vexing problem for the imaginary ideal of equality, as well as the abstract ideal of the individual with which it is entwined, is that the very collective forms from which the relative independence of the individual stems - and which this imaginary ideal ultimately nourishes - are sapped. By negating, in the name of emancipation, the cultural landscape of which the world consists, it is also a denial of the temporal orders in which we exist, and through which any form of political freedom must take shape. ${ }^{63}$

In my view, this is the background against which we should understand Arendt's insistence on envisioning the teacher as an authority; an authority in virtue of representing the institutional framework through which our democratic ideal is mediated. Just as the original Latin meaning of auctoritas, in contrast to mere power (potestas), was assumed to grow from its roots in the past, its ancientness, so the idea of authority in educational terms should be envisaged as a temporally conditioned concept; temporal in the doubleedged and intrinsically intertwined sense of serving as that which increases (from Latins augere) the spatio-temporal horizon, and the fact that this heavy responsibility stems precisely from its temporariness (compare p. $15 f$. above.).

\section{Conclusion}

In the opening section of this article, I briefly noted how three overarching societal changes - environmental changes, the transmutations of the capitalist economy, and the phenomenon of acceleration - have contributed to the emergence of a presentist regime of historicity. In addition to these more commonly evoked causes, I showed how previous studies also indicate that a

63 As has been highlighted by many researchers, the distinction between the negating moment of liberation and the practice of freedom is crucial in Arendt's political thought. The dialectics between liberation on the one hand, and the practice of freedom on the other, is a key issue in On Revolution (Arendt, 2006b). The tension between the two in Arendt's thought is discussed at greater length in: Buckler, 2011; Canovan, 1992, p. 211ff; Hansen, 2007, p. 172ff; Bernstein, 2018, p. 118f; Wedin, 2018b; Wedin \& Wilén, 2018. 
specific form of equality has contributed to this new way of orienting in time; an equality that I, drawing on Tocqueville, have referred to as imaginary equality. Beside the transmutations of the capitalist economy, the environmental changes, and the increased acceleration, I maintain that the imaginary equality should be considered as a more directly politically inspired impulse behind the emergence of the present as the dominant temporal horizon. It is an impulse rooted in the ideologically motivated desire to further democratise society by emancipating the individual from the assumed shackles holding her back within the educational sphere. Having noted the political dead-ends that this form of equality as a democratic ideal seems to encounter, I then explored how Arendt's reflections on the role of the educational system offer an outline of a contrasting political ideal of equality, one structured by different temporal logics.

In this context, it could be argued that while any admonishment of the school of the "good old days" might prove futile, equally dangerous is a:

[...] simple, unreflective perseverance, whether it be pressing forward in the crisis or adhering to the routine that blandly believes the crisis will not engulf its particular sphere of life, can only, because it surrenders to the course of time, lead to ruin; it can only, to be more precise, increase that estrangement from the world by which we are threatened on all sides (Arendt, 2006a, p. 191).

It is in this light that I maintain we should read Arendt's claim that a crisis "becomes a disaster only when we respond to it with preformed judgements, that is, with prejudices" (Arendt, 2006a, p. 171). ${ }^{64}$ And it is precisely by tackling the question of education as a politico-temporal problem, with the relationship between world and newcomers as structuring poles, that Arendt is able to go beyond reified dichotomies such as traditionalism and progressivism, and the formation of citizens vis-à-vis the transmission of knowledge. ${ }^{65}$ As I have attempted to show, the Arendt-inspired approach set out above can reveal new avenues for grappling with education in a society founded on the idea of equality that effectively elude similar attempts to map it ideologically, and instead try to seize the kairological opportunity presented by our situation.

64 Which thereby ties in with her extensive writings on political judgement and its relation to politics, see e.g.: Arendt 2007; Arendt 1992; Arendt 2006a; Arendt 2003. The concept of "crisis", on which Arendt draws, has its etymological roots in ancient Greek krisis, understood both as a "decisive moment" and the "act of separating"/ "judgement" (from which the etymologically related "critique" also stems).

65 A reflection that should not in any way be taken as favouring the arguments of Liesbet Hooghe, Gary Marks and Carole J. Wilsons over a so-called Green Alternative Libertarian (GAL)-Traditional Authoritarian Nationalist (TAN) scale (Hooghe et al. 2002); what they create is just another form of grid, which arguably has an even weaker analytical force. 



\section{Literature}

Althusser, Louis. (2008) On Ideology (London, Verso).

Arendt, Hannah. (2006a) Between Past and Future (London, Penguin Classics).

Arendt, Hannah. (1998) Human Condition (Chicago, University of Chicago Press).

Arendt, Hannah. (1992) Lectures on Kant's Political Philosophy (Chicago, University of Chicago Press).

Arendt, Hannah. (2006b) On Revolution (London, Penguin Classics).

Arendt, Hannah. (2003) Responsibility and Judgement (New York, Schocken Books).

Arendt, Hannah. (1978) The Life of the Mind (San Diego/New York/London, Harcourt, Inc.).

Arendt, Hannah. (2004) The Origins of Totalitarianism (New York, Schocken Books).

Arendt, Hannah. (2007) The Promise of Politics (New York, Schocken Books).

Bauman, Zygmunt. (2001) Individualized Society (Cambridge, Polity Press).

Beck-Gernsheim, Elisabeth and, Ulrich Beck. (2001) Individualization (London, SAGE).

Benhabib, Seyla. (1996) The Reluctant Modernism of Hannah Arendt (London/New Delhi, SAGE Publications).

Bergdahl, Lovisa and Elisabeth Langmann. (2017) Where are You?' Giving Voice to the Teacher by Reclaiming the Private/Public Distinction, Journal of Philosophy of Education, 51.2, pp. 461--475.

Bernstein, Richard J. (2018) Why Read Hannah Arendt Now? (Cambridge, Polity Press).

Biesta, Gert. (2005) Against Learning. Reclaiming a Language for Education in an Age of Learning, Nordisk Pedagogik, 25.1, pp. 54-66.

Blais, Marie-Claude, Marcel Gauchet, and Dominique Ottavi. (2010) Conditions de l'éducation (Paris, Pluriel).

Bonneuil, Christophe, Jean-Baptiste Fressoz. (2013) L'Evènement Anthopocène, la Terre, l'histoire et nous (Paris, Seuil).

Braun, Kathrin. (2007) Biopolitics and Temporality in Arendt and Foucault, Time छ' Society, 16.1, pp. 5-23.

Buckler, Steve. (2011) Hannah Arendt and Political Theory: Challenging the Tradition (Edinburgh, Edinburgh University Press).

Buhre, Frida. (2015b) Hannah Arendt och framtidens dilemma, Fronesis, 52-53, pp. 210-220.

Buhre, Frida. (2015a) Speaking the Anachronisms: Arendt, Politics, Temporality (Uppsala, University of Uppsala).

Canovan, Margaret. (1992) Hannah Arendt: A Reinterpretation of Her Political Thought (Cambridge, Cambridge University Press). 


\section{APPENDIX IV}

Castoriadis, Cornelius. (2000) "Pouvoir, politique, autonomie", Le monde morcelé: Les carrefours du labyrinth (Paris: Point Essais).

Castoriadis, Cornelius. (2007) La montée de l'insignifiance (Paris, Point Essais).

Colla, Piero. (2017) L'héritage impossible: conscience historique et technologies de l'identité dans la réforme éducative en Suède 1946-1980(Paris, EHESS).

Danoff, Brian. (2012) A School or a Stage? Tocqueville and Arendt on Politics and Education, Perspectives on Political Science, 41.3, pp. 117-124.

Dumont, Louis. (1991) Essais sur l'individualisme (Paris: Éditions de Seuil).

Dumont, Louis. (1992) Homo hierarchicus (Paris, Gallimard).

Dworkin, Gerald. (1988) The Theory and Practice of Autonomy (Cambridge, Cambridge University Press).

Fernández, Christian. (2012) Liberaliseringen av svensk skolpolitik, Statsvetenskaplig tidskrift, 114.2, pp. 241-269.

Foray, Philippe. (2001) Hannah Arendt, l'éducation et la question du monde, Le Télémaque, 1.19, pp. 79-101.

Frost Benedikt, Amélie. (2002) Doing the Right Thing at the Right Time: Toward and Ethics of Kairos, in Phillip Sipiora and James S. Baumlin (eds.) Rhetoric and Kairos: Essays in History, Theory and Praxis (New York, State University of New York Press).

Gauchet, Marcel. (1980) Les droits de l'homme ne sont pas une politique, Le débat, 3.3, pp. 3-21.

Gauchet, Marcel. (2017) L'avènement de la démocratie: tome iv (Paris, Gallimard).

Gauchet, Marcel. (2005) La condition politique (Paris, Gallimard).

Giota, Joanna. (2013) Individualiserad undervisning i skolan: En forskningsöversikt. Vetenskapsrådets rapportserie 3 (Stockholm, Vetenskapsrådet).

Gumbrecht, Hans Ulrich. (2014) Our Broad Present (New York, Columbia University Press).

Hansen, Phillip. (2007) Hannah Arendt: Politics, History and Citizenship (Cambridge, Polity Press).

Hartog, François. (2016) "Vers une nouvelle condition historique”, Le Débat, 1.188, pp. 169-180.

Hartog, François. (2012) Régimes d'historicité (Paris, Seuil).

Harvey, David. (1991) The Condition of Postmodernity: An Inquiry into the Origins of Cultural Change (Oxford, Wiley-Blackwell).

Hassan, Robert. (2009) Empires of Speed: Time and Acceleration of Politics and Society (Leiden, Brill). 


\section{EDUCATIONAL EQUALITY}

Hill, Melvyn A. (ed.) (1979), Hannah Arendt: The Recovery of the Public World (New York, St. Martin's Press).

Inglehart, Ronald. (1990) Culture Shift in Advanced Industrial Society (Princeton, Princeton University Press).

Jameson, Fredric. (1984) The Politics of Theory: Ideological Positions in the Postmodernism Debate, New German Critique, 33, pp. 53-65.

Jameson, Fredric (1992). Postmodernism, or, The Cultural Logic of Late Capitalism (London/New York: Verso).

Jameson, Fredric. (2009) The Cultural Turn: Selected Writings on the Postmodern 1983-1998 (London, Verso).

Johansson, Alf W. (1995) Herbert Tingsten och det kalla kriget: Antikommunism och liberalism i Dagens Nyheter 1946 (Stockholm, Tiden).

Jordheim, Helge. (2012) Against Periodization, History and Theory, 51, pp. 151-171.

Karlsohn, Thomas. (2016) On Emotion, Knowledge and Educational Institutions, Confero, 4.1, pp. 137-164.

Kateb, George. (1984) Hannah Arendt: Politics, Conscience, Evil (Oxford, Rowman \& Allanheld).

Kattago, Siobhan. (2014) Hannah Arendt on the World, in Patrick Hayden (ed.) Hannah Arendt: Key Concepts (London, Routledge).

Laborde, Cecile and John Maynor. Republicanism and Political Theory, Hoboken, New Jersey NJ: Wiley-Blackwell, 2008.

Landahl, Joakim. (2015) Skolämnen och moralisk fostran: En komparativ studie av samhällskunskap och livskunskap, Nordic Journal of Educational History, 2.2, pp. 27-47.

Lindensjö, Bo and Ulf P. Lundgren. (2014) Utbildningsreformer och politisk styrning (Stockholm, Liber).

Lloyds, Margie. (1995) In Tocqueville’s Shadow: Hannah Arendt’s Liberal Republicanism, The Review of Politics, 57.1, pp. 31-58.

Lübbe, Hermann. (2009) The Contraction of the Present, in Hartmut Rosa and William E. Scheuerman (eds.) High-Speed Society: Social Acceleration, Power and Modernity (Pennsylvania, Pennsylvania University Press).

Manent, Pierre. (2001) Cours familiers de la philosophie politique (Paris, Gallimard).

Manent, Pierre. (2007) Enquête sur la démocratie (Paris, Gallimard).

Manent, Pierre. (2012) Tocqueville et la nature de la démocratie (Paris, Gallimard).

McCulloch, Gary. (1991) Philosophers and Kings: Education for Leadership in Modern England, (Cambridge, Cambridge University Press). 


\section{APPENDIX IV}

Milbank, John and, Adrian Pabst. (2016) The Politics of Virtue (London, Rowman \& Littlefield).

Milbank, John. (2012) Against Human Rights: Liberty in the Western Tradition, Oxford Journal of Law and Religion, 1.1, pp. 203-234.

Milbank, John. (2010) Culture and Justice, Theory, Culture E' Society, 27.6, pp. 107124.

Milbank, John. (2006) Theology and Social Theory: Beyond Secular Reason (Oxford, Wiley \& Blackwell).

Nietzsche, Friedrich. (2005 [1873-76]) Otidsenliga betraktelser (Stockholm, Brutus Östlings förlag).

Passerin d'Entrèves, Maurizio. (1994) The Political Philosophy of Hannah Arendt (London/New York, Routledge).

Pettit, Philip. (2010) Republicanism: A Theory of Freedom and Government (Oxford, Oxford University Press).

Pitkin, Hannah. (1998) The Attack of the Blob: Hannah Arendt's Concept of the Social (Chicago, The University of Chicago Press).

Pomian, Krzysztof. (2013) Partir du présent, Le débat, 175.3, pp. 79-92.

Reinhardt, Mark. (1997) The Art of Being Free (New York, Cornell University Press).

Rosa, Hartmud. (2009) Social Acceleration: Ethical and Political Consequences of a Desynchronized High-speed Society, in Hartmut Rosa and William E. Scheuerman (eds.) High-Speed Society: Social Acceleration, Power and Modernity (Pennsylvania, Pennsylvania University Press).

Rüsen, Jörn. (2012) Tradition: a Principle of Historical Sense-Generation and its Logic and Effect in Historical Culture, History and Theory, 51.6, pp. 45--59.

Sipiora, Phillip. (2002) Introduction: Ancient Concept of Kairos, in Phillip Sipiora and James S. Baumlin (eds.) Rhetoric and Kairos: Essays in History, Theory and Praxis (New York, State University of New York Press).

Skinner, Quentin. (2012) Liberty Before Liberalism (Cambridge, Cambridge University Press).

Smith, John E. (1969) Time, Times and the Right Time, Chronos and Kairos, The Monist, 53.1, pp. 1-13.

Tocqueville, Alexis de. (1981) De la démocratie en Amérique (Paris, Flammarion).

Urbinati, Nadia. (2012) Competing for Liberty: The Republican Critique of Democracy, American Political Science Review, 106.3, pp. 607-621. 


\section{EDUCATIONAL EQUALITY}

Vinterek, Monika. (2006) Individualisering $i$ ett skolsammanhang. Forskning i fokus nr. 31, Myndigheten för skolutveckling (Liber, Kalmar).

Widmaier, Carole (2012) Fin de la philosophie politique (Paris, CNRS éditions).

Wedin, Tomas. (2018c) Education and Emotions: From One Emotional Logic to Another, Conference Proceedings. The Future of Education (Florence, Libreria universitaria).

Wedin, Tomas. (2017a) In Praise of the Present: The Pupil in Centre in Swedish Educational Politics, History of Education, 46.6, pp. 768-787.

Wedin, Tomas. Political Freedom and The Paradoxes of Equality: Three Theoretical Approaches, unpublished paper.

Wedin, Tomas. (2017b) The Democratic Paradox, Confero, 5.1, pp. 193-241.

Wedin, Tomas. (2018a) Tocqueville, Educational Policies and Individualisation: on the democratisation of post-war educational policies in Sweden, Lychnos, pp. 7397.

Wedin, Tomas. (Forthcoming December 2018b) The Aporia of Equality: A HistoricoPolitical Approach to Swedish Educational Politics 1946-2000 (Gothenburg, Göteborgs universitet).

Wedin, Tomas and Carl Wilén. (2018) Equality from Athenian Democracy to the American Revolution: On the Limits of Modern Democracy in Arendt and Meiksins Wood, Distinktion: Journal of Social Theory (under review).

Zembylas, Michalinos. (2017) Re-envisioning Human Rights in the Light of Arendt and Rancière: Towards an Agonistic Account of Human Rights Education, Journal of Philosophy of Education, 51.4, pp. 709-724.

Östling, Johan. (2008) Nazismens sensmoral (Stockholm, Atlantis). 

Appendix V: Reports 

SOU 1935:58, A Report and Proposition Concerning the Obligatory Seven Year Elementary School [Betänkande och förslag angående obligatorisk sjuårig folkskola]

Mixed commission led by the permanent undersecretary of the educational department Nils Teofil Löwbeer, subsequently Director-General for the Patent and Registration Office (1940-54). The rest of the commission consisted of Member of Parliament and Member of the Swedish National Debt Office Gustav Henning Andersson; member of Swedish National Agency for Education [Skolverket] Josef Emanuel Engvall; and the public-school inspector Nils Anton Persson. Research assistant Enar Cyprianus Sahlin was appointed as chief secretary.

SOU 1948:27, Report with Outlines for the Swedish School Development [Betänkande med förslag till riktlinjer för det svenska skolväsendets utveckling]

Mixed commission, headed briefly by Tage Erlander before he replaced Per Albin Hansson as Prime Minister in 1946. The commission was thereafter headed by Erlander's substitute for the post as Educational Minister, Josef Weijne. Under and together with him the commission was constituted of: editor Märta de Laval; professor in Greek at the University of Gothenburg Hans Ingemar Düring; Member of Parliament and medicine licentiate Bertil von Friesen (Folkpartiet); Hilding Gunnar Edvin Albert Färm who by the time served as secretary for Swedish Social Democratic Youth League; Social Democratic politician, director of studies and the public intellectual Alva Myrdal; Member of Parliament Gustav Erik Nilsson (Moderaterna), Member of Parliament and poor relief director Emil Erhard Näsström (Socialdemokratern); director Knut Mauritz Gotthard Olsson; agronomist and Member of Parliament Ivar Persson; Member of Parliament Anna Maria Sjöström-Bengtsson (Socialdemokraterna); and Member Adolf Valentin Wallentheim (Socialdemokraterna). Chief Secretary of the commission was Doctor in literature and Headmaster of State secondary grammar school of Hudiksvall Stellan Arvidsson. The report laid down the broad outlines for what would be the replacement of the so-called parallel school with the comprehensive school in 1962.

SOU 1952:33, The First Teachers Training Education [Den första lärarhögskolan]

Mixed commission led by educational advisor Eskil Källquist. The information in the report is slightly confusing, however: in the end of the report, the professor in classical languages Ingemar Düring is presented 
as chairman. The same inconsequences are repeated in the presentation of the rest of the line-up, where some of the names figuring in the presentation of the researchers behind the report, do not appear in the name list in which all investigators are summed up. Among those that beyond doubt formed part of the committee, we find Stellan Arvidsson as secretary, the secretary for the second chamber Adolf Wallentheim and the lecturer Frits Wigforss. The report constituted the basis for the Government bill of 1954:209.

SOU 1965:29, The Teachers Training: specialist committee regarding teachers training of 1960 [Lärarutbildning. 1960 års lärarutbildningssakkunniga]

Mixed commission headed by Olle Karleby, CEO for the Scandinavian Bank (member of Social Democratic Party). Together with him, we find the Headmaster for the public-school teacher's training seminar Stellan Arvidsson, the Headmaster for the Teacher training college Eskil Källquist, the Headmaster for the Teacher training college in Gothenburg Börje Svensson and Arne Sönnerlind, senior supervisor at the Department for Education. When in 1962 the commission received some additional directives from government, five further experts advices were called in: professor in Quaternary geology Gunnar Hoppe, professor of Education Torsten Husén, member of Skolverket; Bertil Junnel, administrative director for the Swedish Teachers Association Ingrid Linde, and the headmaster for the Teacher training college in Uppsala Ruth Sävhagen. The same year another member of Skolverket, Sixten Marklund, was appointed as expert and primary secretary. Olle Karleby was the son of the key Social Democratic ideologist Nils Karleby (1892-1926). Together with the other reports prepared within the same commission, it formed the basis of the reformed teachers training in Government bill 1967:4.

SOU 1974:53, The Working Environment in School: a consideration by the committee for the inner work of school [Skolans arbetsmiljö: betänkande avgivet av Utredningen om skolans inre arbete (SIA)]

Mixed commission headed by Jonas Orring, Director-General for the Board of Education. Next to him, we find the headmaster Sven-Åke Johansson serving as secretary, the at the time Member of Parliament Britt Mogård (the same who would two years later become Minister of Education for Moderaterna), the secretary Carin Beckius, Member of Parliament Alvar Mårtensson (Socialdemokraterna), Member of Parliament and educational historian Gunnar Richardson (Folkpartiet), Member 
of Parliament Thorsten Larsson (Centerpartiet) as well as the Bachelor candidate Levi Sveningsson.

SOU 1975:9, The Individual and the School SOU 1975:9 [Individen och skolan]

Mixed commission headed by the Director-General of the Board of Education Jonas Orring. Together with him the subsequent persons formed the commission: Member of Parliament Lennart Andersson (Socialdemokraterna); General Manager Sten-Sture Landström; Secretary of state Ulf Larsson; Member of Parliament Jan-Erik Wikström (Folkpartiet). Head of a subdivision in Skolverket Lennart Teveborg.

SOU 1978:86, A Reflection of Teachers Training Committee of 1974: Teacher for a School in development [Betänkande av 1974-års lärarutbildning: Lärare för skola i utveckling]

Mixed commission headed by Secretary of state Anders Arfwedson. The persons serving under Arfwedson in the committee were: Member of Parliament Lennart Andersson (Socialdemokraterna); Member of Parliament Åke Gillström (Socialdemokraterna); Member of Parliament Kerstin Götberg (Centerpartiet); international secretary Urban Karlsson; General Manager Sten-Sture Landström; Member of Parliament Hans Nyhage (Moderaterna); Mrs Maj-Britt Olsson; Director-General at the National Board of Education Lennart Orehag; Bert Stålhammar, school inspector at the National Board of Education. School inspector Stina Nicklasson was appointed as primary secretary. The report served as a foundation for the teachers training reform of 1985, Government bill 1984/85:122, Regarding the teachers training for the comprehensive school etc.

SOU 1985:30, School for Participation: A report of a working group within democracy commission of 1983 [Skola för delaktighet: betänkande från en arbetsgrupp inom 1983 års demokratiberedning]

Mixed commission led by county council commissioner Gunnel Färm. Working together with Färm did: local government commissioner Sven Lindgren; Member of Parliament Larz Johansson (Centerpartiet); local government commissioner Marita Bengtsson; expert [sakkunnig] Johnny Nilsson; the public investigator Mats Ahnlund. As secretary school psychologist Annalill Ekman served (she was also the secretary for the overarching democracy commission. 


\section{SOU 1992:94, School for Bildung [Skola för bildning]}

Specialist commission headed by the General-Director for the National Board of Education (which recently had replaced the previous Board of Education) Ulf P. Lundgren. Next to Lundgren, we find the university assistant teacher [adjunkt] Kerstin Hägg, college teacher Bodil Jönsson, desk officer Barbara Martin Korpi, deputy Director-General Kerstin Mattson (serving under Lundgren in the National Board of Education), the responsible for educational questions at Volvo Rolf Nordanskog, Stig Persson, previous head of department at the Teachers Training College in Stockhom, deputy Director-General Boo Sjögren, and the DirectorGeneral at the National Institute for Disability Issues in schools, Lennart Teveborg. With the change of government later that same year (1991), all commissioners but Lundgren (who remained chairmen) and Sjögren were dismissed, and in came deputy Director-General Kerstin Thoursie and the professor Tor Ragnar Gerholm. As secretaries served, in the first line-up, director of studies Christer Axén, who was replaced by director of studies Berit Hörnqvist in September when the commissioned at large was modified. The report provided the basis for the curriculum of 1994 . 


\section{Dissertations defended at the Department of Literature, History of Ideas, and Religion, University of Gothenburg}

1. Susanne Dodillet: Är sex arbete? Svensk och tysk prostitutionspolitik sedan 1970-talet. (Disp. 21/2 2009).

2. Rangnar Nilsson: God vetenskap - hur forskares vetenskapsuppfattningar uttryckta $i$ sakkunnigutlåtanden förändras i tre skilda discipliner. (Disp. 6/3 2009).

3. Tobias Hägerland: Jesus and the Forgiveness of Sins. An Aspect of His Prophetic Mission. (Disp. 20/3 2009).

4. Per Widén: Från kungligt galleri till nationellt museum. Aktörer, praktik och argument $i$ svensk konstmuseal diskurs ca 1814-1845. (Disp. 28/3 2009).

5. Christian Mehrstam: Textteori för läsforskare. (Disp. 29/5 2009).

6. Christian Lenemark: Sanna lögner. Carina Rydberg, Stig Larsson och författarens medialisering. (Disp. 9/10 2009).

7. Cecilia Pettersson: Märkt av det förflutna? Minnesproblematik och minnesestetik $i$ den svenska 1990-talsromanen. (Disp. 27/11 2009).

8. Ferdinando Sardella: Bkaktisiddhanta Sarasvati. The Context and Significance of a Modern Hindu Personalist. (Disp. 6/2 2010).

9. Kristina Hermansson: Ett rum för sig. Subjektsframställning vid 1900-talets slut: Ninni Holmqvist, Hanne Ørstavik, Jon Fosse, Magnus Dahlström och Kirsten Hammann. (Disp. 20/5 2010).

10. Gunnar Samuelsson: Crucifixion in Antiquity. An Inquiry into the Background of the New Testament Terminology of Crucifixion. (Disp. 21/5 2010).

11. Johan Alfredsson: "Tro mig på min ort" - oöversättligheten som tematiskt komplex i Bengt Emil Johnsons poesi 1973-1982 (Disp. 28/5 2010).

12. Nils Olsson: Konsten att sätta texter $i$ verket. Gertrude Stein, Arne Sand och litteraturens (o)befintliga specificitet. (Disp. 4/6 2010).

13. Erik Alvstad: Reading the Dream Text. A Nexus between Dreams and Texts in the Rabbinic Literature of Late Antiquity. (Disp. 5/6 2010).

14. Georg Walser: Jeremiah: A Translation and Commentary on Jeremiah in Codex Vaticamus. (Disp. 8/6 2010).

15. Marie Fahlén: Jesusbilden i samtiden. Ungdomars receptioner av nio samtida Kristusbilder. (Disp. 23/10 2010).

16. Viktor Aldrin: Prayer in Peasant Communities. Ideals and Practices of Prayer in the Late Medieval Ecclesiastical Province of Uppsala, Sweden. (Disp. 11/11 2010).

17. Stina Otterberg: Klädd i sitt språk. Kritikern Olof Lagercrantz. (Disp. 12/11 2010).

18. Daniel Enstedt: Detta är min kropp. Kristen tro, sexualitet och samlernad. (Disp. 29/1 2011).

19. Michael Tengberg: Samtalets möjligheter. Om litteratursamtal och litteraturreception $i$ skolan. (Disp. 11/3 2011). 
20. Eva Wahlström: Fria flickor före Pippi. Ester Blenda Nordström och Karin Michaëlis: Astrid Lindgrens föregångare. (Disp. 27/5 2011).

21. Rikard Wingård: Att sluta från början. Tidigmodern läsning och folkbokens receptionsestetik. (Disp. 31/5 2011).

22. Andrej Slavik: X. Tre etyder över ett tema av Iannis Xenakis (1922-2011). (1) Avhandling. (2) Exposition, noter, bibliografi. (Disp. 14/10 2011).

23. Hans Leander: Discourses of Empire: The Gospel of Mark from a Postcolonial Perspective. (Disp. 9/12 2011).

24. Helena Dahlberg: Vikten av kropp. Frågan om kött och människa i Maurice Merleau-Pontys Le visible et l'invisible. (Disp. 16/12 2011).

25. Anna Tessmann: The Good Faith: A Fourfold Construction of Zoroastrianism in Russia. (Disp. 16/5 2012).

26. Rosmari Lillas: Hendiadys in the Hebrew Bible. An Investigation of the Applications of the Term. (Disp. 1/6 2012).

27. Mattias Bäckström: Hjärtats härdar-folkliv, folkmuseer och minnesmärken i Skandinavien, 1808-1907. (Disp. 2/6 2012).

28. Sigrid Schottenius Cullhed: Proba the Prophet. Studies in the Christian Virgilian Cento of Faltonia Betitia Proba. (Disp. 30/11 2012).

29. Wilhelm Kardemark: När livet tar rätt form. Om människosyn i svenska hälsotidskrifter 1910-13 och 2009. (Disp. 18/1 2013).

30. Jessica Moberg: Piety, Intimacy and Mobility: A Case Study of Charismatic Christianity in Present-Day Stockholm. (Disp. 15/2 2013).

31. Julia Nordblad: Jämlikhetens villkor: Demos, imperium och pedagogik i Bretagne, Tunisien, Tornedalen och Lappmarken, 1880-1925. (Disp. 26/4 2013).

32. Anne Ross Solberg: The Mahdi Wears Armani: An Analysis of the Harun Tahya Enterprise. (Disp. 13/6 2013).

33. Simon Sorgenfrei: American Dervish: Making Mevlevism in the United States of America. (Disp. 7/6 2013).

34. Cecilia Carlander: Les Figures féminines de la Décadence et leurs implications esthétiques dans quelques romans français et suédois. (Disp. 19/9 2013).

35. Tilda Maria Forselius: God dag, min läsare! Bland berättare, brevskrivare, boktryckare och andra bidragsgivare i tidig svensk veckopress 1730-1773. (Disp. 1/11 2013).

36. Hans Geir Aasmundsen: Pentecostalism, Globalisation and Society in Contemporary Argentina. (Disp. 10/1 2014).

37. Carina Agnesdotter: Dikt i rörelse. Ingrid Sjöstrand och poesins retorik i kvinnornas fredsrörelse 1979-1982. (Disp. 28/2 2014).

38. Robert Azar: Förnuftets auktoritet. Upplysning och legitimitet hos La Motte, Thorild och Kundera. (Disp. 9/5 2014). 
39. Henrik Otterberg: Alma natura, ars severa. Expanses \& Limits of Craft in Henry David Thoreau. (Disp. 21/11 2014).

40. Hjalmar Falk: Det politisk-teologiska komplexet. Fyra kapitel om Carl Schmitts sekularitet. (Disp. 12/12 2014).

41. Ann af Burén: Living Simultaneity: On Religion among Semi-Secular Swedes. (Disp. 23/4 2015).

42. Karolina Enquist Källgren: Subjectivity from exile: place and sign in the works of María Zambrano. (Disp. 22/5 2015).

43. Christoffer Dahl: Litteraturstudiets legitimeringar: analys av skrift och bild i fem läromedel $i$ svenska for gymnasieskolan. (Disp. 30/10 2015).

44. Karin Kittelmann Flensner: Religious Education in Contemporary Pluralistic Sweden. (Disp. $11 / 12$ 2015).

45. Jørgen Thaarup: Kristendommens Morgenstjerne. Konvergerende teologiske trak med baggrund i østlig tradition hos John Wesley og NFS Grundtvig. (Disp. 15/1 2016).

46. Katrin Lilja Waltå: "Äger du en skruvmejsel?" Litteraturstudiets roll i läromedel för gymnasiets yrkesinriktade program under Lpf 94 och Gy 2011. (Disp. 30/9 2016).

47. Christian Giudice: Occultism and Traditionalism: Arturo Reghini and the Anti-Modern Reaction in early Twentieth-Century Italy. (Disp. 28/10 2016).

48. Anton Jansson: Revolution and Revelation: Theology in the Political Thought of Friedrich Julius Stahl, Wilhelm Weitling, and Karl Theodor Welcker. (Disp. 13/1 2017).

49. Peter Carlsson: Teologi som kritik. Graham Ward och den postsekulära hermeneutiken (Disp. 15/9 2017).

50. Patrik Möller: Hemligheternas värld: Bror Gadelius och psykiatrins genombrott $i$ det tidiga 1900-talets Sverige (Disp. 17/11 2017).

51. Anders Pedersson: En fängslande vetenskap?: Kriminologi i Sverige, 1885-1965 (Disp. 24/11 2017).

52. Johan Gardfors: Hodell. Art and Writing in the Neo-Avant-Garde (Disp. 8/12 2017).

53. Mårten Björk: Life Outside Life: The Politics of Immortality, 1914-1945 (Disp 7/9 2018).

54. Giulia Giubergia: The making of martyrs. Uprising, Cultural Sacralization, and Death in Downtown Cairo after 2011 (Disp 9/11 2018).

55. Lisa Schmidt: RADERA: Tippex, tusch, tråd och andra poetiska tekniker (Disp 30/11 2018)

56. Tomas Wedin: The Aporia of Equality: A Historico-Political Approach to Swedish Educational Politics 1946-2000 (Disp 7/12 2018) 